\title{
A Nation + Store Worth Saving: The Silenced Narrative of The Hudson's Bay Company.
}

\author{
by Jagtar Singh
}

A thesis submitted to the Faculty of Graduate and Postdoctoral Affairs in partial fulfillment of the requirements for the degree of Master of Architecture

Carleton University

Ottawa, Ontario

(C) 2015 Jagtar Singh 
"The narrative is how you think of things.' And how you think of things will shape much of what you do or what you want to do or how you understand what you shouldn't do. The single greatest failure of the Canadian experiment, so far, has been our inability to normalize that is, to internalize consciously - the First Nations as the senior founding pillar of our civilization." - Guy Vanderhaeghe.

Fig. 01 (right). Silenced Narrative Postcard Series. See Page 70 for description.

Footnote.

Saul, John Ralston. A Fair Country: Telling Truths About Canada. Toronto, ON: Penguin Canada. 2008. Print. 21.
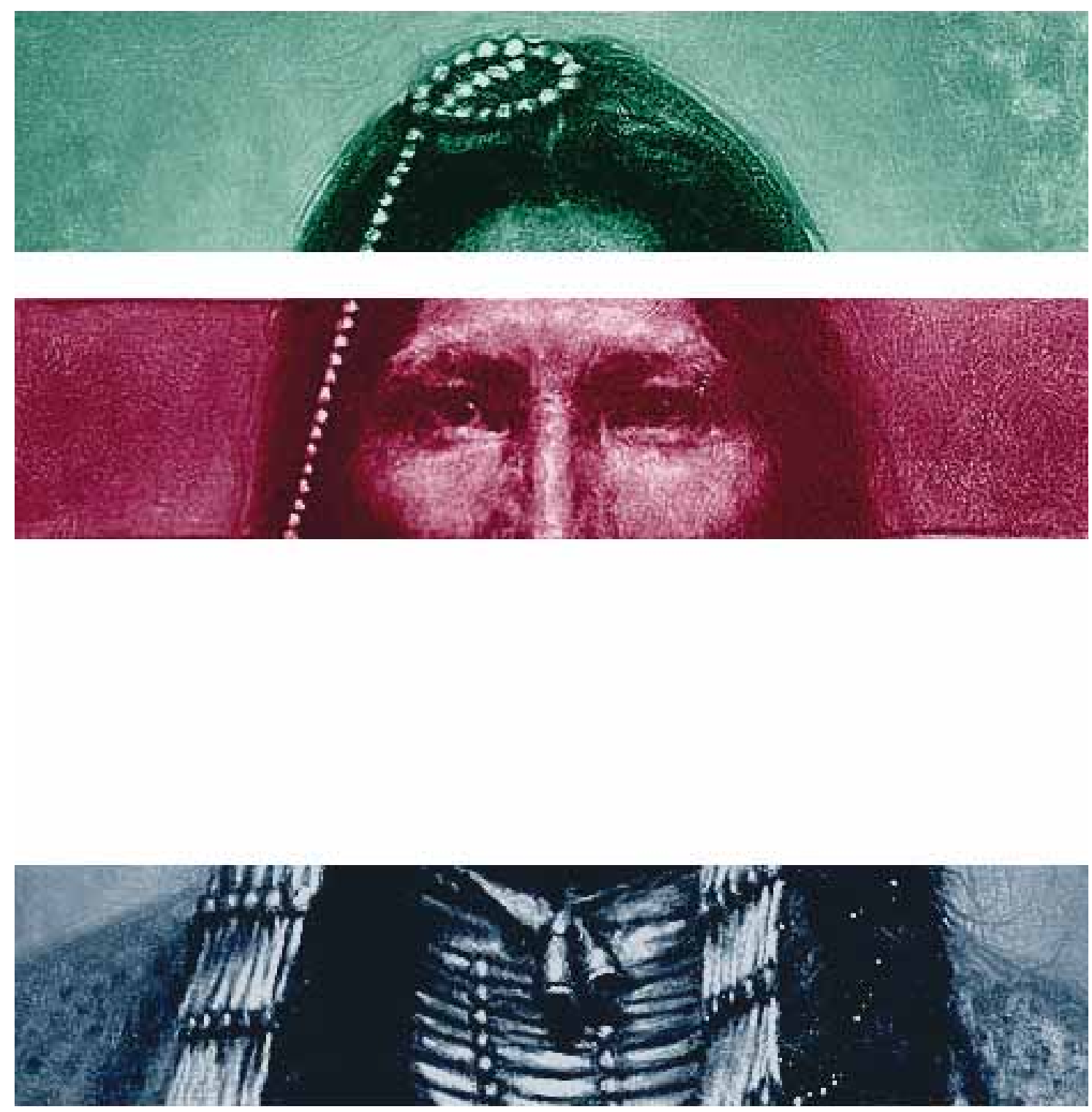



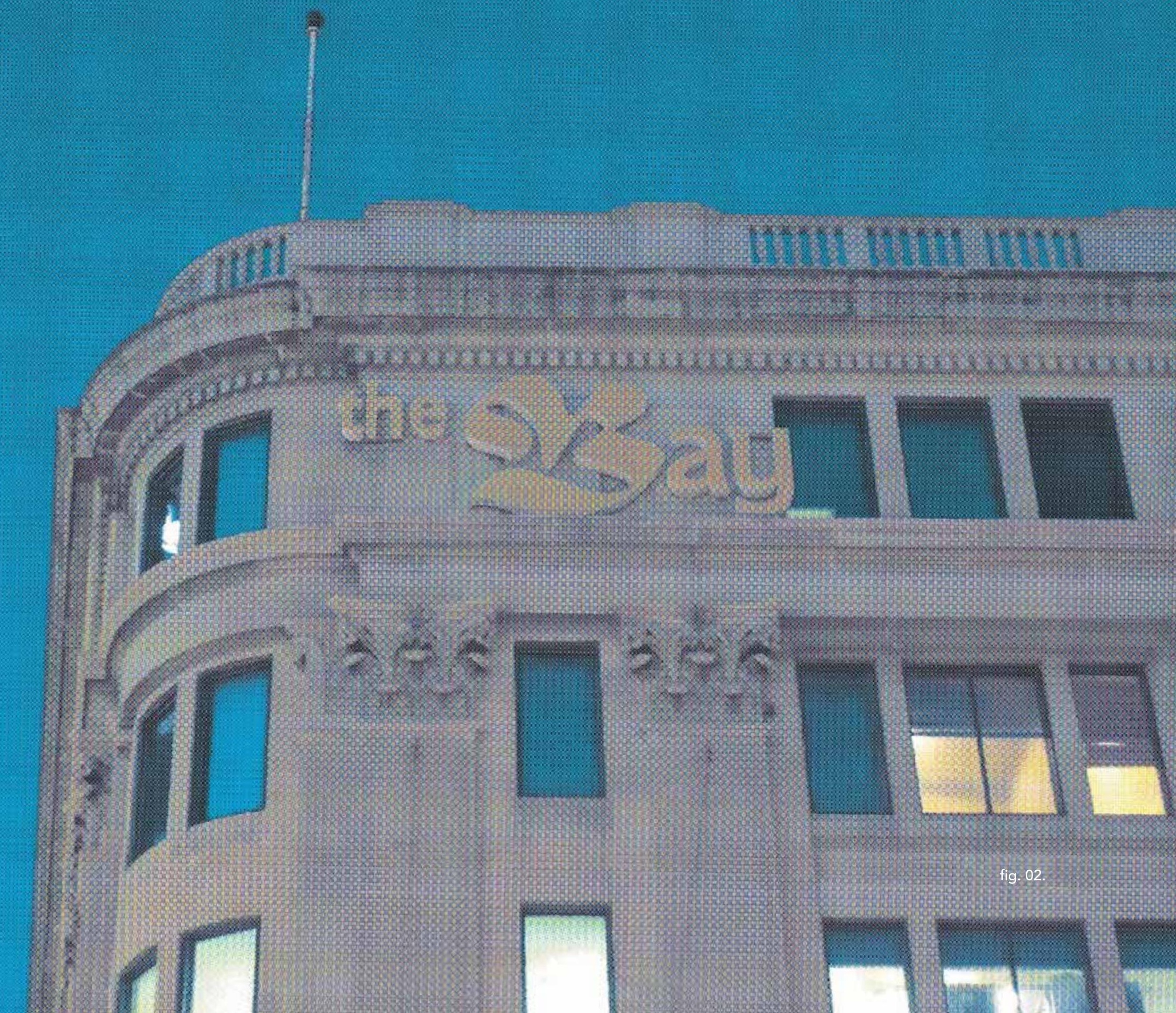




\section{ABSTRACT}

"Founded by Royal Charter in 1670, The Hudson's Bay Company (HBC) is the oldest chartered trading company in the world"1, and has been in continuous operation now for 344 years. Starting off as a fur trade business, the $\mathrm{HBC}$ has now grown to be one of the largest retail empires in North America.

From an early fur trading company, a multitude of trading posts across North America, explorations of the frigid Arctic, the establishment of some prominent western Canadian townships and cities ${ }^{2}$, and to now a thriving retail empire, The HBC has not only played an "instrumental role in the history of Canada and North America" ${ }^{n,}$ but has also become the facet in which many Canadians identify themselves with. The HBC has inevitably played a significant and influential role into both the nation's architectural scene and the city of Winnipeg, Manitoba - their impact is evident across Canada.

The HBC's rich, abundant, and refined history has generally been narrated from none other but their own perspective, often failing to recognize the important and vital roles of their trading partners: the Aboriginal people. The Aboriginal people have a narrative of their own, a bleak and silenced narrative highlighting their struggles, tensions, and setbacks.

By understanding this often overlooked and silenced narrative of the HBC, it will consequently offer and inform new sets of values and beliefs. The focus of these investigations will be the adaptive re-use of The HBC department store in Winnipeg, MB, and how these new values and beliefs could inform a new architecture, giving way to an authentic Canadian identity - making it a Nation + Store Worth Saving. $\infty$ 
Fig. 02. Hudson's Bay Company department store, Portage Avenue

Endnote.
01. Hudson's Bay Company Archives. HBCA Holdings. Website. Accessed Oct. 05, 2014. www.gov.mb.ca/chc/archives/hbca/about/hbca_holdings.
html

02. Historical Atlast of Canada. Website. Explorations from Hudson Bay, 17th to 19th Centuries. Accessed Oct. 09, 2014. www.historicalatlas. ca/website/hacolp/national_perspectives/exploration/UNIT_07/U07 overview.htm

Heritage. Website, Our History: Overview. Accessed Oct. 04, 2014. www.hbcheritage.ca/hbcheritage/history/overview 


\section{ACKNOWLEDGEMENTS}

Anyone who has ever devoted anytime to academic research and the quest for knowledge knows the roller coaster of difficulties that accompany them. These difficulties are lessened by the grateful assistance of others.

On that note, I would like to formally acknowledge the following persons for their contributions from everything to design feedback, references, or a simple encouragement. In no particular order:

Roger Connah, my academic advisor and for making this thesis process as easy as it could get;
Brent Bellamy for the numerous references and topic feedback; external advisors John Cook and Allan Teramura, for their constant constructive input; Manitoba Treaty Commissioner James Wilson and his assistant Darren Courchene, for their insightful interview; as well as Michelle Rydz and Lisa Friesen at The Hudson's Bay Company Archives (HBCA) in Winnipeg for their wealth of knowledge and resources they provided me with; and Monica Ethier at the Wabano Centre for Aboriginal Health in Ottawa.

I would also like to thank fellow architecture colleagues both in Ottawa and back in Winnipeg; to those family and friends who supported me, whether it be an ear to lend, or reassurance I was going to make it to the end. To my partner in crime Mel J. for her relentless encouragement and help those last few weeks; and last but not least, my parents Cora and Terry and sister Diana who gratefully always supported me during my years of academic hardships.

Thank you everyone $\infty$ 



\section{LIST OF ILLUSTRATIONS}

fig. 01. Silenced Narrative Postcard Series.

fig. 02. Hudson's Bay Company department store, Portage Avenue. Winnipeg, MB. Peronal Collection. 2014.

fig. 03. The HBC's The Bay Northern Stores Map. 1670 - 1970. Print.

Personal Photo Collection. 2014

fig. 04. The HBC's Department Store on Portage Ave and Memorial Blvd., in Winnipeg, MB. Personal Photo Collection. 2014

fig. 05. Map of Winnipeg. Unknown. Accessed Jan. 26 2015. http://www.dreamstime.com/stock-photo-mapwinnipeg-canada-manitoba-image42373996

fig. 06. Shooting the Rapids. Frances Anne Hopkins. 1879. National Archives of Canada. C-2774.

Newman, Peter C. Empire of the Bay: An Illustrated History of the Hudson's Bay Company. Toronto, ON Madison Press Books. 1989. p. 111

fig. 07. A Voyage to Hudson's Bay, in Search of the North-West Passage. Litograph Map. 1746-47. Henry Ellis. http://libweb5.princeton.edu/visual_materials/ maps/websites/northwest-passage/moor-smith.htm

fig. 08. The HBC's SS "Dernes" Ship. Section Drawing Onion-skin paper. Photograph. HBC Archives Collection. HBCA s4/iii - G1/397 fig. 09. How to Make a Beaver Hat. Ronald Searle. Drawing. The Great Fur Opera: Animals of the Hudson's Bay Company 1670 - 1970. Toronto, ON: McClelland and Stewart Limited. 1970.

fig. 10. Clearing the Plains: Disease, Politics of Starvation, and the Loss of Aboriginal Life, by James Daschuk Book cover. Photo. Personal Collection. 2014.

fig. 11. Queen Elizabeth II visiting the Indians of Canada Pavillion. Expo 67. Montreal, QC. 1967 Retrieved from http://4.bp.blogspot.com/-5VIGxiP3tA8/ UTaGnqrgyBI/AAAAAAAAKI8/_IoLKL0Z8xs/s1600/ The+Queen+at+Expo.bmp

fig. 12. A Fair Country: Telling Truths About Canada, by John R. Saul. Book cover. Photo. Personal Collection. 2014.

fig. 13. Group of Crees on Plains. Photograph. Unknown. 1916. Retrieved from http://en.wikipedia.org/wiki/ Bureau_of_American_Ethnology

fig. 14. North American Beaver. Photograph. Josh Nagel. Retrieved from http://www.joshnagel.com/?p=936

fig. 15. Indians at HBC Trading Post in 1800s. Engraving Unknown. Getty Images. Retrived from http://www. gettyimages.com.au/detail/news-photo/colorizedengraving-shows-activity-at-a-hudsons-bay-companynews-photo/71630687 
fig. 16. Native People's Trade Fair held at the Bay, Winnipeg. June 25 - July 6 to help commemorate 300th anniversary. Man in centre is C.E. Potter, Sales Promotion (Advertising) Manager. Photograph. HBC Archives. HBCA 1987/363-W-316/377

fig. 17. "Potlatch at Fort Rupert. Piles of Hudson's Bay 'Point' Blankets are being counted out for giving away. Haida canoes are drawn up on the beach." 1890 Photograph. H.I. Smight. Images retrived from HBC Archives. HBCA 1987/363-W-114/6.

fig. 18. Women and children left behind at HBC camps. Photograph. Unknown. Image retrived from http://www. fnha.ca/wellness/our-history-our-health

fig. 19. The blackboard on the left reads: "Thou Shalt Not Tell Lies." Cree students at the Anglican-run Lac la Ronge Mission School in Saskatchewan in 1945. Photograph. Archives and Library Canada. Image retrived from http://www.huffingtonpost.ca/charlieangus/residential-school-st-annes_b_4166741.htm

fig. 20. Arrival of P.E. Radisson at an Indian Camp in 1800s. Engraving. Unknown. Getty Images. Retrived from http://en.wikipedia.org/wiki/Coureur_des_bois

fig. 21. Identity Theft. Dana Claxton. Photograph. Image retrieved from http://www.straight.com/arts/danaclaxtons-new-interdisciplinary-work-cultural-mashup

fig. 22. Young girl on a Northern Aboriginal Reserve. Despite popular belief, many northern communities lack proper schools and resources to educate their yourth. Photograph. Bernard Weil. Toronto Star. Image retrieved from http://www.macleans.ca/news/canada/ out-of-sight-out-of-mind-2/ fig. 23. IEthnomusicologist Frances Densmore recording Blackfoot chief Mountain Chief. Photograph. 1916. Image retrieved from http://en.wikipedia.org/wiki/ Bureau_of_American_Ethnology

fig. 24. Nurses feed Aboriginal children at the Charles Camsell Indian Hospital. Experiments were conducted on Aboriginals to test the effectiveness of streptomycin in combating tuberculosis. Photograph. October 1958. Image retrieved from http://sciencewriters. $\mathrm{ca} / 2013 / 10 / 30 /$ meet-ian-mosby-the-man-whoexposed-canadas-experiments-on-aboriginals/

fig. 25. Indians of Canada Pavillion. Montreal, QC. 1967 mage retrieved from http://upload.wikimedia.org/ wikipedia/commons/c/cd/Expo_67\%2C_pavillon_Les_ Indiens_du_Canada_\%282\%29.jpg

fig. 26. The HBC's Department Store on Portage Avenue and Vaughan Street. Winnipeg, MB. Personal photo collection. 2014.

fig. 27. 1884 Map of Winnipeg and St. Boniface. Thomas. R Weir. 1912. Print. Atlas of Winnipeg. Toronto, ON: University of Toronto Press. 1978.

fig. 28. 1884 Map of Winnipeg and St. Boniface. Thomas. R Weir. 1912. Print. Atlas of Winnipeg. Toronto, ON: University of Toronto Press. 1978.

fig. 29. Métis political leader Louis Riel. Photograph. Baldwin. 1878. University of Manitoba Library Archives. PC 107.

fig. 30. Reaction in Ontario to Scott's execution. Photograph. A History of Manitoba: Volume One - Rupert's Land to Riel. Winnipeg, MB: Great Plains Publications, Ltd. 1993. fig. 31. The HBC Winnipeg department store Photograph. HBC Archives Collection. HBCA 1987/363W-315/82

fig. 32. 1887 Map showing area of HBC Reserve. Site of the Forks. Winnipeg, MB. E-000007937 Library and Archives Canada

fig. 33. The HBC Victoria department store. 1921 Photograph. HBC Archives Collection.

HBCA 1987/363-V-25/9

fig. 34. The HBC Vancouver department store. 1914 Photograph. HBC Archives Collection.

HBCA 1987/363-V-115/10

fig. 35. The HBC Calgary department store. 1913 Photograph. HBC Archives Collection. HBCA 1987/363 C-213/11

fig. 36. The HBC Edmonton department store

1913. Photograph. http://www.hbcheritage.ca/ hbcheritage/history/timeline/early/home

fig. 37. (previous page) The HBC's Department Store. Main Retail Floor, 1950. Winnipeg, MB. Photograph. HBC Archives Collection. HBCA 1987/363-W-316/108

fig. 38 (previous page). The Mall of Triumph grand master plan. Drawing. Unknown. Image retrived from http://www.winnipegfreepress.com/city-beautiful/ City-Beautiful---Part-1-Great-Expectations-273837201. html?cx_navSource=d-spotlight

fig. 39. The HBC's Department Store Under construction. 1925-26. Portage Ave \& Colony St. Winnipeg, MB. Photograph. HBC Archives Collection. HBCA 1987/363 W-315/36 
fig. 40. The Capitol Approach to the $\$ 3,000,000$ Parliament Building. Manitoba Free Press. Winnipeg, MB. Sep. 30, 1913. Image retrived from http://www. winnipegfreepress.com/city-beautiful/City-Beautiful--Part-1-Great-Expectations-273837201.html?cx navSource $=d$-spotlight

fig. 41. The HBC's Department Store enourmous elevator mural by A.Sherriff Scott and E.T. Adney Winnipeg, MB. Photograph. HBC Archives Collection. HBCA 1987/363-W-316/20B

fig. 42. The Hudson's Bay Company's Point Blanket. Illustration. The Beaver magazine cover. Imaged retrieved from http://www.patrimoinehbc.ca/ hbcheritage/pictures/annonces-imprimees

fig. $43 \& 44$ (previous pages). The HBC's Department Store along Memorial Avenue. In figure 44, the Manitoba Legislative Building can be seen. Winnipeg, MB. Personal photo collection. 2014

fig. $45,46, \& 47$. The current state of HBC's Department Store. Portions of the building have been closed off to public, in conjuction to the large open spaces that are indicative of both the building's physical and economical decline. Winnipeg, MB. Personal photo collection. 2014

fig. 48. (previous page) Fox and Fiddle Pub takes up an old Toronto Dominion Bank building. Exchange Distric along Main Street. Winnipeg, MB. Photograph. Personal Collection. 2012

fig. 49. 1875 Map of Winnipeg, two years after the city was Incorporated. Thomas. R Weir. 1912. Print. Atlas of Winnipeg. Toronto, ON: University of Toronto Press. 1978. fig. 50. Map depicting Winnipeg as 'Center of North America'. Thomas. R Weir. Print. Atlas of Winnipeg. Toronto, ON: University of Toronto Press. 1978.

fig. 51. City Hall and Union Bank, with Leland Hotel. Winnipeg, MB. Postcard. of Winnipeg (Consolidated Stationery Company (C.S.Co) in Winnipeg. 1907

fig. 52. White Star Diner on Albert Street. The Exchange District. Winnipeg, MB. Personal photo collection. 2011.

fig. 53. Canadian National Human Rights Museum. The Forks, Winnipeg, MB Photograph. Josel Catindoy. 2014 http://www.acec.ca/events__awards/acec_summit_ and_national_convention/2013/summit2014.htm

fig. 54. Canada's Race Problem. Maclean's Magazine Cover. Feb. 02, 2015. Image retrieved from http://www. macleans.ca/news/canada/cover-preview-canadas-raceproblem/

fig. 54. Canada's Race Problem. Maclean's Magazine Cover. Feb. 02, 2015. Image retrieved from http://www. macleans.ca/news/canada/cover-preview-canadas-raceproblem/

fig. 55. Manitoba Treaty Commissioner Jamie Wilson, along side other high officials at Winnipeg's City Hall. The press conference was held by city mayor Brian Bowman, city officials, and Aboriginal leaders in response to Maclean's Magazine article Canada Has Bigger Race Problem than America. And it's Ugliest in Winnipeg. Feb. 2015. Image retrieved from http://www. macleans.ca/news/canada/for-the-record-winnipegspolitical-leaders-condemn-racism/

fig. 56. Image retrieved from http://www.macleans.ca/ news/canada/out-of-sight-out-of-mind-2/ fig. 57. Utah Sky reflection on the lake. Photograph Bill Hobbs. Image retrieved from http://billhobbs.com/ utah-sky/\#sthash.5RR6xT5X.dpbs.

fig. 58. Current state of the near abandoned Second floor of The HBC department store. Winnipeg, MB. Photograph. Personal Collection. 2014.

fig. 59. View of Treaty Day ceremonies from the gallery in Province House. Halifax, Nova Scotia. Photograph. Unknown. Oct. 03, 2011. Image retrived from http:// novascotia.ca/news/smr/2011-10-03-Treaty-Day/

fig. 60. City Map of Winnipeg, MB.

fig. 61. Site Plan of Memorial Blvd.

fig. 62. The HBC Store Site Plan.

fig. 63. The HBC Parkade Site Plan

fig. 64. Proposed Plan.

fig. 65. Aboriginal Embassy Memorial Garden Render.

fig. 66. Aboriginal Embassy Front Elevation.

fig. 67. Aboriginal Embassy Memorial Blvd. Elevation.

fig. 68. Aboriginal Embassy Vaughan St. Elevation.

fig. 69. Aboriginal Embassy Memorial Garden/Parkade Section.

fig. 70. Embassy Facade Render.

fig. 71. Aboriginal Embassy Lobby/Entrance Render.

fig. 72. Aboriginal Embassy Section. 
fig. 73. Aboriginal Embassy Representational Section

fig. 74. Aboriginal Embassy 2nd Floor Plan.

fig. 75. Aboriginal Embassy Sun Atrium Render.

fig. 76. Aboriginal Embassy Exploded Axo Program.

fig. 77. Aboriginal Embassy Exploded Axo Circulation.

fig. 78. Aboriginal Embassy 3rd Floor Plan.

fig. 79. Aboriginal Embassy 4th Floor Plan.

Appendix 1 - Conversations with the Commissioner: Complete Transcript. Part 1

Appendix 2 - Conversations with the Commissioner: Complete Transcript. Part 2

Appendix 3 - Conversations with the Commissioner:

Complete Transcript. Part 3 fig. 80. Aboriginal Embassy 5th Floor Plan.

fig. 81. Aboriginal Embassy 6th Floor Plan.

fig. 82. Aboriginal Embassy Parkade.

fig. 83. Aboriginal Embassy Red Band.

fig. 84 to 123. The HBC's Department Store under construction in 1925. Winnipeg, MB. HBC Archives.

Photo Series HBCA 1987/363-W-315/1 - 60

\section{LIST OF APPENDICES}


Table of Contents

ABSTRACT $V$
ACKNOWLEDGMENTS VII

LIST OF TABLES IX

LIST OF ILLUSTRATIONS IX

LIST OF APPENDICES XII

INTRODUCTION 16

THESIS + NARRATIVE MAPPING 19

TIME LINE 22

The Narrative. Part One

$\begin{array}{rr}\text { Brief History: The Hudson's Bay Company } & 28 \\ \text { Silenced History: An Aboriginal Narrative } & 37 \\ \text { Identity + Loss: Conversations with the Commissioner } & 57 \\ \text { SILENCED NARRATIVE: POST CARDS } & 69\end{array}$


The Site. Part Two

The Hudson's Bay Company in Winnipeg + Manitoba 78

The Hudson's Bay Company: The Department Store 92

The Architecture. Part Three

Winnipeg's Current Situation: the Good, the Bad... 109

and the Ugly: an Architectural Intervention 122

Project Portfolio: an Aboriginal Embassy 131

$\begin{array}{rr}\text { APPENDIX } & 174 \\ \text { POST-SCRIPT } & 205 \\ \text { BIBLIOGRAPHY } & 210\end{array}$




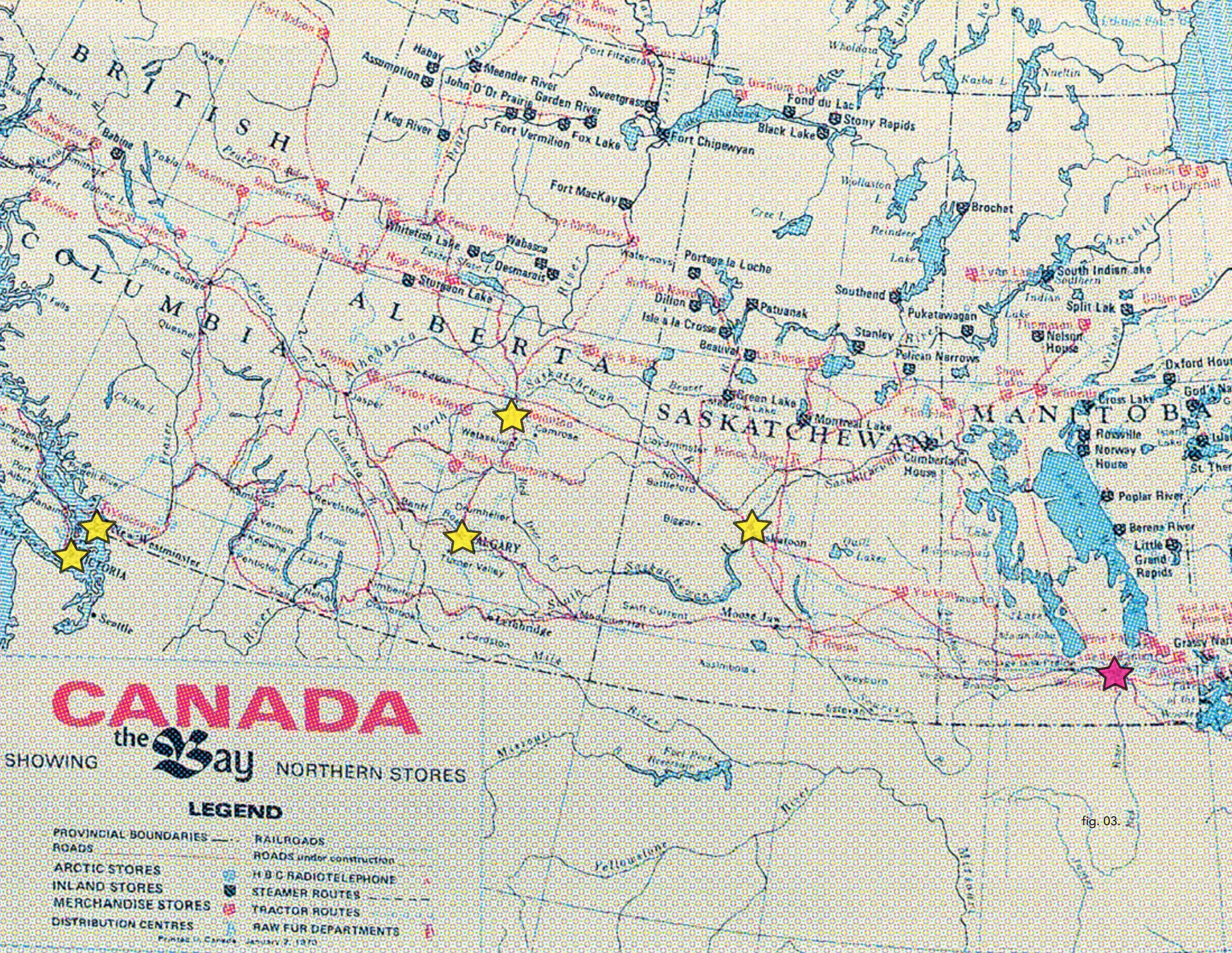




\section{INTRODUCTION}

When we think of Canadian icons that resonate throughout the country's existence, we often think of Maple syrup, ice hockey, snowstorms, and the "hardworking beaver"1. So how has it then, that this humble beaver has become so synonymous with Canadian culture and its heritage? We can attribute Canada's strong ties to the beaver because of The Hudson's Bay Company (HBC) - where a beaver's pelt was once regarded as an important form of currency for both Aboriginals and first European settlers ${ }^{2}$.

For many Canadians, their first engagement with The HBC started off with a visit to one of its stores. Just prior, and shortly after World War I (late 19th and early 20th century), the HBC had setup a considerable number of general and department stores, as well as trading outposts across what is now Canada.

Their department stores ushered in a new type of modernized life, where plentiful of goods and services were provided under the convenience of one roof. As stated by Graydon Carter of Assouline Publishing, the stores" arrivals "were as symbolic of a city's arrival as sports arenas are now. The stores themselves were massive Edwardian temples" ${ }^{3}$, and it was cities like Winnipeg, Saskatoon, Edmonton, Calgary, Vancouver, and Victoria that would first reap their benefits. In conjunction with the rail lines that ran through these cities ${ }^{3}$, these townships - at that time would experience an exponential growth, eventually leading to the development of their respective cities.

What allows the $\mathrm{HBC}$ to be such a credible icon and a historical lineage to Canada is its rich narrative, but also its abundant contribution to the nation's exploration and development.

The HBC's history is deeply rooted, if not, a precursor to Canada's 


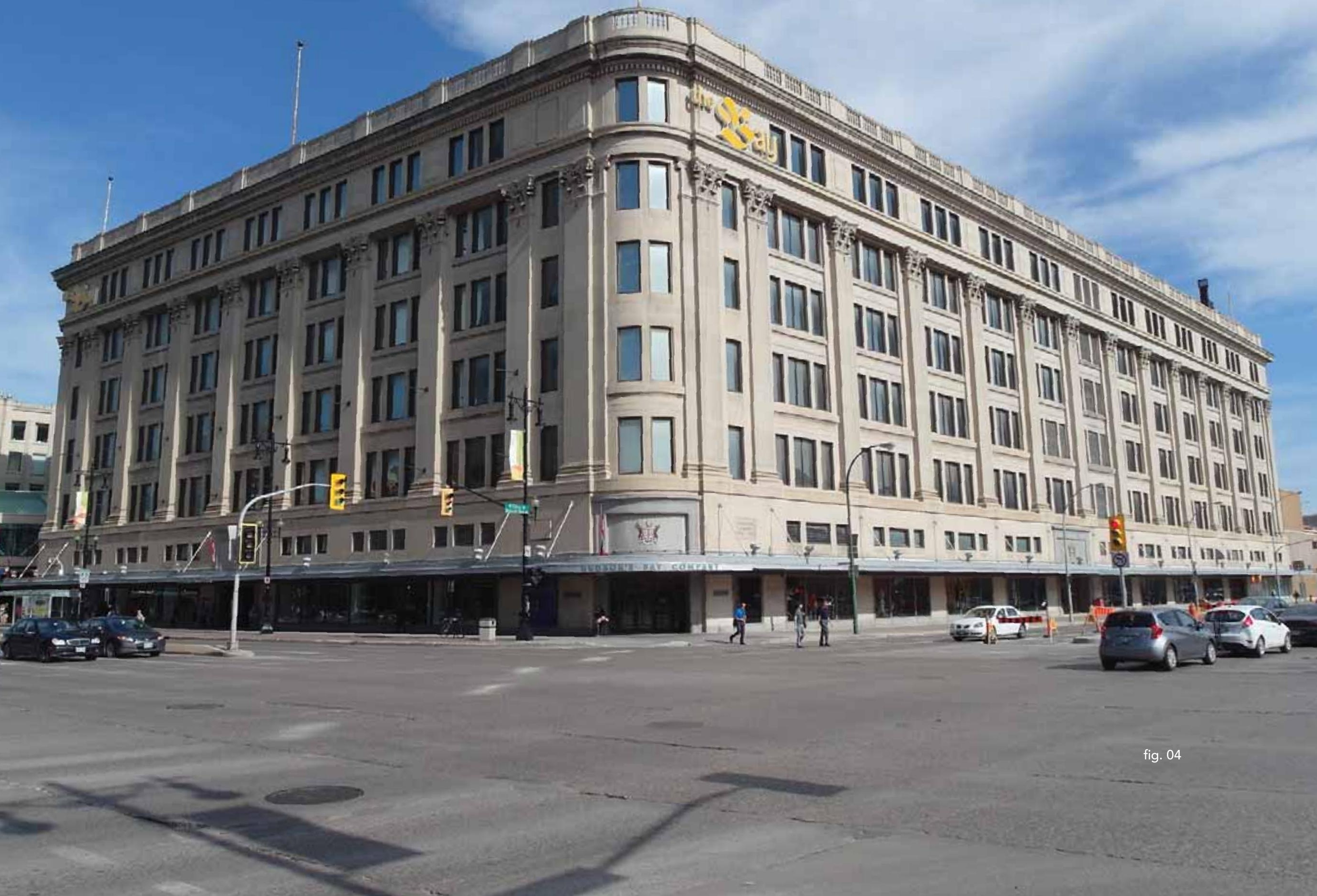


history - depending on which point of view one is given, or led to believe. Generally, the company's history has been narrated from none other but their own perspective, often failing to recognize the important and vital roles of their trading partners: the Aboriginal people. Inundated with important and influential British and French monarchies, explorers, and settlers, the HBC narrative gives little to no credit to the Aboriginal people who were well receptive of the newcomers, with their narrative often negating or silencing the Aboriginal's contributions to their success.

The Aboriginal people have a narrative of their own - considered bleak and often neglected - this narrative highlighting their struggles, tensions, and setbacks. Controversial, and often denouncing the "historical and contemporary abuses of the Canadian government" ${ }^{4}$, the Aboriginal narrative is rarely given an opportunity to speak, yet alone be heard without discrimination. Their narrative is the precursor to the precursor, Canada's history before it was a British-Canadiana, yet their narrative is not one that is commonly considered by many Canadian, or perhaps even suitable.

These studies are not

intended to summarize, nor dilute the Aboriginal people's narrative of
Canada or their struggles; instead the aim is to generate an understanding of their censored history. By understanding this overlooked and silenced narrative of The HBC voiced by the Aboriginal people, it will set out to offer and inform some considerable new sets of values and beliefs. $\infty$

fig. 03. The HBC's The Bay Northern Stores Map. 1670 - 1970. Print. Personal Photo Collection. 2014.

fig. 04. The HBC's Department Store on Portage Ave. and Memorial Blvd, in Winnipeg, MB. Personal Photo Collection. 2014.

Endnotes

01. Carter, Graydon. Hudson's Bay Company. New York. NY: Assouline Publishing. 2011. Print. p. 145

02. Ibid. 100

03. Ibid. p. 4

04. Capela-Labourde, Cécile. The Indians of Canada Pavilion at Expo 67: An Expression of Colonialism. Montréal, QC: McGill University. March 29, 2010. Print. p.3 


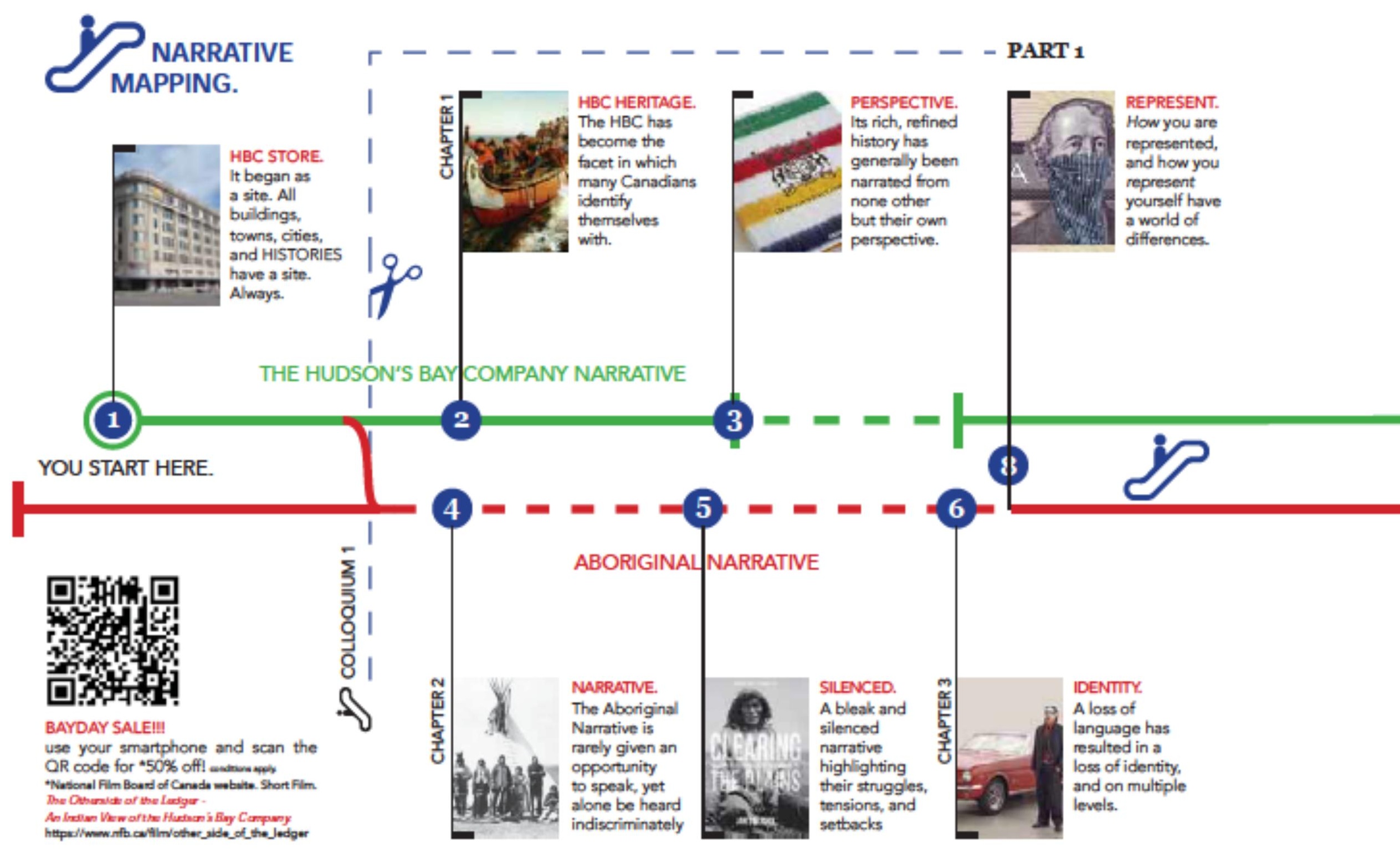




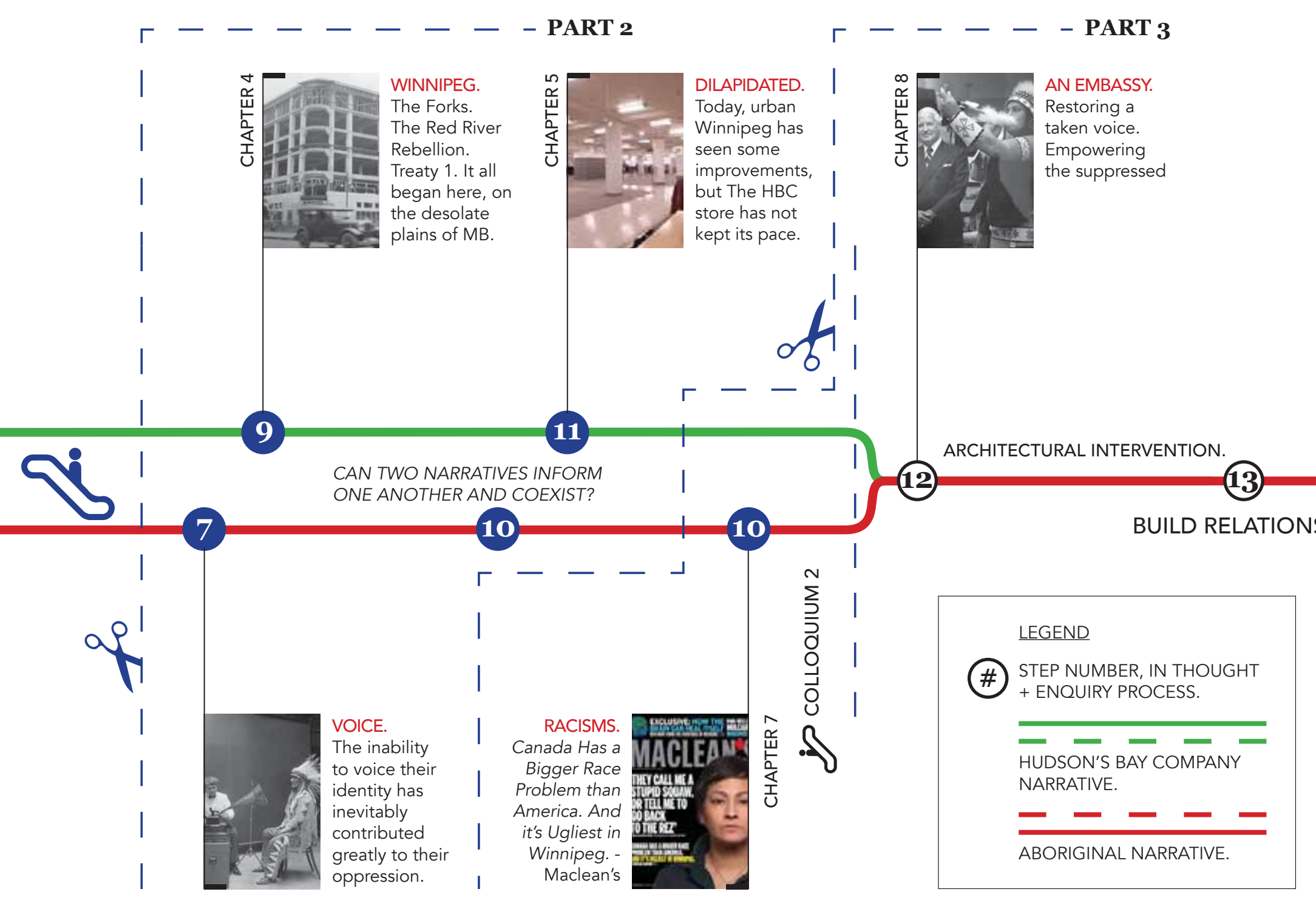




\section{Hothom}

\%

$+0^{+\infty}$

$30 \%$

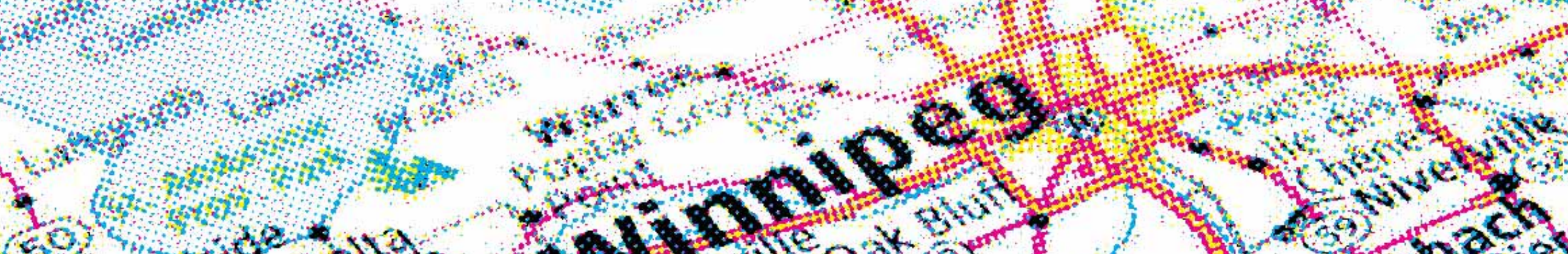

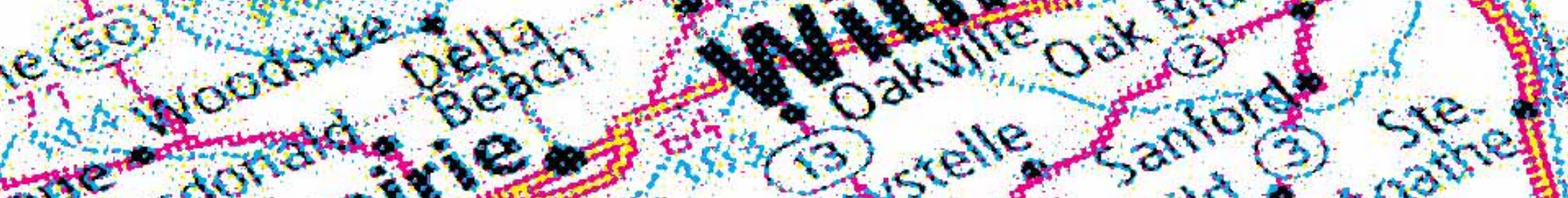

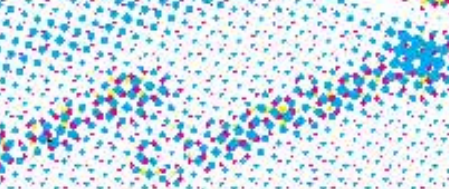

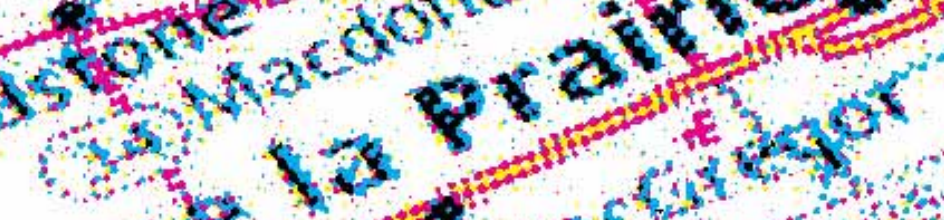

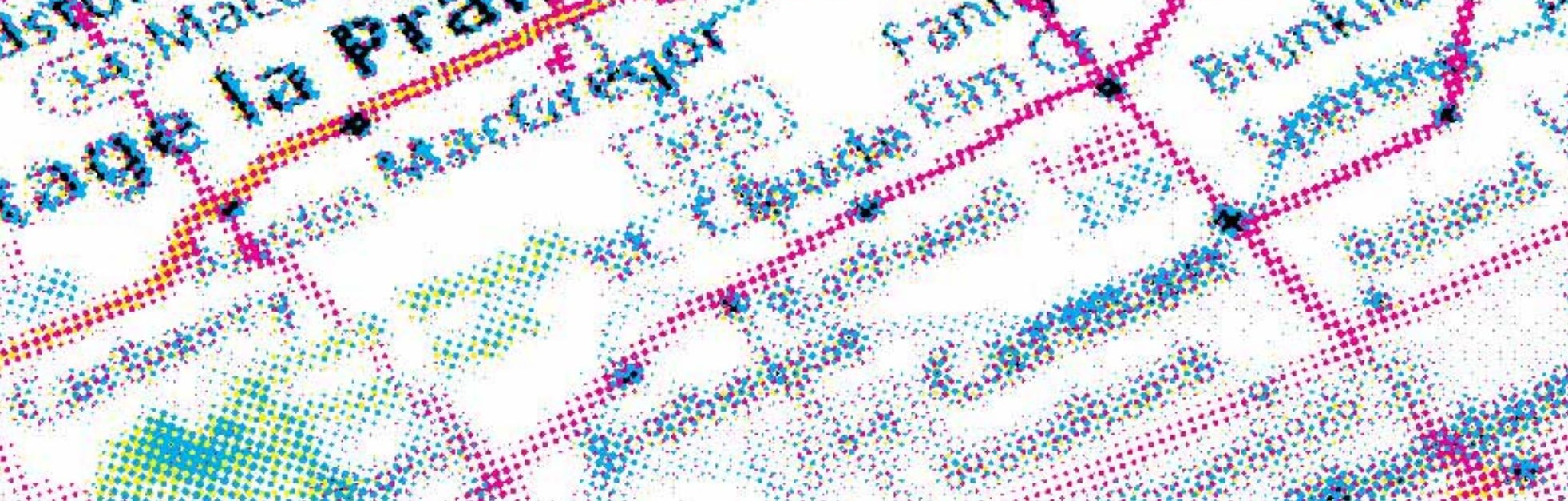

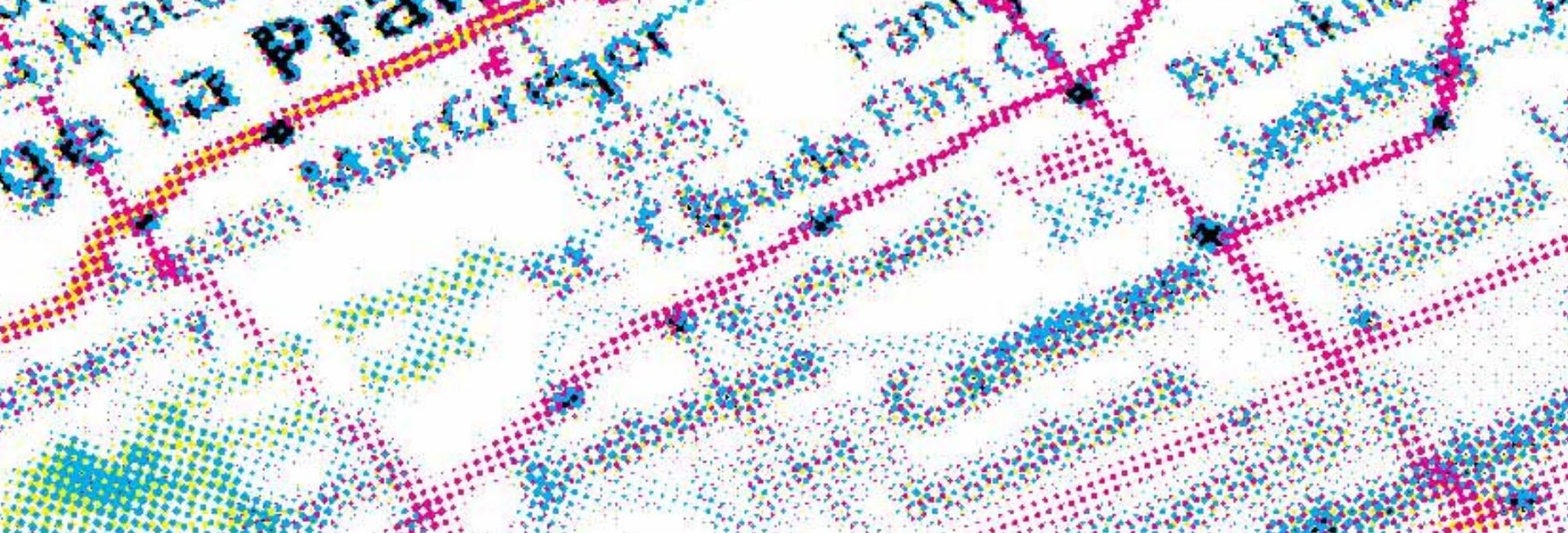

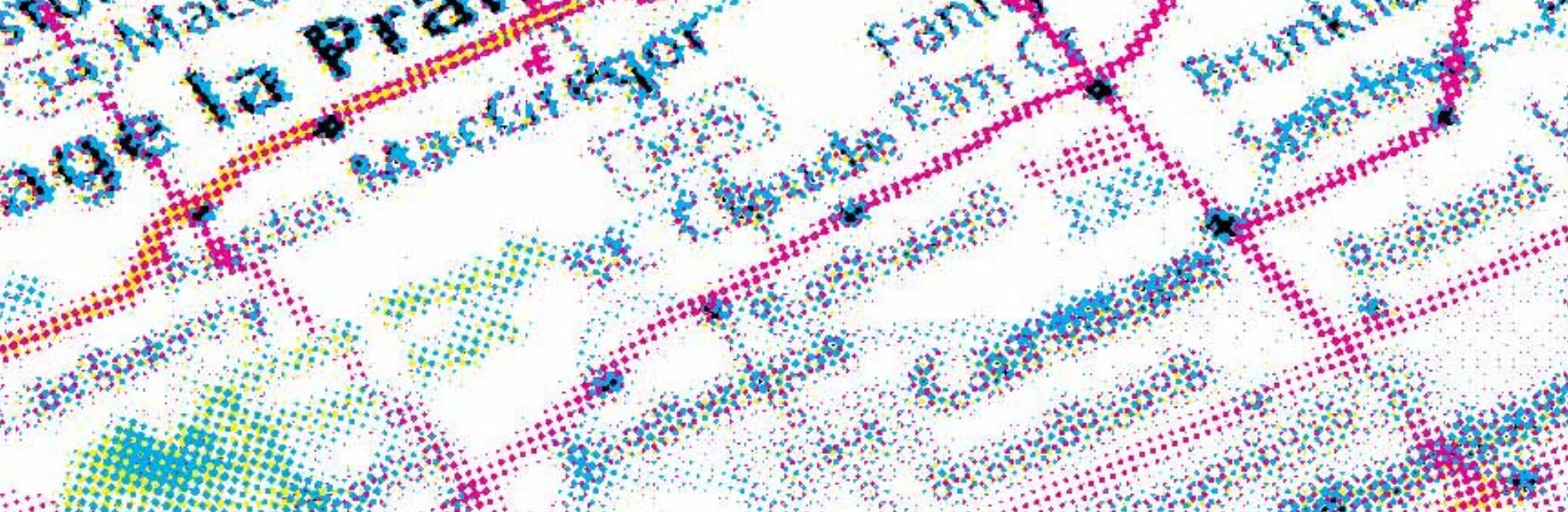

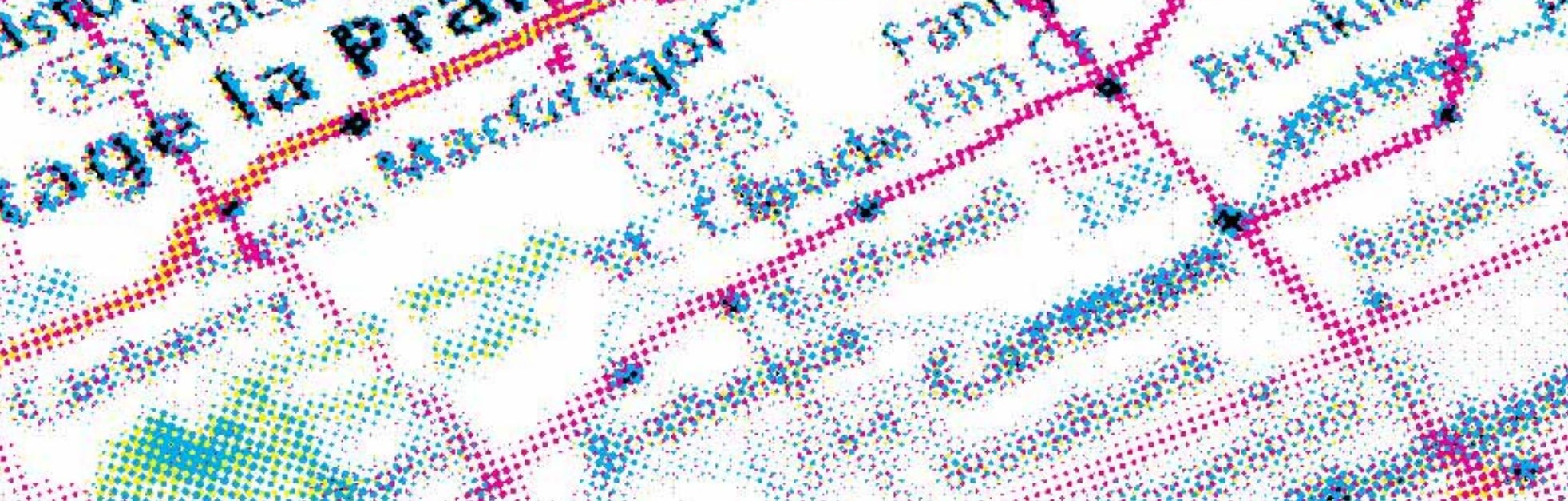

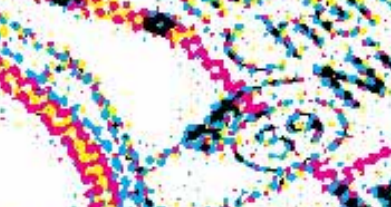
26

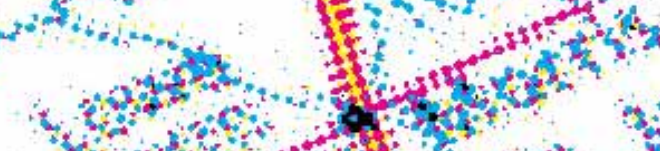
sit 


\section{TIME LINE:}

\section{City of Winnipeg and The Hudson's Bay Company.}

\section{0 - King Charles II}

grants a charter to The Hudsons'

Bay Company. This resulted in the greater portion of the Dominion of Canada to be under the possession of The Hudson's Bay Company; until 1869 when the company voluntarily handed their territory over to what is now Canada.

1738 - Fort Rouge trading post established.

1822 - Fort Garry - formerly named Fort Gibraltar - established by the Hudson's Bay Company.

1855 - February 28, first post office opens in Western Canada.

1869 - The Hudson's Bay Company transfers its land deeds over to the Dominion of Canada.

1869 - Political leader Louis Riel and supporting Métis people begin a revolt.

1870 - March 4, Louis Riel orders the shoothing execution of his opponent Thomas Scott.
1870 - Louis Riel flees to the United States after Colonel Garnet Wolseley and his military reaches Fort Garry. Métis revolt also comes.

1870 - Province of Manitoba formed, becoming the 5 th province in the Dominion of Canada.

1876 - First City hall and Theatre constructed in Winnipeg.

1877 - University of Manitoba established.

1878 - First railway service between Winnipeg and St. Paul, Minnesota. 
1878 - First telephone introduced to the city.

1885 - Louis Riel is hanged for his leadership in two Métis revolts, and the 1870 shooting of Thomas Scott.

1881 - The Hudson's Bay

Company establishes its first General

Store on Main Street.

1886 - First railway trip completed from Montreal, QC to Vancouver, BC.

Company presents the city of
- The Hudson's Bay
Winnipeg with the Fort Garry
Gateway.

1912 - Provincial boundary of

Manitoba extended all the way to the Hudson Bay.

1919 - May 15 to June 26. Winnipeg General Strike, a major movement in the recognition of unions and collective bargaining in Canada.

1920 - First Civic election held.

1924 - 50th anniversary of the Incorporation of the City of Winnipeg.

1925 - Manitoba Provincial Legislative building constructed.

1925 - The Hudson's Bay

Company sets forth to build their flagship 7-floor department store in line to the Provincial Legislative building, construction of the destore was completed in 1926.

1930 - Diamond Jubilee celebration of Manitoba's formation as province, and inclusion in the Dominion of Canada.

1939 - First official visit from King George IV and Queen Elizabeth.

1950 - River levels reach 30.3 feet above city's datum line, highest in 89 years, resulting in the construction of the Floodway system. 
1952 - Construction of the Floodway system is completed - Up to 30 feet of water protection areas throughout the city.

1968 - Second phase of Red River Floodway system is completed.

1975 - January 11. 23.0 hour blizzard with snowfall of $12.2 \mathrm{~cm}$, and wind speeds of $66 \mathrm{~km} / \mathrm{h}$.

1976 - Official opening of the Royal Canadian Mint.

1981 - City of Winnipeg initiates a $\$ 96$ million revitalization plan, in attempts to revitalize its economic, social, and physical urban downtown core; all three levels of government are involved.

1986 - Winnipeg Core Area Initiative extended for 5-years, and \$100 million.

1987 - North Portage development plan, which includes a shopping mall, pedestrian walkway around Portage Avenue, and apartment buildings.

1988 - 1.2 miles of continuous weather-covered pedestrian walkway is completed, linking The $\mathrm{HBC}$ Department Store to Winnipeg Square at Main St.
1989 - October 4. Official opening of The Forks Market.

1994 - City of Winnipeg passes City by-law requiring municipal services to be available in both English and French.

1995 - June. City receives week of record-high temperatures of +38.8 degrees Celsius, breaking records from 1888 and 1931.

1997 - April 5 - 6. Worst recorded blizzard of century with snowfall of $48 \mathrm{~cm}$ over 5 -day period. 
1997 - Manitoba's "Flood of the

Century", many rural communities

severely flooded, yet Winnipeg's

impact is minimal due to its

constructed Floodway system.

2002 - July 25 - August 4. Winnipeg

hosts the North American Indigenous

Games. $\infty$

fig. 05. Map of Winnipeg. Unknown. Accessed Jan. 26, 2015. http:// www.dreamstime.com/stock-photo-map-winnipeg-canada-manitobaimage42373996

The City of Winnipeg. Website. Timeline of Winnipeg Historical Events

1670 - 2012. Accessed Dec. 21, 2014. http://www.winnipeg.ca/services/

CityLife/HistoryOfWinnipeg/HistoricalDates.stm 
The Narrative. Part One

Brief History: The Hudson's Bay Company

Silenced History: An Aboriginal Narrative 37

Identity + Loss: Conversations with the Commissionaire 


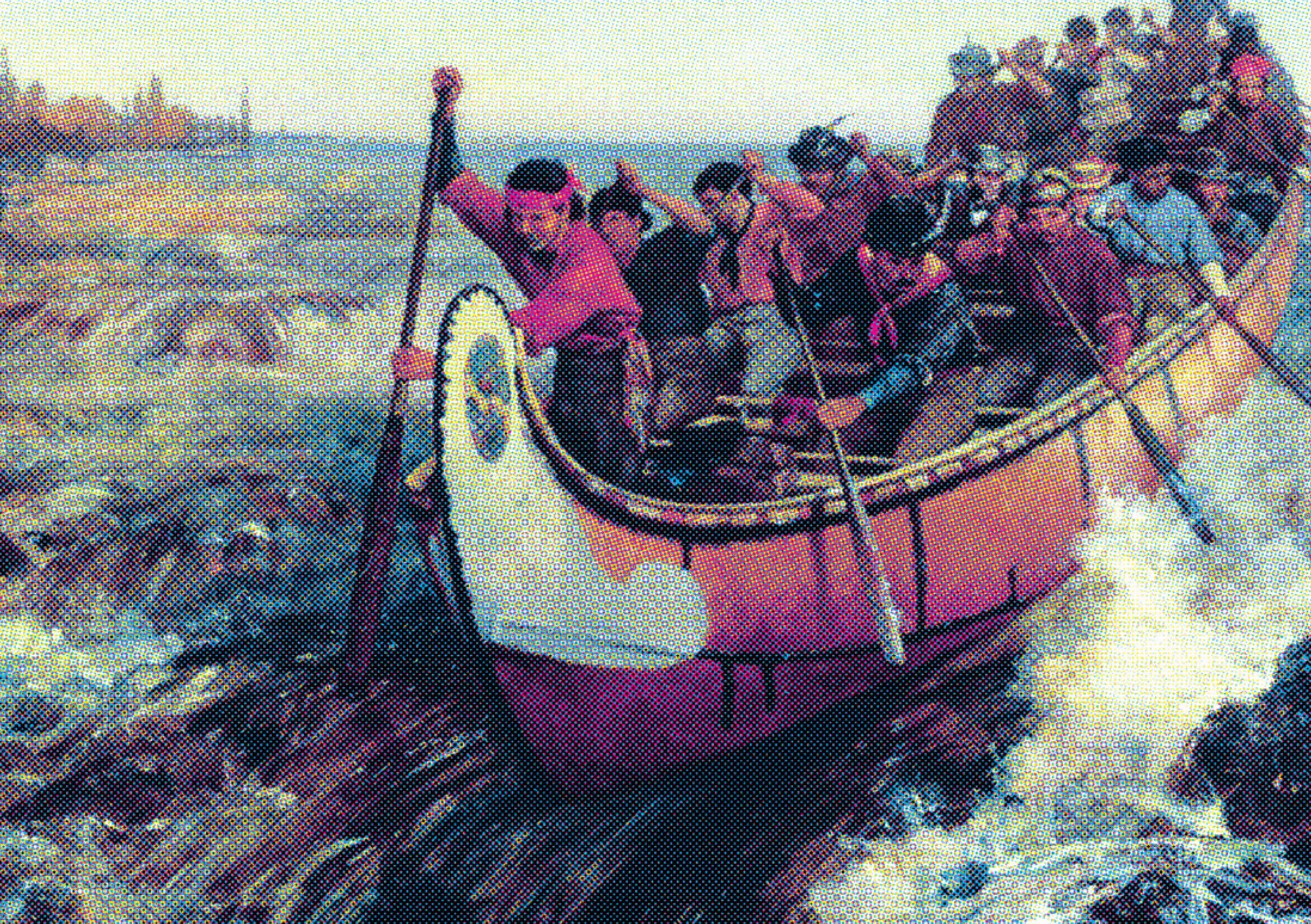


CHAPTER 1 "Founded by Royal Charter in 1670, the Hudson's Bay Company (HBC) is the Brief History: $\quad$ oldest chartered trading company in the world", and has been in continuous

The Hudson’s Bay Company operation now for 344 years. Starting off as a fur trade business, the Hudson's Bay has now grown to be one of the largest retail empires in North America.

Understanding the Hudson's Bay Company's (HBC) role and impact on Canada starts nothing less than a crash course in NewWorld British history. Dating back to nearly three-and-a-half centuries ago, The HBC has had a presence on both Canadian, and American soils. Helping to define Canada's political geography, the "Company's history is inextricably woven with that of the country." 2

fig. 06. (previous page). Shooting the Rapids. Frances Anne Hopkins. Newman Peter C. Empire of the Bay An Illutat

trated History of the Hudson's Bay Company. Toronto, ON: Madison Press Books. 1989. p. 111
How is it then that a fur trade business eventually translated into a nation? And more importantly, what does The HBC signify to Canadians today?

In the late 16th century, English explorers would set sail from Europe seeking a faster passageway between Europe and the Orient - which would become known as the Northwest Passage - but were unsuccessful in finding a direct route at the time. It was later in 1610 that an English explorer named Henry Hudson would take on the task of 
finding this folkloric route, but would eventually navigate his way to what is now known as Hudson's Bay. Though unsuccessful at finding a direct route to Asia, what was evident was the abundance of fur-bearing animals in the bay region. ${ }^{3}$

Decades later in 1659 , a pair of French fur traders named Pierre-Esprit Radisson along with his brother in law Médard Chouart, Sieur de Groseilliers, would embark on a voyage to North America seeking out new fur trade opportunities. Unable to obtain the support from their French government, or that from New Englanders, the pair turned to the British for support. ${ }^{5}$ The pair returned

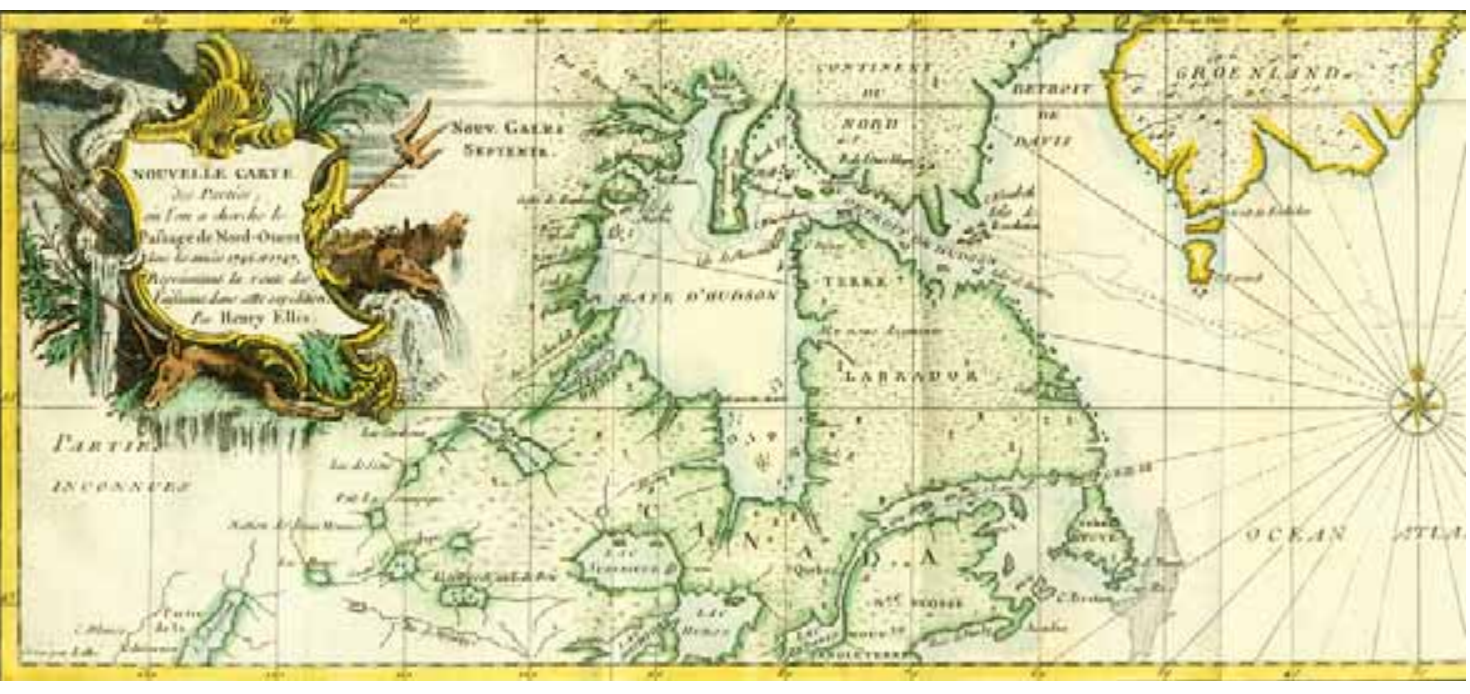

fig. 07. A Voyage to Hudson's Bay, in Search of the North-West Passage. Litograph Map. 1746-47. Henry Ellis. http:// libweb5.princeton.edu/visual_materials/maps/websites/northwest-passage/moor-smith.htm

to Europe with the knowledge of which regions contained an abundance of furs - information they obtained with the assistance of the Cree Aboriginals - and were promptly introduced to the King Charles the First's cousin, Prince Rupert of the Rhine. "A Renaissance man, Rupert was a professional soldier; an artist, a part-time scientist and inventor, and a canny businessman with a growing portfolio. He liked what he heard." ${ }^{5}$

Timing of the pair's proposal wasboth promising aswellspeculative. Not only had the bubonic plague broken out in England, but London 
was in the midst of recovering from its Great Fire of 1666. Alternatively the fur business was prosperous, and having extinguished their own supply in Europe, both the French and English were seeking new sources for its increasing fur demands. "Moreover Hudson Bay, discovered more than a half a century before but still little explored, led straight to the supply." 5

Between 1665 and 1669, the pair of fur explorers would undertake several successful trips on board the Nonsuch ship, yielding an ample amount of beaver pelts; and with the support of Prince Rupert, King Charles II would grant the company its charter.

"And so it was that on May 2, 1670, King Charles II granted a Royal Charter and trading Monopoly over the entire Hudson Bay...", with Prince Rupert named its first governor. ${ }^{6}$

\section{$\underline{\text { HBC Trading Posts to Cities }}$}

With a land area covering 1.5 million square miles (approximately 3.885 million square kilometers), the Company's land ownership would amount to more than $40 \%$ of modern Canada. Geographically speaking, The HBC's land mass would stretch from Labrador in the east, to the Rockies in the west, and from the Arctic in the north, to modern-day
Minnesota and North Dakota in the south. Their Charter gave more than a trading monopoly, but also rights and obligations over their new territories to explore other resources such as minerals, but more importantly, the search for the still folklore and unfound Northwest Passage. ${ }^{6}$

Continuing on from 1673 to 1684 , The HBC would establish its first, in a continued series, of trading posts along both James and Hudson's Bay; Moose Factory 1673, Fort Albany in 1674, Fort Severn in 1680, and in 1684 the still existing and most notably York Factory. ${ }^{4}$

These posts and forts would become the primary points of 
where both Native Aboriginals and Europeans would converge, trading mostly animal furs for European manufactured goods, including firearms, kettles, needles, knives, and so forth. ${ }^{7}$

"Despite how routine that business became, the impact of the fur trade was enormous. It brought together two distinct cultures in a relationship based on mutual benefit." 8 Not only was their an exchange of good between both cultures, but technologies as well; canoes, snowshoes, moccasins, and toboggans to name a few. Eventually, the two cultures would merge resulting in the creation of the
"Métis" people, sometimes known as "the children of the fur trade." 9 The Métis community would eventually be recognized as part a higher social status, exemplified by both British Columbia's first Governor and his wife Sir James and Lady Amelia Douglas. ${ }^{9}$

Threatened by competition during the late eighteenth-century, the HBC would expand its operations into the interior, and continue to set up a string of trading posts and forts along various river networks (which would later lead to the development of several Canadian cities, including Winnipeg, Calgary, and Edmonton). ${ }^{10}$

\section{Battle of Seven Oaks}

By June of $1816^{11}$, the battle of Seven Oaks became a pivotal point for The HBC. Situated just north of Fort Douglas (in what is now the North-End borough of the city of Winnipeg), the battle of Seven Oaks was deemed one of the most violent and bloodiest confrontations between the Hudson's Bay Company and the Northwest Company - HBC's largest fur trade rival, which was largely fought by the Northwest Co. Métis people.

Described by Peter C. Newman in his book Empire of the Bay, the battle between the opposing ideologies was nothing less than a 
massacre:

"At Seven Oaks the bodies of the dead were stripped and dismembered in an orgy of mutilation... Seven Oaks changed everything. No longer a commercial contest with the occasional skirmish and postburning, the struggle between the Nor'Westers and Bay men had turned into a guerrilla war, fought along a four-thousand mile front. For the first time in the long rivalry between the two companies, the fur trade itself had become subordinate to their struggle for supremacy." 11

Between 1816 and 1820, a series of both on field and in-court litigation battlesmaterialized between
The HBC and the Nor'Westers. Consequently in the fall of $1820^{12}$, The HBC would merge with its successful competitor the Northwest Company, allowing the $\mathrm{HBC}$ to span all the way to the Northwest regions of the continent (Oregon/Washington state, and British Columbia). ${ }^{13}$ And

fig. 08. The HBC's SS "Dernes" Ship. Section Drawing. Onion-skin paper. Photograph. HBC Archives Collection. HBCA s4/iii - G1/397

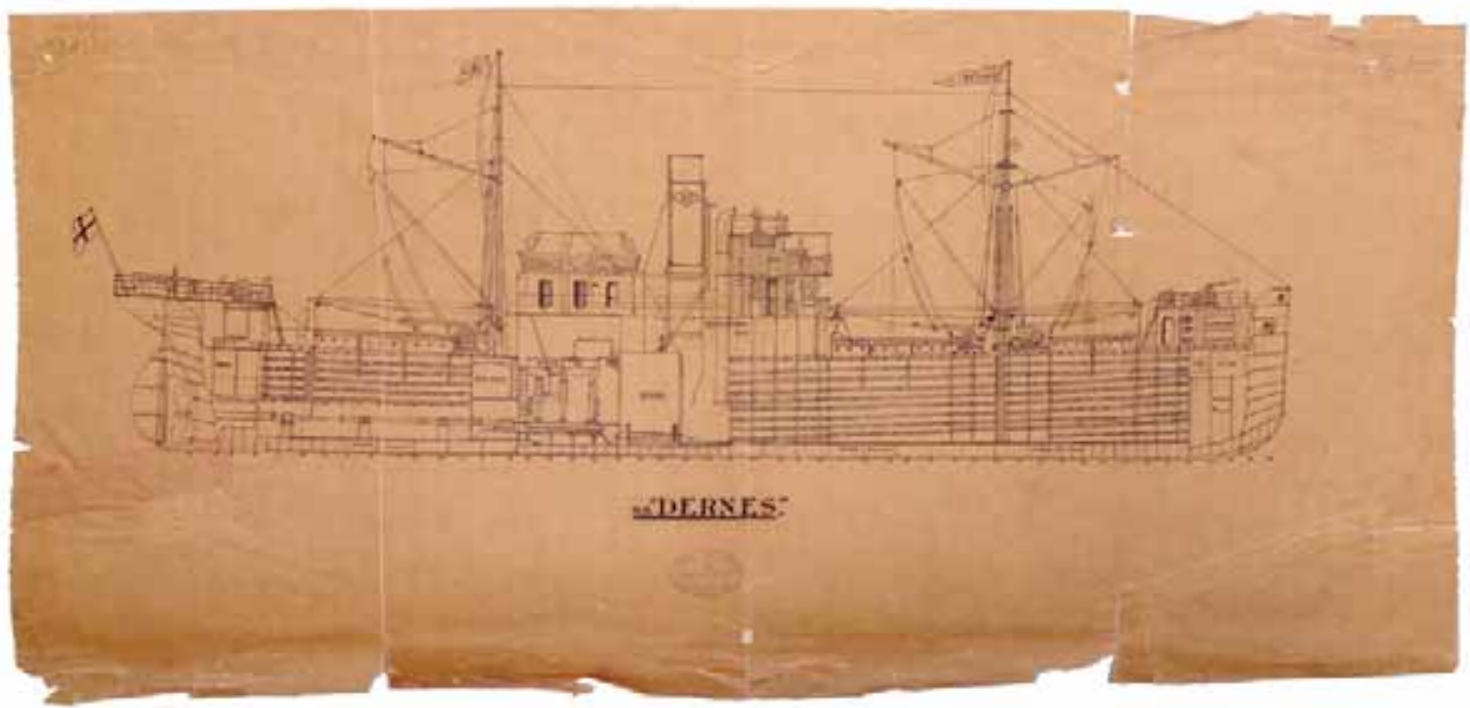

because the company was so deeply invested into the commercial fur business up until then, sourcing these furs also meant determining their whereabouts, which meant the HBC was also deeply committed to the exploration of the New World. ${ }^{14}$ 
From 1563 to 1982 , more than 12,000 maps, charts, plans and architectural drawings were produced by, and for The HBC. Included in these maps and drawings are the HBC's disposal and surrender of land titles, transportation routes, agricultural, urban, and Indian reserves. Architectural drawings include trading posts and forts, department stores; ships' plans, and even includes a golf course in Edmonton. ${ }^{15}$ At one point, The HBC was deemed the largest landowner in the world, owning approximately $15 \%$ of North America. ${ }^{16}$

fig. 09. How to Make a Beaver Hat. Ronald Searle. Drawing. The Great Fur Opera: Animals of the Hudson's Bay Company 1670 - 1970. Toronto, ON: McClelland and Stewart Limited. 1970.

\section{Transition to Retail}

By 1859, the fur trade would begin to lose its importance in the fashion world and The HBC would respond by shifting its efforts and resources to its general stores, which were becoming much more profitable. The following fifty some years, The HBC would increase its retail store presence across the country, allowing

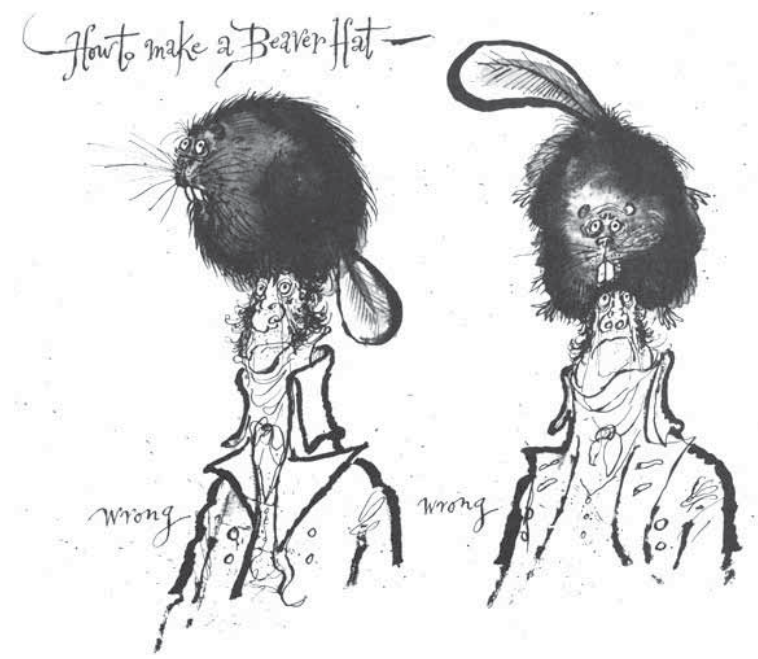

it to later become one of Canada's leading department and retail stores. Following the advice of one of its directors - whom was previously with Harrods department store in London, England - in 1912 The HBC would set about building their "Original Six" department stores in Victoria, Vancouver, Edmonton, Calgary, Saskatoon, and Winnipeg. ${ }^{17} \infty$

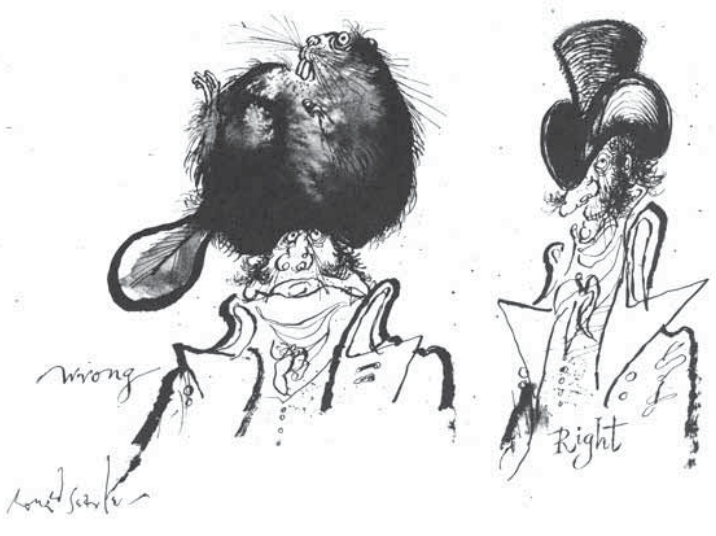


Endnote.

01. Manitoba Provincial Archives. HBCA Holdings. Accessed Jan. 11, 2015 www.gov.mb.ca/chc/archives/hbca/about/hbca_holdings.html

02. Carter, Graydon. Hudson's Bay Company. New York. NY: Assoulin Publishing. 2011. p. 7

03. The Hudson's Bay Company Heritage. Website. Accessed Jan. 07, 2015. www.hbcheritage.ca/hbcheritage/history/people/explorers/ radisson.asp

04. The Hudson's Bay Company Heritage. Website. Accessed Jan. 07, 2015. http://www.hbcheritage.ca/content/timeline

05. Carter, Graydon Hudson's Bay Conpany. New Yok NY: Assouline Publishing. 2011. p. 9

06. Ibid. p. 11

07. The Hudson's Bay Company Heritage. Website. Accessed Jan. 07 2015. www.hbcheritage.ca/hbcheritage/history/overview

08. Carter, Graydon. Hudson's Bay Company. New York. NY: Assouline Publishing. 2011. p. 12

09. Ibid. p.13

10. The Hudson's Bay Company Heritage. Website. Accessed Jan. 07 2015. www.hbcheritage.ca/hbcheritage/history/overview

11. Newman, Peter C. Empire of the Bay: An Illustrated History of the Hudson's Bay Company. Toronto, ON: Madison Press Books. 1989. p. 124 12. lbid. p. 136.

13. The Hudson's Bay Company Heritage. Website. Accessed Jan. 07, 2015. www.hbcheritage.ca/hbcheritage/history/overview

14. Historical Atlas. Website. Accessed Jan. 07, 2015. www.historicalatlas, ca/website/hacolp/national_perspectives/exploration/UNIT_07/U07 overview.htm

15. Manitoba Provincial Archives. HBCA Holdings. Website. Accessed Jan. 07, 2015. www.gov.mb.ca/chc/archives/hbca/holdings/special_media. html\#cartographic

16. http://en.wikipedia.org/wiki/Hudson\%27s_Bay_Company

17. The Hudson's Bay Company Heritage. Website. Accessed Jan. 07, 2015. www.hbcheritage.ca/hbcheritage/history/overview

18. Auld Abigail. WPGxHBC. Website. Accessed Jan. 07, 2015. www. wpgxhbc.com/filter/commercial/commercial-description 



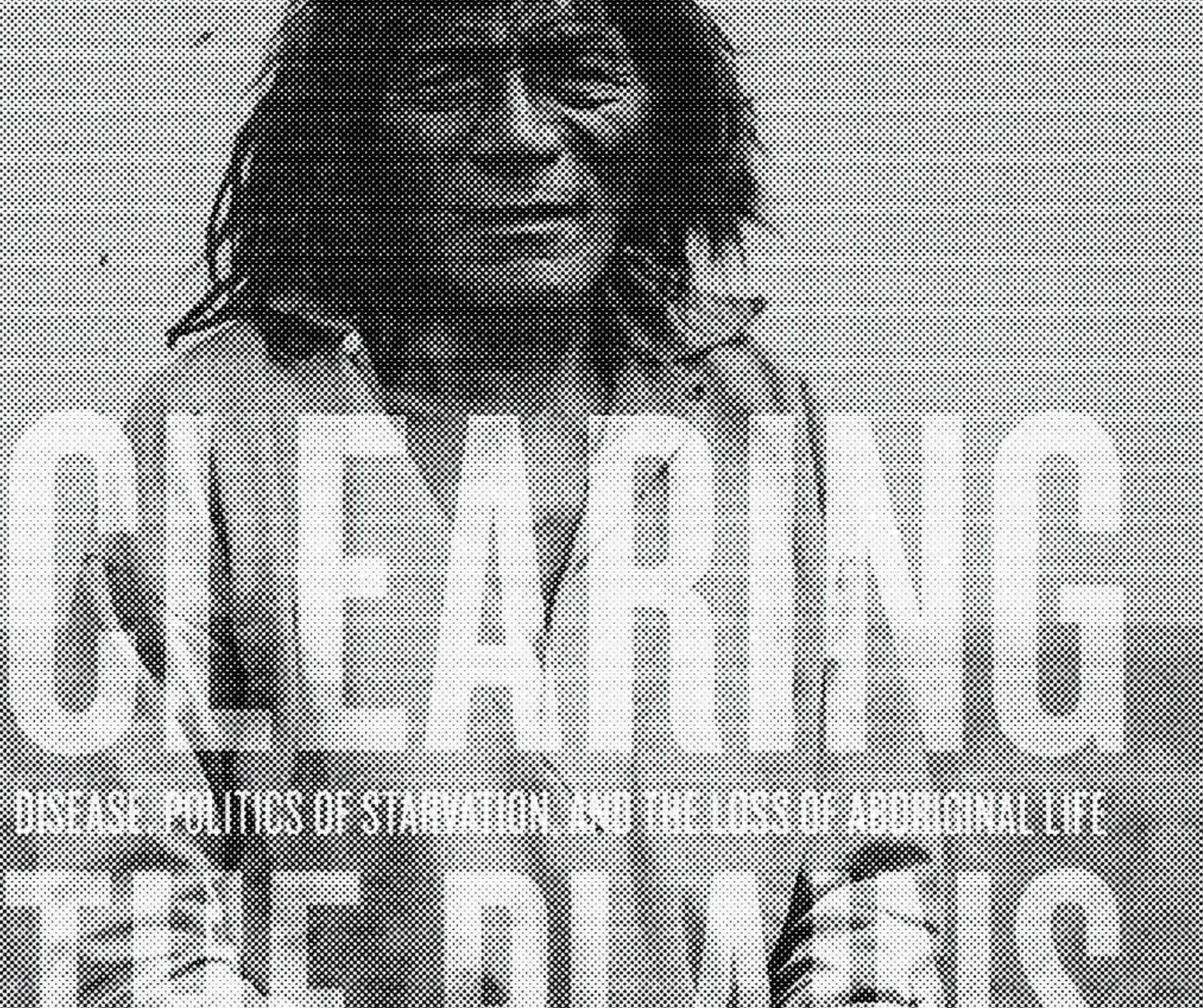


CHAPTER 2

Silenced History:

An Aboriginal Narrative

fig. 10. (previous page) Clearing the Plains: Disease Politics of Starvation, and the Loss of Aboriginal Life, by James Daschuk Book cover. Photo. Personal Collection. 2014.
"At the core of these difficulties is our incapacity to accept who we are. There may be many explanations for this. But the first is that we have shrink-wrapped ourselves into a very particular description of our civilization and how it came to be. We have wrapped ourselves so tight within that description that it has become a straightjacket that expresses the history of another people, a history that would have produced a very different civilization that the one we have."The Power of Story. John R. Saul. A Fair Country: Telling Truths About Canada.

The following books and Politics of Starvation, and the Loss of publications will provide the Aboriginal Life, by James Daschuk; framework for the following and The Other Side of the Ledger: discussions, and whenever possible, An Indian View of the Hudson's Bay primary sources are solicited: Company by the National Film Board A Fair Country: Telling Truths About Canada, by John R. Saul; Bounty and Benevolence: A History of Saskatchewan Treaties, by Arthur J. Ray; Clearing the Plains: Disease,

\section{(NFB) of Canada.}

As noted earlier in the open introductory remarks we pose the following question: what allows the Hudson's Bay Company to be a 
credible icon today, as well as hold to its historical lineage to Canada? From initial explorations, it was easily concluded that it is The Hudson's Bay Company's $(\mathrm{HBC})$ rich narrative, and its abundant contribution to the nation's exploration and development has not changed. What has changed however was the comment put before me by Professor H. Masad Taj of Carleton University Architecture department, "there are two sides to every story." Strongly agreed.

Generally, the HBC's history has been narrated from none other but their own perspective, often briefly acknowledging, or then reluctant to recognize, the important and vital roles of their trading partners: the Aboriginal people. Inundated with important and influential British and French monarchies, explorers, and settlers, the HBC narrative gives little to no credit to the Aboriginal people who were well receptive of these newcomers. The HBC's narrative often negated Aboriginal peoples' contributions to their success, and furthermore, the relationships between both parties today - which is now recognized between Aboriginals and The Crown, or the more commonly known as the Canadian Government.

The Aboriginal people do have a narrative of their own. This narrative

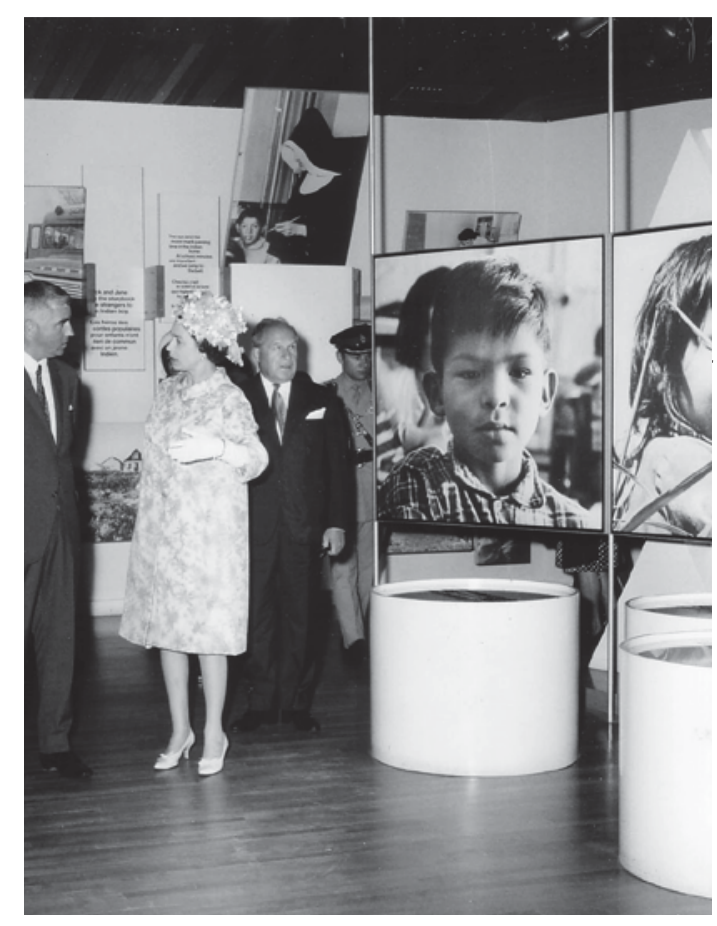

fig. 11. Queen Elizabeth || visiting the Indians of Canada Pavillion. Expo 67. Montreal, QC. 1967. Retrieved from http://4.bp.blogspot.com/-5VIGxiP3tA8/ UTaGngrgyBI/AAAAAAAAKI8/_IoLKLOZ8xs/s1600/ The+Queen+at+Expo.bmp

is rarely given an opportunity to be voiced, yet alone be heard without discrimination. Their narrative is not one that is commonly considered by 
of their silenced history and use an architectural proposal to respond. Though there is a tendency to gloss-over or make sweeping generalizations about events that have taken place, these are but a byproduct from condensing centuries of history and data into a portionsized reading that can be easily digested by the reader in one sitting. By understanding the overlooked and silenced narrative of The HBC, we can gain new insights into how the Aboriginal community suffered anguish and despair.

As with The HBC and their role and contributions to Canada, understanding the Aboriginal

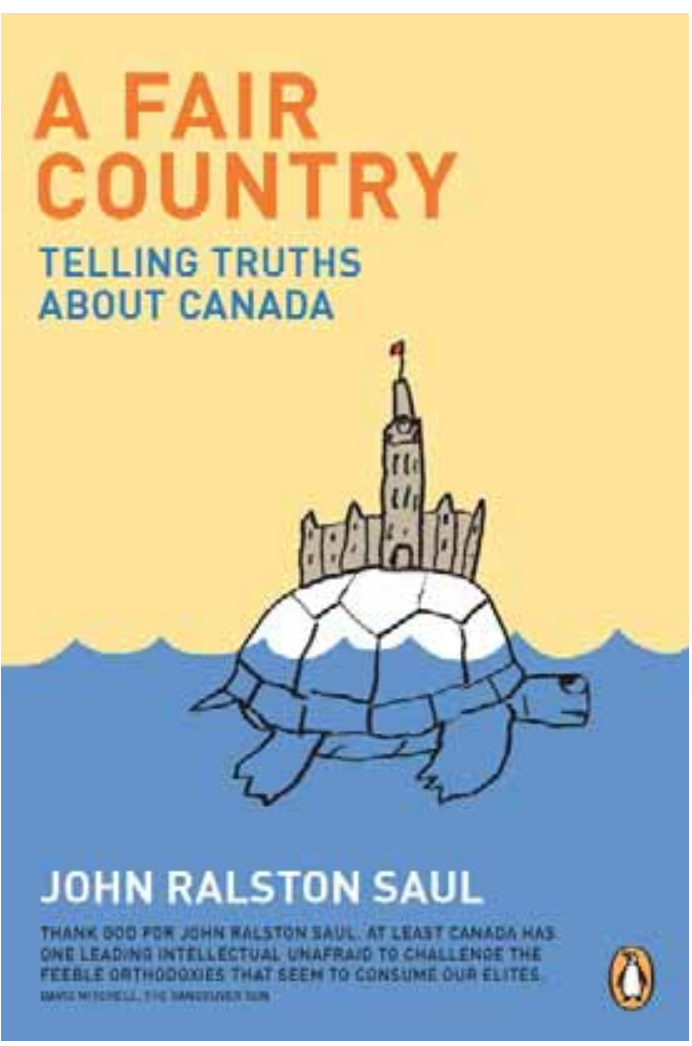

peoples' roles and impacts begins nothing short of a crash course spanning seven to five centuries ago. A critical and well-informed investigation of such issues and
Stranger still, in this process of examining our Western inheritance, and vaunting it, there is scarcely a nod, let alone a meaningful nod, in the direction of the First Nations, the Métis, the Inuit. There is not intellectual, ethical or emotional engagement with what their place might be at the core of our civilization." - John R. Saul.

fig. 12. A Fair Country: Telling Truths About Canada, by John R. Saul. Book cover. Photo. Personal Collection. 2014.

related topics including disease and its role, The $\mathrm{HBC}$ as both partner and then employer, Aboriginal's views and values, as well as Canadians' selfidentity today - none of which were 
readily revealed when examining The $\mathrm{HBC}$ narrative without some scrutiny.

Before commencing, let us assert: there is a strong link and association between language, history, and identity. All elements cannot stand alone; they are concurrently dependent upon one another. Language can inform how a society maintains its history, which results in how one identifies onself as an individual and part of a group or community. Identity can therefore be seen as the culmination of - but not limited to - a people's history and their language.

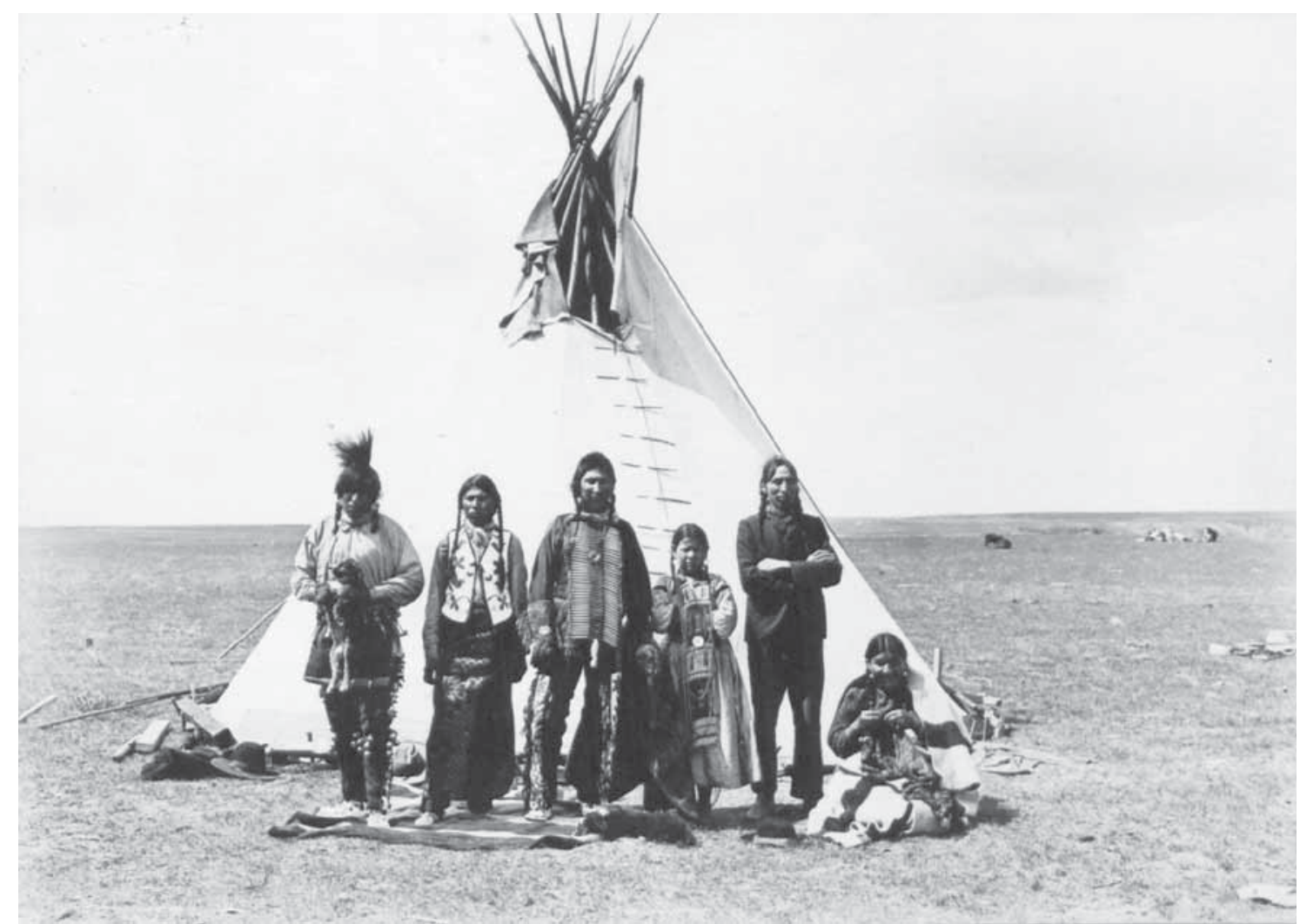

fig. 13. Group of Crees on Plains. Photograph. Unknown. 1916. Retrieved from http://en.wikipedia.org/wiki/Bureau_of_ American_Ethnology

Disease and its role

"The singularity of the encounter between the ecosystems of the Old World and the New in the past 500 years is hard to fathom. Never has there been a comparable 
environmental and human transition. The equivalent exchange of goods, flora, fauna, people, and microbes could only be repeated if there was an exchange of life forms between planets."6

Dating back nearly sixmillennia ${ }^{3}$, the Aboriginal people's presence has been traced on both Canadian and American soil. Long before contact with Europeans, Aboriginal populations were deemed to be as high as +90 million ${ }^{4}$. And inconclusively - with the advent of European and the disease(s) brought with them, Aboriginal numbers have said to have been reduced up to 95 percent $^{4}$ - this debate between researchers and academics relentlessly continues. Regardless of which way the numbers are compiled or calculated, the introduction of foreign disease was both certain and unavoidable; North America was in no way immune to any disease.

The arrival of Tuberculosis (TB) - a fatal disease transmitted by air that attacks the lungs - has been traced as far back as 1200 to 1399 $C E$, centuries before the first arrival of Europeans ${ }^{5}$. As indicated by James Daschuk in his book, Clearing the Plains: Disease, Politics of Starvation, and the Loss of Aboriginal Life, TB is hypothesized to be the result of Plains Aboriginal's main food supply: the bison, on which they heavily relied on. "Veterinarian studies from the twentieth century have shown that under conditions of stress bison are extremely susceptible to TB, and the consumption of dried meat from infected animals could easily spread to humans." 7

To add context, like any society or species, an essential part of survival is the accessibility to fresh water - which is also of consequence to why Canadian townships/cities are almost always located or adjacent to a body of water in some manner. The accessibility to adequate drinking water throughout the Prairie Plains for some larger communities was at times 


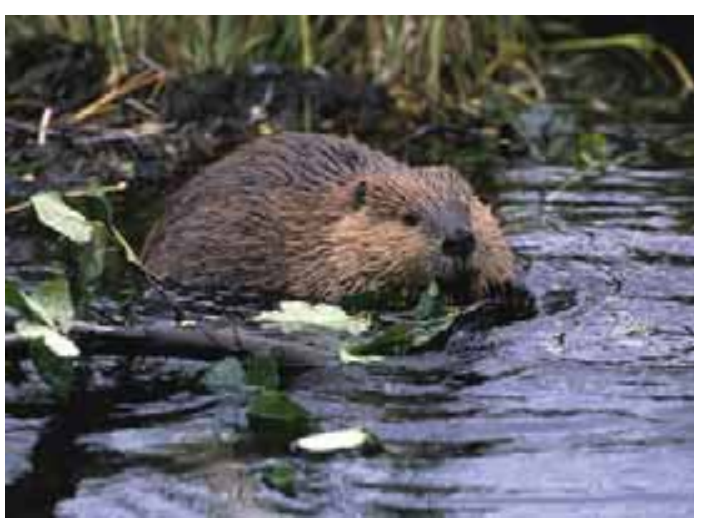

fig. 14. North American Beaver. Photograph. Josh Nagel. Retrieved from http://www.joshnagel.com/?p=936

problematic, and even fatal during times of severe drought. The solution was the community's implementation of a water management strategy, which included the assistance of beavers. The beaver's ability to dam small rivers and streams consequently helped supply the community with a reliable source of water. As a result, the hunting of the beaver for many
The relationship between the species [beaver] and plains people is so deep that religious practices involving beaver medicine bundles continue to hold deep significances among Niitsitapi people evein in the twenty-first century." 9

Aboriginals was avoided whenever possible, and thus the bison became more and more of a staple for the Plains Aboriginal community. ${ }^{8}$

In fact, it was smallpox - a fatal disease affecting the skin, mouth and throat with the presence of a rash and blisters - that was introduced by the first Europeans and made contact with Aboriginal peoples some centuries later (in around the late seventeenth century). The spread of smallpox as an epidemic amongst Aboriginals is but one of several factors resulting in the decline of their population numbers. Though smallpox was introduced to the Aboriginal people via the arrival of European explorers during their explorations, its rate of infection was slow.

Several aspects helped slow its progressive affects, one of which is the length of time it took Europeans to cross the Atlantic Ocean before reaching the shores of the New World. If the host carrier of the disease was aboard the ship headed west to the New World, as author J. Daschuk 
points out that,"... sea voyages lasting six weeks or more, infections aboard ship often ran their natural course and expired before landfall."10

In conjunction to the slow introduction of smallpox from first Europeans, spread of the disease is reported to have also been from more than one direct source. Anthropologist Clark Wissler recounts how the prominent horse trade route between New Mexico and the Rocky Mountain region of (now) Alberta was said to spread the disease at such a rapid and expedited rate, that its arrival was well before that of Europeans in many regions throughout the west. ${ }^{11}$
Later during the fur-trade eras, in order to help mitigate the spread of disease amongst the two societies, contact between those HBC employees residing at trading posts and First Nations women were strictly prohibited. This arrangement helped slow the spread of most diseases until mid-eighteenth century. ${ }^{12}$

From these findings, one can speculate that the spread of disease and its role as a contributor to the near loss of Aboriginal's identity and livelihood - whether it be TB or Smallpox - cannot only be direct attributed to the arrival of first Europeans. Perhaps in an indirect way, but the role of disease

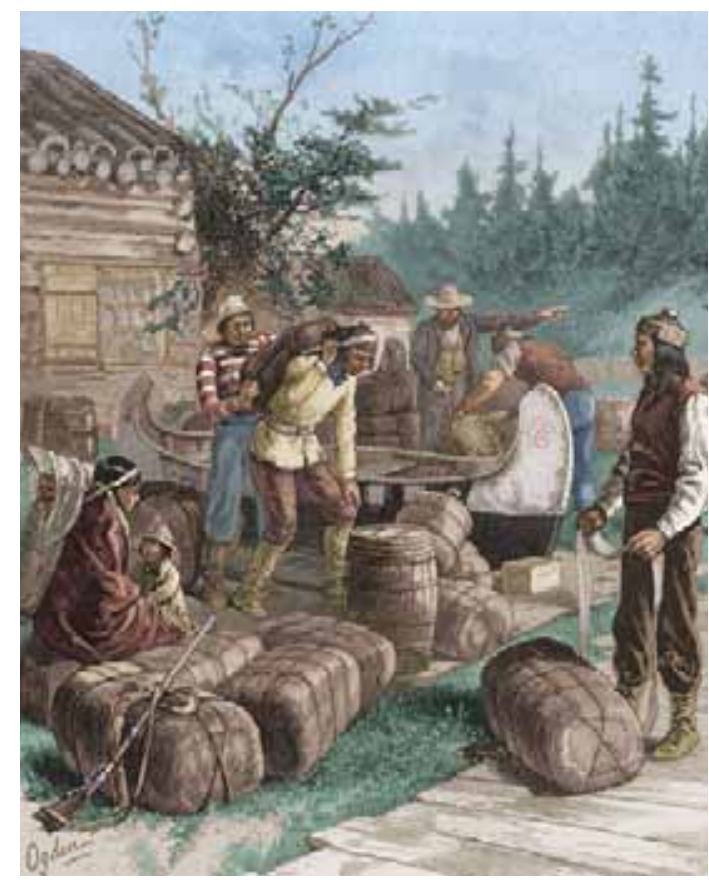

fig. 15. Indians at HBC Trading Post in 1800s. Engraving Unknown. Getty Images. Retrived from http://www. gettyimages.com.au/detail/news-photo/colorizedengraving-shows-activity-at-a-hudsons-bay-companynews-photo/71630687

in this instance tends to be more of a "historical force"13 and a re-shaper of community size and numbers. These diseases do not discriminate 
between race or between the sick and poor - their arrival and impacts were inevitable.

\section{HBC as Partner and Employer}

George Manuel narrates, in the opening sequences of the film The Other Side of the Ledger: An Indian View of the Hudson's Bay Company, "This ludicrous ceremony [the offering of two beavers upon the Queen's arrival in Canada] is not to be taken lightly. It represents an incredible bargain made between Crown and Company. A bargain, which we feel, resulted in the misery, deprivation, and exploitation of Canada's indigenous peoples."13

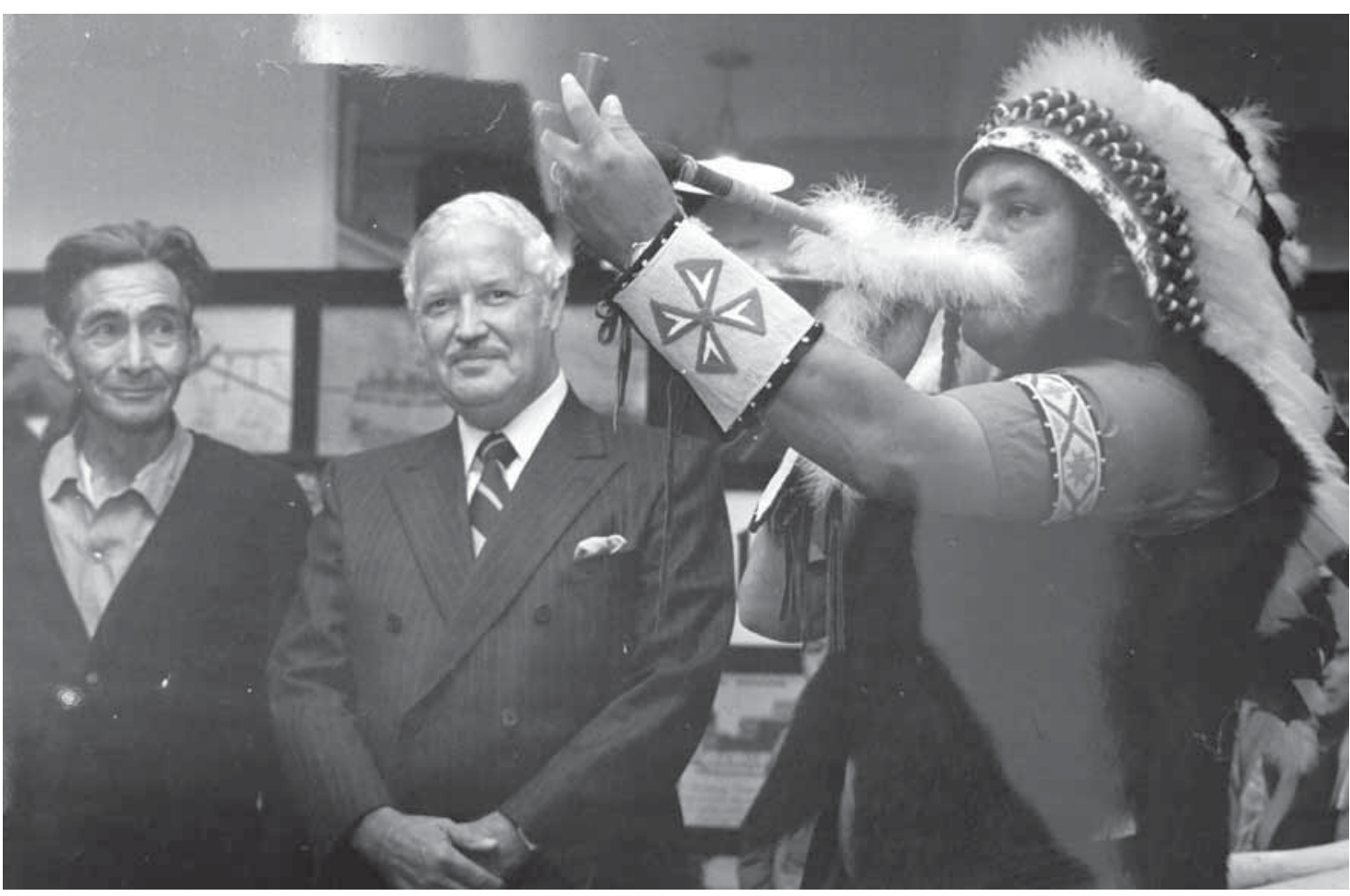

fig. 16. Native People's Trade Fair held at the Bay, Winnipeg. June 25 - July 6 to help commemorate 300th anniversary. Man in centre is C.E. Potter, Sales Promotion (Advertising) Manager. Photograph. HBC Archives. HBCA 1987/363-W$316 / 377$

Whenever there is the confrontation between any distinct culture for the first time, relationships - good or bad - will inevitably result. Between the Aboriginal people and the first Europeans, we are often left knowing its consequential resulting effects, and often enough, not actually 
questioning how it all came to be. The roles of tThe HBC as an equal partner with Aboriginals quickly turned to that of an employer-employee nature, with Aboriginals succumbing to the latter. This shift in hierarchy between both parties, which took with it the mutual respect, equality, and tolerances, can be said to have led to the current state of affairs and endeavors of Aboriginals today.

Ideologies and convictions, such as landownership for profit, were not part of Aboriginal's beliefs and values; Aboriginals regarded all land to be equally shared by all. And, because of their dependency on the land and its resources necessary for their continued livelihood and wellbeing, a deep and profound respect for nature and its elements resulted and can be observed within many, if not all, aspects of their culture and spiritual beliefs. This quickly changed shortly after The $\mathrm{HBC}$ arrived to conduct their profiting fur-trade business. The fur trade brought with it an influx of imposed changes for the Aboriginal people, some positive, but for the most part, a constant threat to Aboriginal's way of life.

The introduction of items such as brass kettles, spoons, or wool made articles, greatly benefited Aboriginals, but on the other end of
Big Bear, Poundmaker and Sweetgrass were particularly famous for their complete exposés on the land and relationship of people to it, the necessity for a stable coalition among First Nations, the importance of their own spiritual beliefs and above all the nature of ownership. They kept pointing out the impossibility of anyone owning land in the sense Ottawa asserted. ${ }^{{ }^{2} 6}$ 
the spectrum, items like the rifle, and alcohol would eventually become a major influence on the deterioration of their livelihood, and eventually their identity. "The introduction of this one weapon revolutionized our way of life. Old hunting methods were abandoned as our dependency on the rifle increased." 14A These European goods soon became objects of desire, and The HBC's greed for profit eventually lead to aggressive land and resource conflicts.

As stronger dependencies on European commodities increased, so did the retrieval of furs and their unfair trade. James Daschuk writes, "another cause of territorial

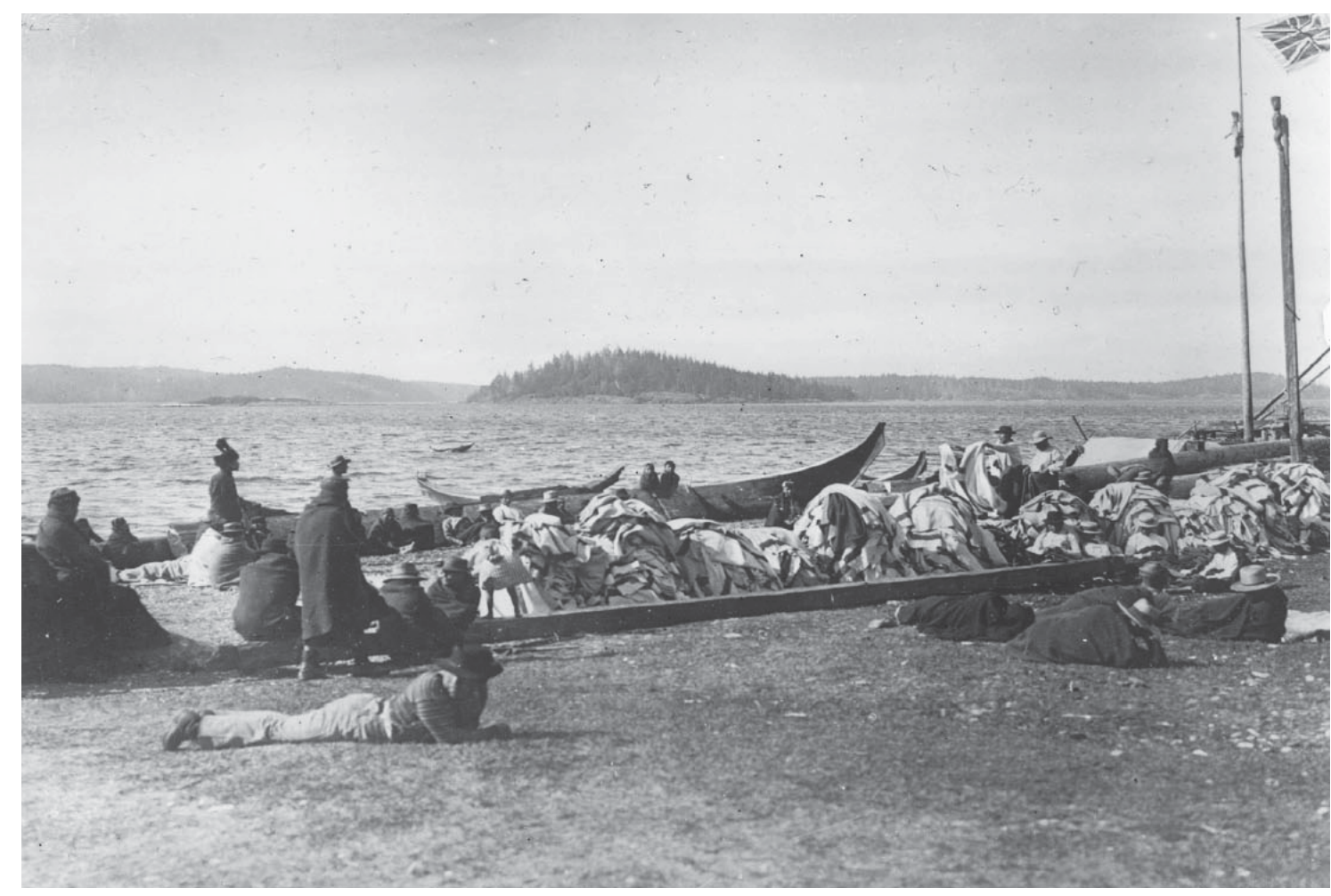

fig. 17. "Potlatch at Fort Rupert. Piles of Hudson's Bay 'Point' Blankets are being counted out for giving away. Haida canoes are drawn up on the beach." 1890. Photograph. H.I. Smight. Images retrived from HBC Archives. HBCA 1987/363-W-114/6.

I can't place anything on any real development that The Hudson's Bay has done in this country. Other than exploit; especially the Indian people."

- Walter Deiter. Ex-president of National Indian Brotherhood ${ }^{14}$ 
dislocation was military conflict between First Nations over control of access to European goods. "15 Driven by the desire for higher profits by tThe HBC investors back in England, markups of three to four hundred percent were all too common, resulting in the eventual scarcity of furs available for trade ${ }^{16}$. Tensions and conflicts between competing furtrade companies increased - primarily between The Hudson's Bay Company and The Northwest Company - with Aboriginals as their employees at its front lines, "... decades of conflict as they [the Cree] encroached on the land of the Chipewyan Dene in search of furs." ${ }^{15}$

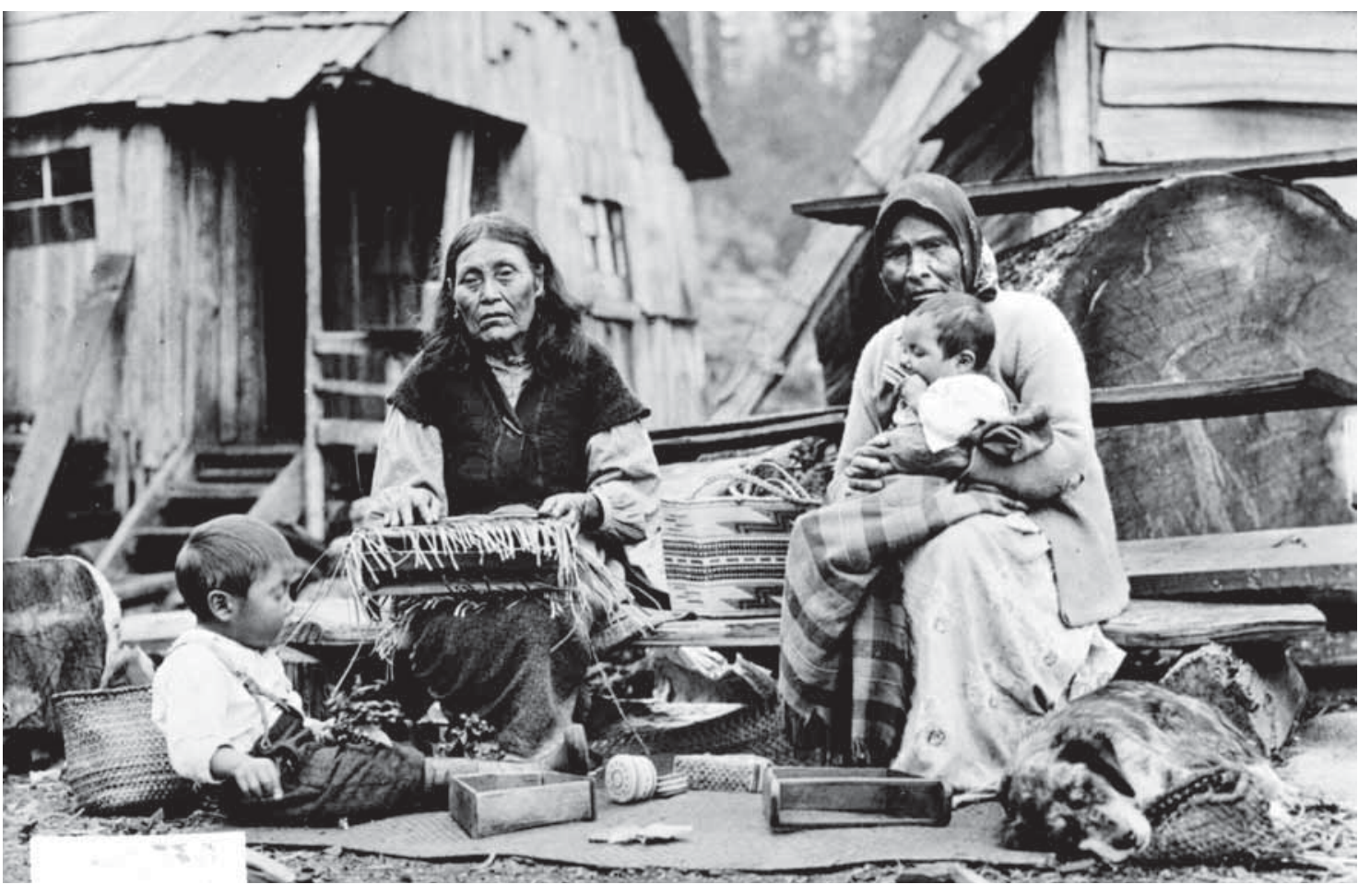

fig. 18. Women and children left behind at HBC camps. Photograph. Unknown. Image retrived from http://www.fnha. ca/wellness/our-history-our-health

The fur trade also brought with it the deterioration of the Aboriginal family unit. An increased demand for a shorter supply of furs meant that fur trappers were continually away from their homes and families for longer periods of time. The search for scarcer furs drove trappers, 
usually the male or strongest woman of families, further away from their homes, and into lands owned by other fur companies/competitors, directly contributing to the violence associated with the desire for higher profits overseas. ${ }^{17}$

All factors up until then were seen as contributing factors to the deterioration of culture, pride, and identity for Aboriginals. It has been said that the 1869 transfer of Rupertsland from The HBC to The Dominion of Canada resulted in centuries of anguish for Aboriginals. The HBC had gone behind the backs of the Aboriginal people, and signed over the land, and with it, the
Aboriginal people and their rights ${ }^{18}$. The Red River Rebellion (described further in Chapter 4), and the Battle of Seven Oaks (described previously in Chapter 1) are but two of many violent consequences resulting in the chain of events that plague Aboriginal people today - racism, inequality, violence, and the loss of their livelihood. Overhunting of the bison by European settlers meant fewer resources available and the chance of survival for the Aboriginals, whom were dependent on them.

Eventually pushed out of desirable lands they occupied, forced into denouncing their identities through the Canadian Government's horrific Residential School Programs, and eventually left to fend for themselves, Aboriginals were left in despair as The HBC relinquished responsibilities and agreements they had with the Aboriginal people, and turned those responsibilities over to the Dominion of Canada. "The declaration [by Louis Riel] stated that the Hudson's Bay Company had abandoned the people to a 'foreign power,' without their consent." as described by Greg Shiliday in his book A History of Manitoba: Volume One - Rupert's Land to Riel ${ }^{19}$. Treaty after treaty was produced and signed, compelling Aboriginals to essentially give up their rights; all to satisfy the 


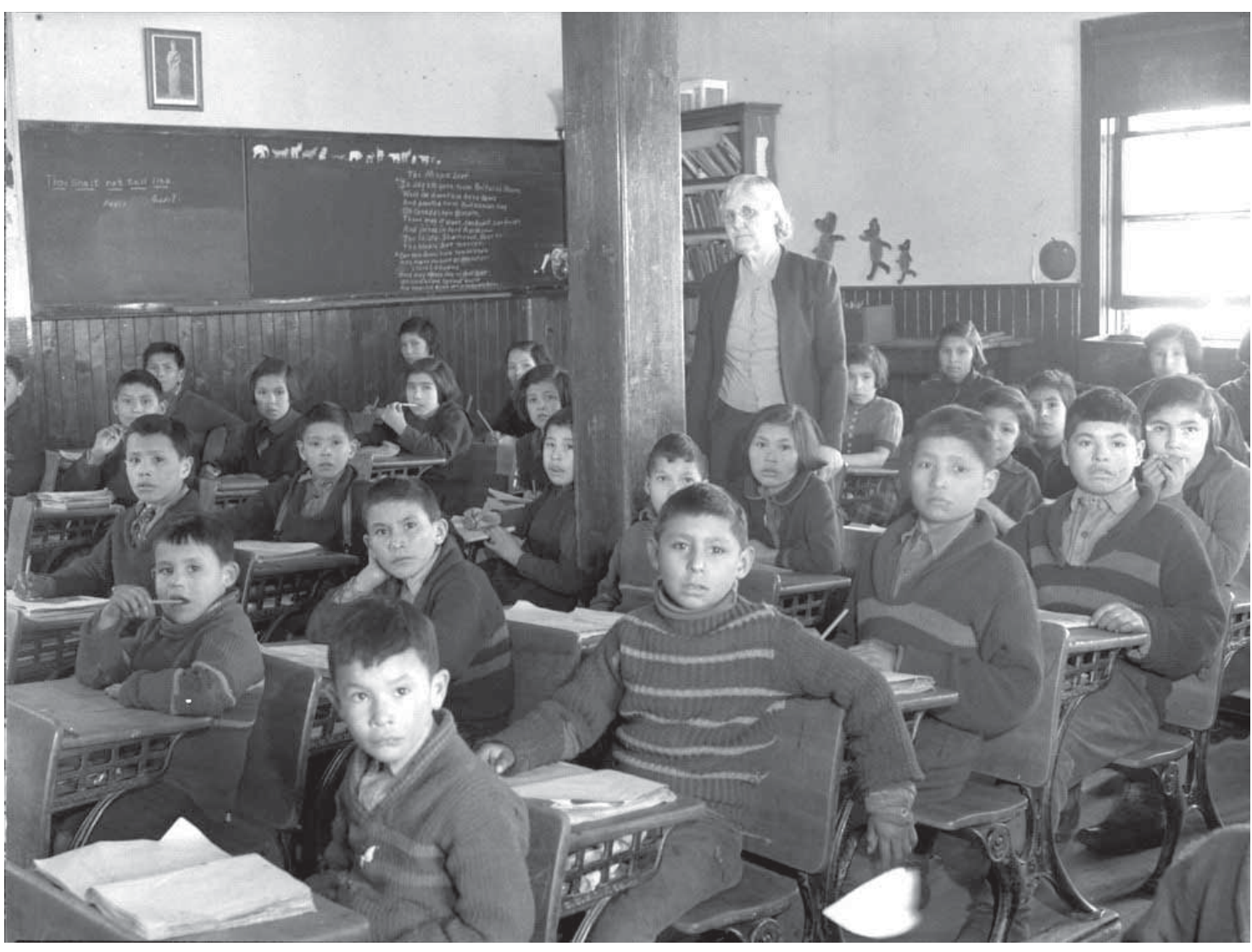

fig. 19. The blackboard on the left reads: "Thou Shalt Not Tell Lies." Cree students at the Anglican-run Lac la Ronge Mission School in Saskatchewan in 1945. Photograph. Archives and Library Canada. Image retrived from http://www.huffingtonpost.ca/charlieangus/residential-school-st-annes_b_4166741.html 'egocentric' needs of The Crown and

their ambition for territorial expansion

(explained in length in Chapter 4).

\section{Aboriginal's Values and Principles}

Today, many Canadians are contemplating what it actually means to be a Canadian. Canada receives an average of 250,000 immigrants annually 20 (since 1991). This influx of immigrants has resulted in Canada becoming a mosaic of foreign cultures and societies, making it increasingly difficult to pinpoint, or describe for many, what it means to be a Canadian. And for many Canadians, Aboriginals are not in the foreground of what is means to be Canadian.

Though for the most part only formally acknowledged, Aboriginals as a founding pillar of Canada is often never openly accepted. Instead, 
many Canadians view Aboriginal people as problematic, hindering the advancements of their urban communities, and as failures, "We see them insisting on old treaties and bad land, which we forget the we made sure they signed and lived on" 21 as John Ralston Saul points out in A Fair Country: Telling Truths About Canada. In actuality, many Canadians' values and beliefs are those of Aboriginal's values and beliefs, and these principles extend even farther back than The HBC, "New France, the Hudson's Bay Company and the Northwest Company consciously built their place here on the indigenous ideas of mutual dependency and partnership."22 Ideas such as nonracial civilization, an all-inclusive civilization are based on the symbolic nature of the circle, which expands and gratefully accepts new people to join. ${ }^{23}$

The racial mixing between First Nations people and the French resulted in the Métis race. The intent for the melding of both races was of course beneficial for both Aboriginal and French parties, perhaps some more than others, as both had different agendas in their pursuit. For the Aboriginals, they saw it as an opportunity for both parties to become equals, extending well beyond the scopes of the fur
The constant point is this. Throughout the country and over the centuries, marriages were carefully negoticated between daughters of chiefs or of other leaders and strategic players among the newcomers. On one side - the First Nations - this was a traditional way to build alliances. On the other - the newcomers - it was a policy aimed at improving their lives and at stabilizing and controlling the fur trade."- John Raulston Saul. A Fair Country: Telling Truths About Canada. ${ }^{25}$ 
trades; a long term relationship. For the French, it became more of a political, and financial strategy, "His masters [Champlain's] in Paris sent him constant instructions to subject the locals to French control, to assert European racial, cultural and political superiority. He was on the spot. He knew better. He knew what reality required. The he made such a declaration suggest that he felt his colony's position to be weak. But it also suggests that he believed such a mix of the two civilizations could work." 24

Later, the HBC would see the benefits of such race interactions between their French competitors and First Nations, and would implement similar schemes for their further advancement, John R. Saul writes:

"The British, during their ongoing campaign to gain control of Nova Scotia, noted this and at one point tried to catch up by offering a stipend to any soldier who married an Aboriginal. The Hudson's Bay Company built its network - for more than two hundred years on one of the world's largest commercial and political structures - in good part through interracial marriages. "25

These differences in agenda were not surprisingly extended to visions on how the land and its resources were to be developed by either Aboriginals or their European colonizers. Aboriginals viewed the land for its long-term livelihood advantages, yet the Europeans would see them as their inheritance ${ }^{27}$ once Aboriginals and their way of life have been eventually eradicated.

\section{$\underline{\text { Resistance is Futile }}$}

As Renée Dupuis, chief commissioner of the Indian Claims Commission points out " the history of North America has not yet been written. It is still written in English from anglo-francophone point of view, etc. One of the reasons we are blocked is that we seem unable to look at our 
roots in a collective manner. We are stuck on the colonizing roots." 29

So why is it then, that many Canadians today still have a difficult time in seeing our relationship and association with Aboriginals and their values? For the most part, Canadians have difficulty describing what it actually means to be Canadian, never mind including Aboriginals as one of its main pillars. The negative view of Aboriginals and that they are but a victim are all too common beliefs that linger today. In actuality, Aboriginals are a resilient group of people that have survived off the land for millennia, long before the arrival of Europeans. Without the survival

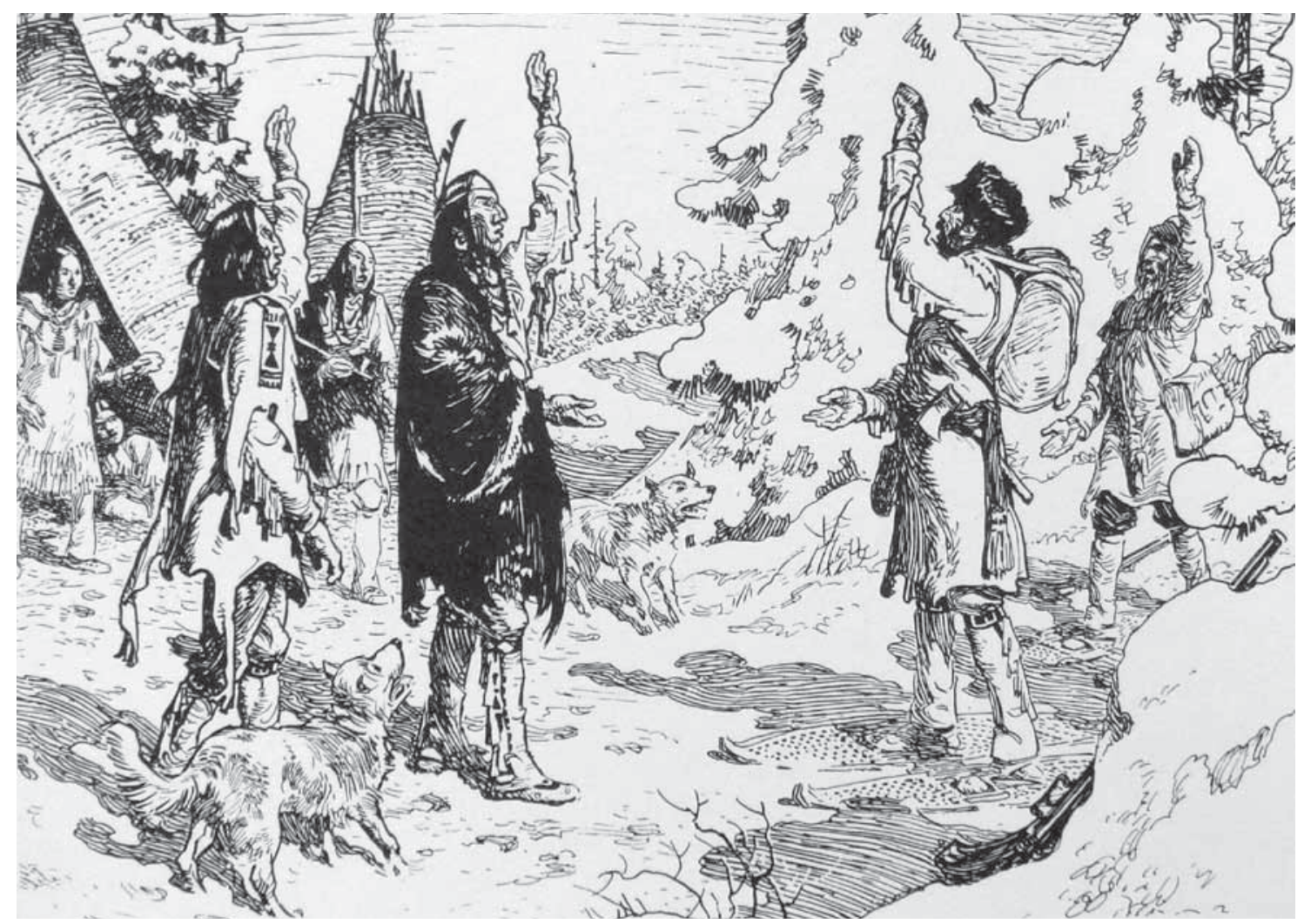

fig. 20. Arrival of P.E. Radisson at an Indian Camp in 1800s. Engraving. Unknown. Getty Images. Retrived from http://en.wikipedia.org/wiki/Coureur_des_bois

Why do we continue to stumble and resist and deny when it comes to this Aboriginal role in Canada? The most obvious answer is that we don't know what to do with the least palatable part of the settled story. We wanted the land. It belonged to someone else. We took it." ${ }^{\circ}$ 
techniques taught and offered to those first European explorers, many would have perished. And today, Aboriginals have raised their voice, and are being heard again, but then again, Aboriginals have always had "agency"32. As Canadians we are too insistent trying to come to grips with our self-identity alone; it must be something we do with Aboriginals, "[o]therwise, it will be just another romantic delusion." 31

In order to develop a better appreciation and comprehension of Aboriginals and their plight, the reader should initiate their own inquiries that hopefully extends and materializes beyond these pages; this thesis serves as both a primer and catalyst for that initiative. $\infty$ 


\section{Endnote.}

01. Saul, John Ralston. A Fair Country: Telling Truths About Canada. Toronto, CA: Penguin Canada. 2008. Print. p. 4.

22. Robertson, Jesse. Uncomfortably Canadian. Website. Oct. 15, 2012. Accessed Dec 26, 2014. http://uncomfortablycanadian.wordpress. com/2012/10/15/john-ralston-sauls-metis-country/

03. The Forks. Website. The Forks 6,000 Years Ago. Accessed Dec. 18 2014. http://www.theforks.com/about/history

04. Daschuk, James. Clearing the Plains: Disease, Politics of Starvation and the Loss of Aboriginal Life. Regina, SK: University of Regina Press. 2013. Print. p.1

05. Ibid. p. 8.

06. Ibid. p. XI.

07. Ibid. p. 10.

08-09. Ibid p. 7

08-09. Ibid. p. 7

10. Ibid. p. 12

11. Ibid. p. 23

12. Ibid 14.

13. The National Film Board of Canada. The Other Side of the Ledger: An Indian View of the Hudson's Bay Company. Film. 42 mins 22 secs. 1972 $02: 55$ mins. Accessed Oct 13, 2014. https://www.nfb.ca/film/other_side of_the_ledger

14A. Ibid. 06:26 mins.

14B. Ibid. 04:50 mins.

15. Daschuk, James. Clearing the Plains: Disease, Politics of Starvation, and the Loss of Aboriginal Life. Regina, SK: University of Regina Press. 2013. Print. p.17.

16. Ibid. p. 29.

17. Ibid. p.16

18. The National Film Board of Canada. The Other Side of the Ledger An Indian View of the Hudson's Bay Company. Film. 42mins 22secs. 1972. 02:55 mins. Accessed Oct 13, 2014. https://www.nfb.ca/film/other_side of_the_ledger

19. Shilliday, Gregg. A History of Manitoba: Volume One - Rupert's Land to Riel. Winnipeg, MB: Great Plains Publications, Ltd. 1993. p. 174.

20. Immigration Watch Canada. Website. Canada - Immigration Intake, 1860 to 2013. Accessed March 26, 2015. http://www.immigrationwatchcanada.

21. Saul, John Ralston. A Fair Country: Telling Truths About Canada. Toronto, CA: Penguin Canada. 2008. Print. p. 5

22, Ibid. p. 7

23. Ibid p. 4 .

23.

25. Ibid. 11

25. Ibid. p. 11 .

26. Ibid. p. $28-9$

27. Ibid. p. 30.

28. Ibid. p. 19.
29. Ibid. p. 21

30. Ibid. p. 27

31. Ibid. p. 35.

32. Wilson, James and Darren Courchene. Interviewed by Jagtar Singh. pt.1 - 4:45 mins. 



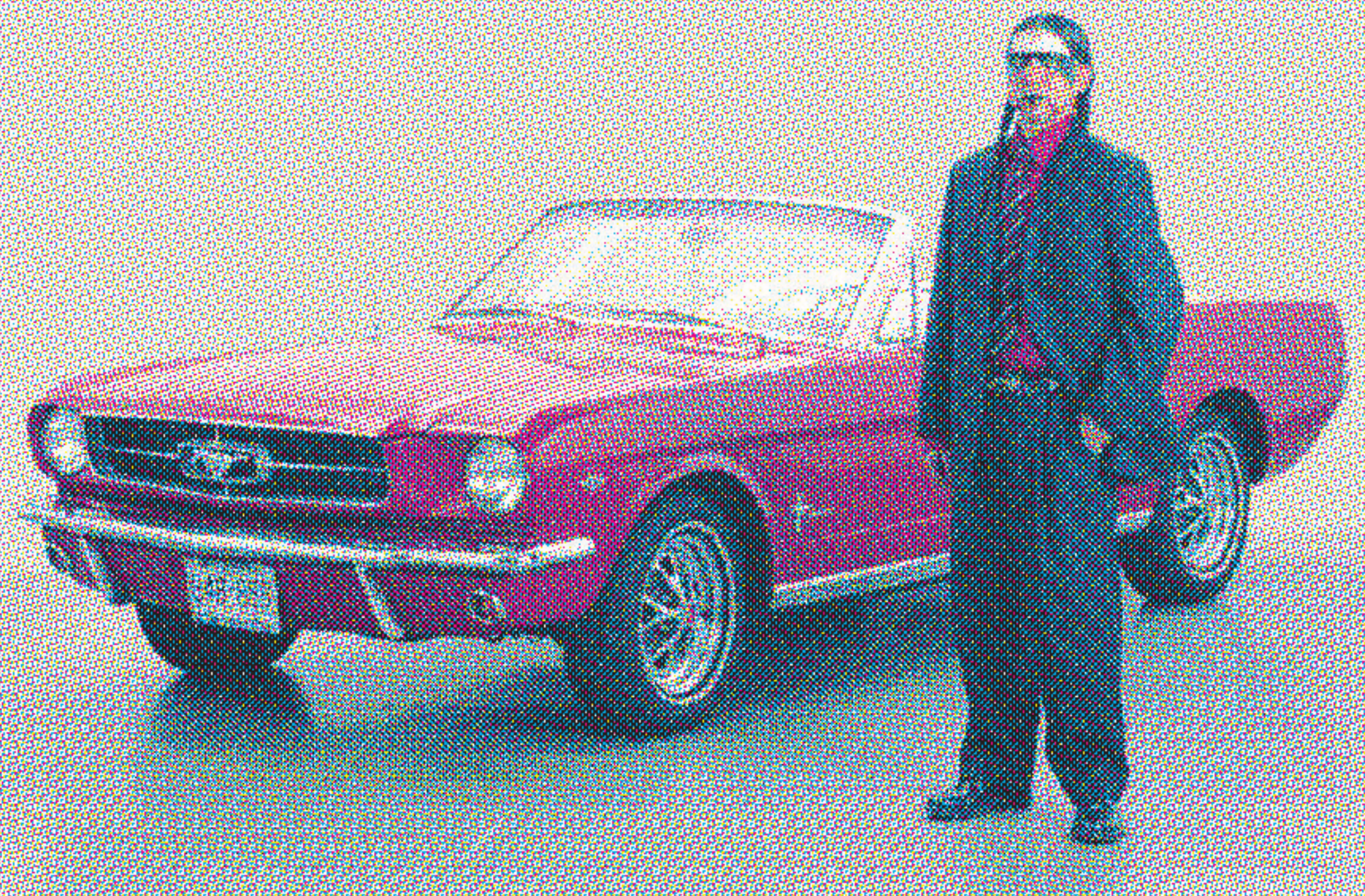


CHAPTER 3

Identity + Loss:

Conversations with the

Commissioner

fig. 21. (previous page) Identity Theft. Dana Claxton Photograph. Image retrieved from http://www.straight. com/arts/dana-claxtons-new-interdisciplinary-workcultural-mashup
My impression is that as people understand our history better, they understand our agency better and our history. We are not just pawns of history any more." - Manitoba Treaty Commissioner James Wilson.

Like many publications "forget the abuses committed by the on topics relating to *Aboriginal Canadian state... It may also make it people's point of view or narrative, too tempting to believe we can know there is the tendency to make aboriginal cultures and conditions sweeping generalizations. Though without actually working to do so"1. these academics, professionals, and Nonetheless, meager as they may writers of such publications are - for be, these act as a critical step in both the greater part - virtuous in their public education, and the Aboriginal intentions, these gloss-overs can narrative being properly heard. result in a self-defeating cause, even before they have had the opportunity to actually materialize themselves into something beyond their hard-covers, allowing many readers to easily
In December of 2014, I had the rare opportunity to meet formally with the Manitoba Treaty Commissioner James Wilson and his assistant Darren Courchene at their office in 
Winnipeg. This meeting afforded me the occasion to have specific questions answered; misconceptions and assumptions clarified; but most importantly, a chance to give these investigations a necessary credibility by allowing the Aboriginal narrative an opportunity to be heard, voiced by none other than those individuals actively involved in such affairs within their community. This provided me the chance to materialize research conducted beyond the context of a library; something of real substance.

Commissioner James Wilson

is of Aboriginal decent and grew up in the Opaskwayak Cree Nation

in Northern Manitoba. Wilson's mother is Scottish, and his father is Cree. Commissioner Wilson grew up on the reserve, but also in the U.S. simultaneously. Wilson's role, within the neutral body of the Treaty Relations Commission of Manitoba office, is as a facilitator or mediator of the Treaty relationships, working with First Nations and the Federal Government, Provincial Government, and businesses to try to rebuild the Treaty relationship. As Commissioner, Jamie Wilson's "greatest aspirations are in education where he fully intends to play a major role in paving a way out and up for aboriginal youth by doing nothing less than helping fix the current corrosion in First Nations

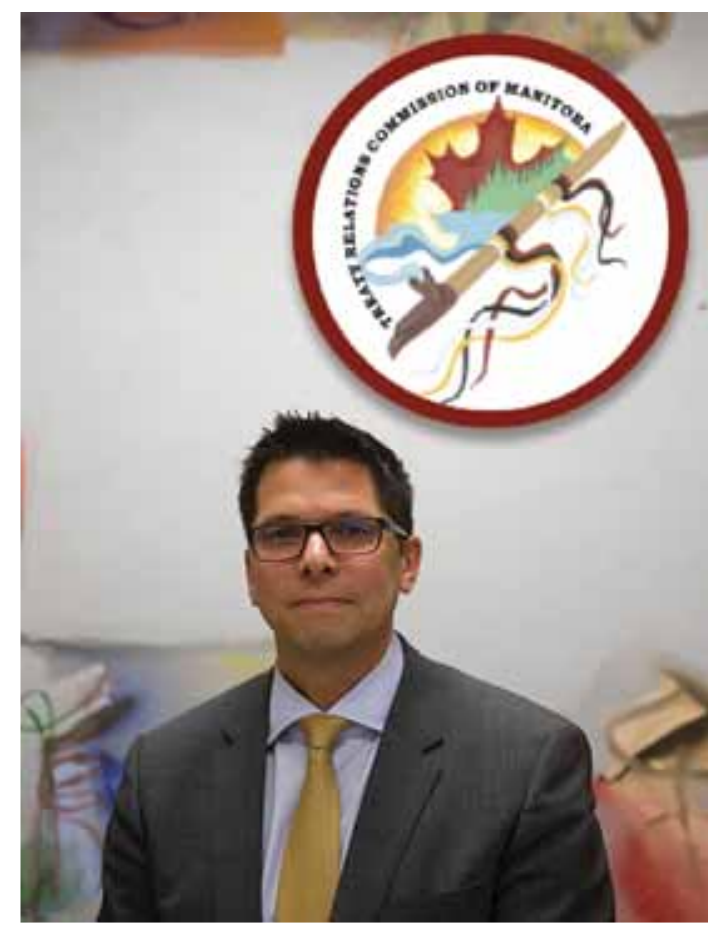

fig. 22. Commissioner Jamie Wilson. Photograph. Maclean's Magazine. Image retrieved http://www. macleans.ca/news/canada/welcome-to-winnipegwhere-canadas-racism-problem-is-at-its-worst/

\section{Education."2}

Darren Courchene's role at the Treaty Relations Commission's organization, an assistant to the 
Commissioner, is primarily that of a researcher. He also possesses a strong background in both the written record and in the oral history of the treaties.

From the conversations between Commissioner Wilson, his assistant Darren Courchene, and myself, some common themes were reiterated throughout: Equality, Education, and Identity.

\section{Equality and Agency}

Highlighted by Commissioner Wilson, Equity, orEqual Representation was one of the three over-arching themes of our conversations. My own confessions of being somewhat biased when it came to Treaties, and who they implicated were brought to the surface, as Commissioner Wilson explained that this was common for many individuals, "I think as people understand the Treaties more, they understand what the relationships should look like, and they understand that there's huge opportunities to work together, and that it was about a partnership."4

\section{Commissioner Wilson also} pointed out how inequalities exist on many levels for the community, ranging from education, employment, and for some it was about "having a voice - they feel voiceless, powerless. But I think it has to do with this equity issue." ${ }^{5}$ For Aboriginals, inequalities in power and their involvement of their level of treatment and rights are another issue of concern today. Often this is caused by the primary source of what an individual learns about another community (i.e. their narrative being unequally represented in the media, and schooling), but also in the level of involvement within their own community in respects to their overall agenda(s), "it's a perspective, having First Nations people having agency. That were not just sitting around hungry, homeless, and then the fur trader shows up, gives us trinkets." 6 These imbalances are the result of how the histories of their 
people are being taught at the public educational level, where Courchene and myself remarked that Canada's significant fur-trade narrative was given unequal teachings compared to other subjects within public schools; the fur-trade was essentially compressed and diluted down to a few classes, accompanied by an inadequately thin booklet.

\section{Education}

Noted earlier, Commissioner Wilson is a strong advocate for the empowerment of the Aboriginal community through education - both formally and informally, when and wherever possible. Wilson extends

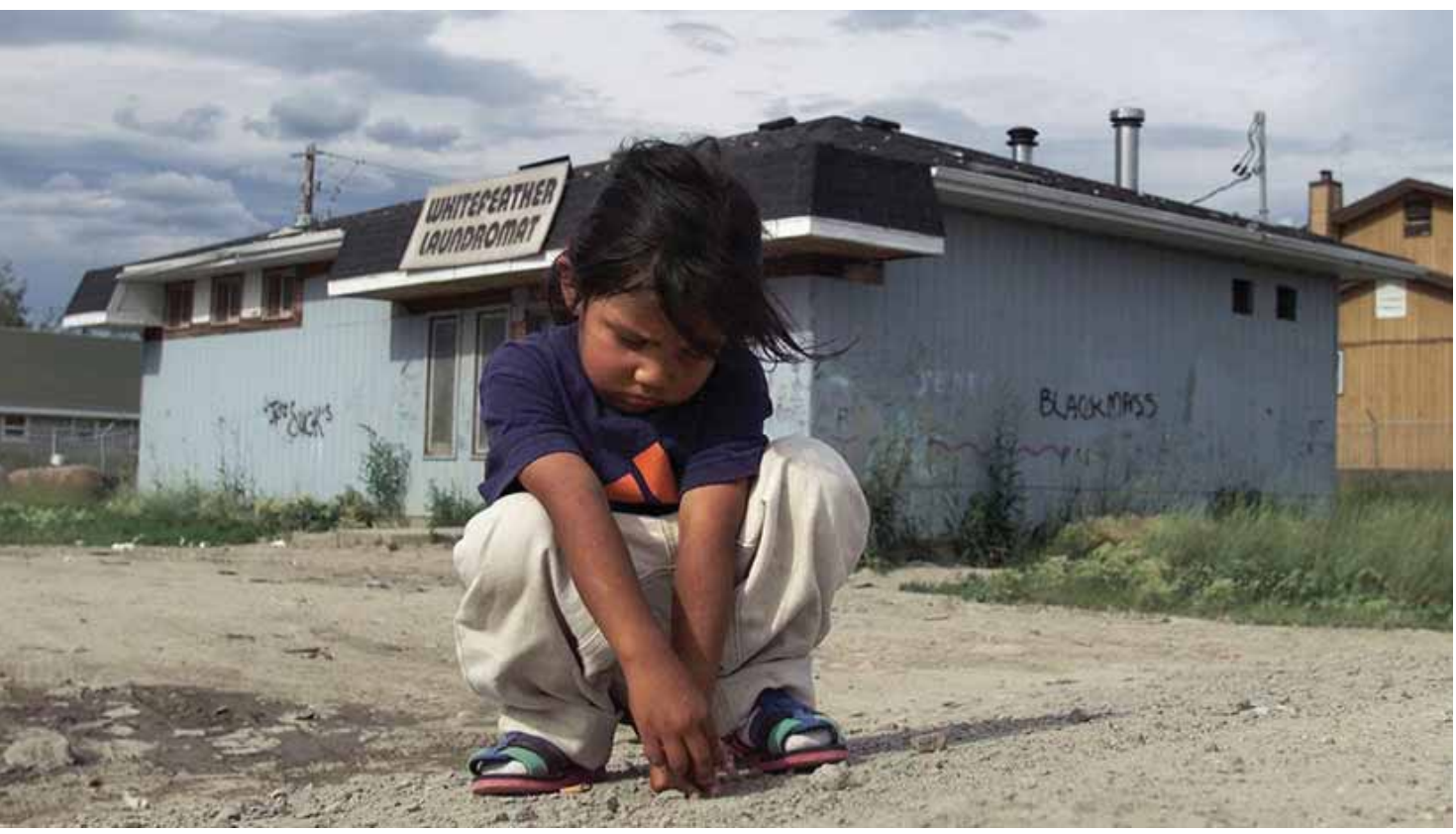

fig. 22. Young girl on a Northern Aboriginal Reserve. Despite popular belief of, many northern communities lack sufficient funds for adequate schools and resources to educate their yourth. Photograph. Bernard Weil. Toronto Star. Image retrieved from http://www.macleans.ca/news/canada/out-of-sight-out-of-mind-2/

this notion of education not only to the Aboriginal community, but the larger public realm. Educating the greater public on Aboriginal history and roles will inevitably create a better understanding of their values and endeavors, and can also foster an acceptance in differences of values and beliefs, Wilson states, "My impression is that as people 
understand our history better, they understand our agency better and our history. We are not just pawns of history any more." 7

Aboriginal education and its roles regarding treaties in the last decade or so has resulted in a shift of beliefs from that of "historically being ripped off in relationships, either through treaties, or through other relationships... [to now a] shifting to an interpretation of the treaties, interpretation of business relationships, like $\mathrm{HBC}$, as one where we're equals at the table. We have the savvy to be there, we had the education to be there. It may not have been western education, but we had strong negotiating skills, we were there as equals." 8

It has become evident, that the Aboriginal level of involvement in affairs regarding their livelihoods are of obvious high importance to them, and they are to be equally consulted and involved in its decision-making. No exceptions. Formal education of Aboriginal treaty rights and responsibilities - through the office's Treaty Education Initiative - has now begun at some grade 5 and 6 elementary level schools within Manitoba, with curriculums currently being created for levels kindergarten to grades 12 . The initiative's longterm goals is to be fully integrated
... there's English and there's French as National languages, how come there is not an Aboriginal one like Cree or Ojibiway?

Commissioner Wilson: Good question." - Conversations with the Commissioner." 14 
into the Manitoba public educational curriculum, and "that every student leaving grade twelve can demonstrate an understanding of treaty and the treaty relationship."9

Informally in the past, education of the subject matter would often take place through personal conversations amongst peers, or it was mainly derived from personal interest as Darren Courchene stated. Courchene also noted, as part of the Treaty Relations Commission of Manitoba office's community outreach plan, the office offers the community a Brown Bag Lunch Series, where they often have individuals come in and talk about treaty issues to its registrants, or else the office often sends out individuals to various events to speak on the office's behalf. Courchene also says, "We have some work to do in house as well"10, where he refers to the community taking on their own initiative, and not being dependent on either government or organization for their knowledge of treaty rights and obligations. Though a difficult step in the process, it is of significant importance to have this willingness to learn.

\section{Voicing an Identity}

For Aboriginal people, as many other cultures and communities, an important part of their Identity is their oral culture and its traditions. Better explained to me by Commissioner Wilson, oral culture is one of the many important facets for Aboriginal people, and it plays a crucial role in sustaining their history, along with their identity.

Throughout colonization, the voices of Aboriginals have slowly been smothered, long considered a huge contributor to their suppression and loss of identity. The Canadian Government's implementation of the *Residential Schooling Programs for Aboriginals not only nearly eradicated their language, but was also seen as a main contributor to the fragmentation of the once close-knit 
Aboriginal family unit, which has had a profound impact often resulting in substance abuse, incarceration, sexual-abuse, and of course further loss of identity.

Commissioner Wilson described an instance when he was younger; his grandfather would recount the story of a man that travelled in a canoe. What stood out from what Commissioner Wilson was explaining was how his grandfather would intentionally leave out pieces of the story. The reason, later revealed to him by his father, was that his grandfather could only retell the story in the same manner in which he heard it told to him basically verbatim. Commissioner
Wilson figured that this story of the man and his canoe was likely centuries old, and that someone along the line forgot, or left out a parts of the story, so now it existed only as that. ${ }^{11}$ This discussion brings forth the notion of authenticity, honesty, and the significance of oral culture in maintaining identity and history as a people of distinct association.

Courchene also pointed out that oral culture comprises a multilayered hierarchy of linguistic skills, and is not as straightforward as many may assume it to be. "There is a higher order of things. There are four layers to our language... Indigenous language, specifically Ojibiway, you

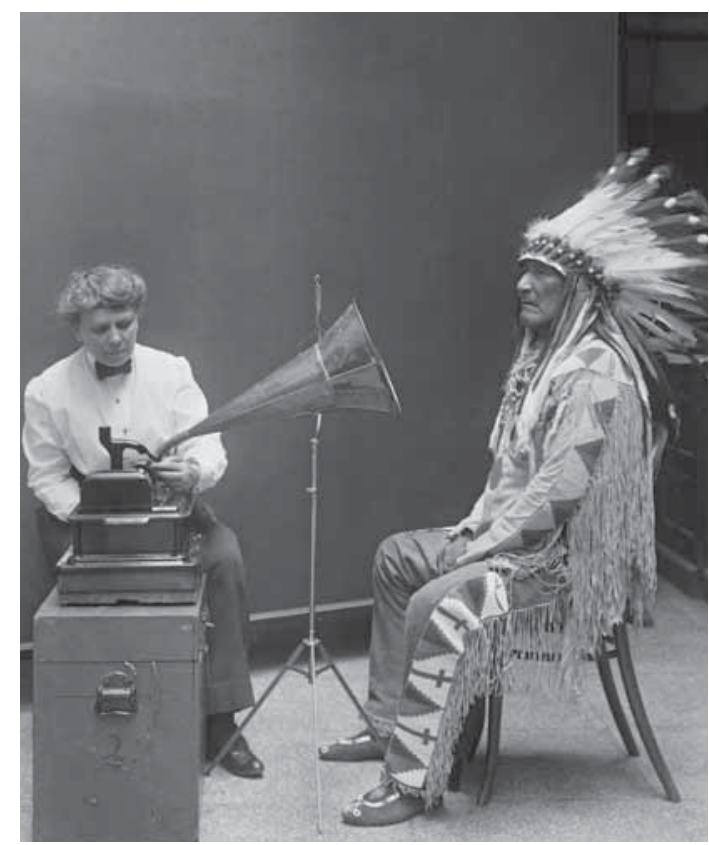

fig. 23. IEthnomusicologist Frances Densmore recording Blackfoot chief Mountain Chief. Photograph. 1916. Image retrieved from http://en.wikipedia.org/wiki/ Bureau_of_American_Ethnology

have everyday common language, you have prayer language, ceremony language, and you have spirit language, and all four of those interact, develop complexity." 12 
The ability for the Aboriginal community to voice their rights, both metaphorically and verbally, has also come to the surface, which is something that has contributed to their suppression. With the strict implementation of the *Residential Schooling Program during the 19th century by The Crown and the devastating affects it has had - both mentally and physically abusing Aboriginals to denounce their culture and identity, and assimilating to the values of their sovereignty - the oral culture was nearly eradicated.

In cities like Winnipeg, Manitoba, which has the largest Aboriginal population per capita in
Canada, only a meager $6.9 \%$ of selfidentified Aboriginal people ${ }^{3}$ are able to speak their native-tongue. In consequence, a significant loss of identity has resulted, along with the loss of the ability to transfer their history from one generation to another. Today, with larger influences of English as primary language within traditional and social media, fewer and fewer youth are able to speak their native language(s). Hence there is an even greater push by the community for its re-integration back into Aboriginal livelihoods. Resources and implementations such as the aforementioned Education Initiative are but one step for its full realization.

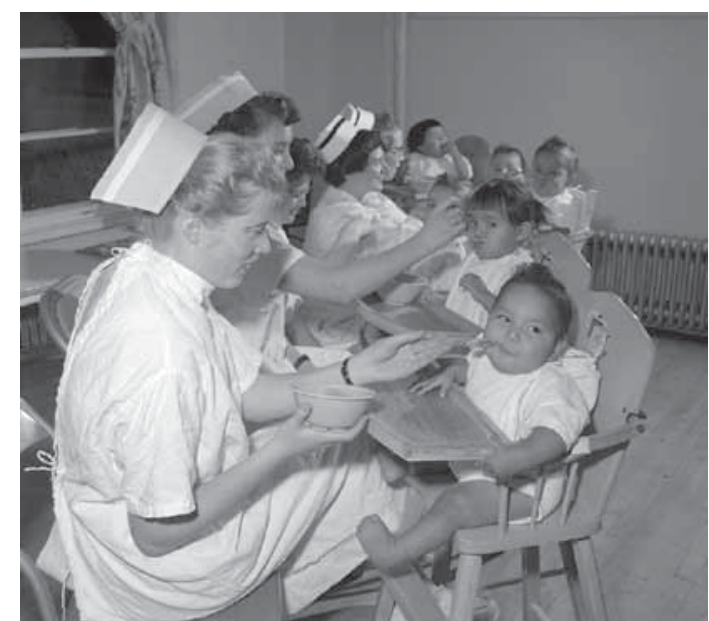

fig. 24. Nurses feed Aboriginal children at the Charles Camsell Indian Hospital. Experiments were conducted on Aboriginals to test the effectiveness of streptomycin in combating tuberculosis. Photograph. October 1958. Image retrieved from http://sciencewriters. ca/2013/10/30/meet-ian-mosby-the-man-whoexposed-canadas-experiments-on-aboriginals/

\section{Winnipeg, Manitoba,}

which has the largest Aboriginal

population per capita in Canada, only a meager $6.9 \%$ of self-identified Aboriginal people are able to speak their native-tongue." 3 - 2012 Statistics Canada Data. 


\section{Representation through Architecture}

The use of architecture and its implementations on how it can serve Aboriginals as both vessel and catalyst for a Voice and Identity was also brought forth. Pointed out by both interviewees, Commissioner Wilson and Darren Courchene emphasized that most of what they have been presented with in the past regarding Aboriginal architecture, was somewhat over-embellished with symbolism, which would often result in a type of gift-shop-architecture, often meant more to appease the public and governing officials. Several examples of First Nations schools and university/colleges were

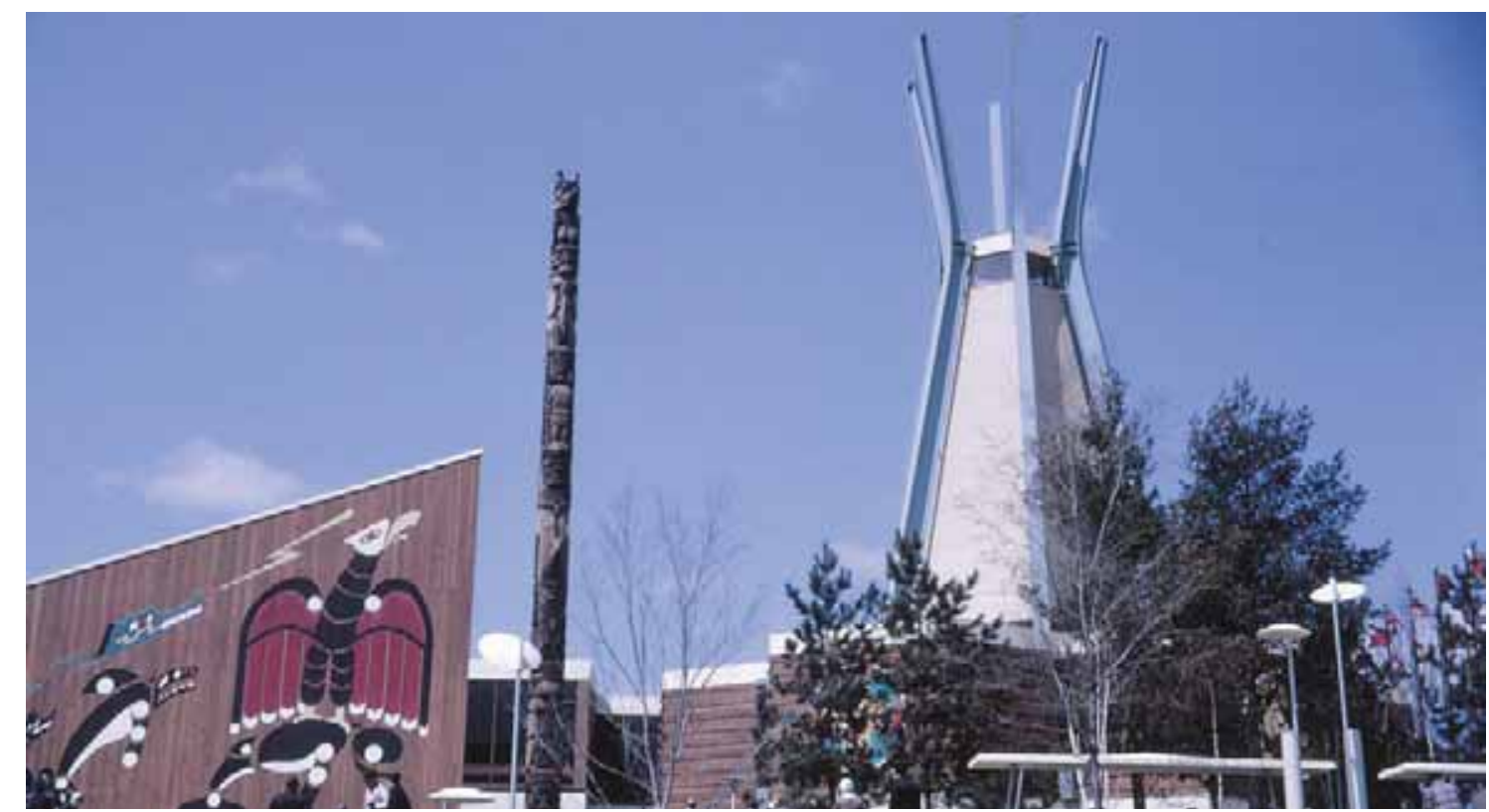

fig. 25. Indians of Canada Pavillion. Montreal, QC. 1967. Image retrieved from http://upload.wikimedia.org/wikipedia/ commons/c/cd/Expo_67\%2C_pavillon_Les_Indiens_du_Canada_\%282\%29.jpg

.. it may look cool, costs way more to build, and it's totally impractical.

You got all these schools now, I was joking and saying that they're shaped like porcupines and crazy stuff, but they're totally impractical. But if you asked the architects, the architects feel good. 'Cause sometimes they'll win awards, right?'... they're winning awards for useless buildings." ${ }^{12}$ 
given, which were designed with some sort of reference to an animal, etc., but were for the greater part impractical in terms of their overall functionality. Courchene pointed out instances where uses of colour were used inappropriately (the colours black and blue), in the wrong context, or an over-glorification of Aboriginal elements (i.e. teepees, and longhouses) as drivers for the architectural form. The inclusion of one particular element, such as a certain colour, will more than likely signify that the design will fail and overlook other aspects of colours not included.

".. it may look cool, costs way more to build, and it's totally impractical. You got all these schools now, I was joking and saying that they're shaped like porcupines and crazy stuff, but they're totally impractical. But if you asked the architects, the architects feel good. 'Cause sometimes they'll win awards, right?... they're winning awards for useless buildings."12

Both Commissioner Wilson and Courchene pointed out that simplicity could go a long way in terms or representing Aboriginals and their values. Simplistic introduction of some elements of nature (sun, sky, earth, etc) was a re-occuring theme with Courchene, and further supported by the Commissioner.
As the conversations were drawing to an end, a deeper empathy and understanding of their community's struggles, values, beliefs, and affairs had become apparent - their voice demands equal treatment at the conversation tables, nothing more, nothing less. Perhaps in keeping with tradition, the Commissioner offered me a book Bounty and Benevolence: A History of Saskatchewan Treaties - as a gift to help further my investigations and research; their generosity was and still is gratefully acknowledged. $\infty$ 


\section{Endnote.}

01. Robertson, Jesse. Uncomfortably Canadian. Website. Oct. 15, 2012. Accessed Dec 26, 2014. http://uncomfortablycanadian.wordpress. com/2012/10/15/john-ralston-sauls-metis-country/

02. Treaty Relations Commission of Manitoba. Website. About Us Commissioner's Biography. Accessed Mar. 07, 2015. http://www.trcm.ca/ about-us/commissioner/treaty-commissioners-biography/

03. Statistics Canada. 2012. Winnipeg, Manitoba (Code 4611040) and Division No. 11. Manitoba (Code 4611) (table). Census Profile. 2011 Census. Statics Canada Catologue no. 98-316-XWE. Ot Pro. Released Census. Statictics Canada Catogue no, 98-316-XWE. Otawa. Released October 24, 2012. Accessed December 20, 2014 htps./Mwww12.statcan. gc.ca/nhs-enm/2011/dp-pd/prof/details/page.cfm?Lang=E\&Geo

$=$ CSD $\&$ Code $1=4611040 \& D a t a=$ Count\&SearchText=winnipeg\& SearchType=Begins\&SearchPR=01\&A1 =All\&B1=All\&Custom $=\& T A B \mid D=1$ 04. Wilson, James and Darren Courchene. Interviewed by Jagtar Singh. Conversation with the Commissioner. Winnipeg, MB. 18 December 2015. pt.1 - 2:10 mins.

05. Ibid. pt. 1 - 03:30 mins

06. Ibid. pt.1 - 04:45 mins.

07. Ibid. pt. 1 - 06:40 mins

07. lbid. pt. 1 - 06:40 mins
08 . lbid. pt. 2 - 00:30 mins

09. Ibid. pt. 3 - 05:35 mins.

10. lbid. pt. 3 - 15:15 mins.

11. Ibid. pt. 2 - 05:00 mins.

12. lbid. pt. 2 - 17:00 mins.

3. Ibid. pt. 3 - 18:20 mins.

14. Ibid. pt. 2 - 19:11 miins. 

Silenced Narrative:

Postcard Series
During the early to mid 20th century, many department stores, including The Hudson's Bay Company, would often have for purchase their own postcards. These postcards would often feature their departments stores, or other prominent buildings from their respective cities.

The intent was that the many rural families visiting both the city and their stores would purchase them, and send them to family and friends back home to show them the splendors of the great and developing cities, with hopes of attracting them to come see the department stores themselves.

The Postcard series created for the intend of this thesis were used as a critique to the research and investigations which were being carried forth. Many of the postcards represented are of a political satire cartoon nature. 


\section{Native}

Original

oil

painting

Ron Rundo. The image is overlaid with the Hudson's Bay Company Point Blanket's band colours. On first impressions we notice the yellow band is missing. But what we often fail to recognize is the Aboriginal's ability to voice their narrative.

1.http://www.atkinsonfineart.com/ltemHome. php?ltemiD=1281

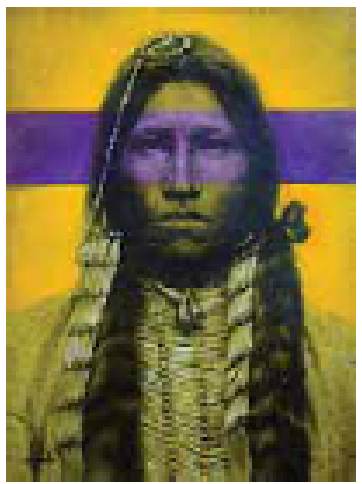

Original

painting

(left) Native

American by

Ron Rundo.

Oil on Canvas.

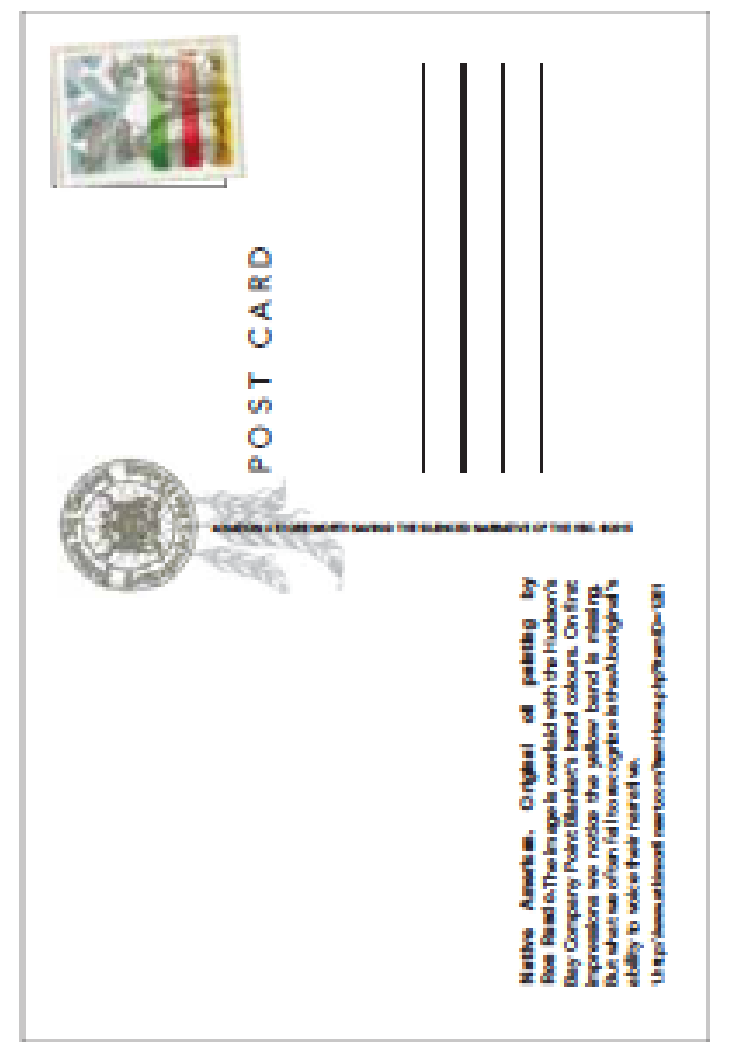

BACK
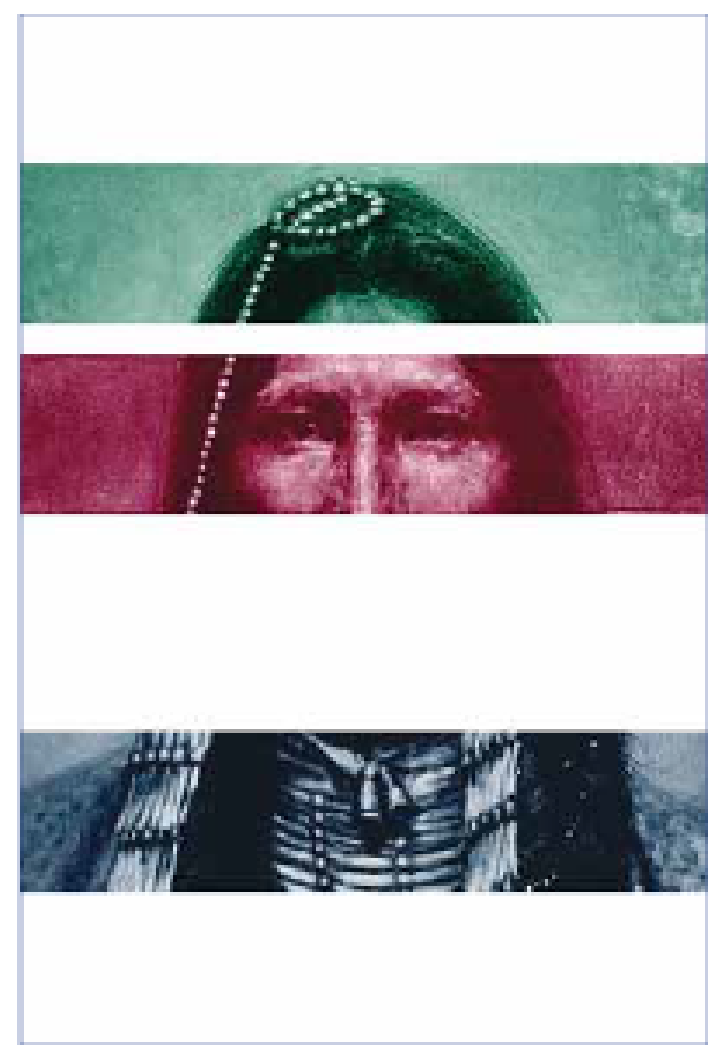

FRONT 


\section{Single-Handed, Charles Marion}

Russell 1912. The painting depicts a Northwest Mounted Police officer attempting to arrest a defiant First Nations warrior at a Blackfoot camp, somewhere in Alberta or Saskatchewan. ${ }^{1}$ First impressions of the painting invoked a sense of robbery and bullying by authority, which is all common today; hence the new caption.

1.http:J/en-wikipedin_org/nikiWWikipedie:Featured_picture_candidaten/Single-Handed

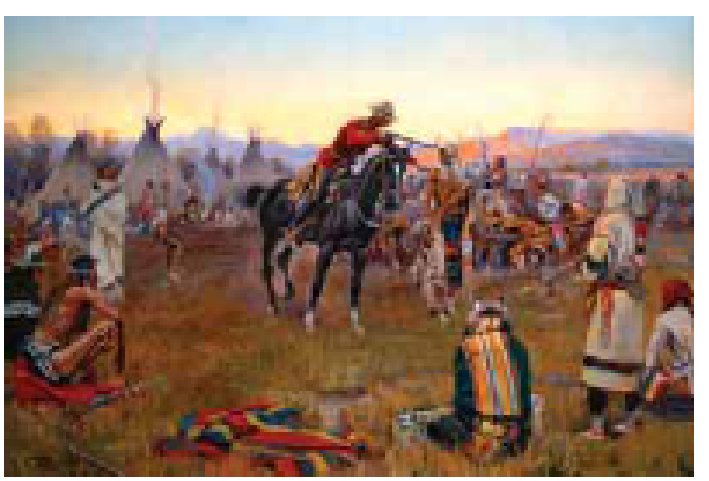

FRONT

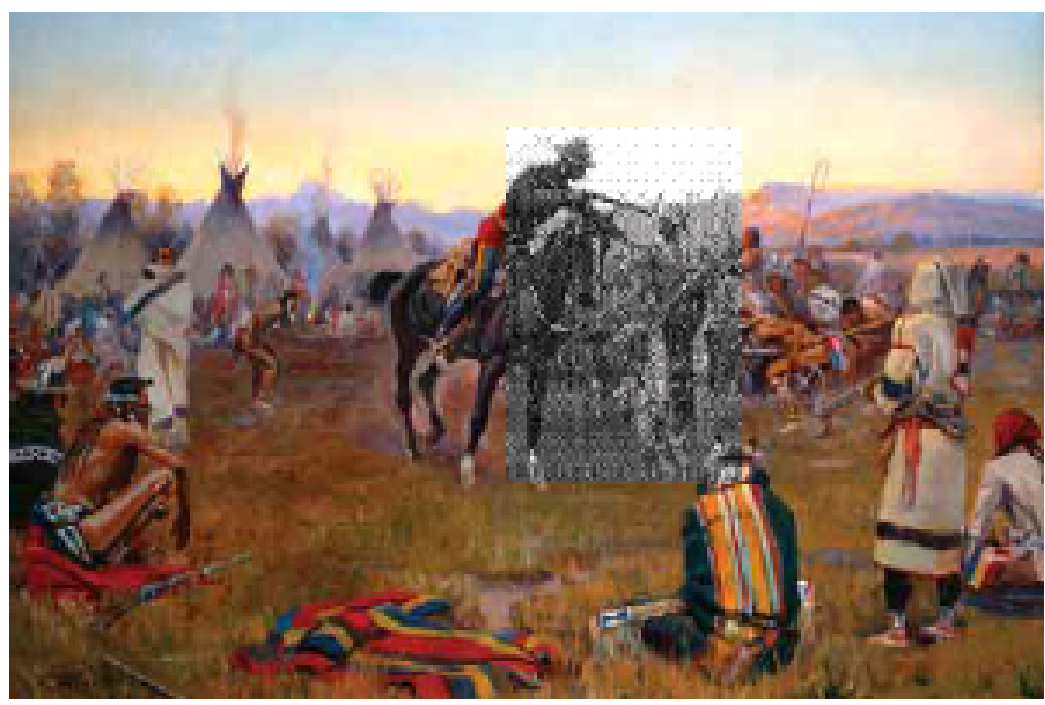

Original painting (left) Single-

Handed, Charles Marion Russell

1912.
BACK

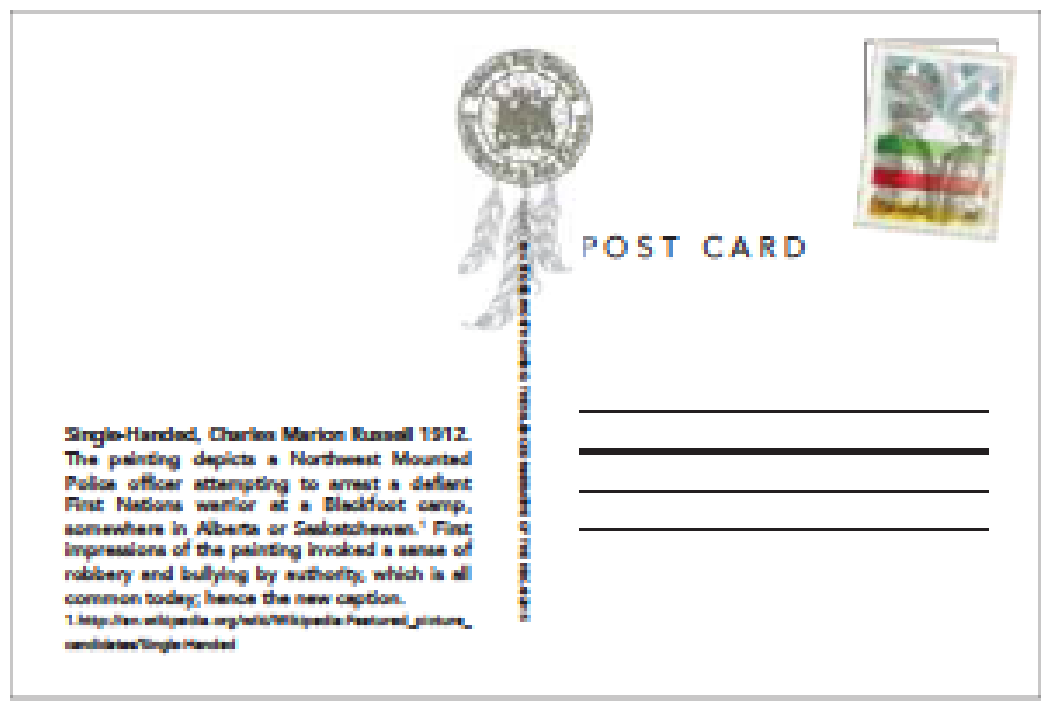


Louis David Riel. Louis Riel was both

a politician and spiritual leader for the Métis people of the Prairies and rest of Canada. He led 2 resistance movements against the Macdonald government. Riel sought to preserve the Métis rights and culture, as it was under progressive attack. ${ }^{\prime}$

1.tlp//enwikipedia.org/wik/Louk_fie

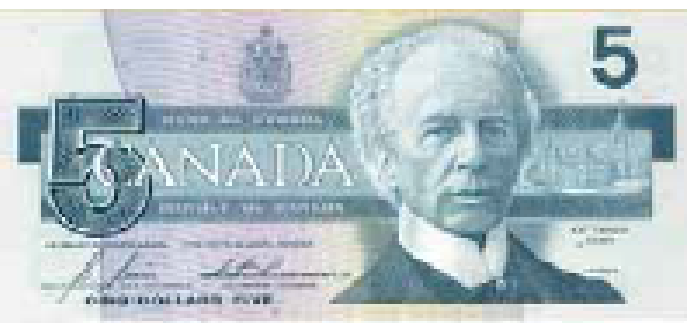

FRONT

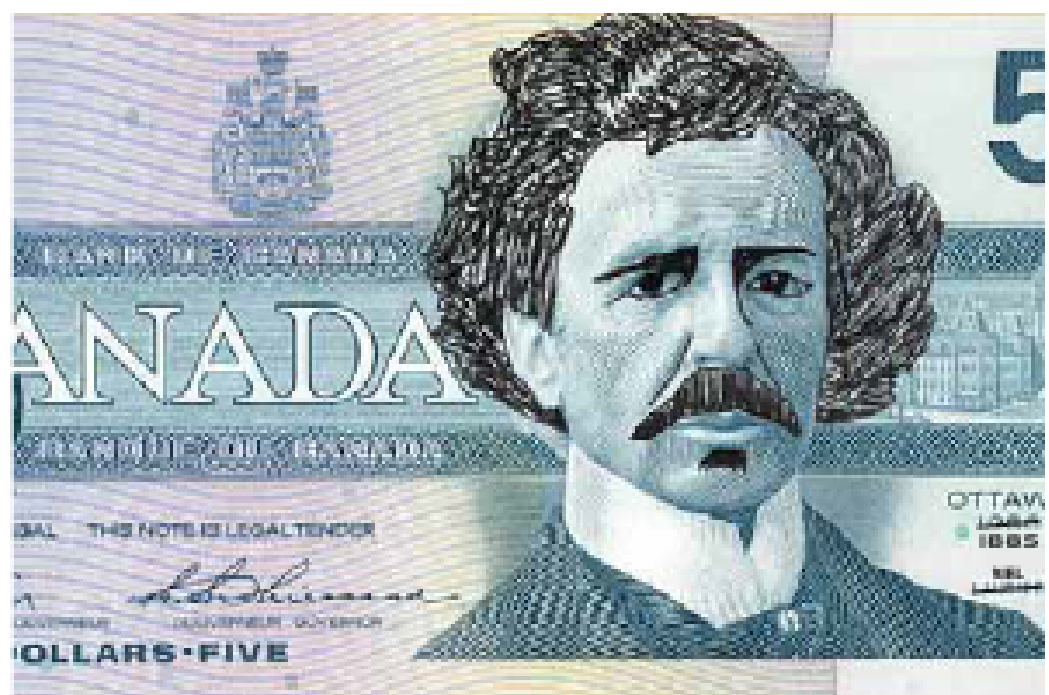

BACK

Original image

(left) Five dollar

Canadian Bank

Note with Prime

Minister Wilfred

Laurier. 1986.

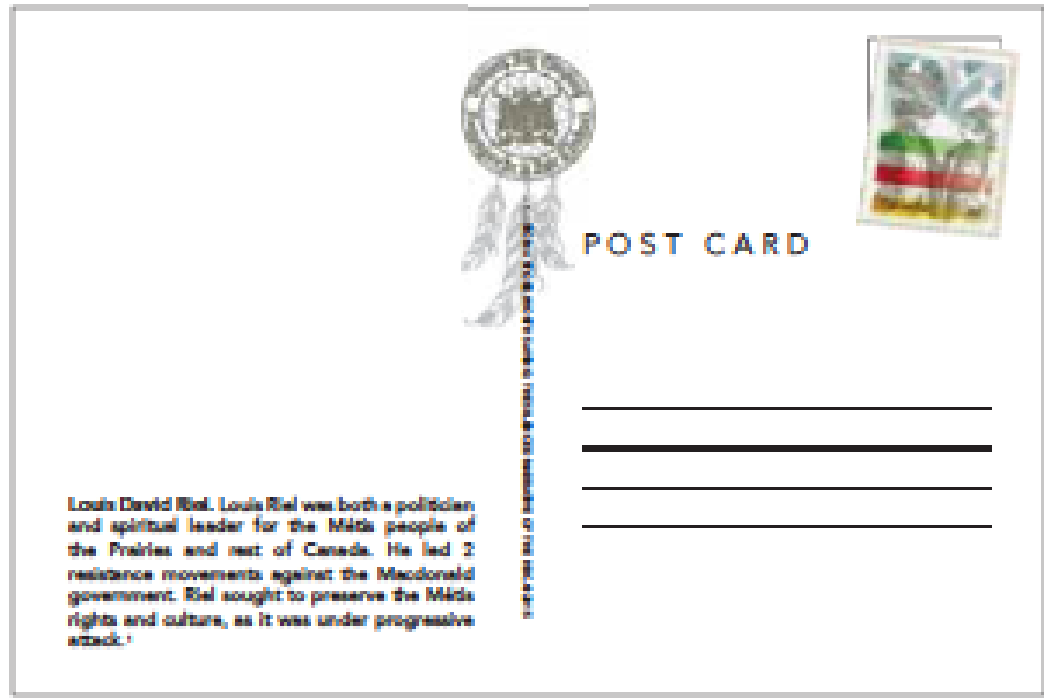




\section{John A. MacDonald 'Stickem-up'.}

During the the Red River Rebellion,

Prime Minister John A. Macdonald deeply opposed Métis leader Louis Riel's views, and was key to Riel's sentencing and 1885 execution. Riel was both a politician and spiritual leader for the Métis people of Canada.' The image depicts Macdonald robbing Aboriginals of their voice, rights, and identities.

1.ttp//enwikipedia.org/wikh Loub_fiel

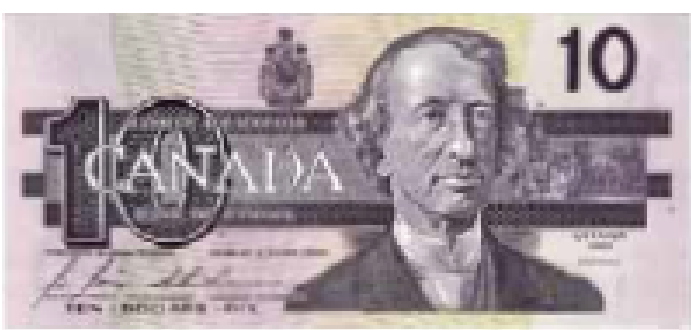

FRONT

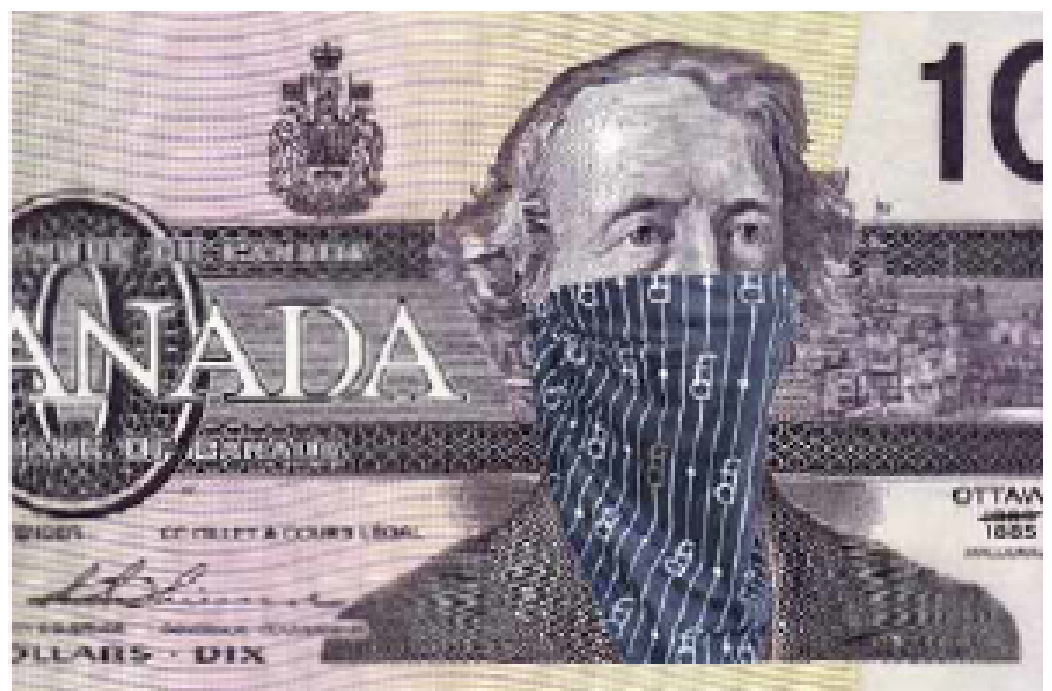

BACK

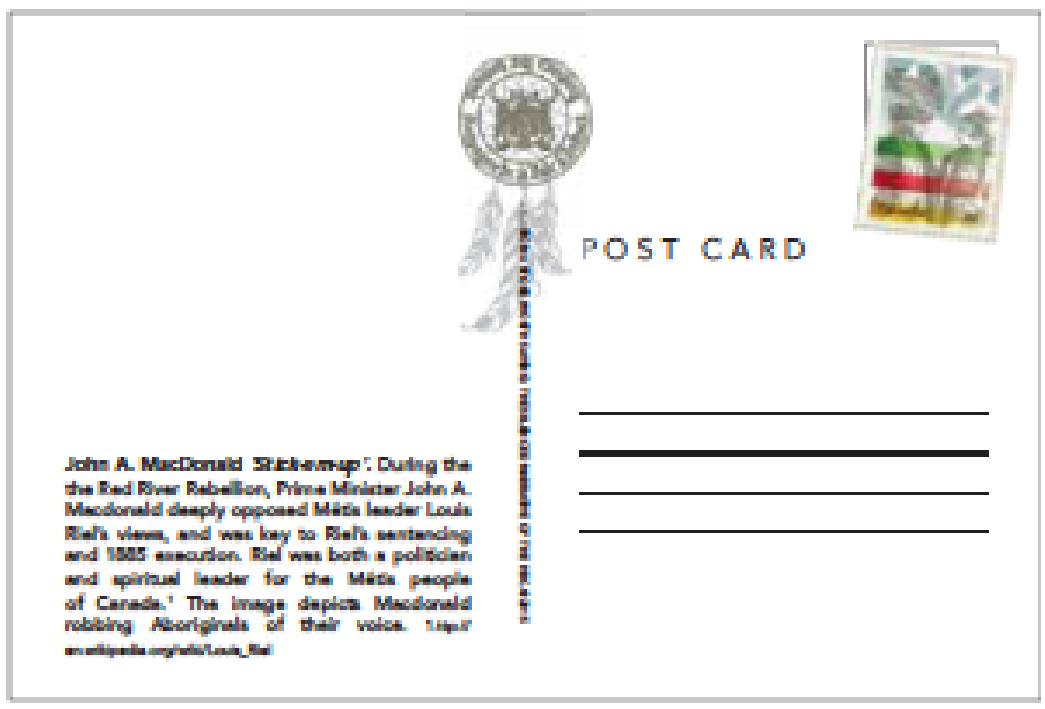

Original image (left) Ten dollar Canadian Bank Note with Prime Minister John A. MacDonald. 1989. 


\section{Queen Elizabeth II 'Sheep in}

Wolf's Clothing'. The Indians

of Canada Pavilion at Expo'67, afforded Aboriginal people at the time architecture as a vessel to voice their struggles. The Queen's visit to their pavilion was short lived. British Monarchy has rarely given Aboriginals a private audience, let alone an ear.

1.htpo//enwikipedia.org/wiknndiens_of_Canade_Pavition

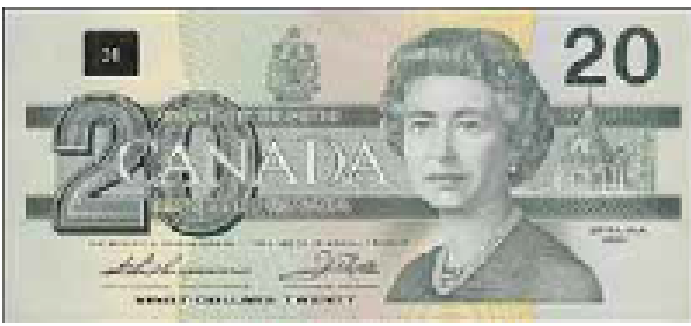

FRONT

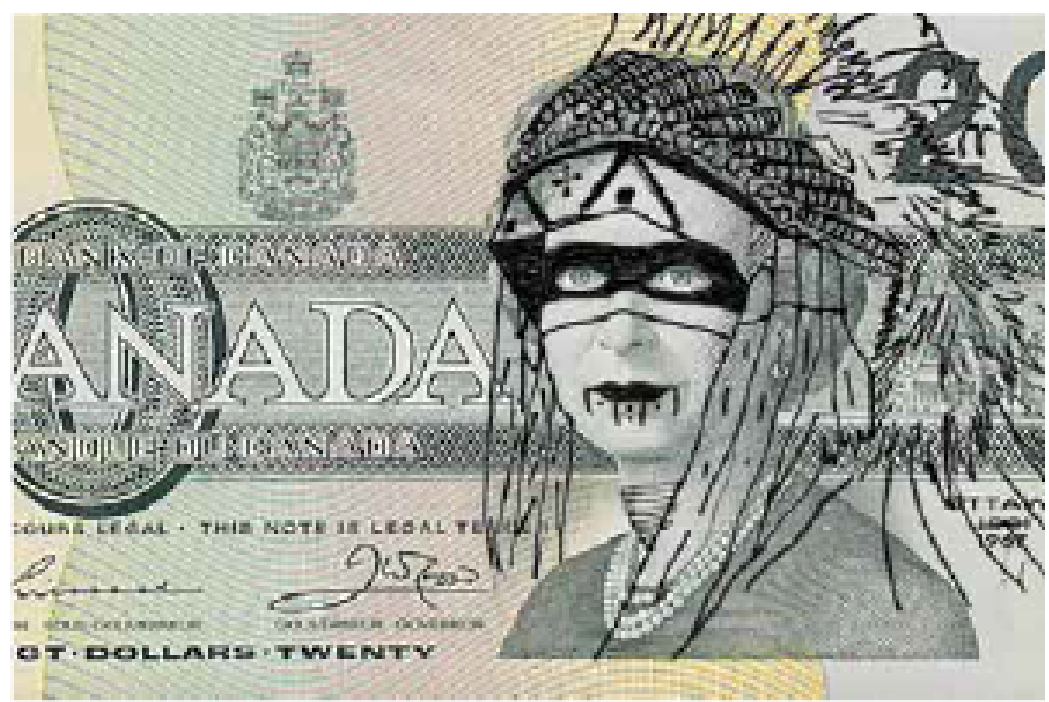

BACK

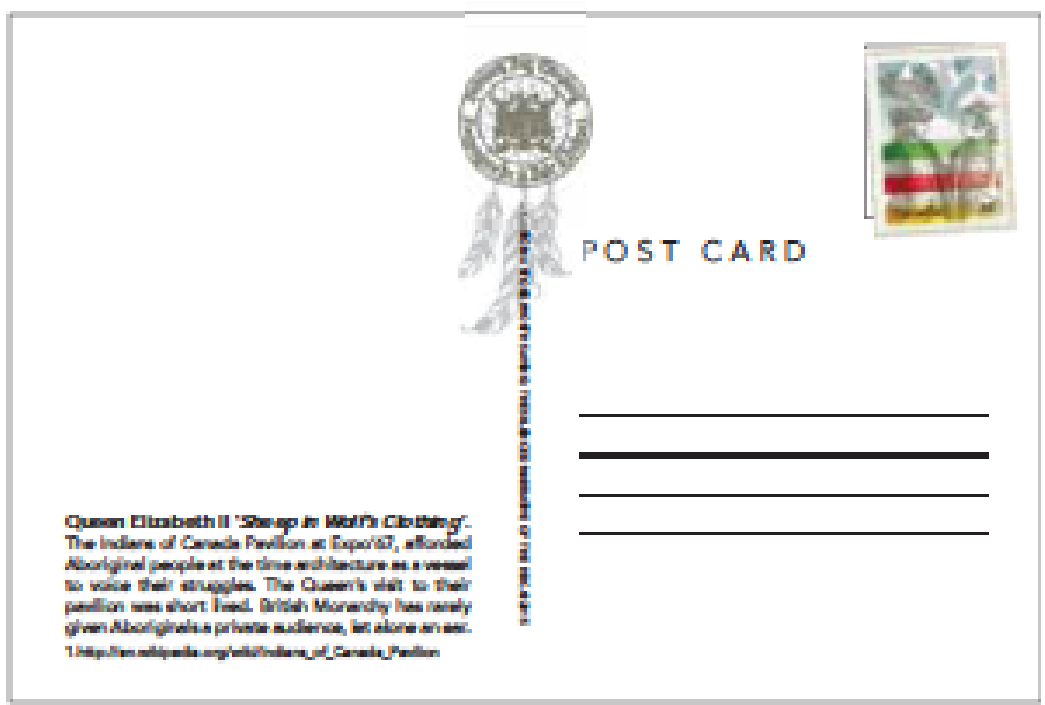

Original image (left) Twenty dollar Canadian Bank Note with Queen Elizabeth II 1991. 


\section{RED marks the Spot. As an} audacious move, red also serves as reminder of what transpired throughout Aboriginal's contact, partnerships, and colonization between them and Europeans. An Aboriginal individual within the Manitoba Justice System had recounted to me several years ago that in his community, when an individual commits a crime against the community that is of a heinous and reprehensible in nature, the community used to mark the individual by skinning a portion of their nose - *Lest we forget.

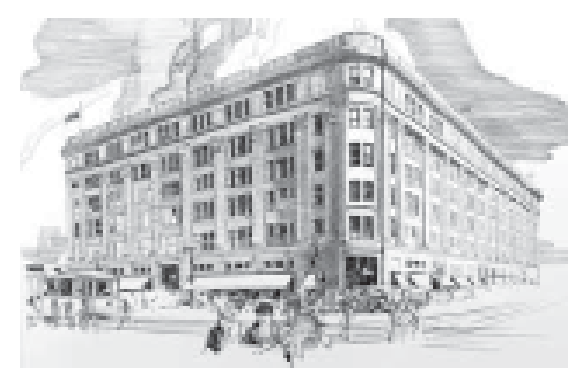

FRONT

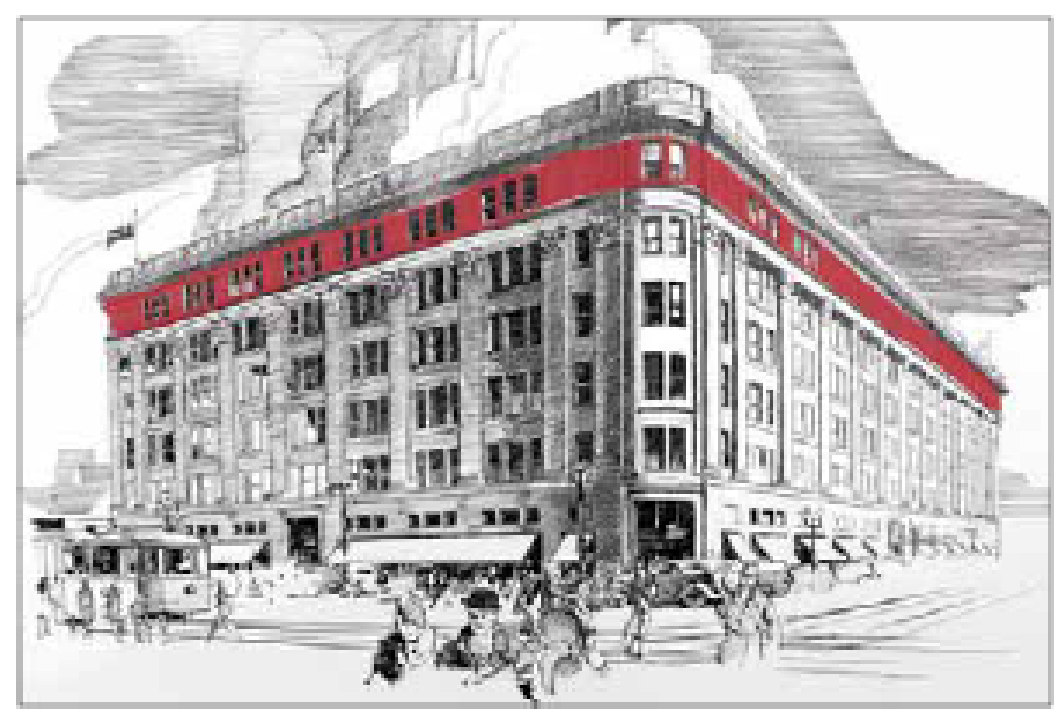

BACK

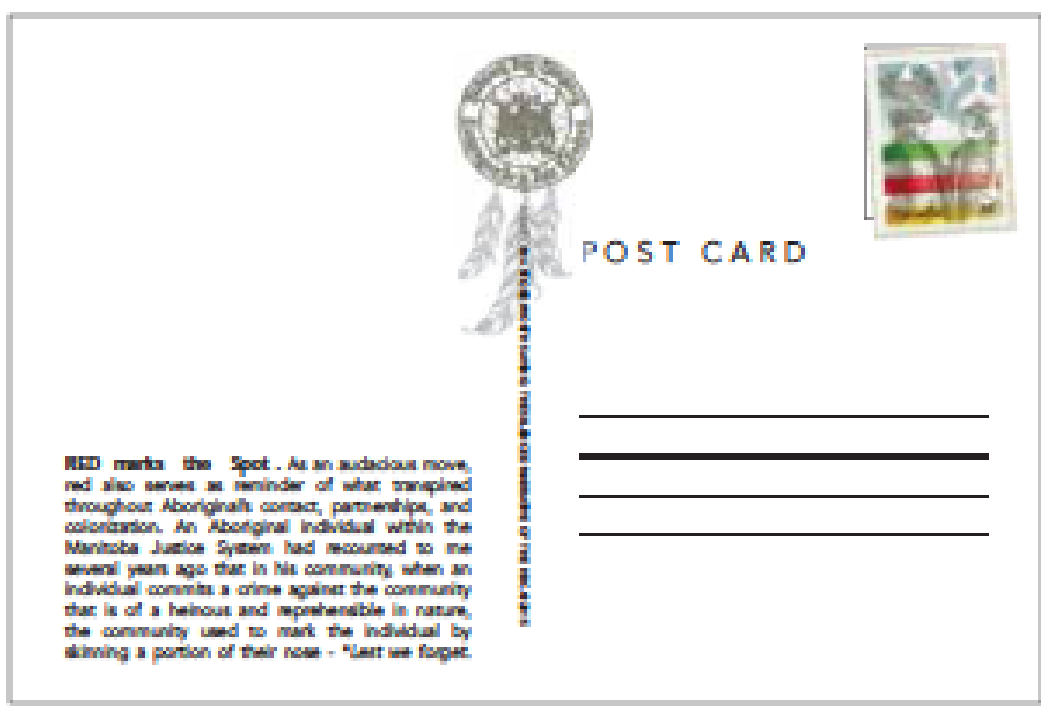

Original image (left) Artist's

conception of Winnipeg HBC store. 1987/363 W - 315/79. 
The Site. Part Two

The Hudson's Bay Company in Winnipeg + Manitoba 78

The Hudson's Bay Company: The Department Store 92 


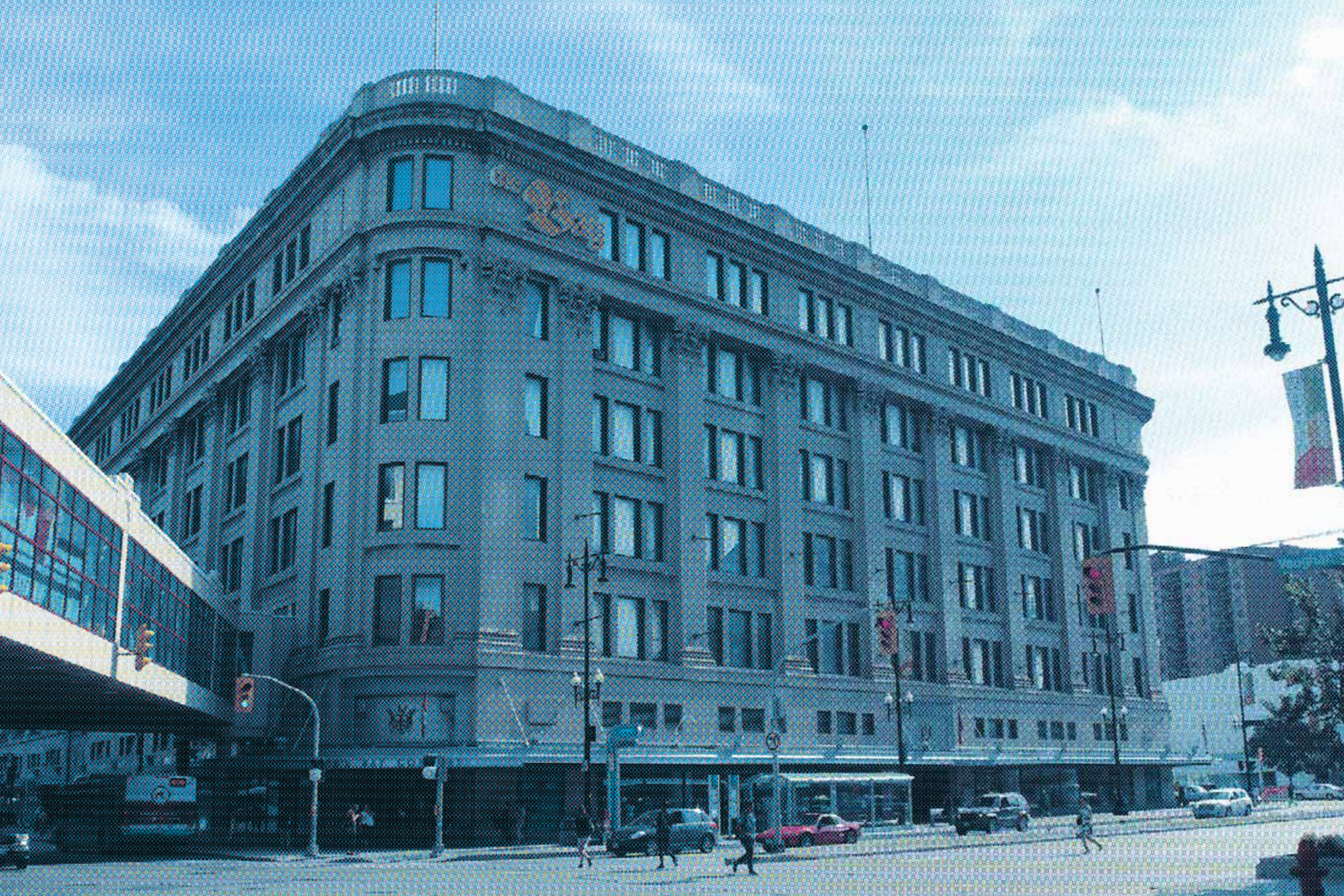

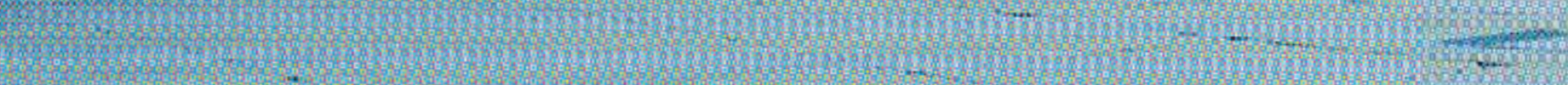

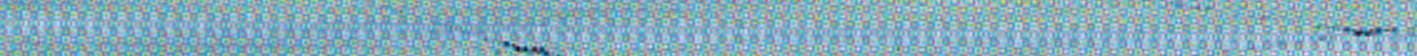


CHAPTER 4

The Hudson's Bay Company

in Winnipeg + Manitoba

"... an oasis in the desert... a spot upon the moon, or a solitary ship upon the ocean." - R.M. Ballantyne, British author and clerk for The Hudson's Bay Company at Red River; when describing The Forks site in the early 1820 .

The Hudson's Bay Company's (HBC) relationship to both the province of Manitoba, and the city of Winnipeg is immensely profound, with The HBC spanning throughout both of their existences entirely. Beginning as an important transportation route, the convergence between two distinct cultures, a thriving trade network, and eventually become the site of where Treaty 1 was both negotiated and signed $^{1 a}$, Winnipeg has since become a rich cultural urban environment; with Aboriginal people still an important pillar in its formation and continued growth. However today, The HBC's influential role has been somewhat dormant, or else non-existent to many of Winnipeg's citizens - other than its physical presence in a suburban mall. To understand $H B C^{\prime}$ s significance and impact on both Winnipeg, and Manitoba, a brief background of their origins and relationships will be needed to gain a better 
understanding of this rebelliousmulti-layered city and province.

From an early fur trading company, a multitude of trading posts across North America, explorations of the frigid Arctic, the establishment of some prominent western Canadian townships and cities ${ }^{2}$, and to now a thriving retail empire, The Hudson's Bay Company (HBC) has not only played an "instrumental role in the history of Canada and North America" ${ }^{3}$, but has also become the facet in which many Canadians identify themselves with. The HBC has inevitably played a significant and influential role into both the nation's architectural scene, and the city of
Winnipeg, Manitoba - their impact is evident across Canada.

By the mid-nineteenth century (1838), The HBC had situated itself along convergences of the Red and Assiniboine Rivers - now known as the site of the Forks - with the construction of Upper Fort Garry (not to be mistaken with Lower Fort Garry some 30 miles south along the Red River, which The HBC also occupied). The scant settlement of the area comprised mainly of mixed Europeans and Aboriginal ancestry, retired HBC employees, active fur traders, and Aboriginals - this first group was known as the Red River Settlement. ${ }^{4}$
During this time, the site of The Forks was becoming a significant agricultural and trade settlement site, with some nearby forts and commercial buildings. Land granted by Sir Walter Scott - whom was the fifth Earl of Selkirk, and a major shareholder in The HBC - allowed Scottish settlers to establish the numerous narrow farm plots in and around The Forks; the population a mere 5,000 inhabitants. ${ }^{4}$ Although inhabited by few, this settlement was also becoming a vibrant social hub, in which Alexander Ross (Red River Colony historian at the time) described the site as a "lively and attractive station, full of business 
and bustle. Here all the affairs of the colony are chiefly transacted," 4 .

For the remainder of the nineteenth century, The HBC would safeguard its trade monopoly throughout the region. Roman Catholics, Anglicans and Presbyterians would also benefit and begin to establish both its educational and religious edifices. ${ }^{5}$ Overseas in London, England; the Parliament Government was keeping a close eye of the river-settlement, but were also in the process of combining various parts of their land ownerships, to negotiate for the surrender of these land-deeds to the Dominion of Canada, which included the Red River Settlement. Between 1857 and the early 1860s, the Red River Settlement would see a significant increase of immigrants arriving east from the Dominion of Canada, eventually leading to the formation of the "Canadian Party". It was in 1859, that the party would see some momentum with the additions of two British-born journalists, William Coldwell and William Buckingham. The two journalists would setup the colony's first print shop and newspaper: the Nor'Wester. ${ }^{6}$

The duos first print edition of the Nor'Wester in December 1859, would go on to advise the river-settlement that they were all

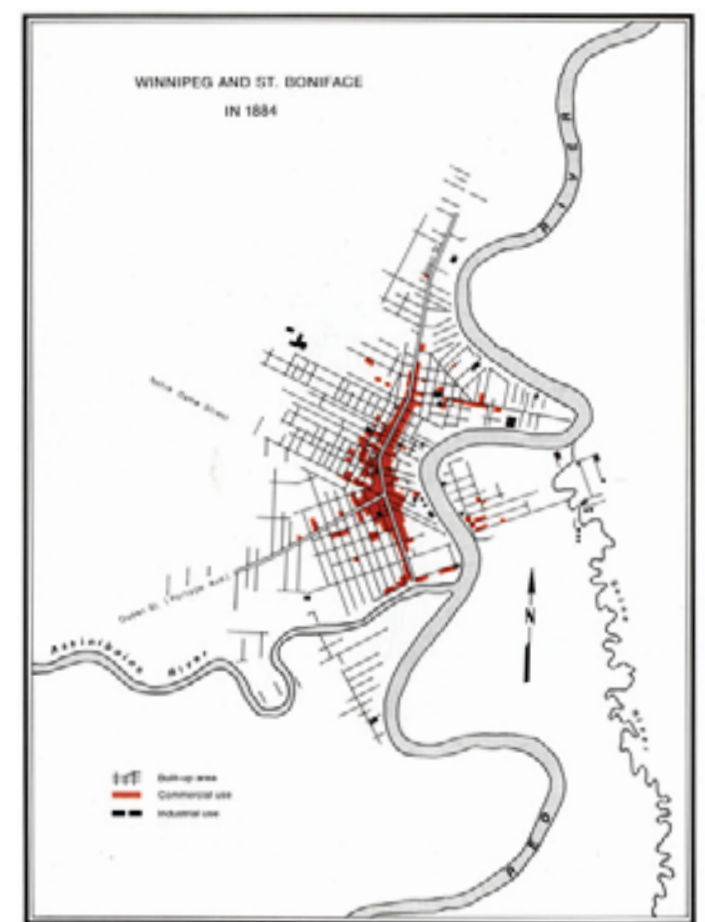

fig. 27. 1884 Map of Winnipeg and St. Boniface. Thomas. R Weir. 1912. Print. Atlas of Winnipeg. Toronto ON: University of Toronto Press. 1978. 
basically " "living in a miserable state of serfdom' under the Hudson's Bay Company rule" 6 , and their salvation would be found with the union of the Dominion of Canada - the Red River Settlement remained unimpressed. During this time, a few shanties settled around the outside walls of Fort Garry, but nothing resembling a township; the Nor'Wester continued its plight. By July of 1867, the Dominion of Canada had already acquired a vast amount of territory, with the exception of two colonies in eastern-British North America, as well as the Red River Settlement. ${ }^{7}$

By now, negotiation talks were both occurring and concluding between the Imperial Government in England, the Dominion of Canada, and The HBC - this included the acquisition of the Red River Settlement by the Dominion of Canada in a $£ 300,000$ plus a multiple land concession deal from The HBC. Back east, many of the Red River Settlement - whom of which were *Métis - viewed themselves as a " 'new nation,' a 'a peculiar people,' "8 and were angered by negotiation talks as they were unsurprisingly never consulted. The persistent push for the Dominion of Canada's land acquisition of the Red River Settlement resulted in the stream of people arriving at the colony. With

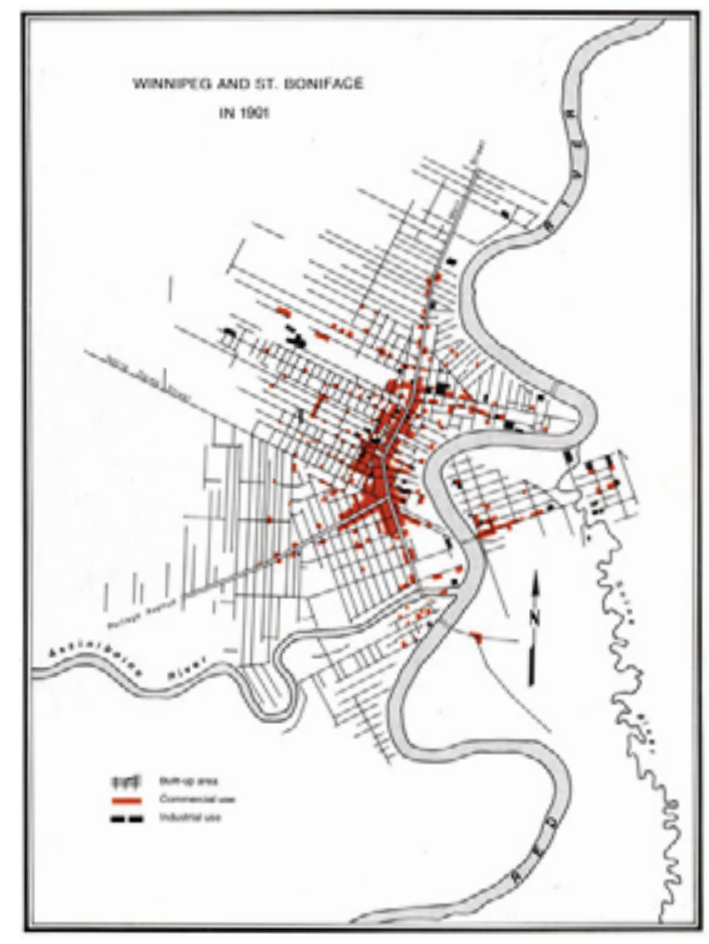

fig. 28. 1884 Map of Winnipeg and St. Boniface. Thomas. R Weir. 1912. Print. Atlas of Winnipeg. Toronto, ON: University of Toronto Press. 1978. 
the arrival of people, also came new visions and ideas of civilization and its progress; many of which were not favorable by the colony's already established Métis people.

During the late 1860s, Louis Riel had become the political face for Métis people of the Red River Settlement, despite his absence from the settlement for nearly ten years (he did however keep up to date with its current events). Riel would follow in his father's footsteps - whom fought the free-trade against The $\mathrm{HBC}$ - and despite being only somewhat partially Aboriginal, he considered himself very much Métis. In around 1869, the Métis people of the colony would form an alliance named the National Committee, with Riel eventually its leader. ${ }^{9}$ Riel and its Committee would go on to seize Upper Fort Garry - The HBC's

"... symbol of power in the Northwest. The stone fort was the social focal point of the Red River and served as the home of the $\mathrm{HBC}$ governor. More importantly, Fort Garry was the centre from which all settlement roads radiated. Whoever controlled the fort could control movement within the Red River Settlement. Riel wanted to ensure neither Mc Dougall [sent to Red River settlement to become the Lieutenant Governoron behalfofthe Government

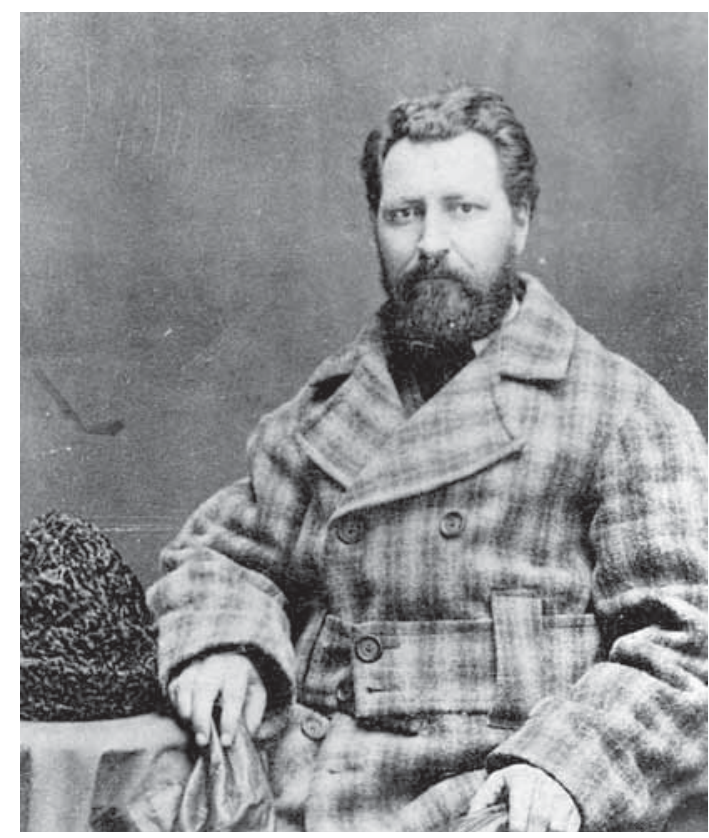

fig. 29. Métis political leader Louis Riel. Photograph. Baldwin. 1878. University of Manitoba Library Archives. PC 107.

The declaration [by Louis Riel] stated that the Hudson's Bay Company had abandoned the people to a 'foreign power,' without their consent." 12 - Christopher Dafoe. 
of Canada] nor the local Canadians would win this strategic advantage."10

At the end of 186912, Louis Riel and his National Committee had now taken control and overthrown the settlement, they now had the attention of both England and the Dominion of Canada. The Red River Rebellion was thus underway, and in full momentum.

"The declaration [by Louis Riel] stated that The HBC had abandoned the people to a 'foreign power,' without their consent."12

By now, Louis Riel and his provisional government had the attention of Ottawa, and more notably Prime Minister John. A. Macdonald, whom of which sent diplomats to the Red River Settlement, not exactly to negotiate, but "were sent simply to gather information." 12 In a letter from December 13, 1869, Prime Minister Macdonald writes:

"'Smith goes to carry the olive branch... We must not think of military force until peaceable means have been exhausted. Should these miserable half-breeds not disband, they must be put down, and then, so far as I can influence matters, I shall be very glad to give Colonel Wolseley the chance of glory and the risk of the scalping knife.'"13

Through various negotiation and bribery tactics by the Dominion

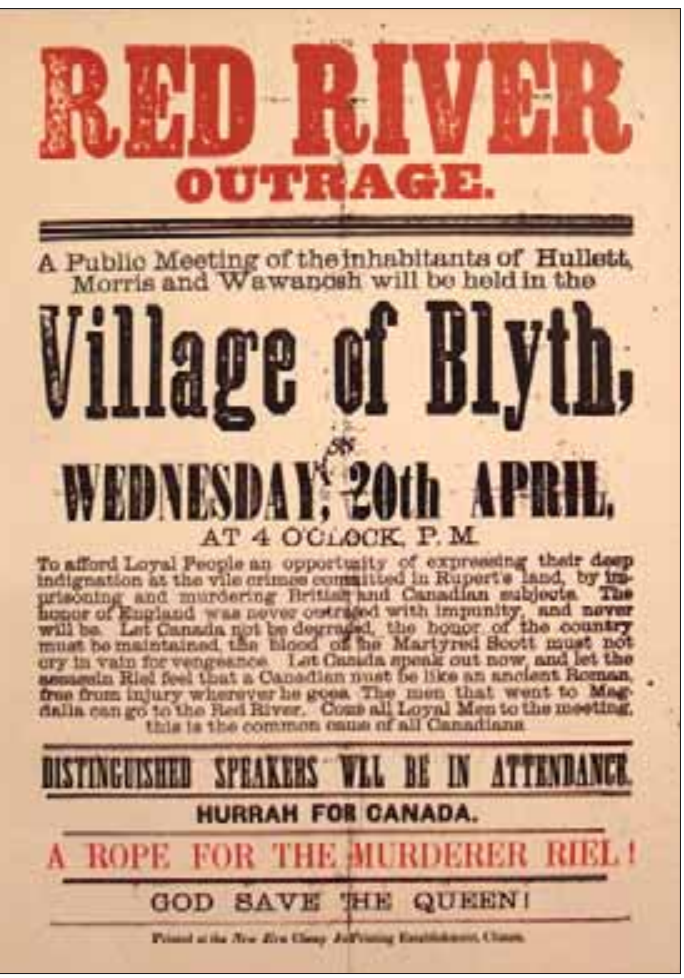

fig. 30. Reaction in Ontario to Scott's execution Photograph. A History of Manitoba: Volume One - Rupert's Land to Riel. Winnipeg, MB: Great Plains Publications, Ltd. 1993. 
of Canada diplomats, no agreement was reached between Louis Riel and John A. Macdonald. Feeling at a loss, and an attempt to reassert his authority, in 1870 Riel would execute Thomas Scott - land surveyor of the Dominion of Canada - "setting off the sequence of events that would eventually defeat his cause." ${ }^{14} \mathrm{On}$ August 21, 1870, Canadian troops entered the fort where Louis Riel and his provisional government were, and re-established control. Riel had since fled the settlement only days before, and was now seeking refuge in the United States - this event marked the end of Riel's Government and their Rebellion. Eventually Louis
Riel returned to Canada, where he faced charges for the murder and high treason of Thomas Scott. On November 16, 1885 Louis Riel was executed by hanging ${ }^{14}$.

Surprisingly noted throughout most of the research conducted, is The HBC's censorship of these monumental blood-spilling events in their tell-all book The Hudson's Bay Company by Assouline Publishing. Their book paints a surreal self-image, with little to no reference of Louis Riel or the Métis political movement that was opposed to the $\mathrm{HBC}$ transferring its land deeds, which included Winnipeg and Manitoba, over to the Dominion of Canada. If today, Canada were to begin negotiation talks with the United States for the transfer over of several of its provinces, we would be reluctant to find anyone in complete favour of entertaining such idea without obstruction. 
Land, Infrastructure, and Retail

By the 1870s, the fur trade industry had concluded and The HBC would respond by shifting its efforts and resources to land sales and to its general and small retail stores, which were becoming much more profitable. The following fifty some years, The HBC would increase its retail store presence across the country, allowing it to later become one of Canada's leading department retail stores.

Though often known for their fur trade business, and more notably their retail operations today, the HBC's business ventures also included the real estate and

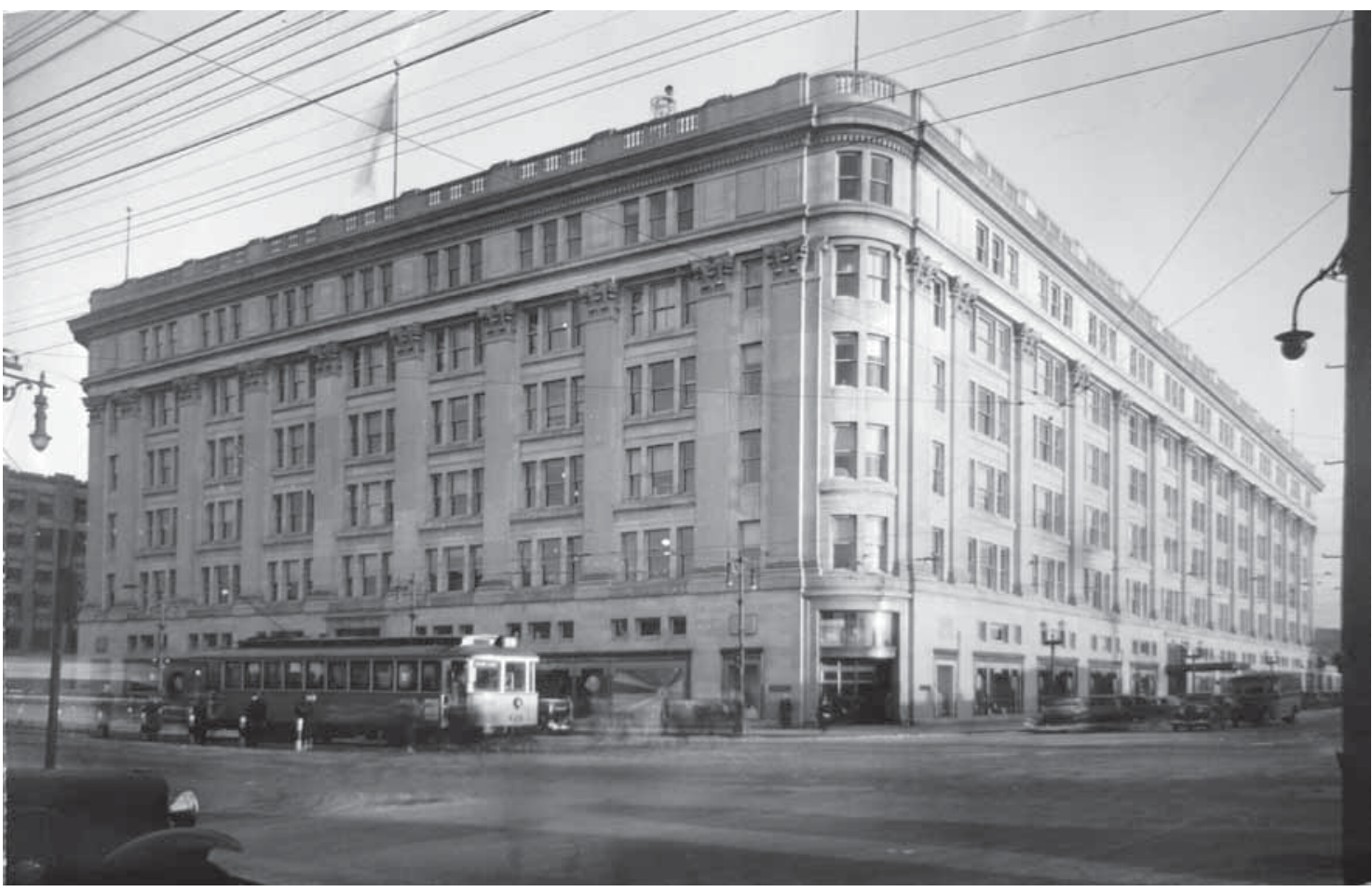

land development during the

fig. 31. The HBC Winnipeg department store Photograph. HBC Archives Collection. HBCA 1987/363 W-315/82

nineteenth and twentieth centuries.

In Winnipeg, Manitoba, the HBC began their real estate undertaking with the 1869 Deed of Surrender. The 1869 Deed of Surrender affecting $\int$... the Company's traditional grandeur revealed itself in the expansion and lavish outfitting of its western department stores.” ${ }^{17}$ 
Winnipeg was part of the HBC's land ownership (Rupert's Land) transfer over to the Dominion of Canada this consequently resulted in the Red River Rebellion by Louis Riel mentioned earlier. In return for the land transfer, the $\mathrm{HBC}$ would receive a considerable amount of monetary compensation and a "... percentage of townships lots across the western fertile belt, mineral rights and land holdings surrounding each $\mathrm{HBC}$ post. This amounted to 450 acres around Upper Fort Garry that was known as the HBC Reserve." 18 This land reserve occupied a significant portion of the city of Winnipeg when the city was incorporated shortly after in 1873.

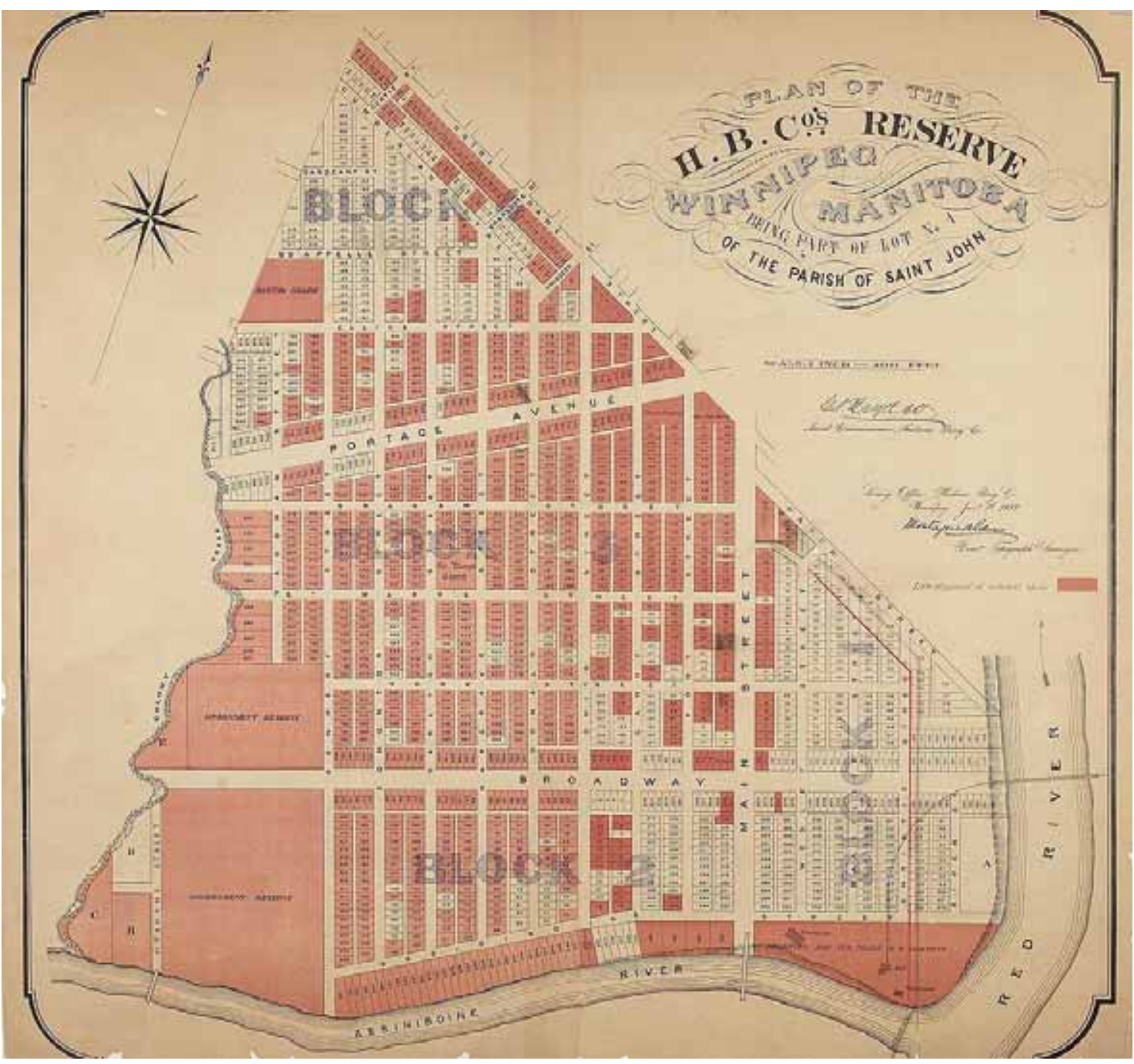

fig. 32. 1887 Map showing area of HBC Reserve. Site of the Forks. Winnipeg, MB. E-000007937 Library and Archives Canada 
And because the HBC owned such a large portion of land within Winnipeg, this resulted in a considerable amount of taxes paid - $\$ 595,312$ to be exact - which played a considerable role in the city's infrastructure development and improvements ${ }^{18}$.

Now being a significant stakeholder in the city of Winnipeg's landownership and development, the HBC had now also become an important influence in the city's infrastructure planning and development. In 1881, the HBC would set forth to design and build several bridges ${ }^{19}$ - the Broadway Bridge, designed by Edward Worrell Jarvis ${ }^{20}$; and Red River and
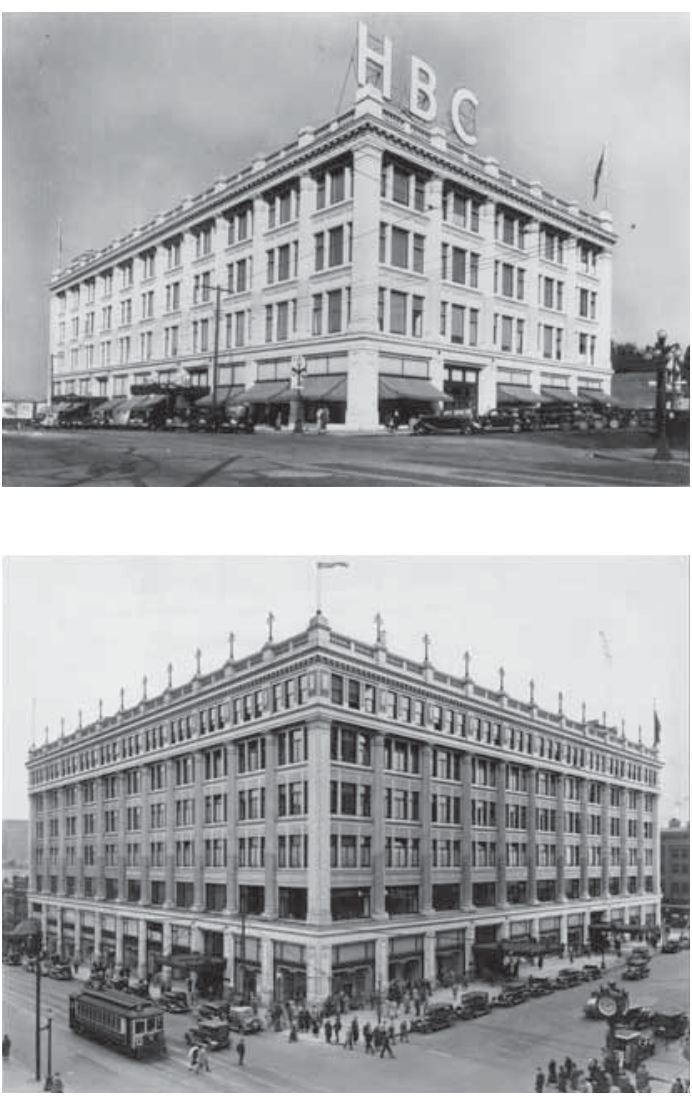

fig. 33. (above left).

The HBC Victoria department store. 1921. Photograph. HBC Archives Collection.

HBCA 1987/363-V-25/9

fig. 34. (below left).

The HBC Vancouver department store. 1914. Photograph. HBC Archives Collection. HBCA 1987/363-V-115/10
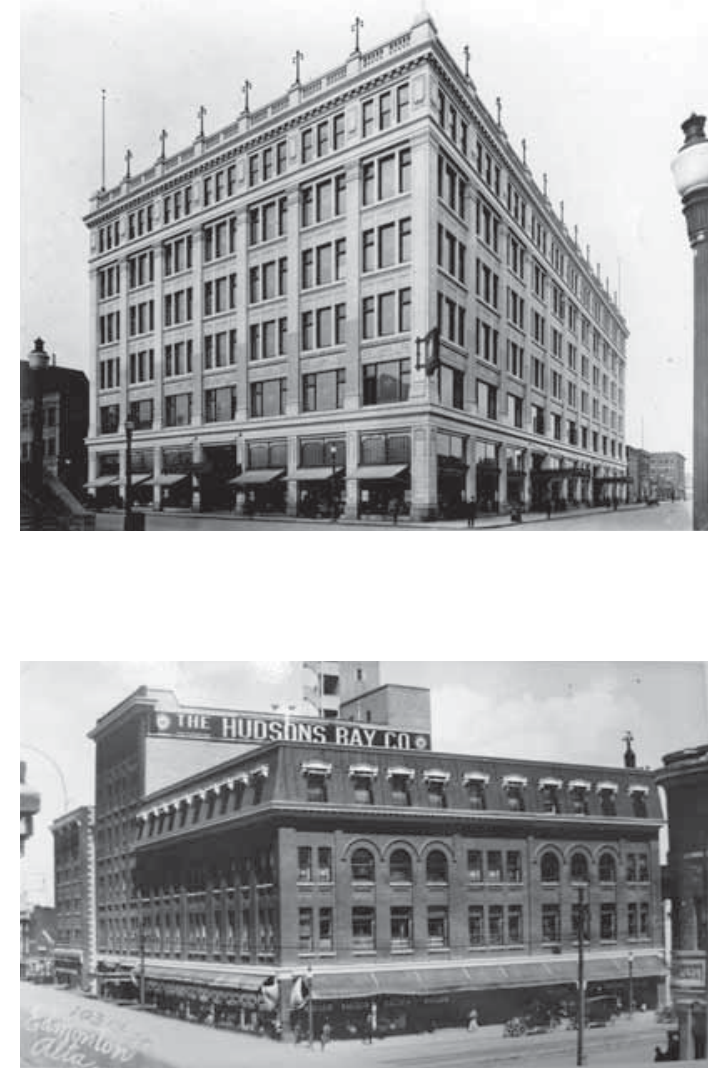

fig. 35. (above right).

The HBC Calgary department store. 1913. Photograph. HBC Archives Collection.

HBCA 1987/363-C-213/11

fig. 36. (below right).

The HBC Edmonton department store.

1913. Photograph. http://www.hbcheritage.ca/ hbcheritage/history/timeline/early/home 
Assiniboine Bridge Company, which was a subsidiary company of the HBC that built Winnipeg's first two traffic private-toll bridges ${ }^{21}$.

In 1881, the HBC opened its first retail store in Winnipeg on the junctions of Main Street and York Avenue. This HBC Winnipeg store would quickly expand to include a powerhouse, garage, wholesale building, and executive offices. Following the advice of one of HBC's directors - whom was previously with Harrods department store in London, England - in 1912, The HBC would set about building their "Original Six" department stores in Victoria, Vancouver, Edmonton, Calgary,
Saskatoon, including Winnipeg. ${ }^{15}$

Outgrowing its retail store on Main Street, in 1925 the HBC set forth to build a seven-story flagship department store situated on the corner of Portage Avenue and Memorial Boulevard, strategically aligning itself with the Provincial Legislative Building a few blocks south. ${ }^{16}$

Over the following years, the HBC would become a major player in the continuous development of Memorial Boulevard in Winnipeg, Manitoba. $\infty$ 
Endnote.

01. Auld, Abigail. WPGxHBC Website. About. Accessed Sept. 10, 2014. www.wpgxhbc.com/

1a. Ray, Arthur J., Jim Miller, And Frank Tough. Bounty and Benevolence: A History of Saskatchewan Treaties. Montreal, QC: Mc Gill-Queen University Press. 2000.

02. HBC Heritage. Website. Our History: Overview. Accessed Oct. 18, 2014. www.hbcheritage.ca/hbcheritage/history/

03. PBS. Website. Empire of the Bay: Introduction - Retrace the Steps of the Hudson's Bay Company's History.

Accessed Oct. 13, 2014. www.pbs.org/empireofthebay/ timeline/intro.html

04. Dafoe, Christopher. Winnipeg: Heart of the Continent.

Winnipeg, MB: Great Plains Publications, Ltd. 1998. pg. 16.

05. Dafoe, Christopher. Winnipeg: Heart of the Continent.

Winnipeg, MB: Great Plains Publications, Ltd. 1998. pg. 21.

06. Ibid. p. 30-31

07. Ibid. p. 34

08. Ibid. p. 35.

09. Shilliday, Gregg. A History of Manitoba: Volume One -

Rupert's Land to Riel. Winnipeg, MB: Great Plains Publications,

Ltd. 1993. p. 169.

10. Shilliday, Gregg. A History of Manitoba: Volume One -

Rupert's Land to Riel. Winnipeg, MB: Great Plains Publications,

Ltd. 1993. p. 170.

12. Ibid. p. 174

13. Ibid. p. 176

14. Newman, Peter C. Empire of the Bay: An Illustrated History of the Hudson's Bay Company. Toronto, ON: Madison Press Books. 1989. p. 180

15. HBC Heritage. Website. Accessed Dec. 18, 2014. www.

hbcheritage.ca/hbcheritage/history/overview

16. Auld, Abigail. WPGXHBC. Website. Accessed Dec. 19

2014. www.wpgxhbc.com/filter/commercial/commercial-

description

17. Newman, Peter C. Empire of the Bay: An Illustrated History of the Hudson's Bay Company. Toronto, ON: Madison Press Books. 1989. p.201

18. Auld, Abigail. WPGxHBC Website. Land Development

Accessed Dec. 21, 2014. http.//wpgxhbc.com/filter/land/A-2-1

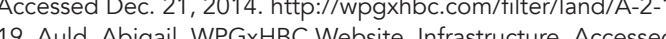
ure. Accessed Dec. 22, 2014. http://wpgxhbc.com/filter/infrastructure/

frastructure-description

20. Auld, Abigail. WPGxHBC Website. Infrastructure. Accessed

Dec. 28, 2014. http://wpgxhbc.com/filter/infrastructure/B-1-4
21. Auld, Abigail. WPGxHBC Website. Infrastructure. Accessed Dec. 28, 2014. http://wpgxhbc.com/filter/infrastructure/B-1-1 



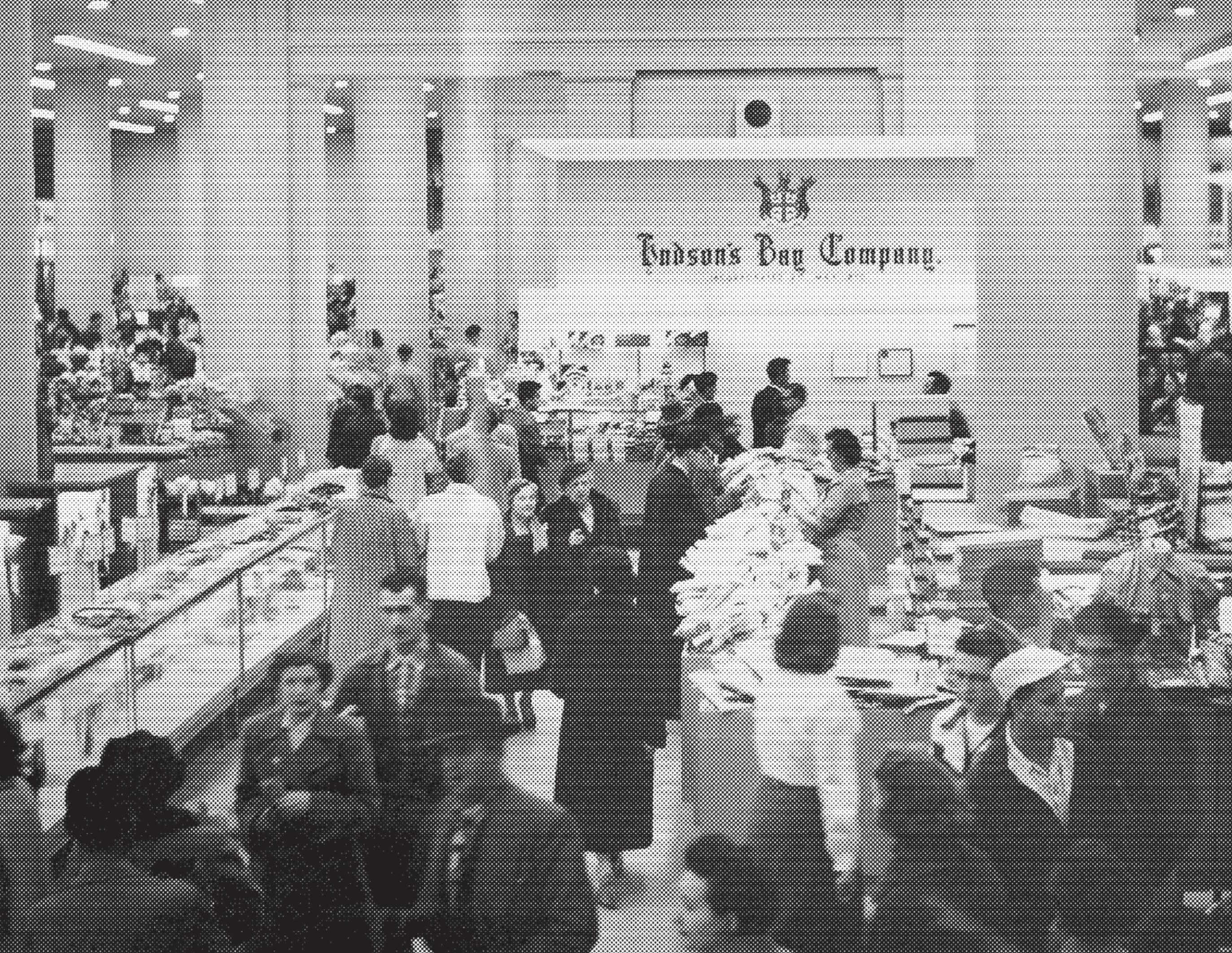


CHAPTER 5

The Hudson's Bay Company: The Department Store

fig. 37. (previous page) The HBC's Department Store. Main Retail Floor, 1950. Winnipeg, MB. Photograph. HBC Archives Collection. HBCA 1987/363-W-316/108

"Opening Day. The Hudson Bay store opened in Winnipeg on November 18, 1926. People lined up for blocks around; one of the plate glass windows was broken and carloads of police were on hand to maintain decorum. Fifty thousand Winnipeggers went through the store that first day."

As noted in earlier chapters, The HBC's presence on Manitoba's soils was long established decades before the actual presence of its retail operations itself. It was in 1881, just over two centuries since the company's incorporation, that The HBC would makes its retail presence in Winnipeg opening its first sales shop on Main Street and York Avenue - this store was only its third store ever, following suit after the construction of their sales shop in Fort
Langley, BC (1857) and Fort Victoria (1859) ${ }^{2}$. The HBC Winnipeg saleshop would expand to later include a powerhouse, garage, wholesale building, and executive offices. HBC inspector Thomas R. Smith would go on to describe the shop by saying "The style of architecture is possibly without a name, except that of 'Warehouse', and can scarcely lay claim to any degree of beauty, the general effect conveyed being rather that of solidity." 3 
The HBC's earlier stores and other infrastructure developments during this time lacked consistency throughout their architecture, and would not appear to do so until some decades later with the introduction of its first department stores in both Kamloops, BC in 1911, and Calgary, $A B$ in $1913^{2}$. Back in Winnipeg, The HBC was quickly outgrowing its 1881 store, and with its two other department stores well under construction, it was evident, Winnipeg was next in line for a grand retail expansion.

In 1925, The HBC would set forth to build a seven-story grand department store situated on the corner of Portage Avenue and Memorial Boulevard, strategically aligning itself with the Provincial Legislative Building a few blocks down. Completing its construction six years after the Manitoba Legislative Building was built in 1920, The HBC had decided to strategically place itself along Portage Avenue a decade prior in 1910, but was still awaiting the completion of the Legislative Building and the final plans for Memorial Boulevard4. Memorial Boulevard was part of the city's Mall of Triumph grand master plan (see figure on following page) during the very early 20th century, when the government of Manitoba announced to all architects of the Dominion of Canada a competition to design its new legislative building; with "First prize: $\$ 10,000 .{ }^{15}$

Although Winnipeg's Planning Commission was still new and inexperienced, they were right to assume that "a more aesthetically pleasing and welcoming community creates better people" 5 , resulting in Winnipeg's philosophy of City Beautiful, where a vibrant and attractive community would foster healthy and vibrant citizens. This notion was extended from small parks and gardens, to majestic monument plans for the city, similar to Washington's National Mall. The Mall 


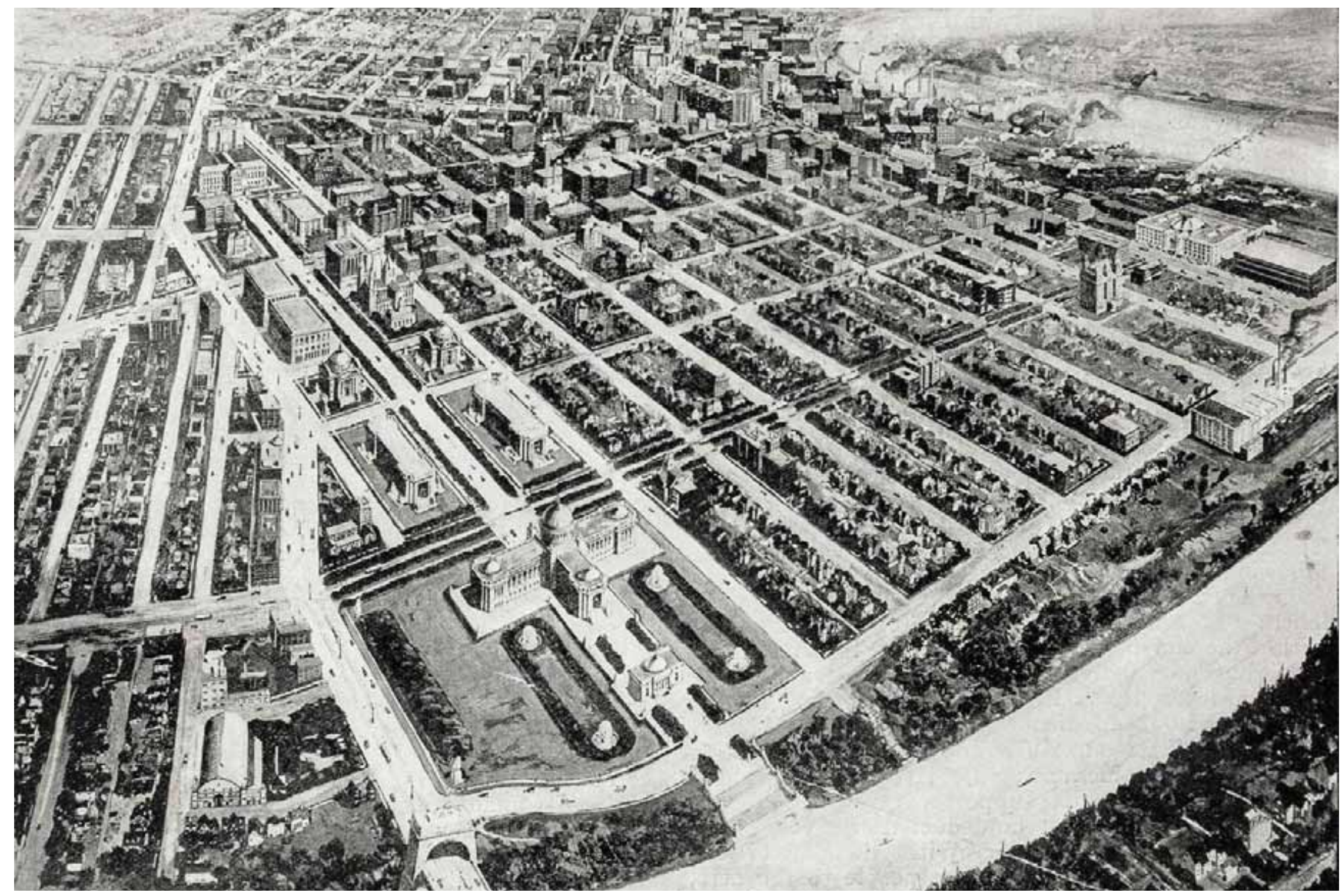


of Triumph was Winnipeg's translation of Washington's National Mall, an architectural master plan that included landscape, greenery, monuments and memorials. The monumental scheme would stretch some $600+$ meters north of the Provincial Legislative building to Portage Avenue, and to where a proposed city hall would have been built - today Memorial Boulevard takes its place, and is also where The HBC's department store is established. The city even established a subcommittee that was to help architect J.D. Atchison realize the city's dream of a grand boulevard, demonstrating Winnipeg as a city of importance during this time. ${ }^{5}$

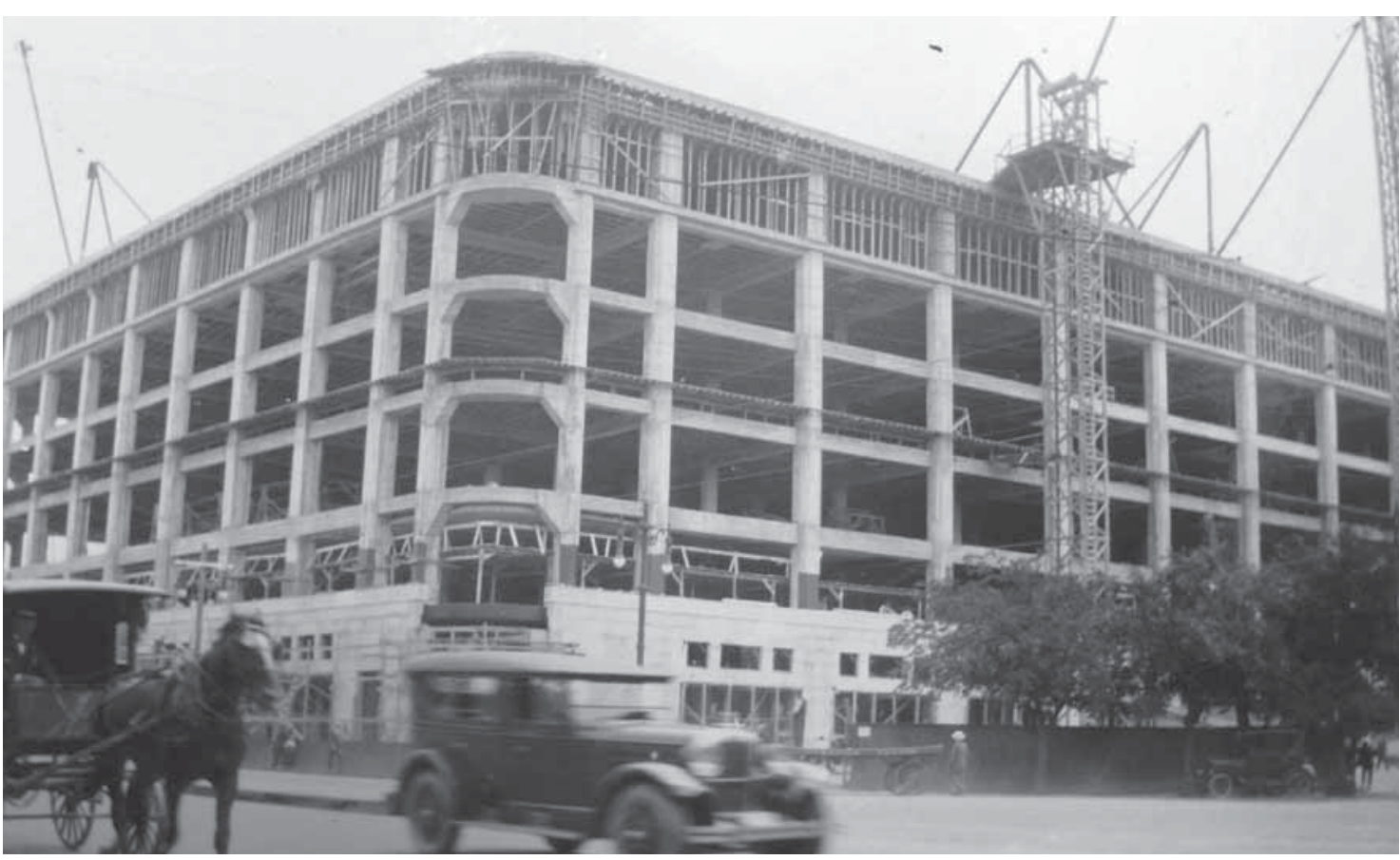

fig. 38 (previous page). The Mall of Triumph grand master plan. Drawing. Unknown. Image retrived from http://www. winnipegfreepress.com/city-beautiful/City-Beautiful---Part-1-Great-Expectations-273837201.html?cx_navSource=dspotlight

fig. 39 (above). The HBC's Department Store Under construction. 1925-26. Portage Ave \& Colony St. Winnipeg, MB Photograph. HBC Archives Collection. HBCA 1987/363-W-315/36

Construction of the upscale department store would involve the removal on some 150000 tons of earth, this would involve over
300 men, 120 teams of horses, 20 trucks, and 2 steam shovels. When completed, the building was the largest reinforced concrete building 


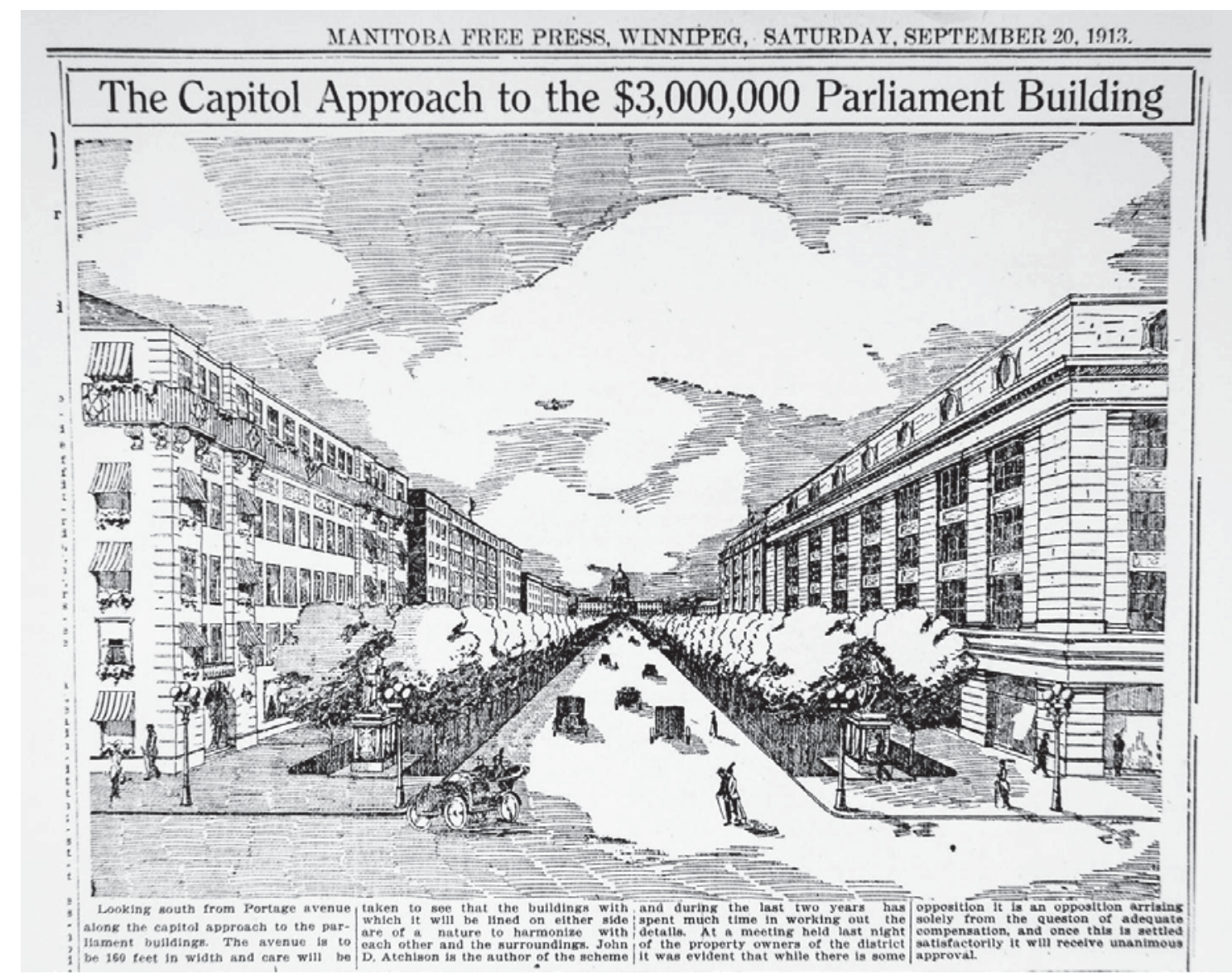

fig. 40. The Capitol Approach to the $\$ 3,000,000$ Parliament Building. Manitoba Free Press. Winnipeg, MB. Sep. 30, 1913. Image retrived from http://www.winnipegfreepress.com/city-beautiful/City-Beautiful---Part-1-GreatExpectations-273837201.html?cx_navSource $=$ d-spotlight

\section{THE CAPITAL APPROACH}

TO THE \$3,OOO,OOO PARLIAMENT BUILDING. Looking south from Portage avenue along the capital approach to the parliament buildings. The avenue is to be 160 feet in width and care will be taken to see that the buildings with which it will be lined on either side are of a nature to harmonize with each other and the surroundings. - John D. Atchison"- Manitoba Free Press, Winnipeg. Saturday September 20, 1913." 5 - Rand Turner. Winnipeg Free Press. City Beautiful: How Architecture Shaped Winnipeg's DNA. Part 1: Great Expectations. 
in Canada, comprising of 100000 tons of concrete, 120000 cubic $\mathrm{ft}$ of Tyndall Stone, and 2 million feet of lumber. The store officially opened its doors on November 18, 1926, with only three of its seven floors complete at that time; the remaining four floors would be completed the following year in August of 1927. Staffing nearly 2,000 employees, the department store's amenities included a post-office, library, beauty parlour, public telephones, and later an auditorium was added, complete with its own orchestra ${ }^{6}$.

The store originally had twelve elevators; six were since removed to make room for escalators. Originally

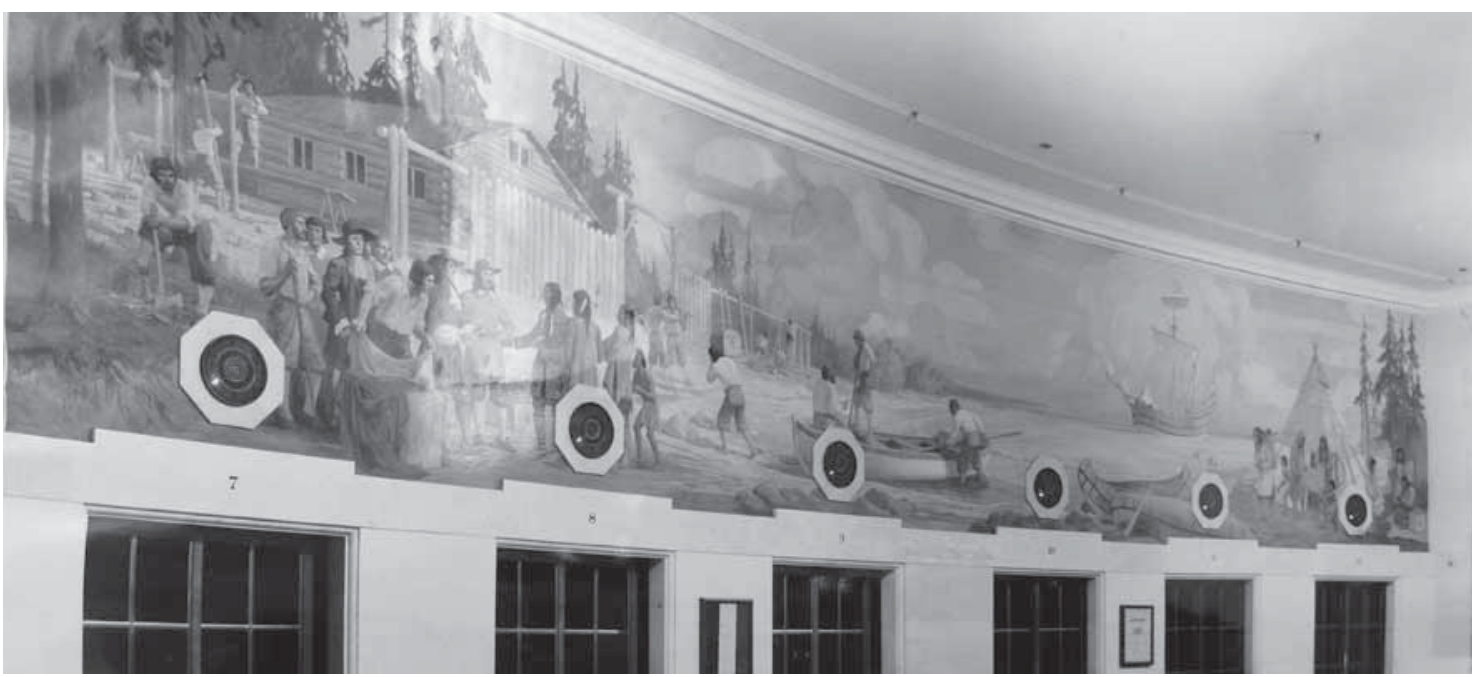

fig. 41. The HBC's Department Store enourmous elevator mural by A.Sherriff Scott and E.T. Adney. Winnipeg, MB. Photograph. HBC Archives Collection. HBCA 1987/363-W-316/20B

adorned with enormous murals which were painted by artists Adam Sheriff and Edward Tappan Adney - the elevators had even featured uniformed elevator operators, "usually women of approximately the same height, called out the department as they stopped at each floor." 8 With the introduction of the automobile, in 1954 The HBC decided to build a two-level parkade behind its store to accommodate those with vehicles $^{9}$ - later this parkade would eventually expand to four levels, and occupying the remainder of the city block. 


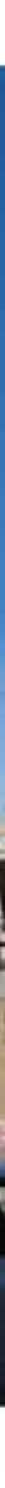


Probably most synonymous with The HBC are their Point Blankets (pictured right). The "point" system had been invented by French weavers in the mid 18th $\mathrm{c}$. as a means of indicating the finished overall size (area) of a blanket (7). Readily observed by their four bands of colour, these blankets were first typically referred to as the Chief's Blankets, and the standardization of its colour-bands was not done until 1860. The Green, representing land, Red for the hunt, Yellow for harvest, and Indigo for water, this colour scheme is the most popular and common, but can also come in other colours and/or patterns varieties. ${ }^{7}$

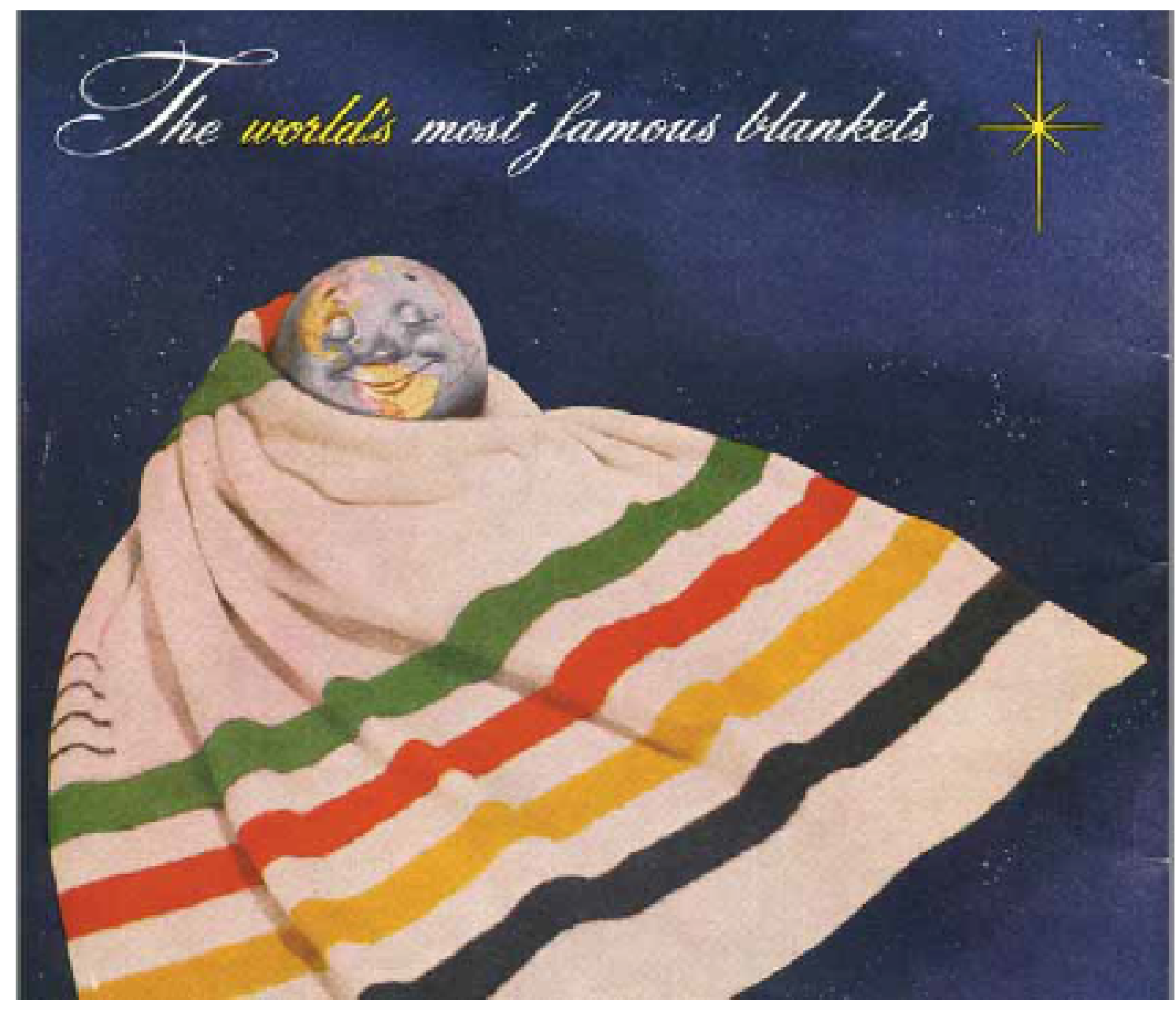

fig. 42. The Hudson's Boy Company's Point Blarket. Illustration. The Beaver magazine cover. Imaged rotrieved from http://www.patrimoinehbcca/hbcheritage/pictures/annonces-imprimees

fig. 43 \&. 44 (previous poges). The HBC's Department Store along Memorial Avenue. In figure 44, the Manitoba Legislative Building can be seen. Winnipeg, MB. Personal photo collection. 2014. 
Point Blankets are typically passed down from generation to generation, and became first popular as trade for beaver's pelts.

Today, The HBC's downtown department store is:

"looking worn and tired. In contrast to its shining and bustling counterpart just a few minutes' drive away at Polo Park, the downtown store gave the impression of having more space than customers, and was clearly in need of upgrading. Worn, scuffed tiles, duct-taped carpets, and curling parquet eroded by billions of footsteps were clear evidence of the busy department store it once was. The fact that the flooring hadn't been replaced told of the limbo in which the entire building found itself." 10

As Winnipeg is in the midst of an expansive architectural revival throughout the city, The HBC's Portage avenue department store patiently sits awaiting its fate, its next grand scheme. $\infty$ 


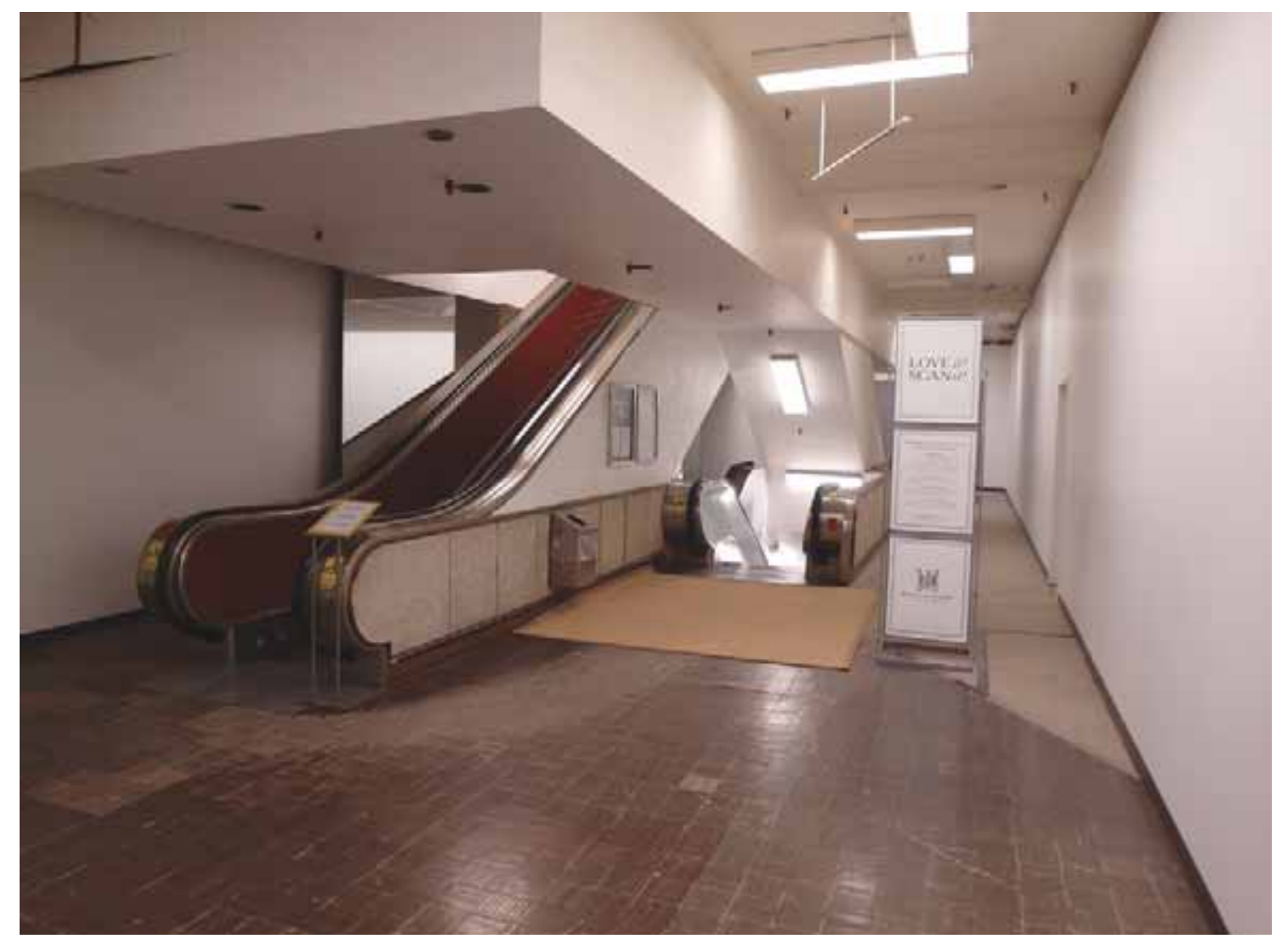

Worn, scuffed tiles, duct-taped carpets, and curling parquet eroded by billions of footsteps were clear evidence of the busy department store it once was. The fact that the flooring hadn't been replaced told of the limbo in which the entire building found itself." ${ }^{10}$
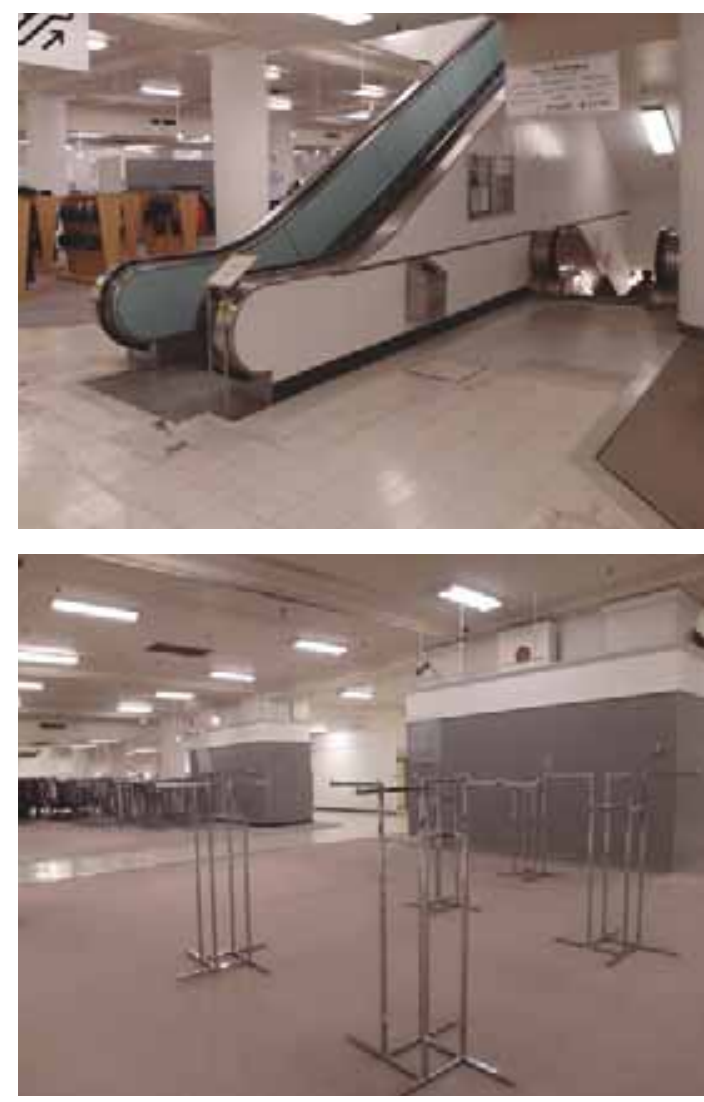

fig. 45, 46, \& 47. The current state of HBC's Department Store. Portions of the building have been closed off to public, in conjuction to the large open spaces that are indicative of both the building's physical and economical decline. Winnipeg, MB. Personal photo collection. 2014. 


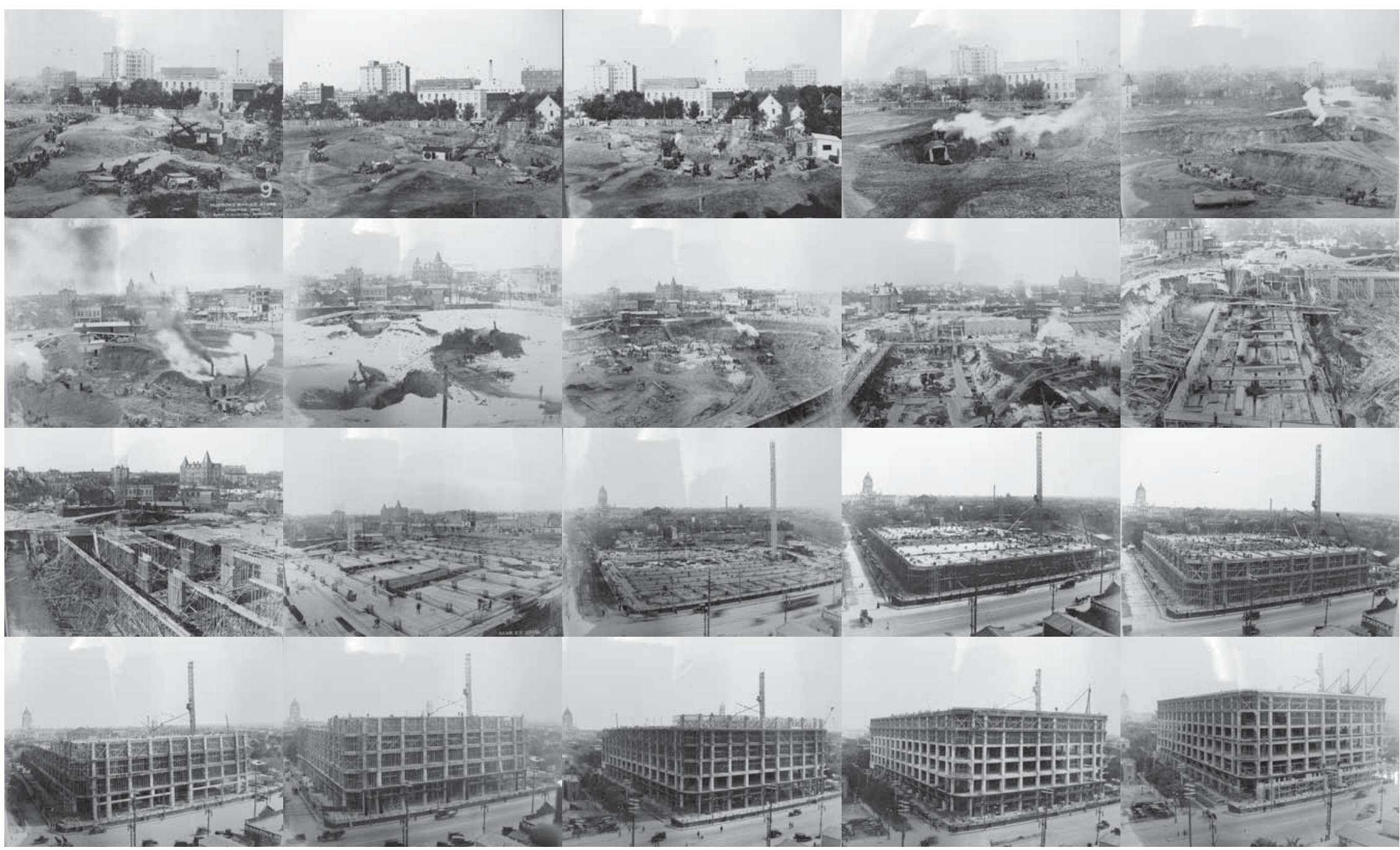




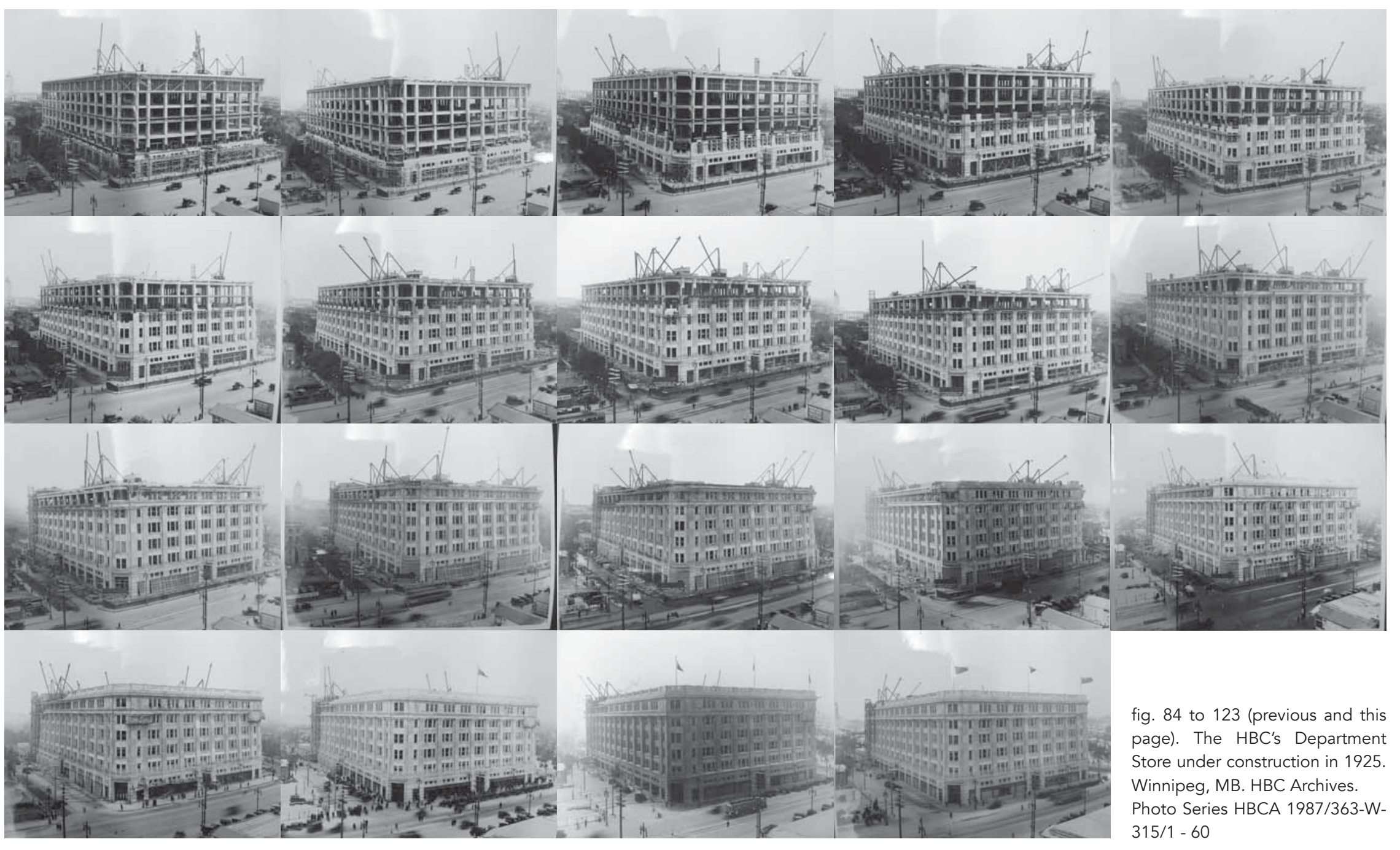


01. HBC Heritage. Website. Our History: Timelines: Early Stores. Accessed Mar. 02, 2015. http://www.hbcheritage.ca/ hbcheritage/history/timeline/early/home

02. Ibid.

03. Auld, Abigail. WPGxHBC Website. Commercial. Accessed Feb. 24, 2015. http://wpgxhbc.com/C-2-2-1

04. Gourluck, Russ. Going Downtown: A History of Winnipeg's Portage Avenue. Winnipeg, MB: Great Plains Publications. 2009. p.236

05. Turner, Randy. Winnipeg Free Press. Website. City Beautiful: How Architecture Shaped Winnipeg's DNA. Part

1: Great Expectations. Accessed Jan 11, 2015. http://www. winnipegfreepress.com/city-beautiful/City-Beautiful---Part-1 Great-Expectations-273837201.html.

06. Gourluck, Russ. Going Downtown: A History of Winnipeg's Portage Avenue. Winnipeg, MB: Great Plains Publications. 2009. p.236

07. HBC Heritage. Website. Our History: The Hudson's Bay Company Point Blanket: History. Accessed Mar. 02, 2015. http://www.hbcheritage.ca/hbcheritage/history/blanket/history/ 08. Gourluck, Russ. Going Downtown: A History of Winnipeg's Portage Avenue. Winnipeg, MB: Great Plains Publications. 2009. p.239

09. Ibid. p. 245.

10. Ibid. p. 249. 

The Architecture. Part Three

Winnipeg's Current Situation: the Good, the Bad... 109 and the Ugly: an Architectural Intervention 122

Project Portfolio: an Aboriginal Embassy 131 


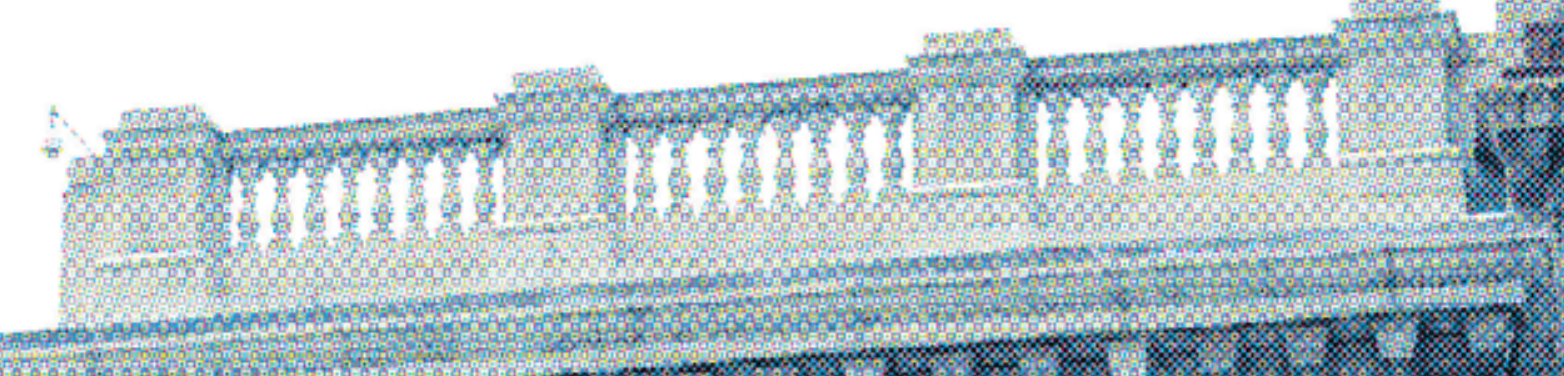
का .

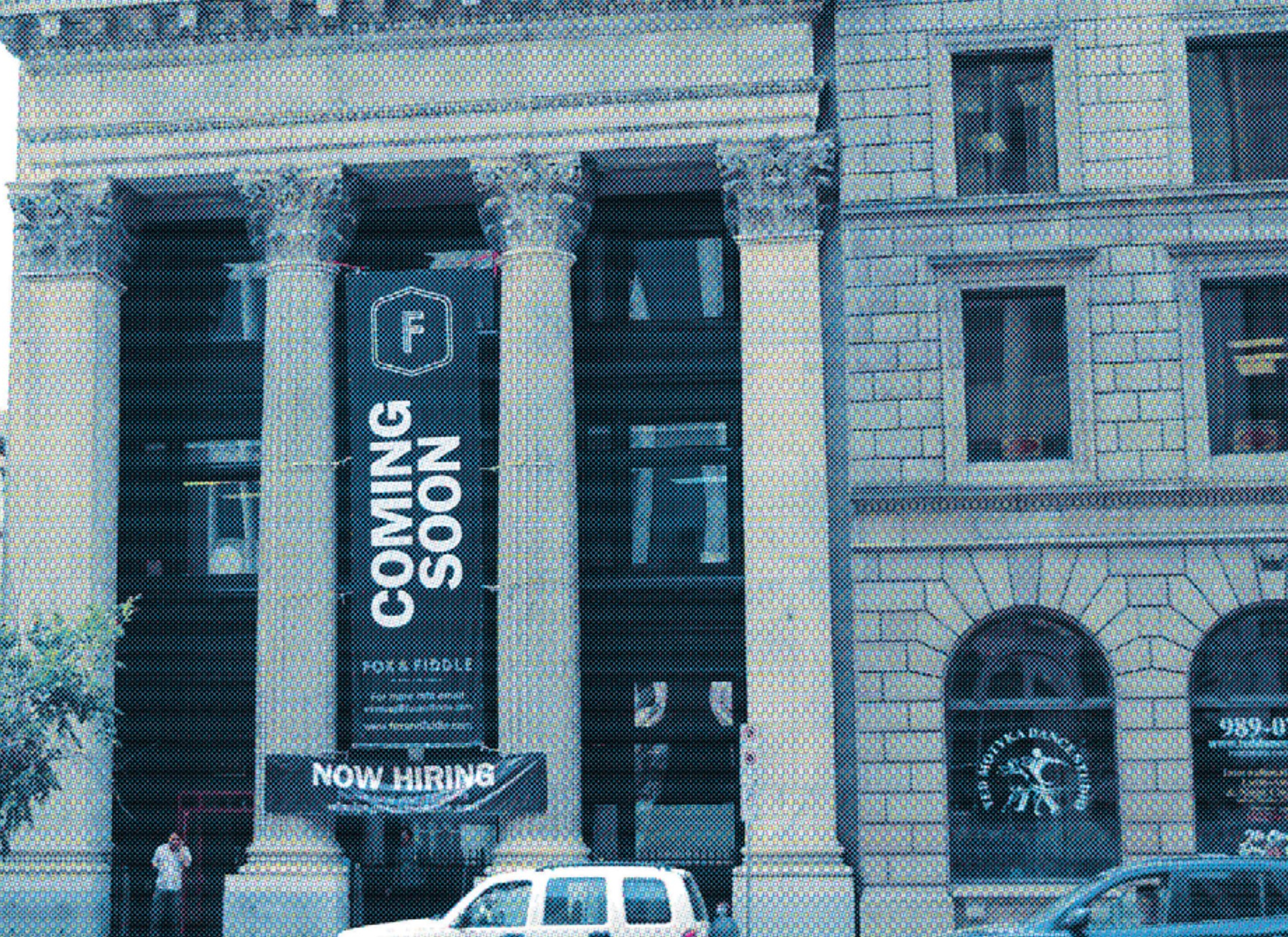

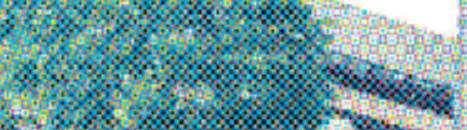

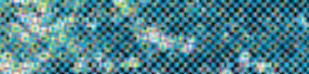

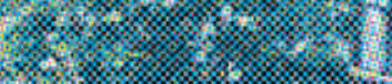

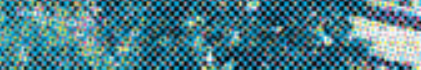

.

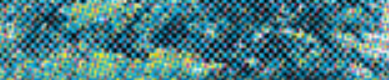

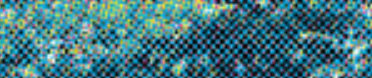

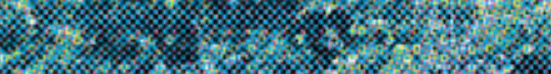

1.

: 1.

1.

: $4)^{2}=x$

\% 1200

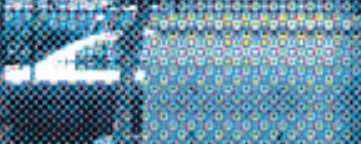

8

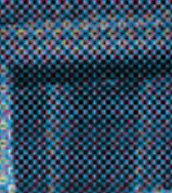

学

如 


$\begin{aligned} \text { CHAPTER } 6 & \text { "Manitoba } \text { emerged from the social and economical } \\ \text { Winnipeg's Current Situation: } & \text { brawls of the } 1980 \text { 's bruised but unbowed." } \\ \text { the Good, the Bad... } & \text {-Shilliday, Gregory. A History of Manitoba }\end{aligned}$

The city of Winnipeg's historic lineage spans nearly a century and a half, and along for the ride is its historic and enduring architecture. Throughout the beginning of the twentieth-century, Winnipeg's architecture scene was full of optimism, planning of the city Winnipeg's Golden Era ${ }^{25}$ - was on a grand scale, with renowned architects from across Canada and the United States being recruited to help realize

fig. 48. (previous page) Fox and Fiddle Pub takes up an old Toronto Dominion Bank building. Exchange District along Main Street. Winnipeg, MB. Photograph. Personal Collection. 2012. the city's true potential.

After some political and financial corruption, which nearly always seems to be the case, the city's architecture lay dormant up until its awakening during the 1950s and 60s with the arrival of the Modern architecture movement. Short lived; the city's design and planning faction stepped out of the spotlight again.

Now into the first decade of the new millennia, the city of Winnipeg is on an upward momentum. Again being redefined through its architecture, the city's need of maintaining a dialogue with 
its historic origins is imperative in the revitalization of its desperate and dilapidated urban core.

"... [L]ocate at the confluences of the Red River and Assiniboine"1 River, survives the isolate prairie city of Winnipeg, Manitoba. Roughly translating to muddy-water (Win-nipi) from Cree1, Winnipeg is the largest populated city within the province of Manitoba, with an estimate population of $664,000^{2}$ (Statistics Canada 2011 Census).

The city - specifically where the Assiniboine and Red rivers converge: site of The Forks - began as an important gathering site for Canada's Western Plains Aboriginal

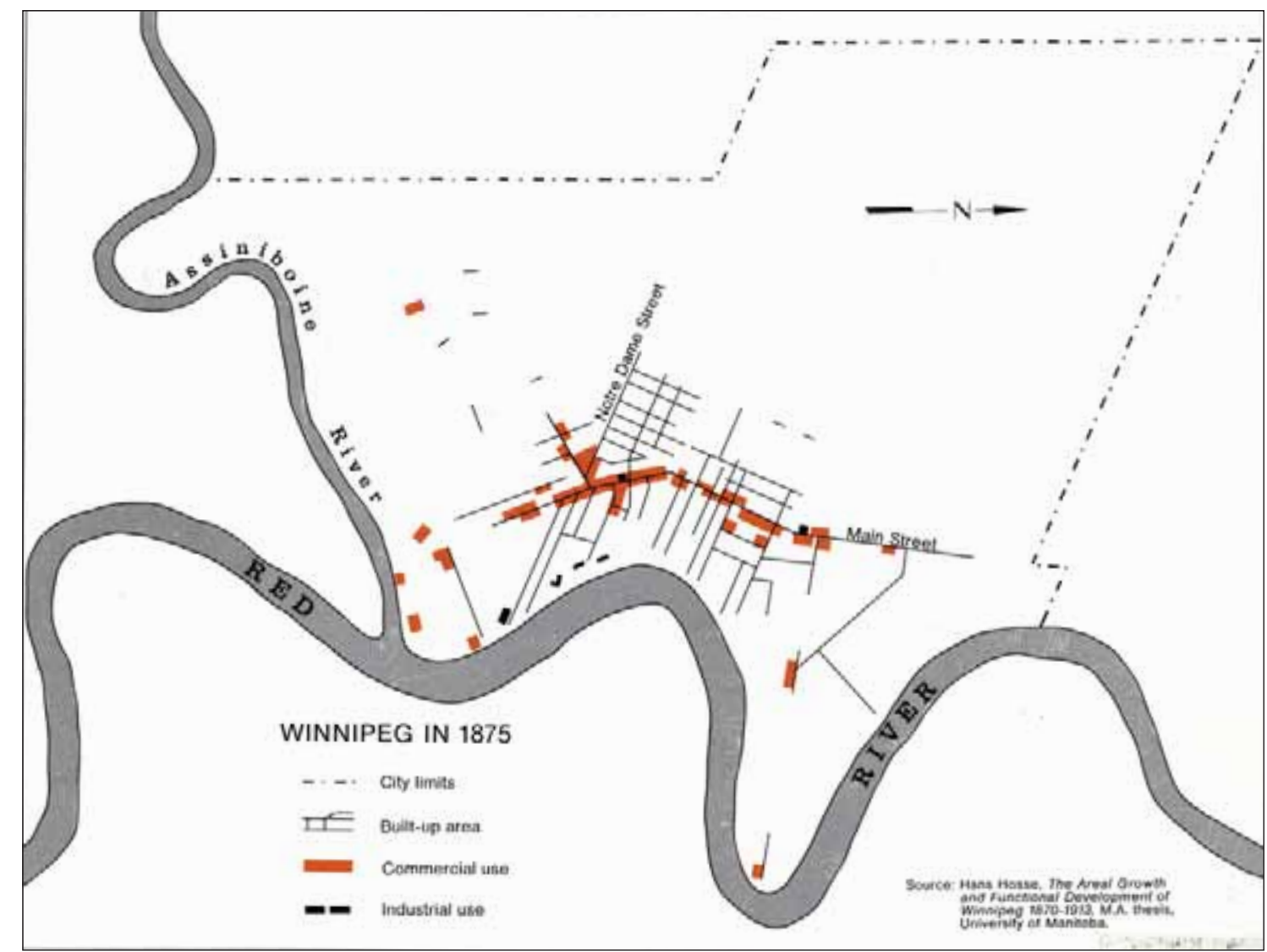

people. Long before the arrival of 17th century European pioneers fig. 49. 1875 Map of Winnipeg, two years after the city was Incorporated. Thomas. R Weir. 1912. Print. Atlas of Winnipeg. Toronto, ON: University of Toronto Press. 1978.

and settlers, the site was used as a significant transportation route and 
assembly point for Aboriginal people along both its rivers and banks. Aboriginal bison hunting groups have been traced as far back as 6,000 years ago, with Algonquianspeaking groups being the first to have seasonally-inhabited the site. ${ }^{3}$

As early as the late 18th and early 19th centuries, the site of The Forks has since become an important junction point for both Aboriginals and Europeans; with Europeans first arriving by canoe around 1738. With the establishment of Winnipeg's first fort, Fort Rouge by *La Vérendrye, along with many other forts and trading posts erected in the region at that time, their location(s) were equally important and strategically planned due to their relative close proximity to The Forks - for reasons of being easily accessible to a significant transportation route. In addition to being able to access this river network for transport, the site of The Forks offered its inhabitants an abundance of resources including food resources, fish, and wild game, most notably the bison. ${ }^{3}$

Permanent settlement around and adjacent to The Forks occurred roughly around 1812, with Scottish crofters being the first Europeans. The Hudson's Bay Company (HBC) would establish its first fort, Fort Garry in 1870 - two hundred years
As The Forks had great strategic importance economically, it was the aim of these first fur traders and the subsequent waves of settlers to control the activities of these economic lifeline." ${ }_{5}$

- Christopher Dafoe. Winnipeg: Heart of the Continent. 
after the company's incorporation with a mere population of 215 at that time. In 1873, the population would grow to 1,869 inhabitants, the same year the city became incorporated. Five years later in 1878 , the steam railway network would make contact with the American city of St. Paul, Minnesota, when rail tracks would connect the two cities 730 kilometers apart from one another. ${ }^{4}$ Benefiting from this city's geographical location - situated approximately at midpoint between both Pacific and Atlantic oceans - the city of Winnipeg would see the rise and prosperity of its railway transportation system, along with its significant population growth.

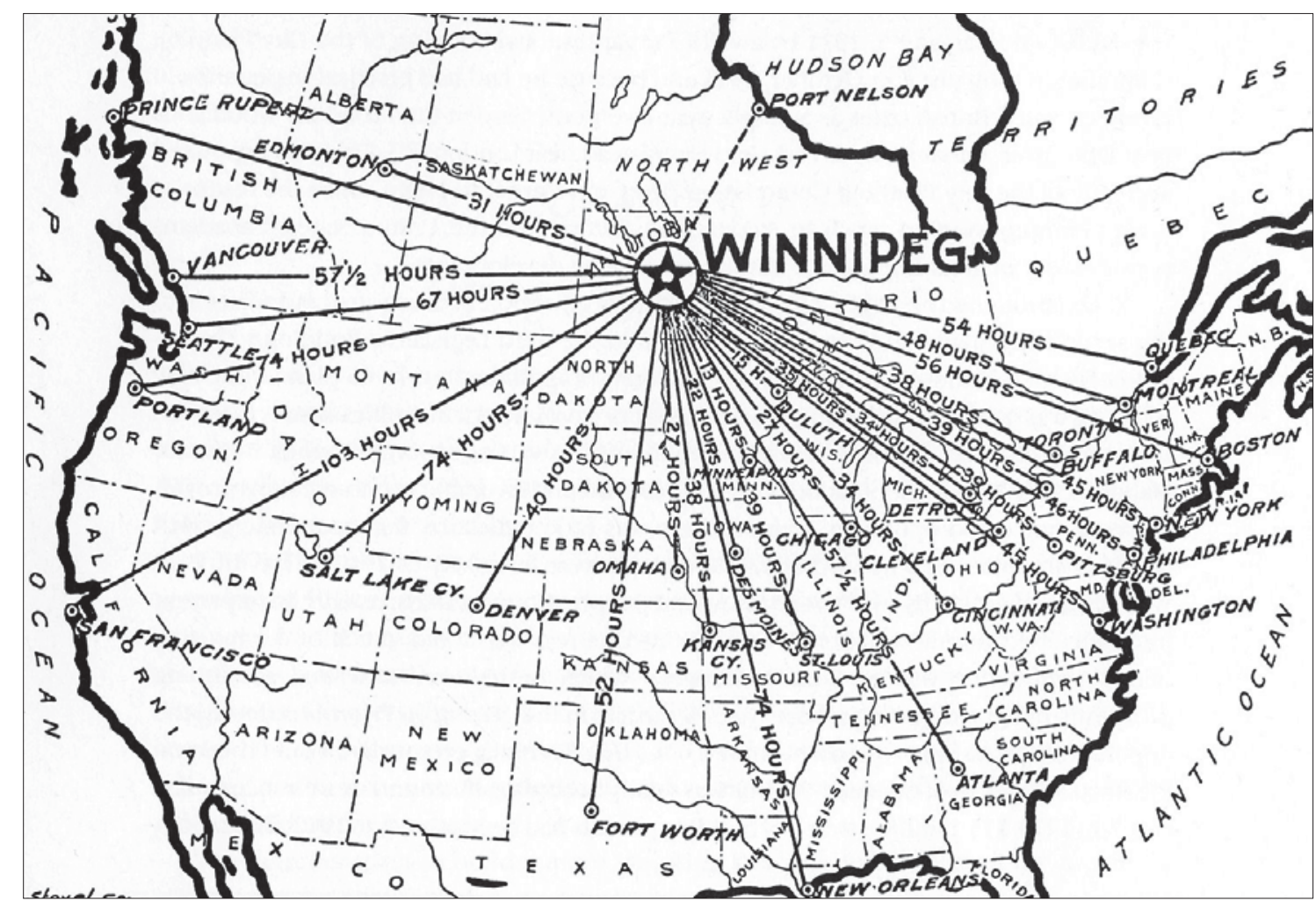

"The advent of the railway connections introduced a steady stream of travel and trade and an influx of population that resulted in the building up of a

fig. 50. Map depicting Winnipeg as 'Center of North America'. Thomas. R Weir. Print. Atlas of Winnipeg. Toronto, ON: University of Toronto Press. 1978.

is exceeded by only a few cities in Canada." ${ }^{4}$

City of standing and importance that 
In 1885, the city would see the arrival of the Canadian Pacific Railway systems, which would allow the city to continuously develop and grow steadily for some 30 years, "unequalled in Canadian urban development."4 Immigration, profitable wheat prices, a steady flow of capital, and advancements in farming techniques would allow for Winnipeg to become the financial hub of Western Canada during this time.

Between 1945 and 1972, the city would continue its steady growth, most notably due to its significant influences on the grain, financial, manufacturing, and transportation

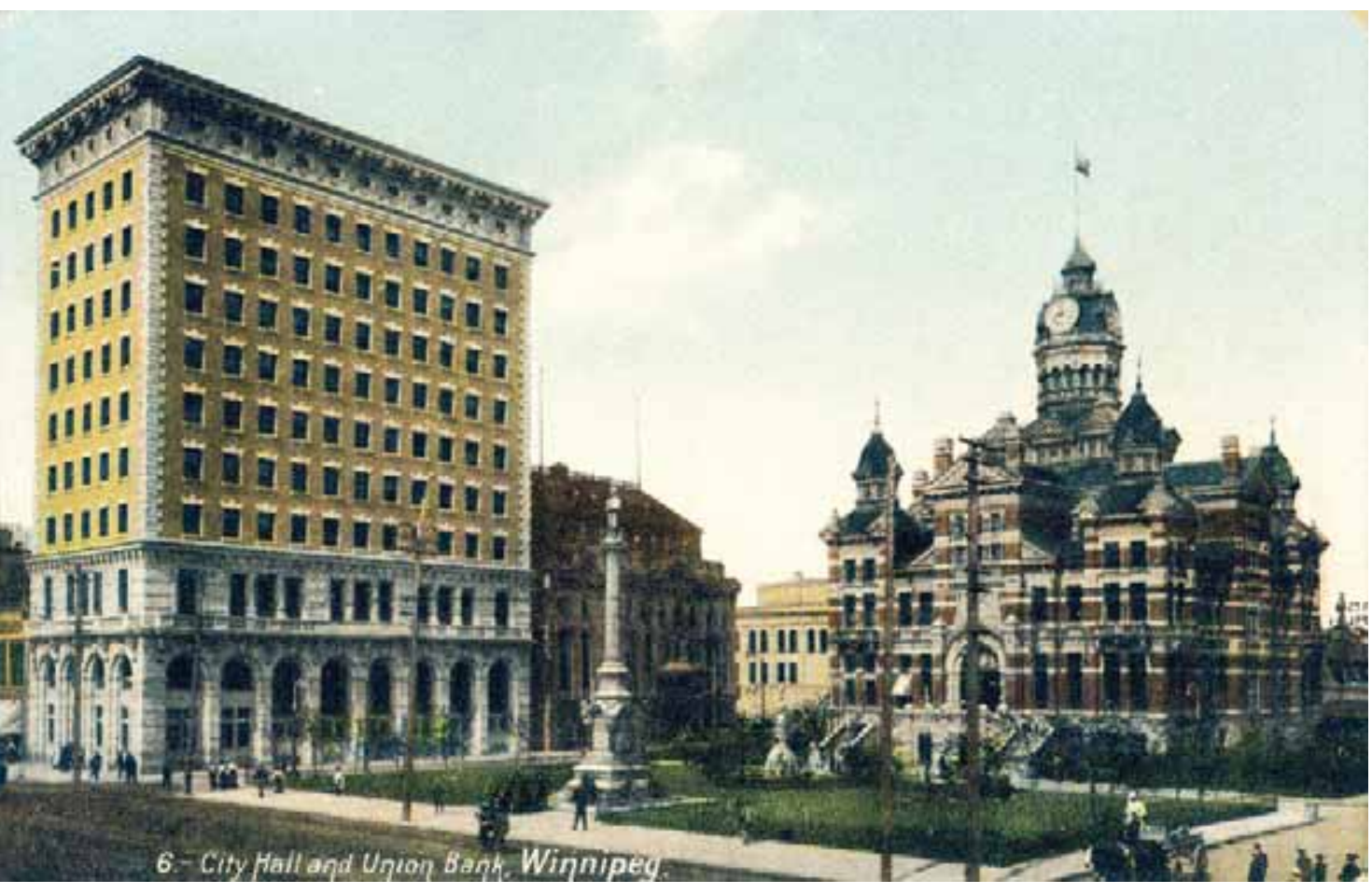

fig. 51. City Hall and Union Bank, with Leland Hotel. Winnipeg, MB. Postcard. of Winnipeg (Consolidated Stationery Company (C.S.Co) in Winnipeg. 1907.

industries across Canada. In 1972,

Winnipeg would become the amalgamation of thirteen surrounding municipalities, towns and cities. ${ }^{4}$

Winnipeg was, and still is very much characterized by its railway lines that run abundantly throughout the entire city, where it notably divided the city into virtually two distinct precincts: the "North End", and the 
rest of the city. The North End was primarily populated with the city's Slavs and Jewish communities, while the south and west saw a strong "prosperous and politically dominant Anglo-Saxons"7 community and influences.

Early 20th century architecture of Winnipeg was vernacular to its region, and nicknamed "Red River Frame"7 consisting of horizontal and vertical log style dwellings. Public buildings, and houses of the wealthy were built using limestone, which is locally sourced from nearby quarries. In 1886, downtown Winnipeg would be adorned with stylistic buildings such as the picturesque Victorian style city hall, which was nicknamed the "Gingerbread"7 for its exceptional use of ornamentation. This Victorian style of architecture would eventually translate to the vernacular housing of its many surrounding downtown boroughs. The city's commercial and financial districts would begin to establish itself around Portage Avenue, and Main Street with the construction of many notable financial institutions - all of which are located at the city's center, in very close proximity to The Forks site.

The majority of downtown Winnipeg's change would come during the late 1980s with the extensive development of Portage
Avenue which would include "new office and apartment buildings, major shopping mall, enclosed pedestrian bridges..." and " one of the most historically intact turn-of-the-century warehouse areas in North America": the Exchange District. ${ }^{7}$ 


\section{Winnipeg Today}

Early twenty-first century Winnipeg is in many ways like early twentieth century Winnipeg - or at least most of its architectural buildings downtown are. Downtown Winnipeg of today is defined by its diverse juxtaposition of old and new architecture.

Winnipeg's Exchange District - as of 1997 a National Historic Site contains twenty-city-blocks of some of the most impressive and well intact early 20th century "Chicago Style" office buildings and warehouses; a total of 150 buildings $^{15}$ are under heritage protection, and that list continues to grow each year with

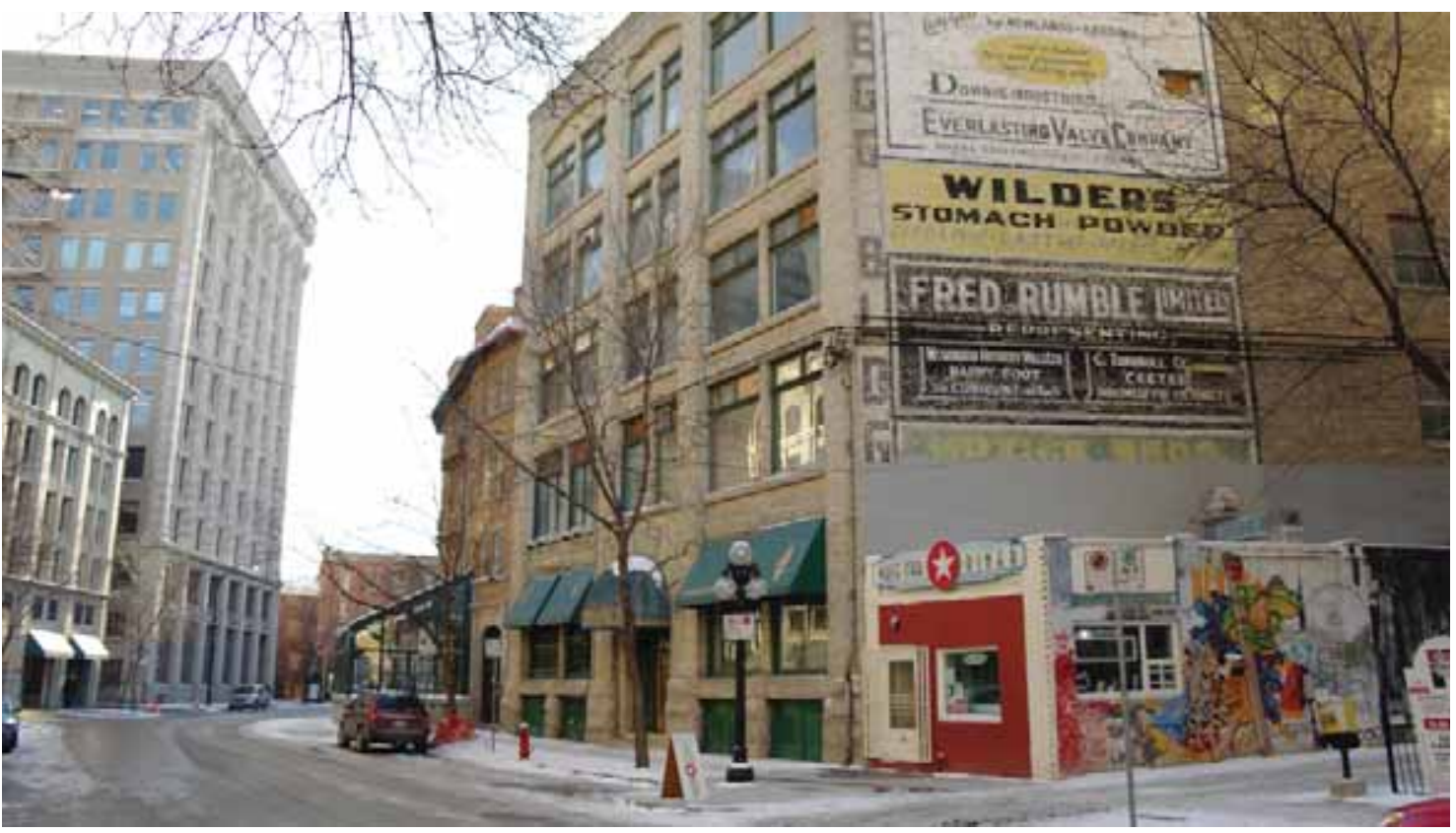

an interest to preserve Winnipeg's

fig. 52. White Star Diner on Albert Street. The Exchange District. Winnipeg, MB. Personal photo collection. 2011

heritage cityscape.

During the late 1980s and early 1990s, Winnipeg's downtown community began to drastically decline. High crime rates "prompted many Winnipegers to relocate out of

\section{$\int$ The Exchange District and Chinatown - containing some of the oldest commercial buildings - along with areas in the downtown core present an impressive panorama of Winnipeg's architectural history." 14}


the city's core" 20 to its many sprawling suburban areas. Winnipeg newly elected mayor, Susan Thompson (the city's first female mayor) ${ }^{21}$, was now faced with the overwhelming task: how to address Winnipeg's inner-street crime. And to complicate the matter even more, Winnipeg's suburban communities also offered its residents a lower property tax rate, making it even more attractive to leave Winnipeg's downtown community. Several revitalization attempts were put forth, with mix results. The site of The Forks however saw an overwhelming reception of tourism and locals, meanwhile one of the city's busiest commercial streets, Portage Avenue, continued its slump, "with shutdown businesses becoming all too common along the city's most famous artery." 22

Today, Winnipeg has seen some improvement, but at an exceptionally slow rate. In 2011, the city of Winnipeg introduced ** Our Winnipeg: It's Our City, It's Our Plan, It's Our Time. The strategy booklet is the city's 25-year vision and development plan on how the city can position itself for both continued and sustainable growth. ${ }^{23}$ The development plan covers more than just the city's basic requirements - public safety, water quality, wastewater and transportation infrastructure, and public amenities - but aims to address a variety of issues related to "various lifestyles, providing a range of options for living, working and playing... The whole system has to work together efficiently and sustainably."23 Our Winnipeg is divided into three distinct strategies: Complete Communities, Sustainable Transportation, and Sustainable Water and Waste.

As of 2004, Winnipeg has seen some its largest pieces of architecture to adorn its downtown cityscape: MTS Centre - a 440,000 square foot enclosed ice arena and entertainment complex, completed in 2004 16; Manitoba Hydro Building 
- a 115 meter state-of-the-art energy efficient head office tower, completed in $2009{ }^{17}$; OMS Stage - 28 foot x 28 foot $\times 28$ foot public performance stage located in the Exchange district, completed 2013 18; and the recently opened Canadian Museum for Human Rights - a 260,000 square foot national museum, the first one of its kind built outside of the nation's capital, completed in September 2014. These select pieces of architecture represent the many that stand to be the new face of Winnipeg's modern downtown cityscape, but should also never to forget to maintain its ongoing dialogue with its historic heritage

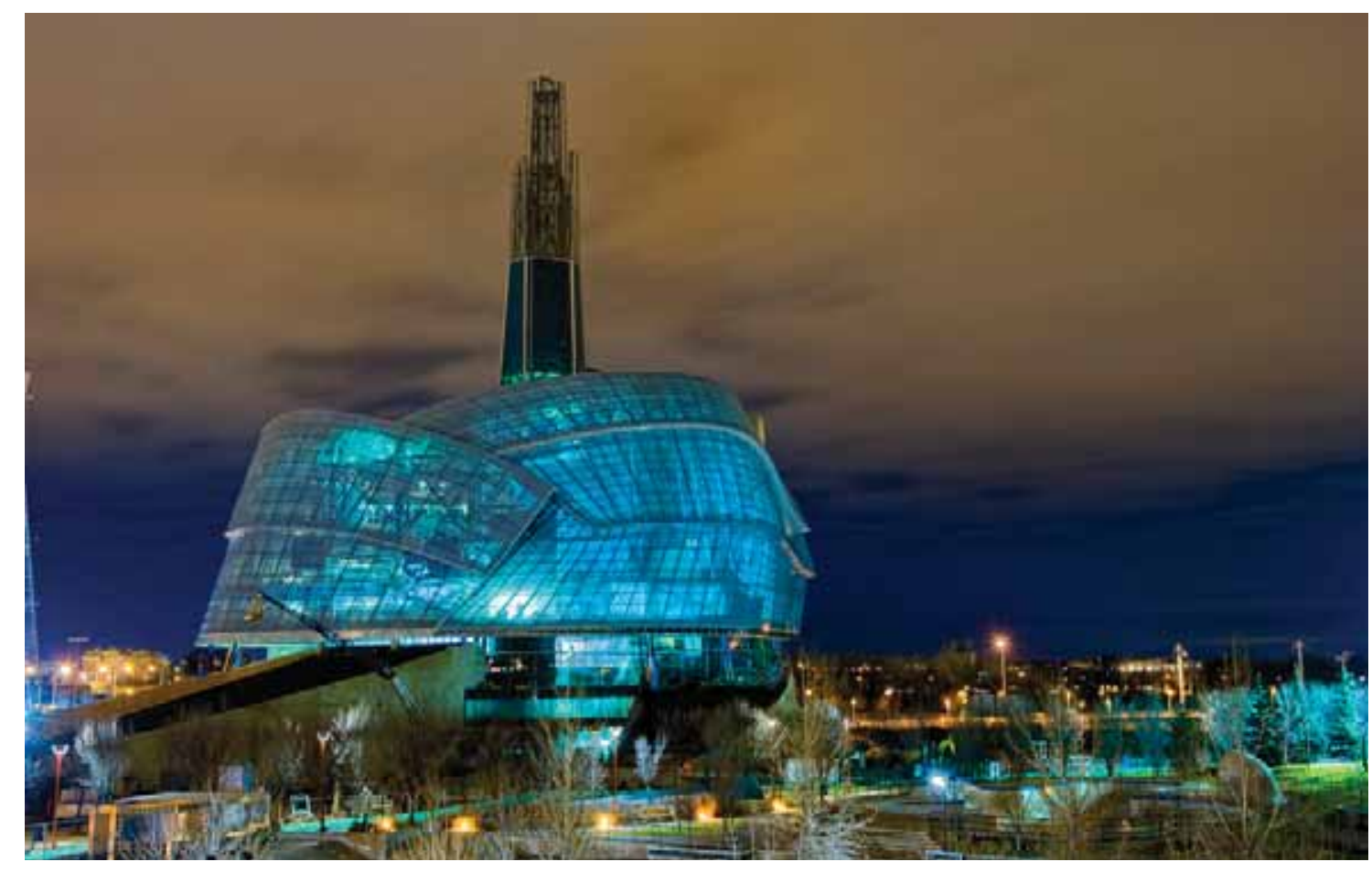

fig. 53. Canadian National Human Rights Museum. The Forks, Winnipeg, MB Photograph. Josel Catindoy. 2014. http://www.acec.ca/events_awards/acec_summit_and_national_convention/2013/summit2014.html

roots.

Now into the first decade of the new millennia, Winnipeg is again redefined, yet still maintaining its historic origins. "No longer the
'Gateway to the West', no longer the 'Breadbasket of the Empire', no longer a bastion of British, Protestant values, the new Manitoba [especially Winnipeg] was economically and 
culturally diverse." 24 Just like the confluences of its two muddy rivers, Winnipeg was born out of the convergence of two potent influences - the Hudson's Bay Company and the Aboriginal people. But it is Winnipeg's diversity - whether it be socially, economically, religiously, and especially culturally - that has proven to be Winnipeg's evolutionary trait allowing for its continued growth and success. $\infty$ 
* La Vérendrye: "In 1738, Sieur Louis Damours de Louvieres built Fort Rouge on the Assiniboine River for Pierre Gaultier de Varennes, sieur de La Vérendrye. La Vérendrye and his sons, Louis-Joseph and François, proceeded further west on the Assiniboine and constructed Fort La Reine. The fort seems to have had a primary purpose as a depot and was abandoned by 1749." Wikipedia. Website. Fort Rouge (fortification). Accessed Jan 2, 2015. http://en.wikipedia.org/wiki/Fort_ Rouge_\%28fortification\%29

\section{** Our Winnipeg: Complete} Communities will provide some of the guidelines and framework on topics and issues of concern when implementing the architectural design strategy to The HBC department store.

\section{Endnote.}

01. Artibise, Alan F.J. Historica Canada. Website. Cities and Populated Places: Winnipeg. Accessed Dec 18, 2014. http:// www.thecanadianencyclopedia.ca/en/article/winnipeg/ 02. Statistics Canada 2012. Winnipeg Manitoba (Code Census. Statistics Canada 8-316-XWE. Ottawa. Released October 24, 2012. Accessed December 10, 2014. http://www12.statcan.gc.ca/censusrecensement/2011/dp-pd/prof/index.cfm?Lang $=E$

3. The Forks. Website. The Forks 6000 Years Ago. Accessed Dec. 18, 2014. http://www.theforks.com/about/history

4. The City of Winnipeg. Website. http://www.winnipeg.ca/ services/CityLife/HistoryOfWinnipeg/HistoricalProfile.stm

05. Dafoe, Christorpher. Winnipeg: Heart of the Continent Winnipeg, MB: Great Plains Publication. 1998. p.11.

06. Dafoe, Christorpher. Winnipeg: Heart of the Continent. Winnipeg, MB: Great Plains Publication. 1998. p.10.

07. Artibise, Alan F.J. Historica Canada. Website. Cities and Populated Places: Winnipeg - Cityscape. Accessed Dec 21 $2014 . \quad$ http://www.thecanadianencyclopedia.ca/en/article/ winnipeg/

08. Natural Resources Canada. Website. Geological Survey of Canada: The Red River. Accessed Dec. 21, 2014. http://web. archive org/web/20110604201210/http://gsc.nrcan.gc.ca/ floods/redriver/geomorphology_e.php

09. Current Results. Website. Weather Extremes: Canada. Accessed Dec 24, 2014. http://www.currentresults.com/ Weather-Extremes/Canada/sunniest-cities.php

10. The City of Winnipeg. Website. Timeline of Winnipeg Historical Events 1670 - 2012. Accessed Dec. 21, 2014 http://www.winnipeg.ca/services/CityLife/HistoryOfWinnipeg/ HistoricalDates.stm

11. The Forks. Website. The Forks and Immigration 1870-1920 Accessed Dec. 22, 2014. http://www.theforks.com/about/ history

12. Artibise, Alan F.J. Historica Canada. Website. Cities and Populated Places: Winnipeg - Population. Accessed Dec 18 2014. http://www.thecanadianencyclopedia.ca/en/article/ winnipeg/

13. Statistics Canada. 2012. Winnipeg, Manitoba (Code 4611040) and Division No. 11, Manitoba (Code 4611) (table). Census Profile. 2011 Census. Statistics Canada Catalogue no. 98-316XWE. Ottawa. Released October 24, 2012. Accessed December XWE. Ottawa. Released October 24, 2012. Accessed December
20, 2014.https://www12.statcan.gc.ca/nhs-enm/2011/dp-pd/ prof/details/page.cfm? Lang $=E \& G e o 1=C S D \& C o d e 1=4611040$ $\&$ Data $=$ Count $\&$ SearchText=winnipeg \&Search Type
Begins\&SearchPR=01\&A1=Al|\&B1=All\&Custom $=$ \&TABID $=1$

14. Dafoe, Christorpher. Winnipeg: Heart of the Continent. Winnipeg, MB: Great Plains Publication. 1998. p.171.

15. The Exchange District. Website. Historic Exchange. Accessed Dec 25, 2014. http://www.exchangedistrict.org/toursattractions/historic-exchange/

16. MTS Centre. Website. Quick Facts. Accessed Dec. 25, 2014 http://www.mtscentre.ca/mts-centre-information/quick-facts

17. Manitoba Hydro. Website. Building Facts. Accessed Dec. 25, 2014. http://www.hydro.mb.ca/corporate/mhplace/quick facts_building.shtml

18. 5468796 Architecture. Website. Accessed Dec. 25, 2014. http://www.5468796.cal

19. Shilliday, Gregory. A History of Manitoba: Volume Three Decades of Diversity. Winnipeg, MB: Great Plains Publications, Ltd. 1995. pg. 178 .

20. Shilliday, Gregory. A History of Manitoba: Volume Three Decades of Diversity. Winnipeg, MB: Great Plains Publications, Ltd. 1995. pg. 186

21. lbid. pg. 190

22. $\mathrm{lbid}$. pg 190

23. City of Winnipeg. Our Winnipeg: It's Our City, It's Our Plan It's Our Time. Winnipeg, MB. 2011. pg. 02.

24. Shilliday, Gregory. A History of Manitoba: Volume Three Decades of Diversity. Winnipeg, MB: Great Plains Publications, Ltd. 1995. pg. 195. 



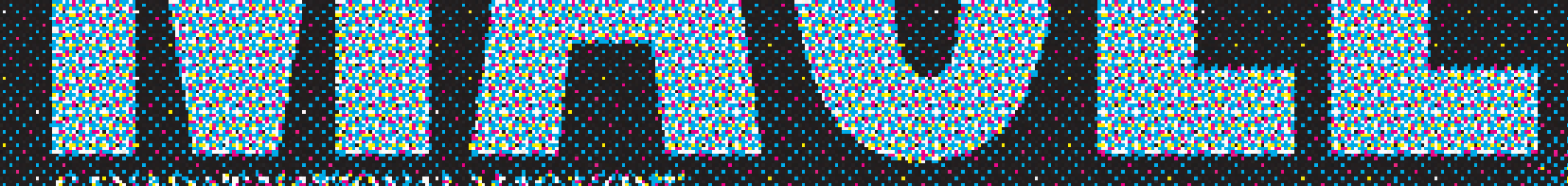

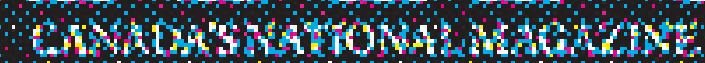

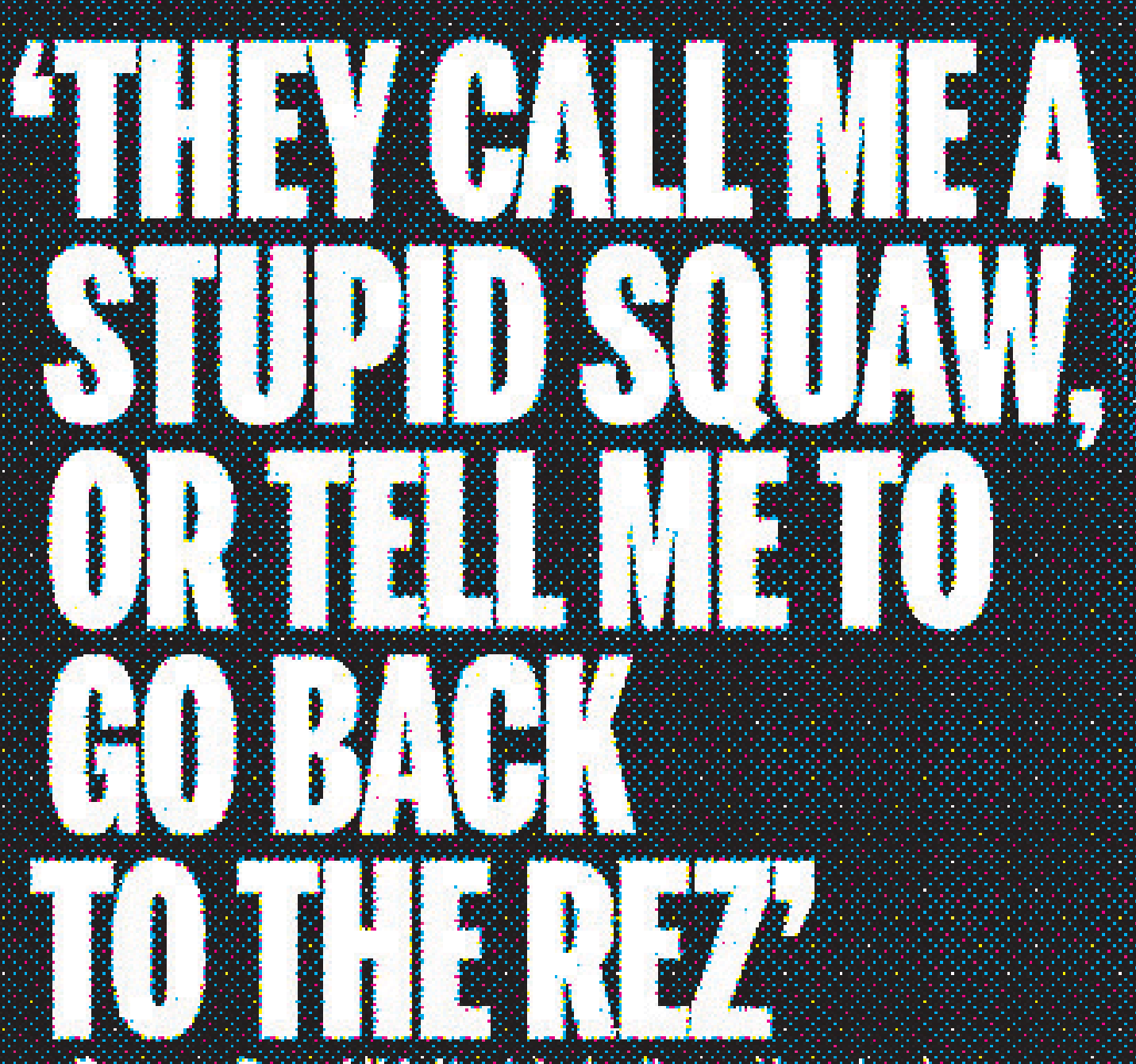

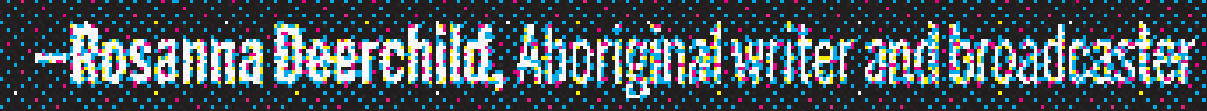

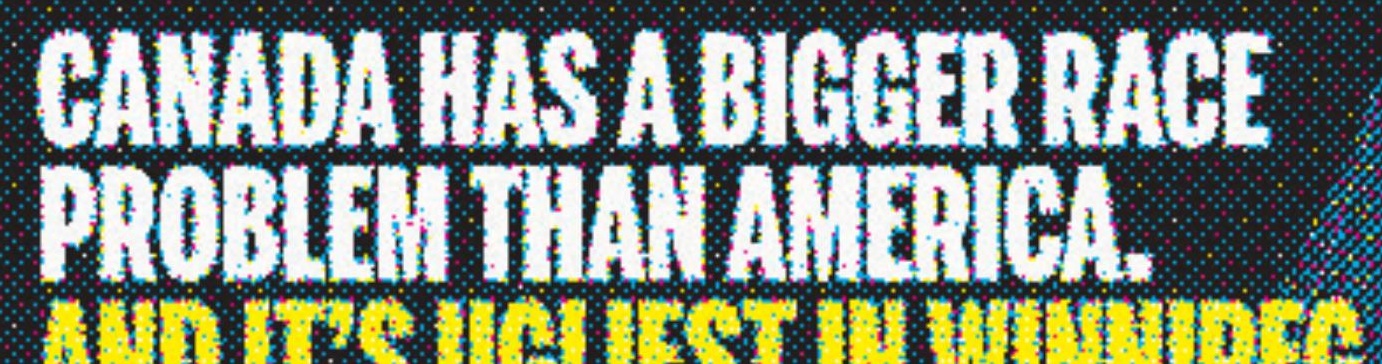


CHAPTER 7

And the Ugly:

An Architectural Intervention fig. 54. (previous page) Canada's Race Problem Madean's Magazine Cover. Feb. C2, 2015. Image retrieved from http://umw.madeans.ca/news/cansda/ coven-proviow-canadas race-problem/

"Before the European states established colonies in the Americas, Aboriginal peoples governed their own affairs. The colonial powers claimed sovereignty in North America on the basis of "discovery" but in practice their power was gradually built up by trade and settlement, warfare and diplomacy." 1 Provincial Government of the Northwest Territories.

Aside from Winnipeg's slow and steady push for physical change of its urban downtown core, the city has also seen a tremendous shift in the way its Aboriginal communities are viewed and treated, and not in the positive direction. Winnipeg, having one of the largest Aboriginal populations of any Canadian city $(17 \%$ of Winnipeg's population6, which is up $5.87 \%$ from 2011 Statistics Canada ${ }^{7}$ numbers), has had more than its share of racial outbreaks for decades. In the February 2015 article Welcome to Winnipeg: Where Canada's Racism Problem is at its Worse, published by Maclean's Magazine, recent polls conclude that Winnipeg's racism problem surpasses those of any other major Canadian city. Everything from the highest amount of racist Tweets, higher than normal rates of hatecrimes involving Aboriginals in some manner, to where only 50 percent of 
Winnipegers "would be comfortable being in a romantic relationship with an indigenous person"8 - the city is at the frontlines when it comes to racism against Aboriginals.

So how is it then, that Winnipeg, a city known for a mosaic of cultures and races - in which they celebrate their diversity with an annual two-week event called Folklarama - became this way?

Niigaan Sinclair, who teaches Native studies at the University of Manitoba, tells Maclean's Magazine he believes that it started from the beginning: Winnipeg's violent roots, the Red River Rebellion led by Louis Riel and his supporters, followed again by another "even bloodier Northwest Rebellion ${ }^{15}$ years later, creating generations of animosity." 6 Others, like playwright lan Ross believes this tension and discrimination "is largely borne of fear - 'that Indians are getting something you don't have.'"6 Resentful comments, such as Aboriginals getting free postsecondary education, or how they are able to hunt any animal any time of year, or that they are all entitled to free land, are the types of hearsays that have inundated the city for decades - as a long time resident of Winnipeg myself, bitter remarks like these are all too commonly heard.

Physically, like many large cities, there is a clear distinct division amongst the neighborhoods of those who are well off, and those who are at the cusp of living on the streets - Winnipeg is no different. Winnipeg's North End community, which is characterized by the physical division from the rest of the city, by the $\mathrm{CP}$ rail yards is home to many of Winnipeg's Aboriginal communities, but it is also Canada's "poorest and most violent neighbourhood... The neighbourhood is home to two of the country's three poorest postal codes - the median household income in the North End is $\$ 22,293$, less than 
half of the wider city at $\$ 49,790 .{ }^{\prime \prime}$

Through the countless articles, reports, readings, and polls investigated what emerges fare several common themes which include: Identity, Equality (or Equal Representation), and Education (in many cases, the lack of).

To gain a better understanding of what all these investigations and themes were unraveling, an official meeting with the Treaty Relations Commissionaire of Manitoba Jamie Wilson and his assistant Darren Courchene was re-examined.

$$
\text { For Aboriginal people, }
$$

as many other cultures and communities, an important part of

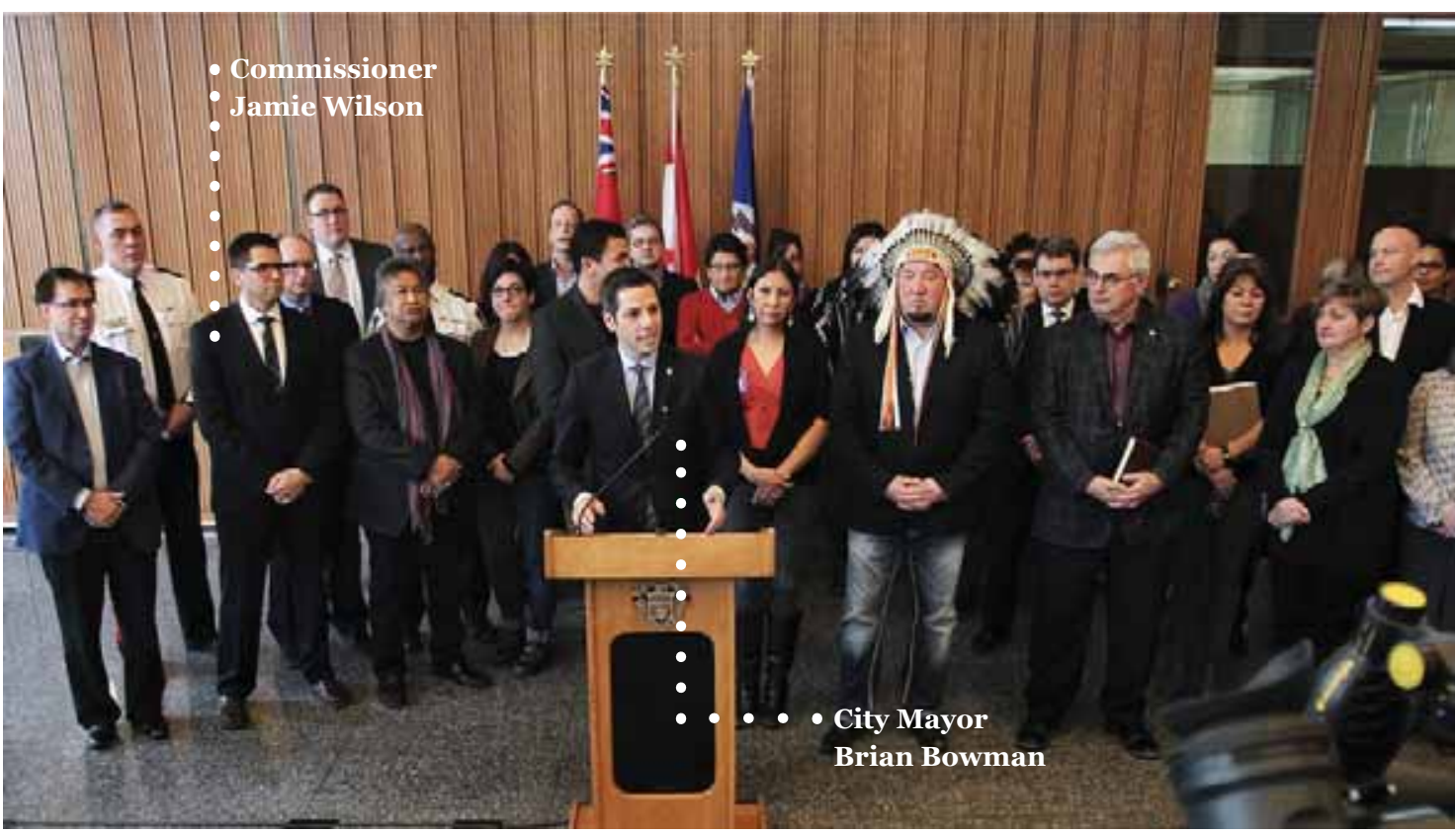

fig. 55. Manitoba Treaty Commissioner Jamie Wilson, along side other high officials at Winnipeg's City Hall. The press conference was held by city mayor Brian Bowman, city officials, and Aboriginal leaders in response to Maclean's Magazine article Canada Has a Bigger Race Problem than America. And it's Ugliest in Winnipeg. Feb. 2015. Image retrieved from http://www.macleans.ca/news/canada/for-the-record-winnipegs-political-leaders-condemn-racism/

their Identity is their oral culture and its traditions. Better explained to me by Manitoba Treaty Commissionaire James Wilson, oral culture is one of the many important traditions for Aboriginal people, and it plays a very significant role in sustaining their history, along with their identity. And throughout the colonization, the voices of Aboriginals have slowly 
been smothered, long considered a large contributor to their suppression and loss of identity. The Canadian Government's implementation of the *Residential Schooling Programs for Aboriginals not only nearly eradicated their language, but was also seen as a large contributor to the fragmentation of their once close-knit Aboriginal family unit, which has had a profound impact often resulting in substance abuse, incarceration, sexual-abuse, and of course further loss of identity.

Equity, or Equal Representation was another theme highlighted by Commissionaire Wilson. My own confessions of being somewhat biased of what the Treaties were, and who they implicated were brought to the surface, as Commissionaire Wilson explained that this was common for many individuals. "I think as people understand the Treaties more, they understand what the relationships should look like, and they understand that there's huge opportunities to work together, and that it was about a partnership." 9 Commissionaire Wilson also pointed out how inequalities exist on many levels for the community, ranging from education, employment, and for some it was about "having a voice, they feel voiceless, powerless. But I think it has to do with this equity

\section{A national disgrace}

By almost every measurable indicator, Canada's Aboriginal population suffers a worse fate and more hardship than the African-American population in the U.S.

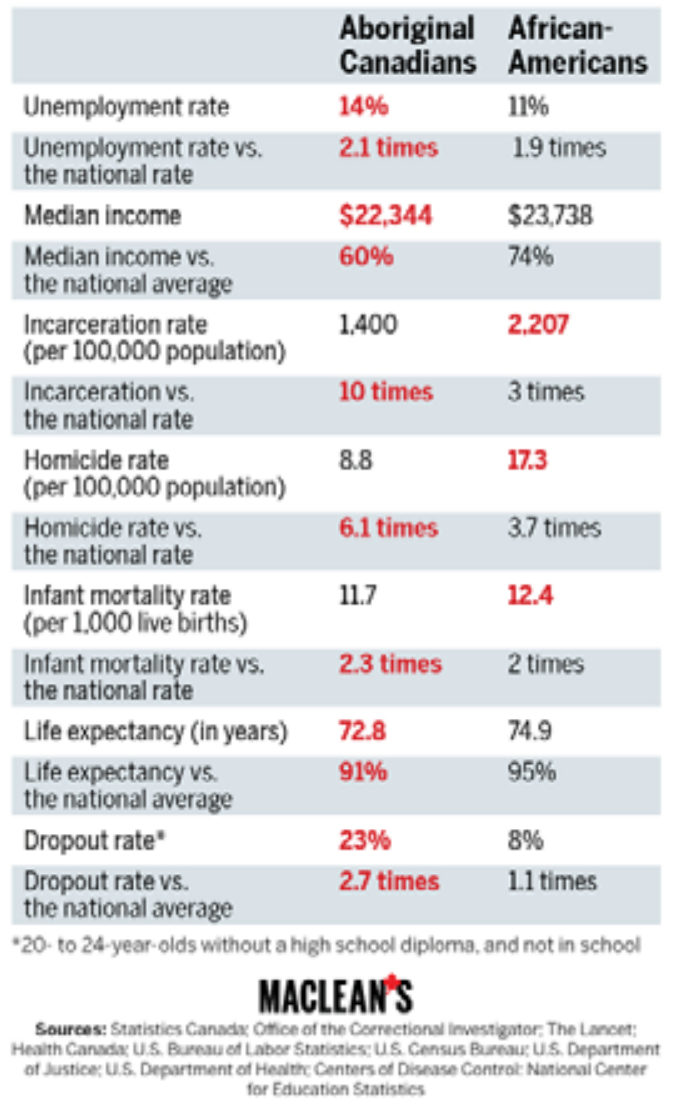

fig. 56. Image retrieved from http://www.macleans.ca/ news/canada/out-of-sight-out-of-mind-2/ 
issue." 10

When it comes to Education, attracting qualified teachers to teach on Aboriginal reserves is a large obstacle to overcome, as Treaty Commissionaire Jamie Wilson stated in his February 2015 article interview Welcome to Winnipeg: Where Canada's Racism Problem is at its Worse with Maclean's Magazine8. Commissionaire Wilson is a large advocate for the accessibility to education for Aboriginal youth and points out that all youth, regardless of race, will one day be part of the larger workforce, and when it happens, do we (as citizens) want to create "a skilled, educated workforce or an army of under-employed, undereducated indigenous youth dependent on government assistance and services?" 8 This theme is also extended by Commissionaire Wilson and his office to the notion of educating the public on the roles of the Treaties today, and how they can benefit everyone, not just Aboriginals as it is often assumed.

Over that past decades, the Canadian Government (also know as The (rown) has made numerous attempts of reconciliation between the Aboriginal community and themselves - some successful, some not. What appears to be lacking for the Aboriginal community is to have both
It thought their best chance for success was to learn English and adopt Christianity and Canadian customs. Ideally, they would pass their adopted lifestyles on to their children, and native traditions would diminish, or be completely abolished in a few generation." - CBC News. A History of Residential Schools in Canada: 
a public and political representation that personifies their values, beliefs and identity; something that can act as mediator, and offer equal representation for their community.

\section{Culmination of Research}

These aforementioned themes

- Identity, Equity, and Education - are all thus embodied within the notion of an Embassy, architecture here serving as a physical vessel for their voice once silenced - the empowerment of a community and people.

With the implementation and introduction of an Aboriginal Embassy, the community would be conveying to the rest of Canada that they desire to be recognized as a distinct nation, with beliefs and values, which may not always coincide with those of their colonizer, and that diplomatic ties and negotiations are necessary for their continued coexistence and equal treatment on both government and community levels. $\infty$ 
* Residential School Program: "In the 19th century, the Canadian government believed it was responsible for educating and caring for aboriginal people in Canada. It thought their best chance for success was to learn English and adopt Christianity and Canadian customs. Ideally, they would pass their adopted lifestyles on to their children, and native traditions would diminish, or be completely abolished in a few generation."

CBC News. A History of Residential Schools in Canada: FAQs on Residential Schools, Compensations and the Truth and Reconciliation Commission. May 16, 2008. Accessed January 19, 2015. http://www.cbc.ca/ news/canada/a-history-of-residentialschools-in-canada-1.702280
Endnotes.

01. Government of Northwest Territories. Aboriginal People and the Crown: A Changing Relationship. Introduction. PDF document. pg 3. Accessed January 19, 2015. http://www.gov. nt.ca/publications/asg/pdfs/abor.pdf

02. Wilson, James. Manitoba Treaty Commissionaire. Interview. December 18, 2014. Part 2. page 2.

03. Statistics Canada. 2012. Winnipeg, Manitoba (Code 4611040) and Division No. 11, Manitoba (Code 4611) (table). Census Profile. 2011 Census. Statistics Canada Catalogue no. 98-316-XWE. Ottawa. Released October 24, 2012. Accessed December 20, 2014.https://www12.statcan.gc.ca/nhs-enm/ 2011/dp-pd/prof/details/page.cfm?Lang=E\&Geo1=CSD\&Code $1=4611040 \&$ Data $=$ Count $\&$ Search Text $=$ winnipeg $\&$ Search Type $=$ Begins\&Search $P R=01 \& A 1=A l l \& B 1=A l l \&$ Custom $=\& T A B I D=1$

04. Wikipedia. Diplomatic Mission. Naming. Website. Accessed January 19, 2015. http://en.wikipedia.org/wiki/Diplomatic mission

05. Discover Diplomacy. U.S Diplomacy Centre. Diplomatic Dictionary: Chancery. Website. Accessed January 19, $2015 . \quad \mathrm{http}: / /$ diplomacy.state.gov/discoverdiplomacy/ references/169792.htm\#C

06. Macdonald, Nancy. Welcome to Winnipeg: Where Canada's Racism Problem is at its Worst. Maclean's Magazine. February 02, 2015. Toronto, ON: Rogers Publishing Ltd. 2015. p.20

07. Statistics Canada. 2012. Winnipeg, Manitoba (Code 4611040) and Division No. 11, Manitoba (Code 4611) (table). Census Profile. 2011 Census. Statistics Canada Catalogue no. 98-316-XWE. Ottawa. Released October 24, 2012. Accessed December 20, 2014.https://www12.statcan.gc.ca/nhsenm/2011/dp-

08. Macdonald, Nancy. Welcome to Winnipeg: Where Canada's Racism Problem is at its Worst. Maclean's Magazine. February 02, 2015. Toronto, ON: Rogers Publishing Ltd. 2015. p.24

09. Wilson, James and Darren Courchene. Interviewed by Jagtar Singh. Conversation with the Commissioner. Winnipeg, MB. 18 December 2015 pt.1 - 2:10 mins.

10. Ibid. pt. 1 - 03:30 mins. 

$$
\text { H+1, }
$$$$
\text { 1, }
$$

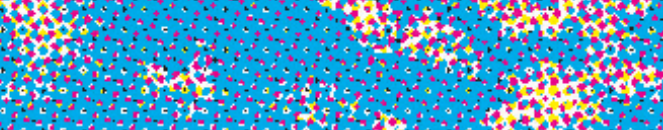$$
\text { 4. }
$$

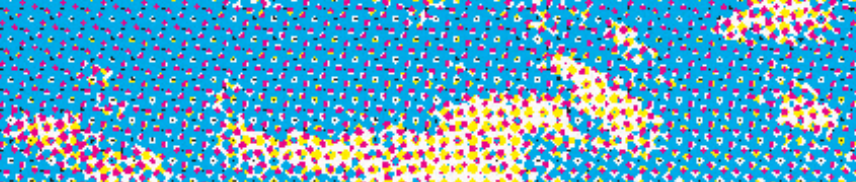

W.

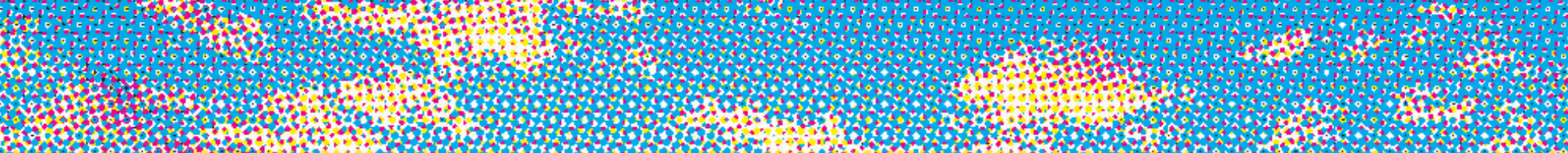

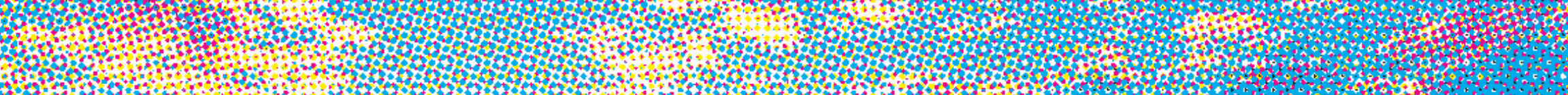

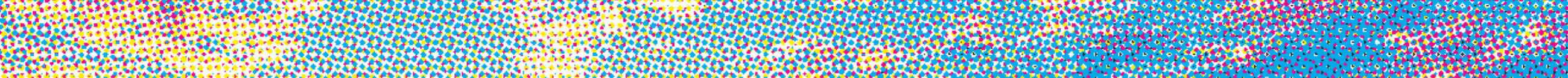

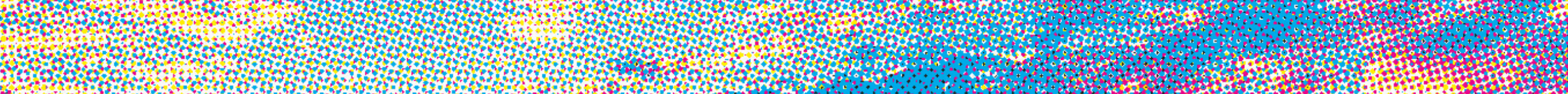
W
W

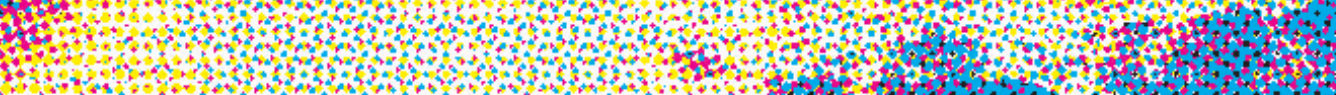
tom 6 .

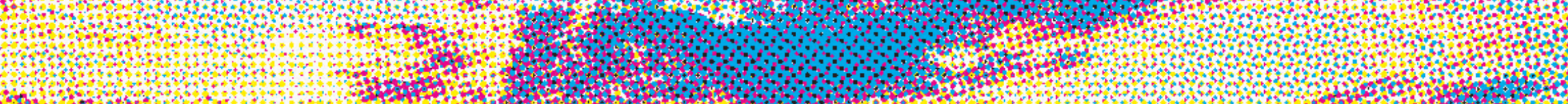

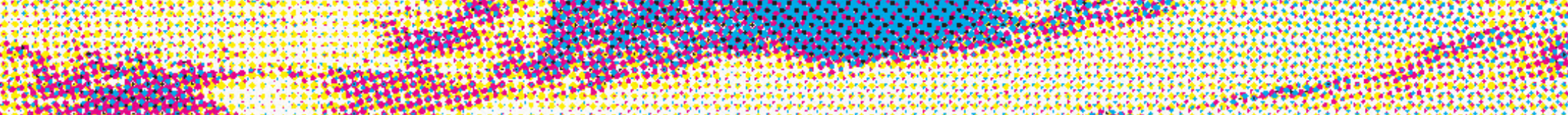
H.t.m. 
CHAPTER 8

Project Portfolio:

an Aboriginal Embassy

"... an oasis in the desert... a spot upon the moon, or a solitary ship upon the ocean." - R.M. Ballantyne, British author and clerk for The Hudson's Bay Company at Red River; when describing The Forks site in the early 1820 s.

Before commencing these thesis investigations, what had become the subject in question was "Why is the conservation of The Hudson's Bay Company department store of importance to the city of Winnipeg, but more importantly for Canadians?" As a longtime native resident of Winnipeg, The HBC department store on Portage Avenue was always a prominent piece of Winnipeg's architecture within its urban landscape, and over the decades, the slow and steady decline of the building's upkeep and accelerated deterioration was becoming more and more apparent.

The HBC department store in downtown Winnipeg, which is nearing its 90th anniversary, has been in constant limbo for several years now, with recent rumors that it will be converted to a Saks Fifth Avenue outlet (The HBC recently acquired the Saks \& Company in July 2013) ${ }^{1}$; this also includes plans to convert parts of the department store to offices. As of today April 2015, three of the 
store's seven floors (levels one/main, two, and four are only accessible to the public), are being used for their retail operations, the remaining floors are inaccessible.

What would an embassy represent for Aboriginals, and what could it achieve for them?

Consequently, this enquiry has taken on a new agenda; the building became more about saving a Nation, or at the least, acting as a catalyst to help restore and empower a community - architecture serving a social agenda, as agency, playing the role of a voice for the Aboriginal community.

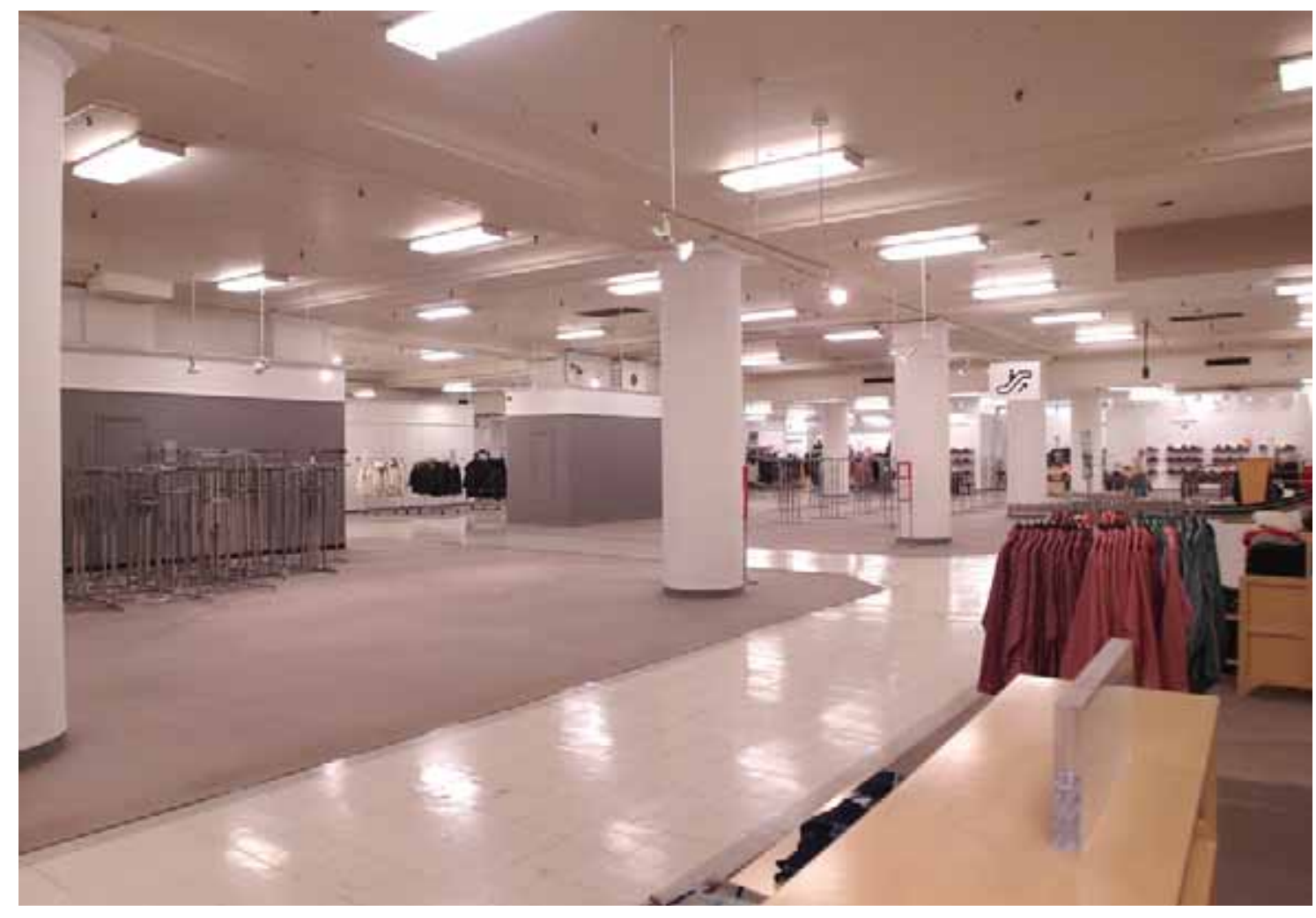

fig. 58. Current state of the near abandoned Second floor of The HBC department store. Winnipeg, MB. Photograph Personal Collection. 2014

The aim was to not just build an edifice - or in this instance readapt the building - but to create an architecture that would represent and recall the richness of the Aboriginal people, their culture, their values, and their beliefs. The sovereign government bodies of 
the *Aboriginal community need an appropriate permanent home. Therefore not just the building, but the architecture itself will need to play an important role in serving as one of the many facets on how Canadians begin to view Aboriginals and their narrative - with greater importance and relevance. Through this building, the architecture will be used to encourage ideologies of dignity, equality, acceptance, independence, mutual discussions, and also a deep profound respect for not only for others, but nature, the land that we all live and depend on.

\section{Role of an Embassy}

An embassy, which is more specifically described as a diplomatic mission, involves a group of individuals (in this case the Aboriginal People), from a state (Aboriginal Land Reserves), that is present in another state (Canada) to "represent the sending state/organization in the receiving state. A permanent diplomatic mission is known as an embassy, and the head of the mission is known as an ambassador." ${ }^{4}$

More commonly today, embassies are often referred to as the edifice in which diplomatic works are carried out - the proper term for the space used for diplomatic works is called the Chancery ${ }^{5}$. Embassies are situated in the host nation's capital city, and typically deal with the legal negotiations and political affairs. Whereas consulates are located in cities of significance of the host nation, and are more or less tailored directly for the needs and protection of its citizens (i.e. often where passport travel Visas are obtained, etc.), these offices are also under the administrative jurisdiction of the embassy ${ }^{5}$.

The role of the Aboriginal Embassy will serve as a permanent home for the community's governing bodies, not only for Manitoban Aboriginal Officials, but also for every 
Canadian province and territory. A cultural environment, where higher officials can congregate and meet with The Crown (Canadian Government) to resolve disputes, and discuss the Treaties and other related affairs. A place where cultural exchanges between governments can take place, but it also need be accessible to all individuals, Aboriginals or not. "It is and will remain imperative that [the Aboriginal Embassy] play a major role in conveying to others an appropriate impression and image of" 2 its people and ideologies.

Diplomatic customs between foreign communities are not out of the ordinary for Aboriginals, and

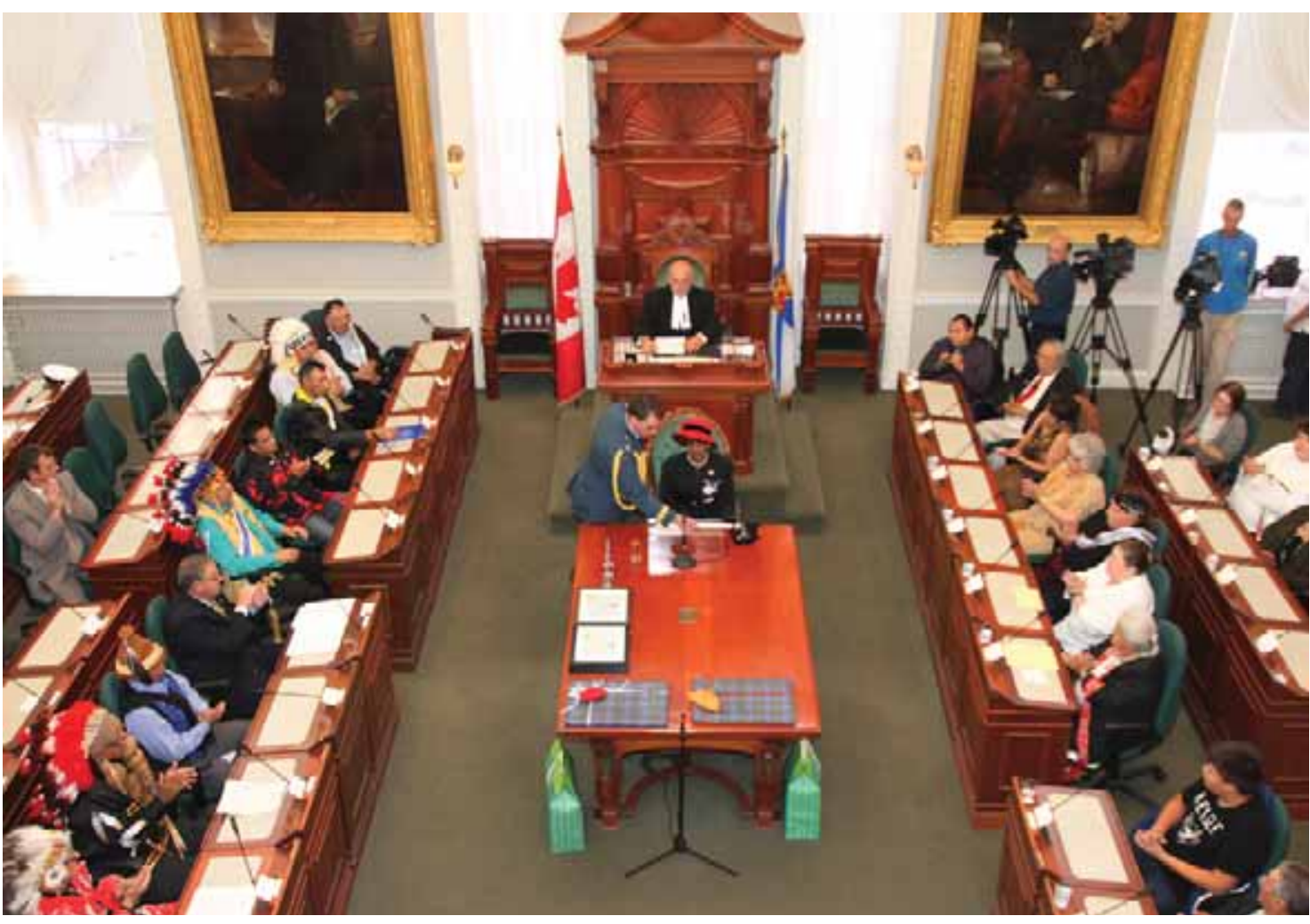

fig. 59. View of Treaty Day ceremonies from the gallery in Province House. Halifax, Nova Scotia. Photograph. Unknown. Oct. 03, 2011. Image retrived from http://novascotia.ca/news/smr/2011-10-03-Treaty-Day/

have been a part of their customary culture for centuries. Before The HBC could conduct any business on foreign soil in the New World (today
Canada), they knew that they would need the approval of the Aboriginals. Arthur J. Ray notes this in his book Bounty and Benevolence: A History 
of Saskatchewan Treaties, "In other words, in spite of having received title to Rupertsland from the English Crown, the companies directors realized that the grant meant nothing to their customers. The company had to obtain Native approval to occupy portions of their territory... All Indian nations had well-developed diplomatic/political traditions for reaching peace and other accords with outsiders." 10

\section{Why Winnipeg as Site?}

Winnipeg,

Manitoba,

the location where Treaty 1 was negotiated and signed ${ }^{11}$, had also become an important convergence of two foreign cultures, and thus is an appropriate site for an Aboriginal Embassy. And given the nature of the grand scheme proposed for The Mall of Triumph (see chapter 5) which included Memorial Boulevard, nothing short of an Embassy seems both fitting and appropriate. The Embassy is to be located within a south portion of the existing $\mathrm{HBC}$ department store. An adaptive reuse of selected spaces of the building will be utilized; the remainder will remain for The HBC and their operations.

The HBC's storefront and its main entrances are situated along Portage Avenue, facing away from the Manitoba Legislative Building; a four-storey parkade is located at the store's immediate south. As a result, the store's south-elevation directly faces the Manitoba Legislative Building some 1500 meters down. Removal of the existing parkade, will result in a 360 foot by 220 foot lot, creating an opportunity to utilize the store's south-face as the new entrance for the Aboriginal Embassy. The strategic placement of the Embassy's entrance will inevitably create and foster a dialogue with the Manitoba Legislative Building down the boulevard, which in turn restores some of the grand ideologies initially proposed for the Mall of Triumph. 
Winnipeg, Manitoba

Figure 60.

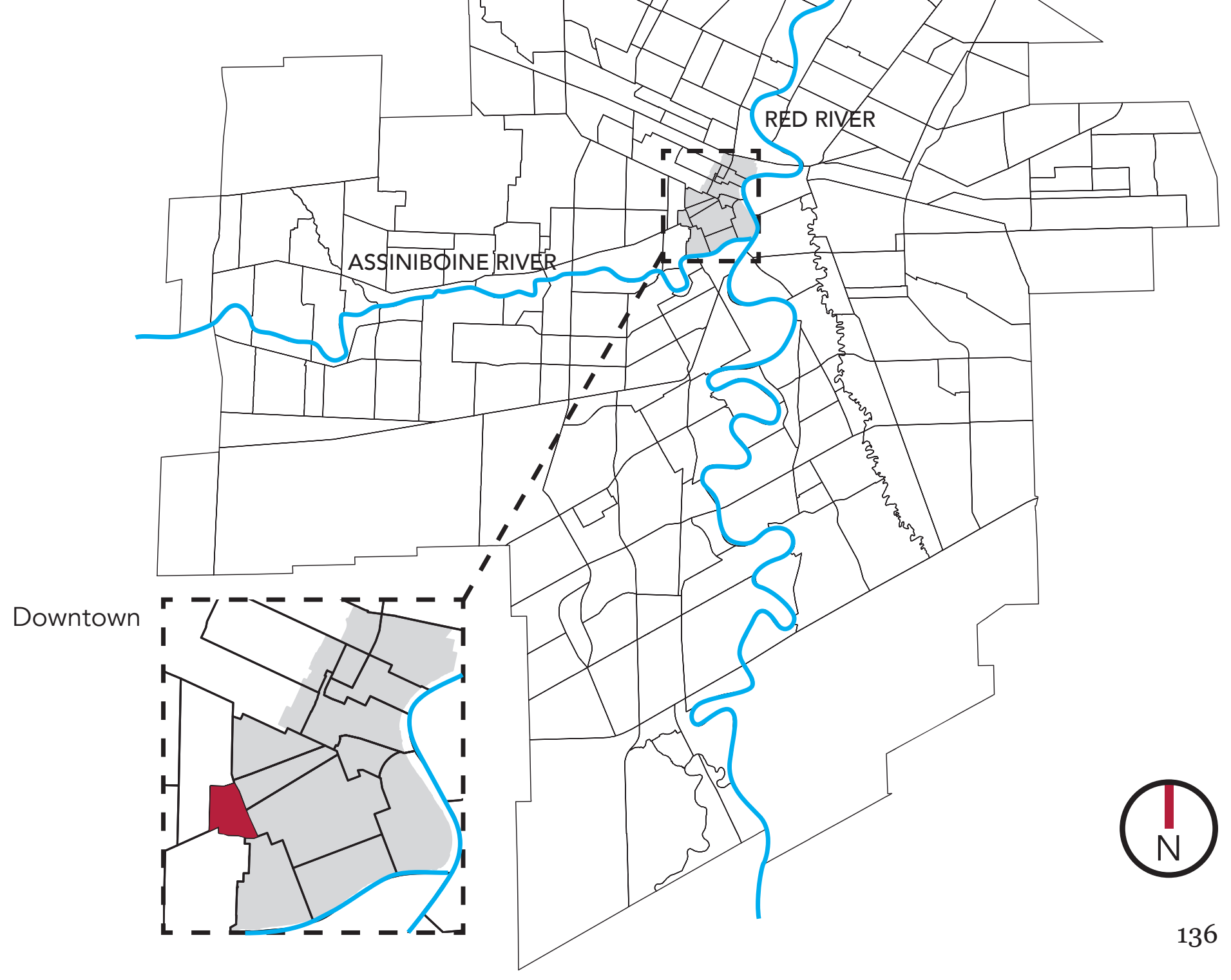


Downtown Map

Winnipeg, Manitoba

Figure. 61

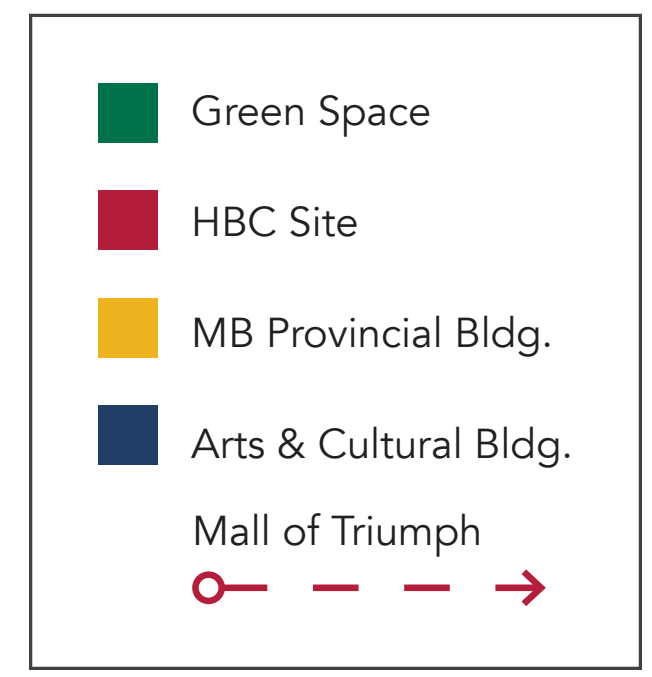

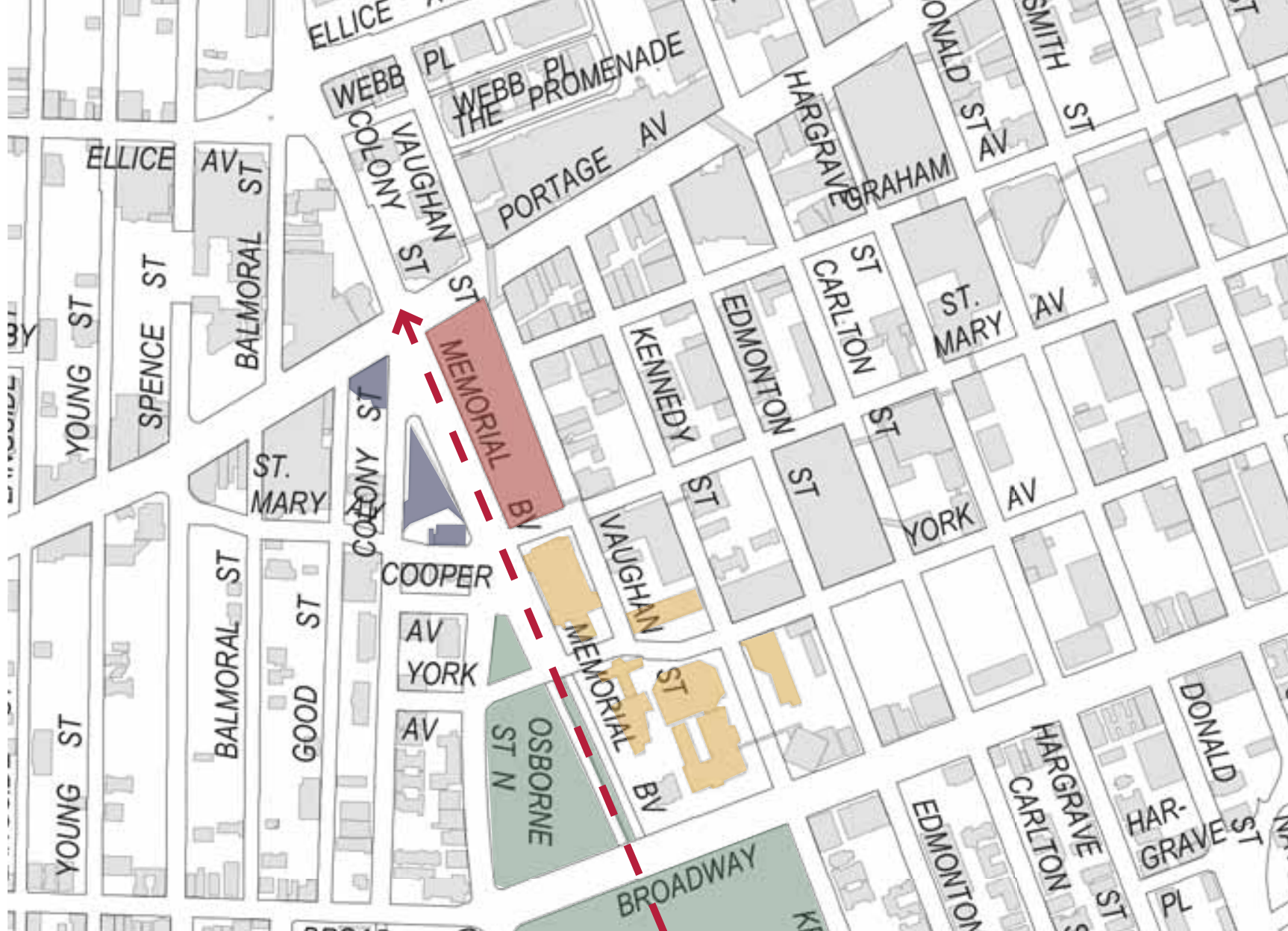

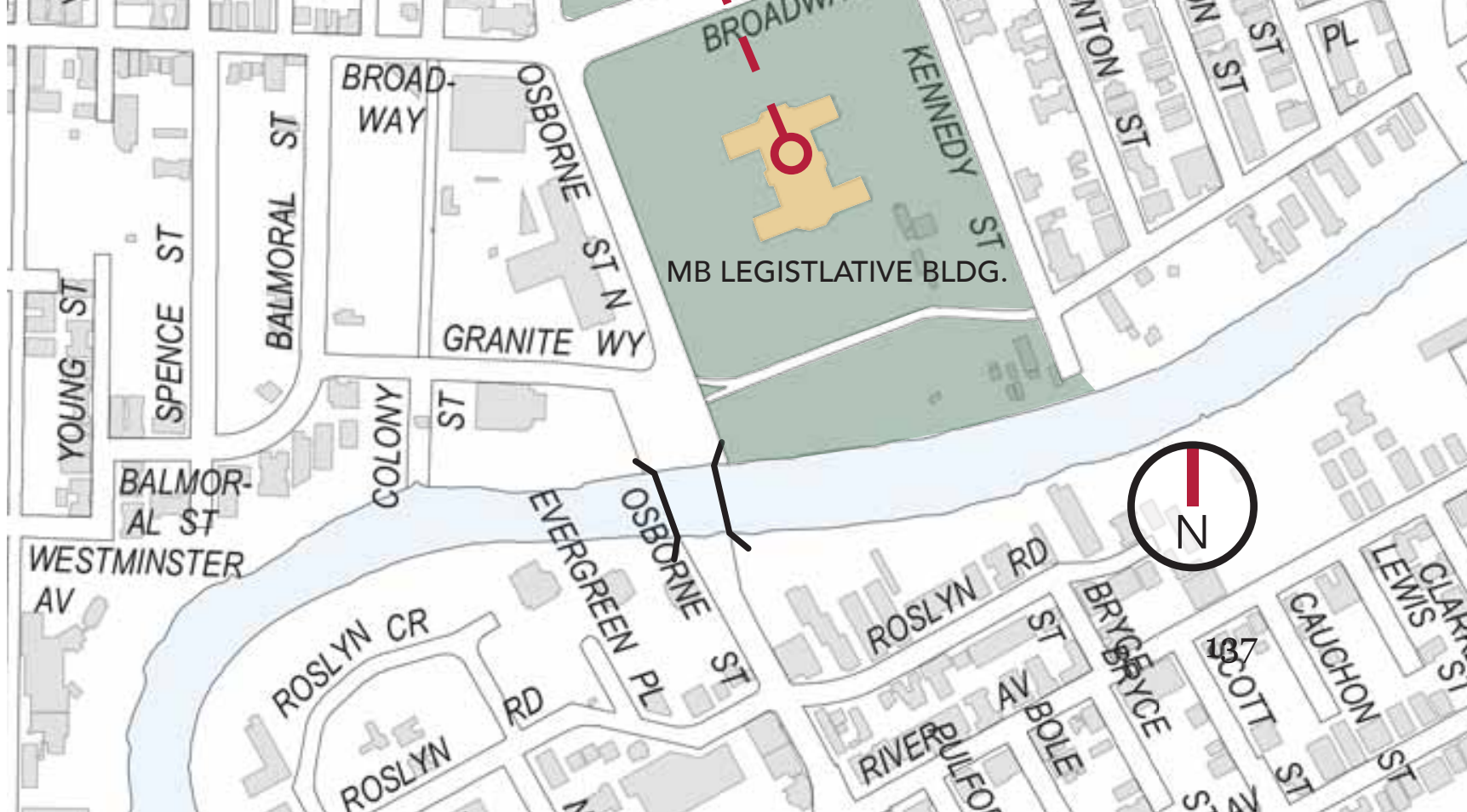




\section{VAUGHAN ST}

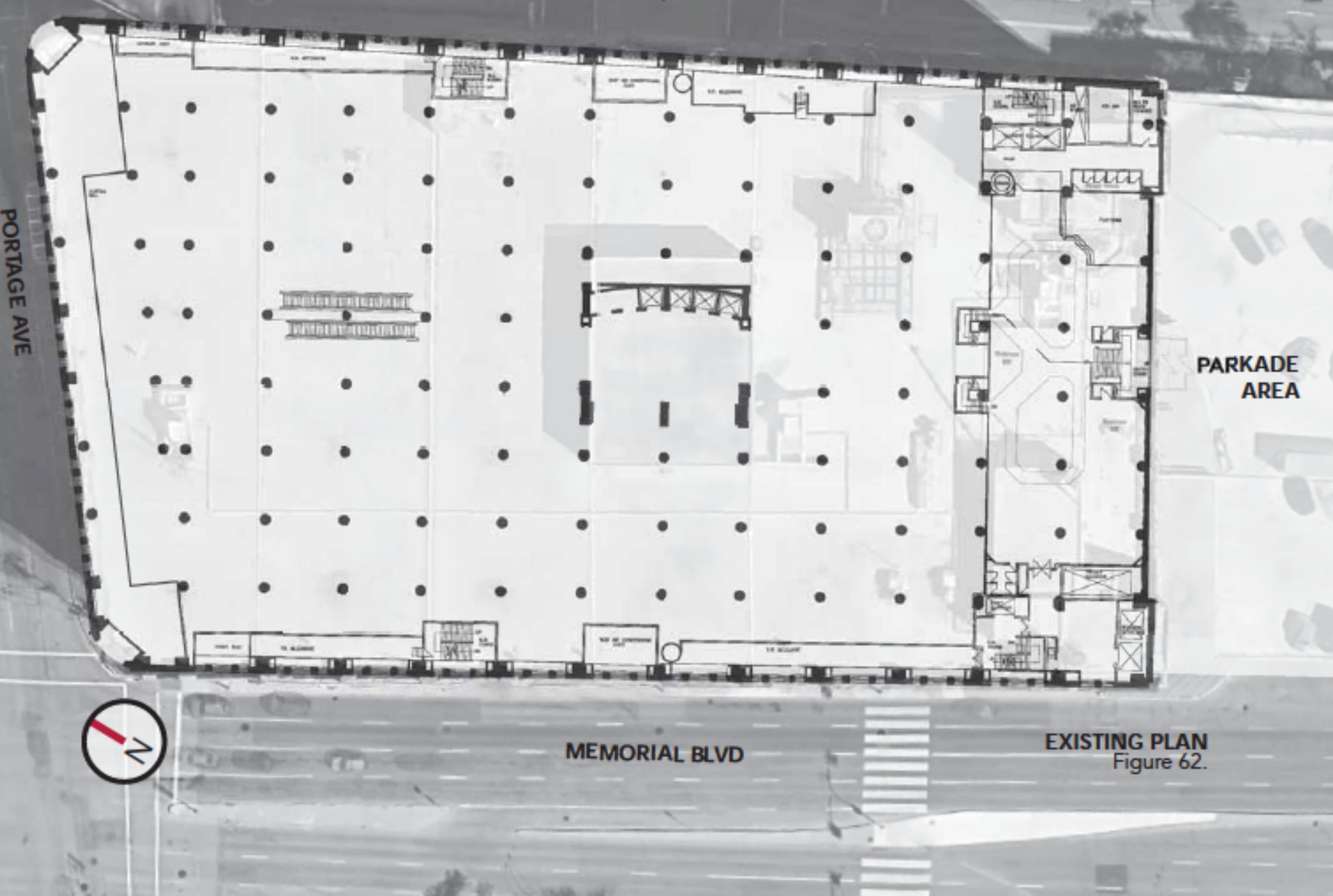




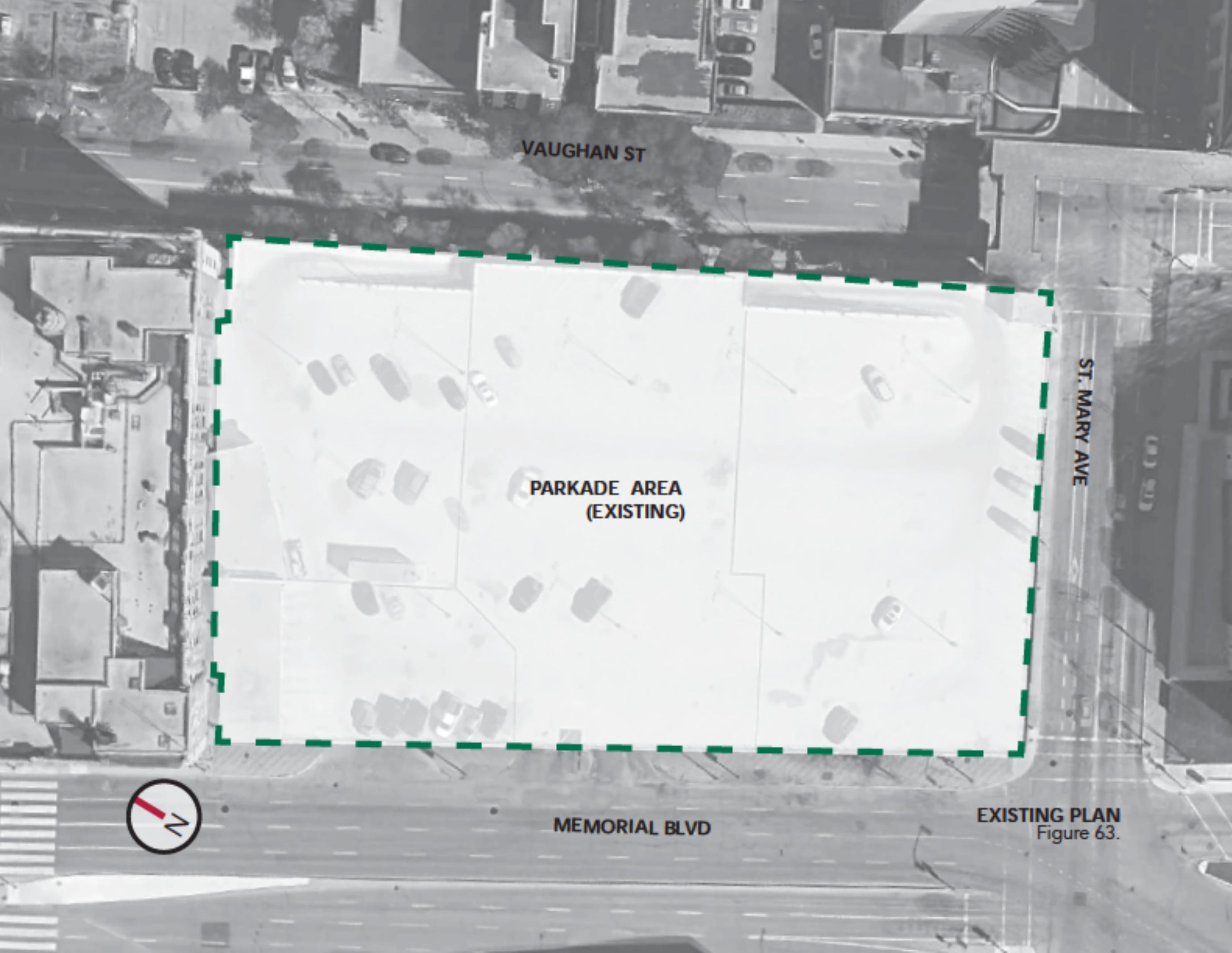




\section{VAUGHAN ST}

PROPOSED PLAN

SECOND FLOOR PLAN

scale $1 / 32^{*}=1^{\prime}-0^{\prime \prime}$

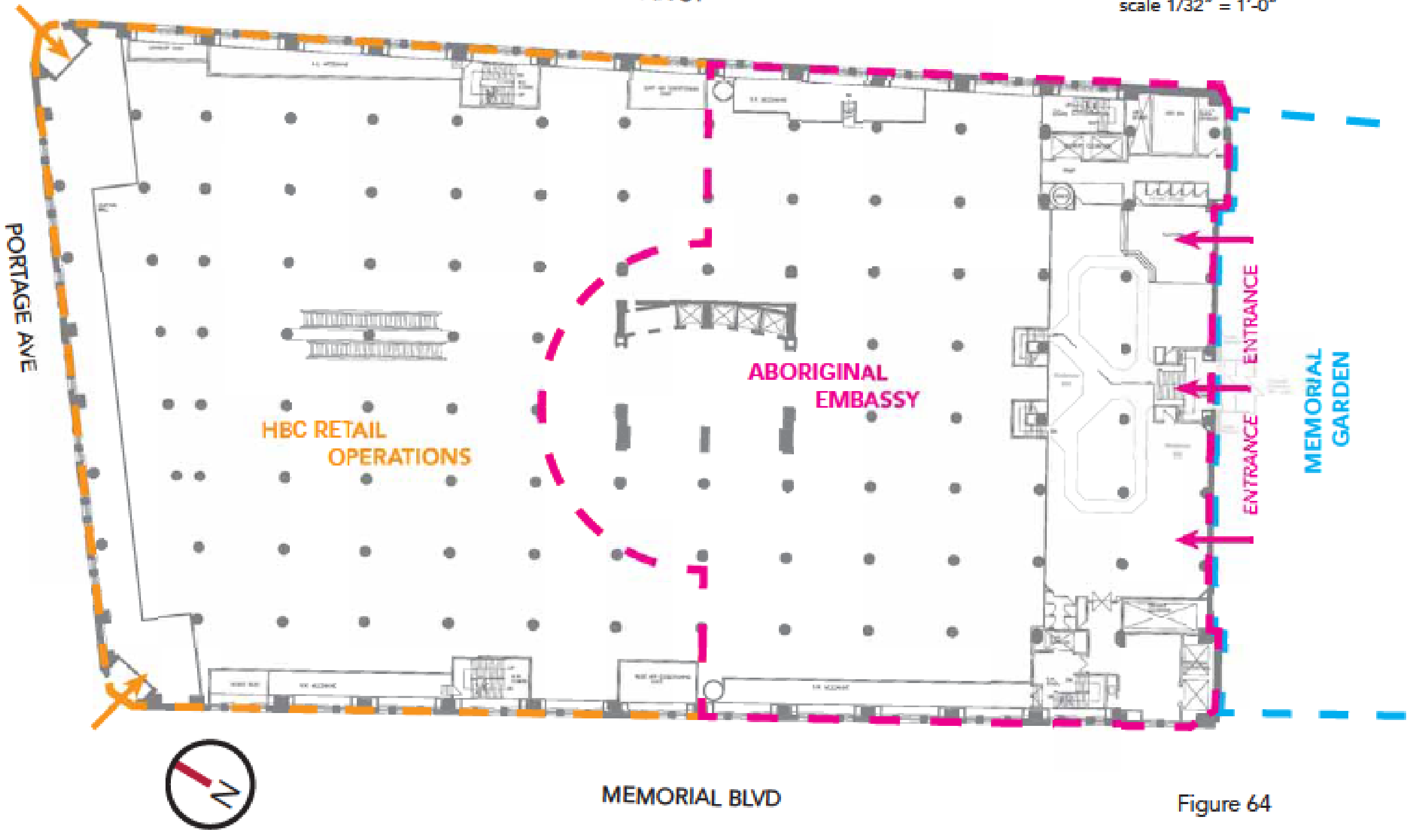


Though much of the Aboriginal architecture that has been implemented to date on many other local edifices carries with it them an amplitude and array of symbolic and representational meanings, the uses behind the symbolic nature of the Embassy are to be kept to a minimal whenever possible. Though minimalistic moves, the intent is to allow these symbolisms to resonate longer with the individual and their experience of the building and its spaces. Through selected themes, these minimalistic gestures are proposed to help personify Aboriginal values, their close connection with nature, and natural elements.

\section{Memorial Garden}

After the removal of the parkade, a site area of approximately 80,640 square feet allows for a memorial garden to be established at the Aboriginal Embassy's entrance. Slowly ramping up to the second floor of The HBC department store - which is where visitors enter the Aboriginal Embassy - the garden is intended to be a place of convergence and contemplation throughout the year. A mixture of hard and soft-scape surfaces, comprised of Tyndall stone steps that gradually become inundated with Tall Grass Prairie as one moves up through the garden towards the Embassy's entrance.
Both Tyndall stone, and Tall Grass Prairie are native and locally sourced materials in southern-central Manitoba. Tyndall stone, a type of limestone quarried in and around Winnipeg, is characterized by its cream colour, but more specifically known for its sedimented marine creatures when the stones were formed 7 . Tall Grass Prairie is an ecosystem, which was typically common around the American Midwest and parts of Central Canada and, as its name indicates, it is characterized by various tall grasses that include Indiangrass, Big Bluestem, Little Bluestem, and Switchgrass. These stalks of grass grow anywhere between 4.9 feet 
to 6.6 feet (1.5 to 2 meters), but have reached heights of 9.8 feet ( 3 meters $)^{8}$.

The notion surrounding the gradient of tall grasses that increase as the individual nears the top at the Embassy's entrance is reminiscent of the undisturbed flourished landscape before the permanent settlement of the land. On a more profound level, it is also symbolic of the government's attempt to silence the voice of the Aboriginal community but, just as nature does, it always manages to prevail and find its way through the cracks of concrete sidewalks the once suppressed voice of the Aboriginal community will and must find its way to be heard. Aboriginal culture and livelihood necessitate a profound connection with the natural environment from which they depend on for their resources.

The Memorial Garden is equally divided into three parts, each representing the three founding pillars of Canada - English, French, and Aboriginal. The center path is representative of the Aboriginal people, and is also the only path that directly leads to the Embassy's entrance. The other two paths on either side (representing the English and French communities) serve as areas of congregation and meditation, and each open assembly area is representative of an important and significant event in the formation of Manitoba, and or Winnipeg (i.e. Red River Rebellion, Battle of Seven Oaks, Treaty 1, etc.) 


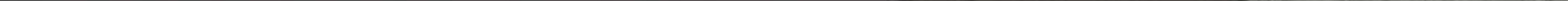


FRONT

ELEVATION

scale $1 / 32^{\prime \prime}=1^{\prime}-0^{\prime \prime}$

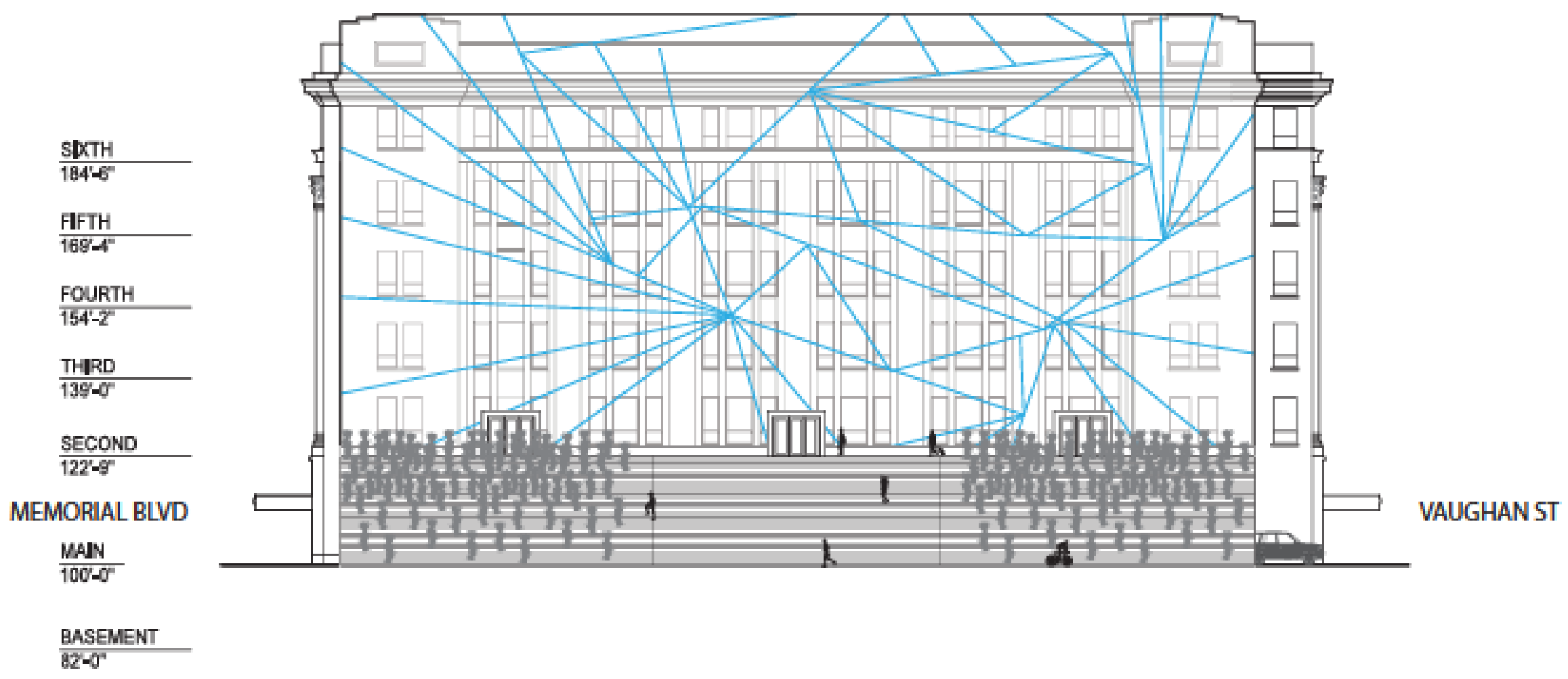

Figure 66 . 


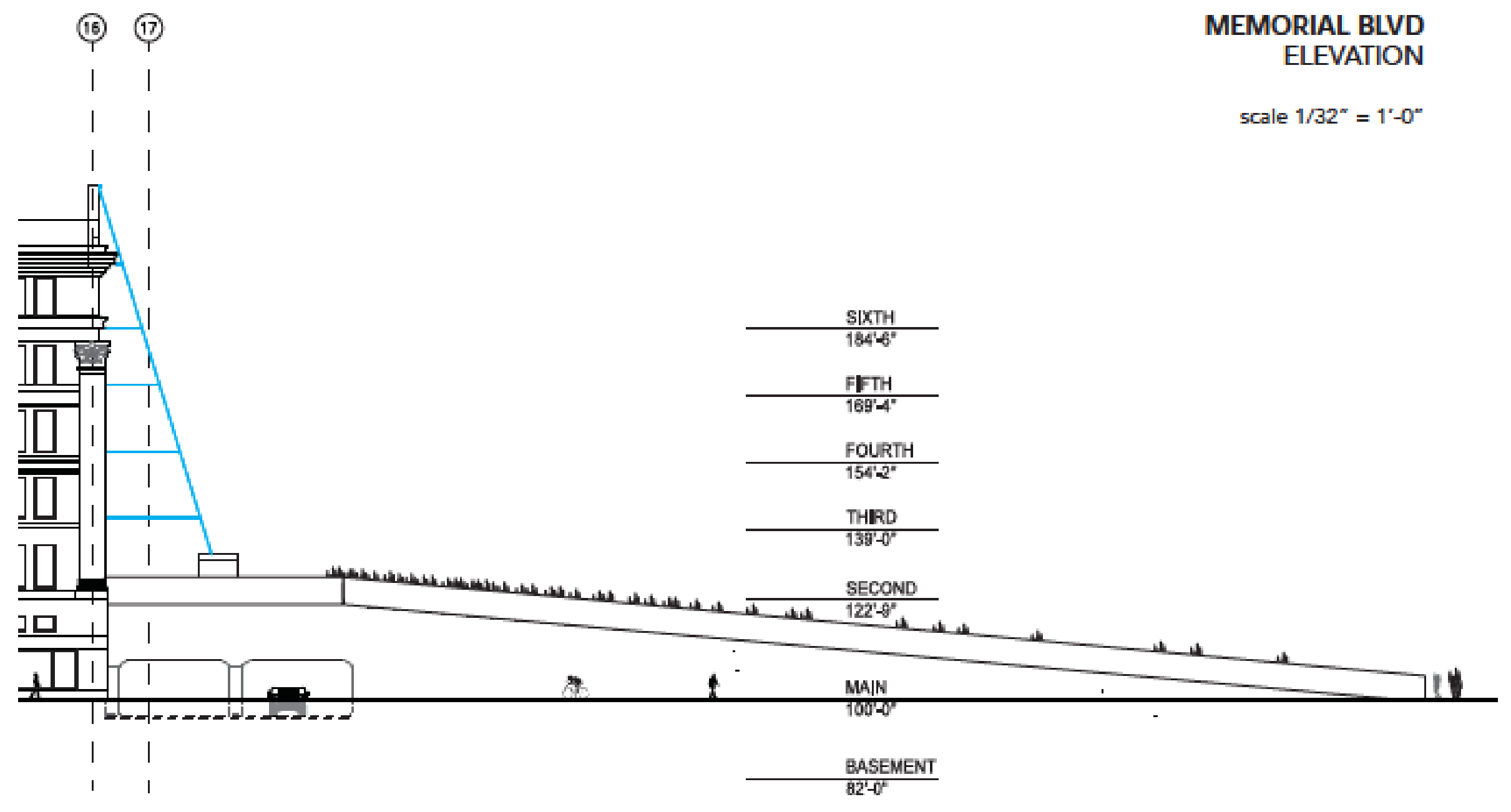

Figure 67. 
VAUGHAN ST

ELEVATION

(19) ()

scale $1 / 32^{*}=1^{\prime}-0^{\prime \prime}$

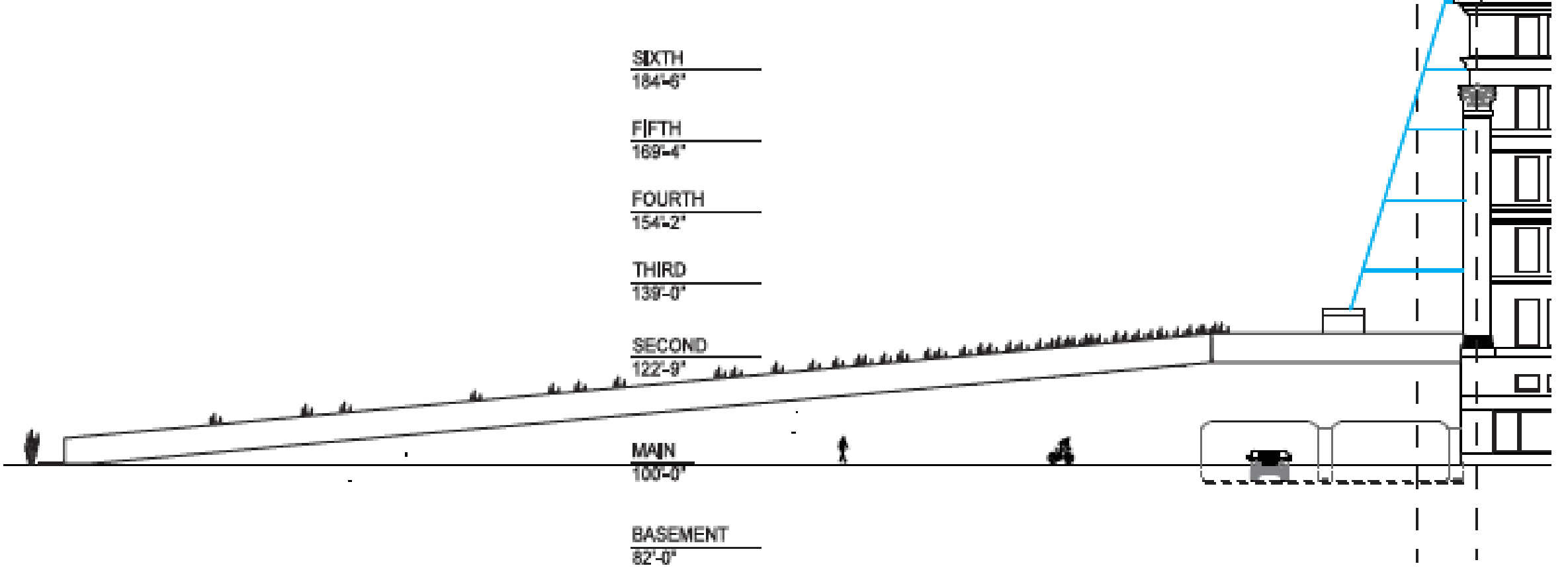

Figure 68 . 
(16) (19)

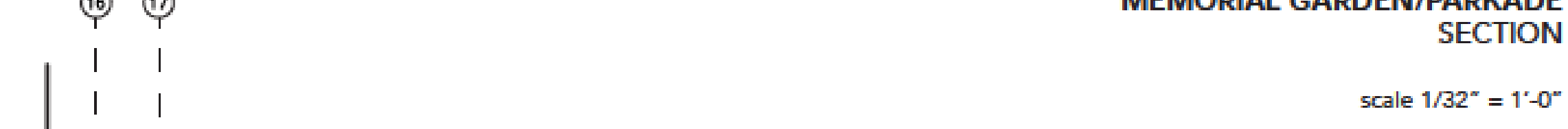

Figure 69. 


\section{Embassy Facade}

From the foot of the Memorial Garden, it is evident that the front façade of the Aboriginal Embassy is comprised of a large glass curtain wall. The mirrored glass-curtain wall inevitably reflects the surrounding sky above, which is again symbolic of the landscape and vast openness of the seemingly infinite horizontal Prairie plains. The absence of tall buildings surrounding the Embassy make it possible to reflect the sky without obstructions and the reflections of other edifices.

Window mullions of the mirrored glass façade do not run completely vertically from top to bottom, but are an abstract depiction of shattered glass. This shattered glass is representative of the Aboriginal family unit that was fragmented by the implication of the Residential Schooling Programs by the Government of Canada throughout the Nation - the aim is not to provoke those observing the Aboriginal Embassy, but serve as a reminder of what transpired and how the Aboriginal community was treated; and in some instances, still is today. 


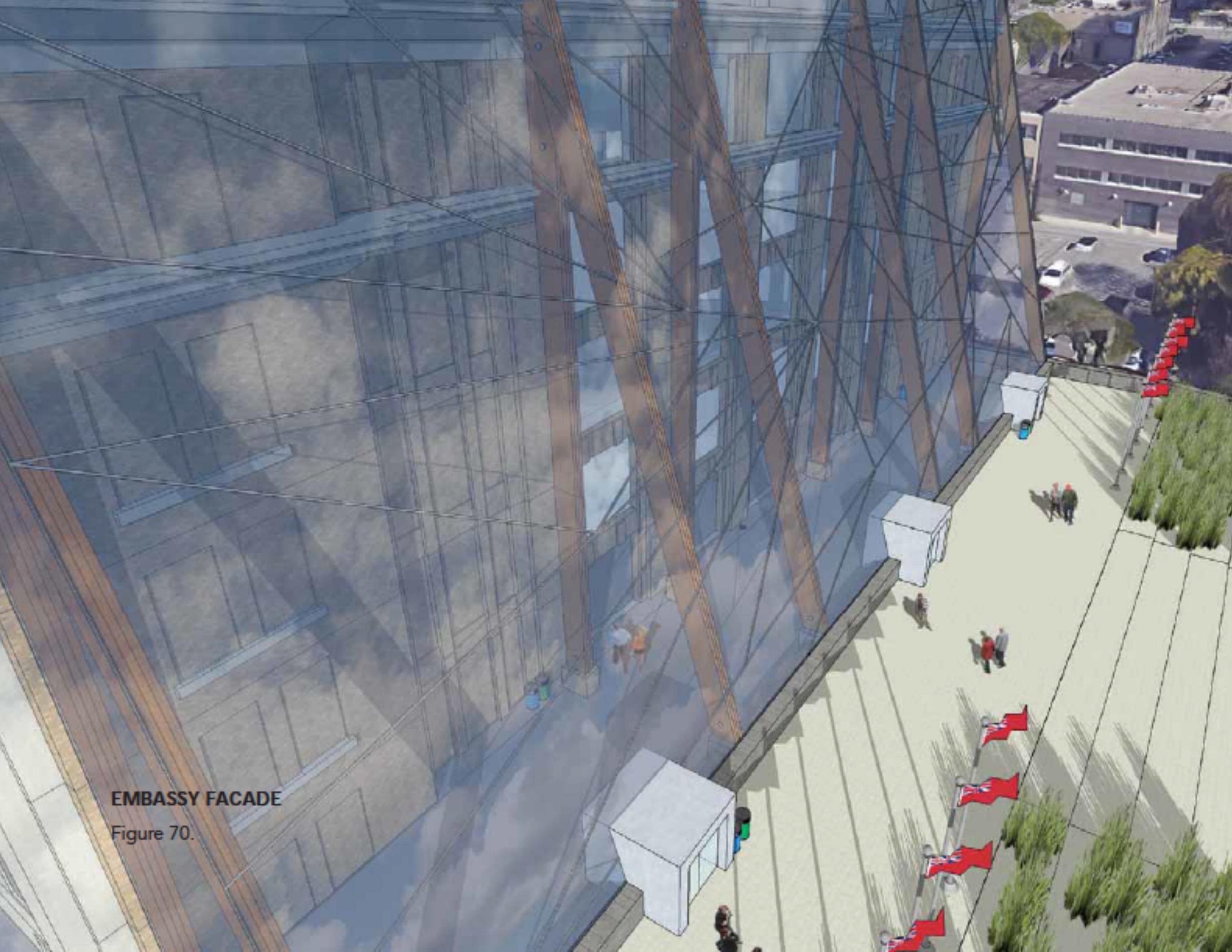


Lobby Entrance (level 2M)

Entering any of the three entrances, the visitor is presented in the main floor (second floor of The HBC store) of the atrium with a 95-foot high space showcasing the department store's original yellowbrick architecture. Visitors can also observe the plentiful amount of natural light that enters the vertical space, naturally illuminating it during the day (Winnipeg is known to have one of the highest averages of sunlight hours per year of any Canadian city - approximately 2,372 hours $\left.{ }^{13}\right)$. The multitude of widows along the original brick wall allows visitors to see a glimpse of events that are occurring throughout sections of the Embassy.

Starring straight ahead, the low laying ceiling into the main floor of the Embassy creates a seemingly darker environment, as the numerous original concrete pillars line the seemingly deep and quiet space. Within this darker space, strips of light penetrate through the darkness at its far end, simultaneously creating feelings of hesitation and curiosity, inviting the visitor to explore the space ahead.

Moving into and throughout the darker open space, visitors are presented with various images, artifacts, and motifs representing
Aboriginals and their struggles throughout various historic events another memorial of sorts, becoming a place to reflect and contemplate the hardships of the community. 


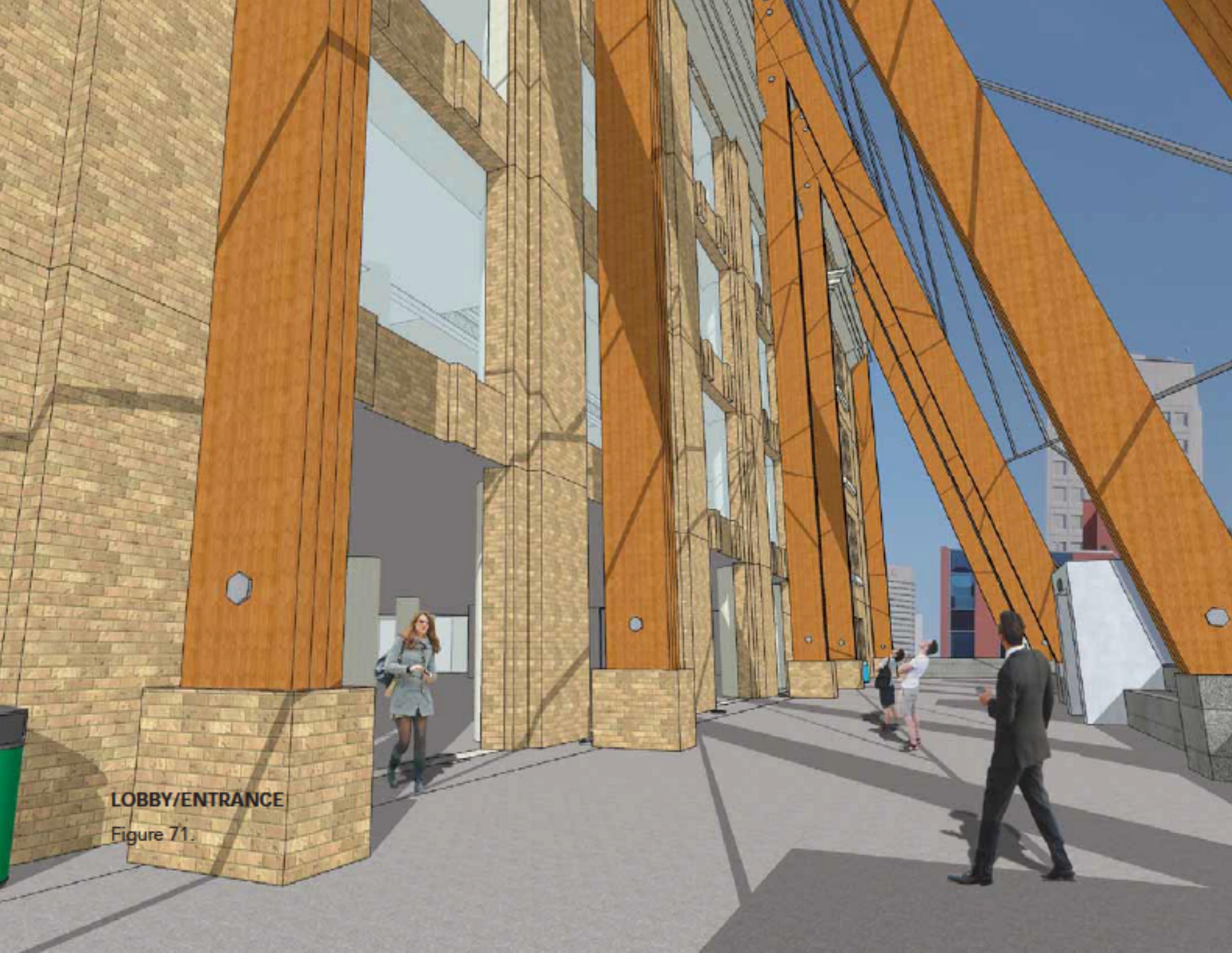




\section{Sun Atrium (level 2M)}

Both drawing and navigating the visitor to its natural light, the Sun Atrium stands as a large naturallylit open volume, which is further intensified, after having traversed the shallow darker space of the main floor area. The one-hundred-and-eight foot diameter of the atrium space functions as the main formal space for cultural exchanges (i.e. Sunrise and Smudge ceremonies, Powwows, etc.) between governing bodies. Throughout the rest of the year, the space is left for visitors and patrons to sit within and enjoy its sunlight and openness.
At each floor level, the atrium's diameter reduces in size, creating a conical volume within the atrium - this is evident when viewing the building in section (see following page).

At the top of the Suntrium, an abstract glass form teepee-like structure points to the northeast. Its design is two-fold; it allows a substantial amount of direct natural light to penetrate within the dark concrete edifice, and also points east towards the sacred sunrise, where the Sun is acknowledged through a sacred and ancient ceremony by Aboriginal culture ${ }^{14}$. 


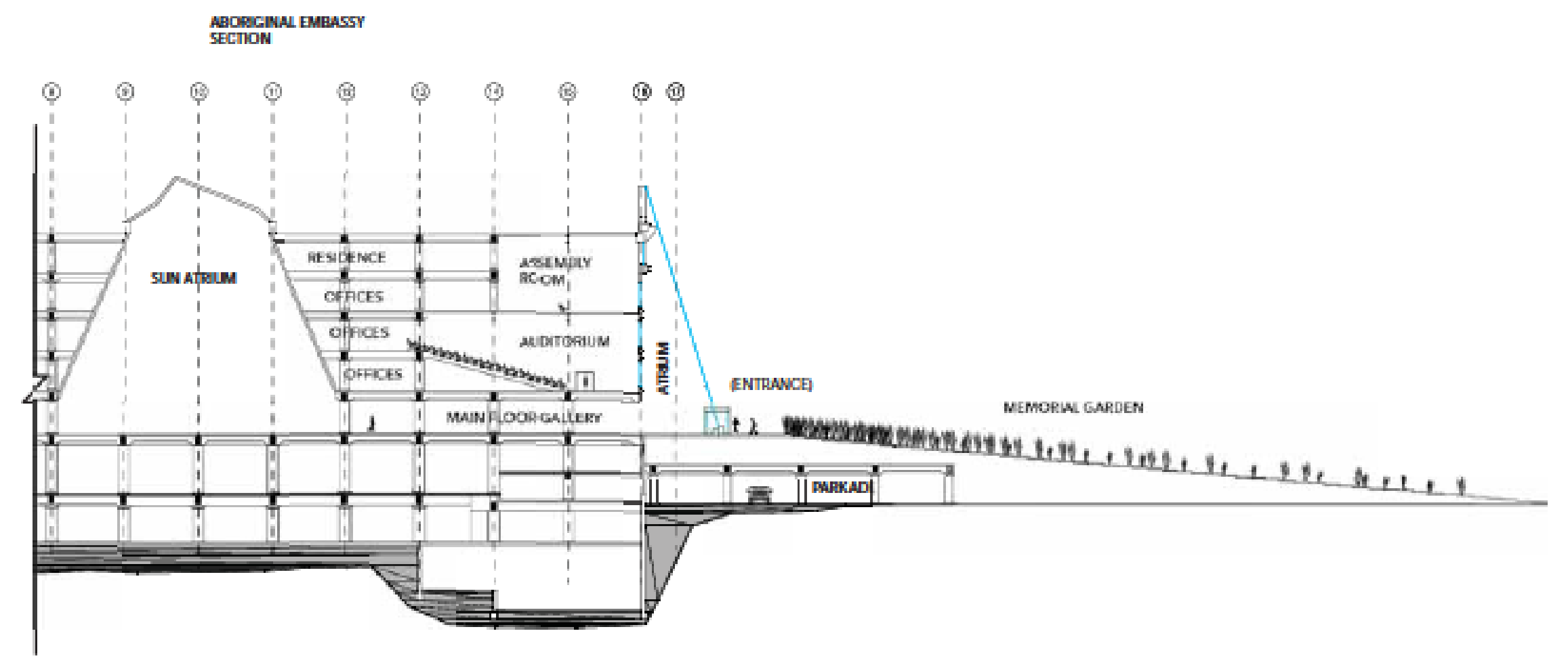

Figure 72.

ABORIGINAL

EMBASSY

SECTION

scale $1 / 32^{\prime \prime}=1^{\prime}-0^{\prime \prime}$ 


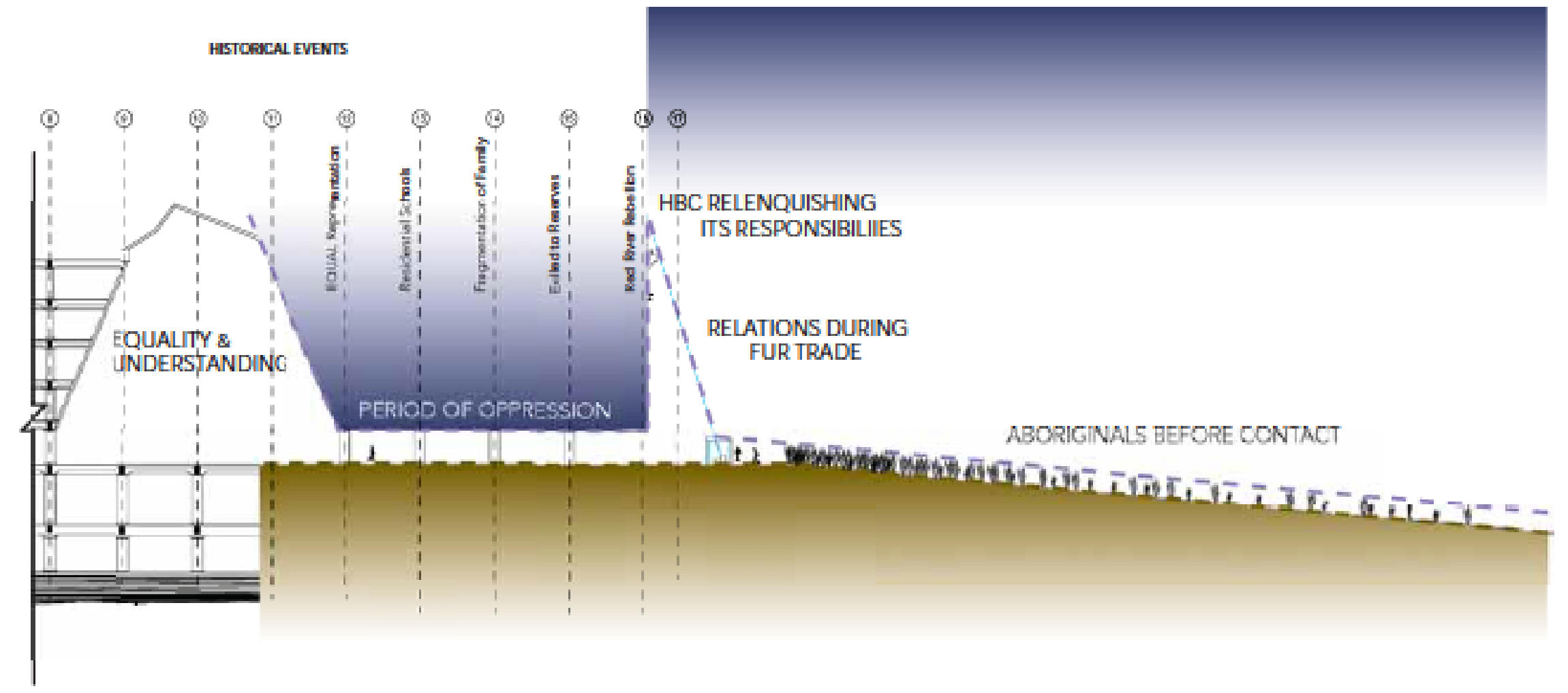

Figure 73.

ABORIGINAL

EMBASSY

REPRESENTATIONAL SECTION

scale $1 / 32^{*}=1^{\prime}-0^{*}$ 
LOBBY/ENTRANCE/ATRIUM 2ND FLOOR PLAN

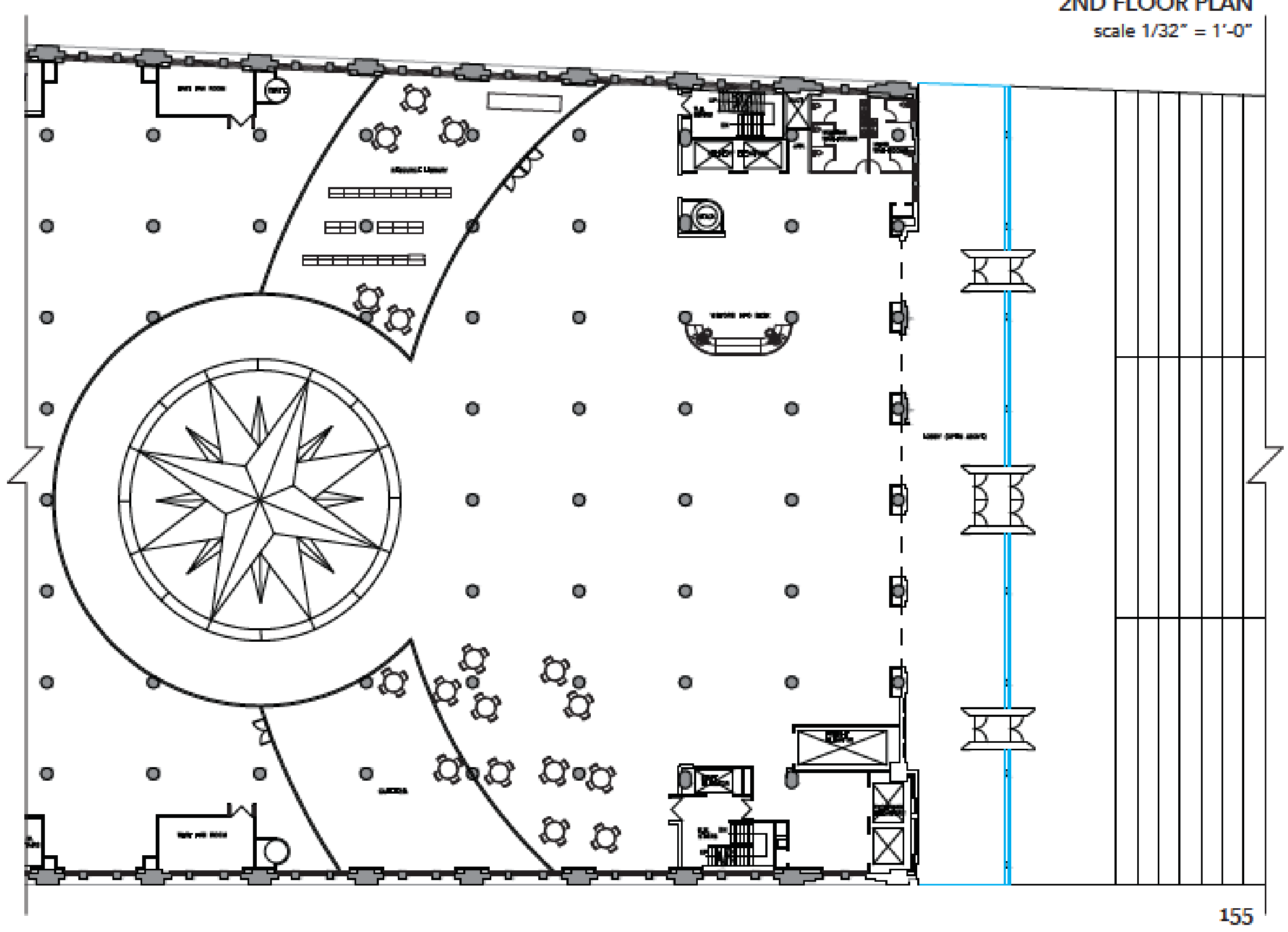




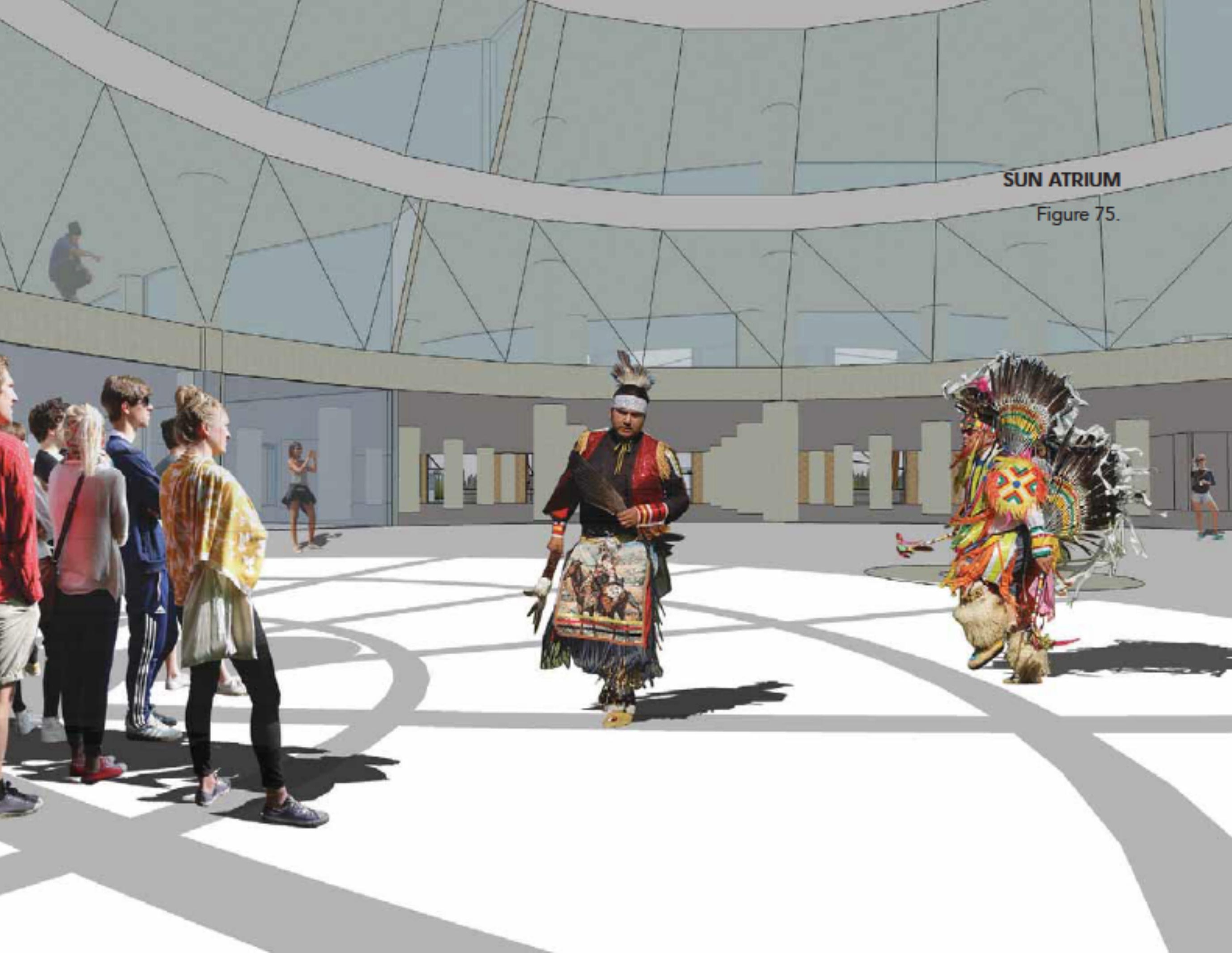


Floor Plans (levels 3, 4, 5, *6)

Floor plans for the building's third to sixth levels are laid out in similar fashions. Curvilinear and radial gestures for the most part act as the main driver for the design of the space, for their intentions/ program. Curvilinear, circular, and radial patterns and shapes are symbolic in Aboriginal cultures and communities for their reference to the Mother Earth, "... all buildings are representative of a woman. They are like our mothers who protect and teach us. We must learn to honour and show respect to the buildings as we would to our mothers"12 The circle is also representative of balance and harmony, the Medicine Wheel, where no one takes higher importance over another individual; thus equality and the significance of having no beginning or end. ${ }^{12}$

Glass wall partitions are used to provide a sense of openness and transparency throughout the building's auditorium, offices, and atrium, but are also used to allow natural light to infiltrate deep within the once dense concrete structure. Circulation is kept to the existing periphery; this allows the open spaces to be kept free and uninterrupted, also allowing the visitor to circulate throughout the building in a journeylike manner, exposing them to all of its spaces wherever possible.

$$
\text { Occupying and using only }
$$

what is deemed necessary - in line with Aboriginal traditional sustainable livelihoods - the building is split in two-halves, the north appropriated for The HBC, and the south for the Aboriginal Embassy. The first floor of the department store remains the same, and its intended use is for The HBC's continued retail operations. Levels two up until six are occupied by the Embassy, with the second level becoming its main entrance from the south. 
ABORIGINAL EMBASSY

EXPLODED AXO - PROGRAM

Figure 76.

Atrium

Auditorium

High Commission

Assembly Room

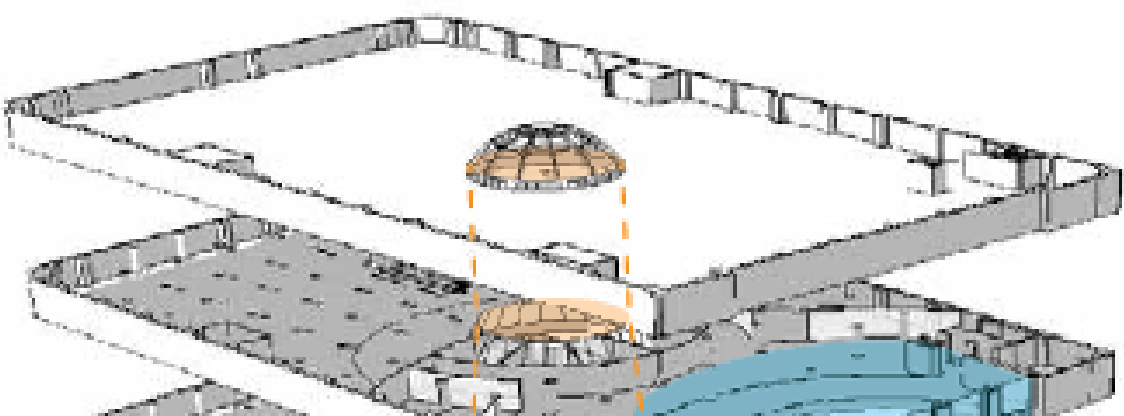

The llow

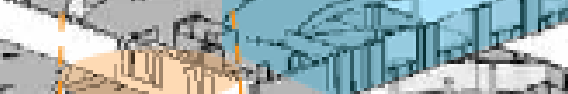

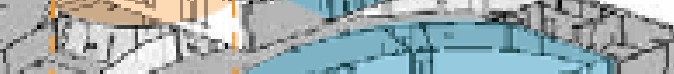

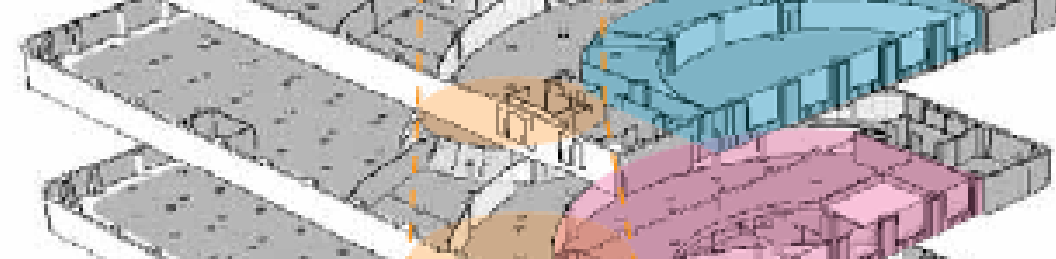

(6) In I)

90 of tor

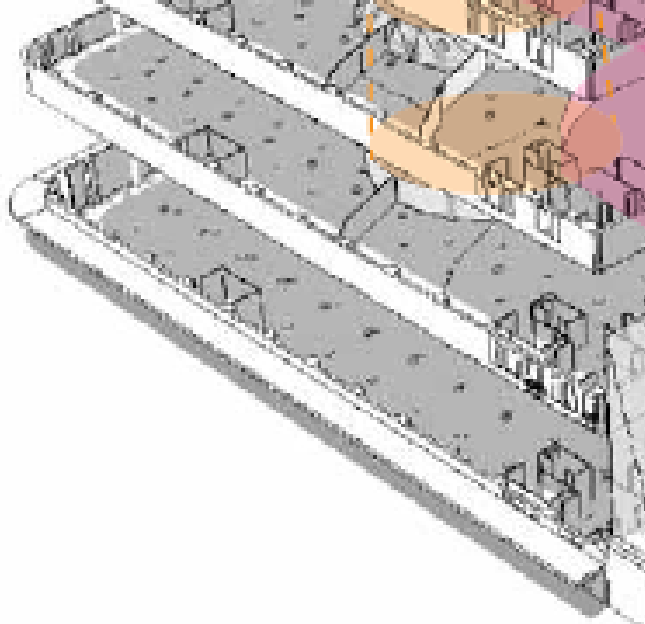

jo.

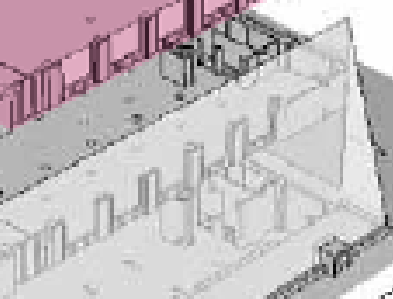




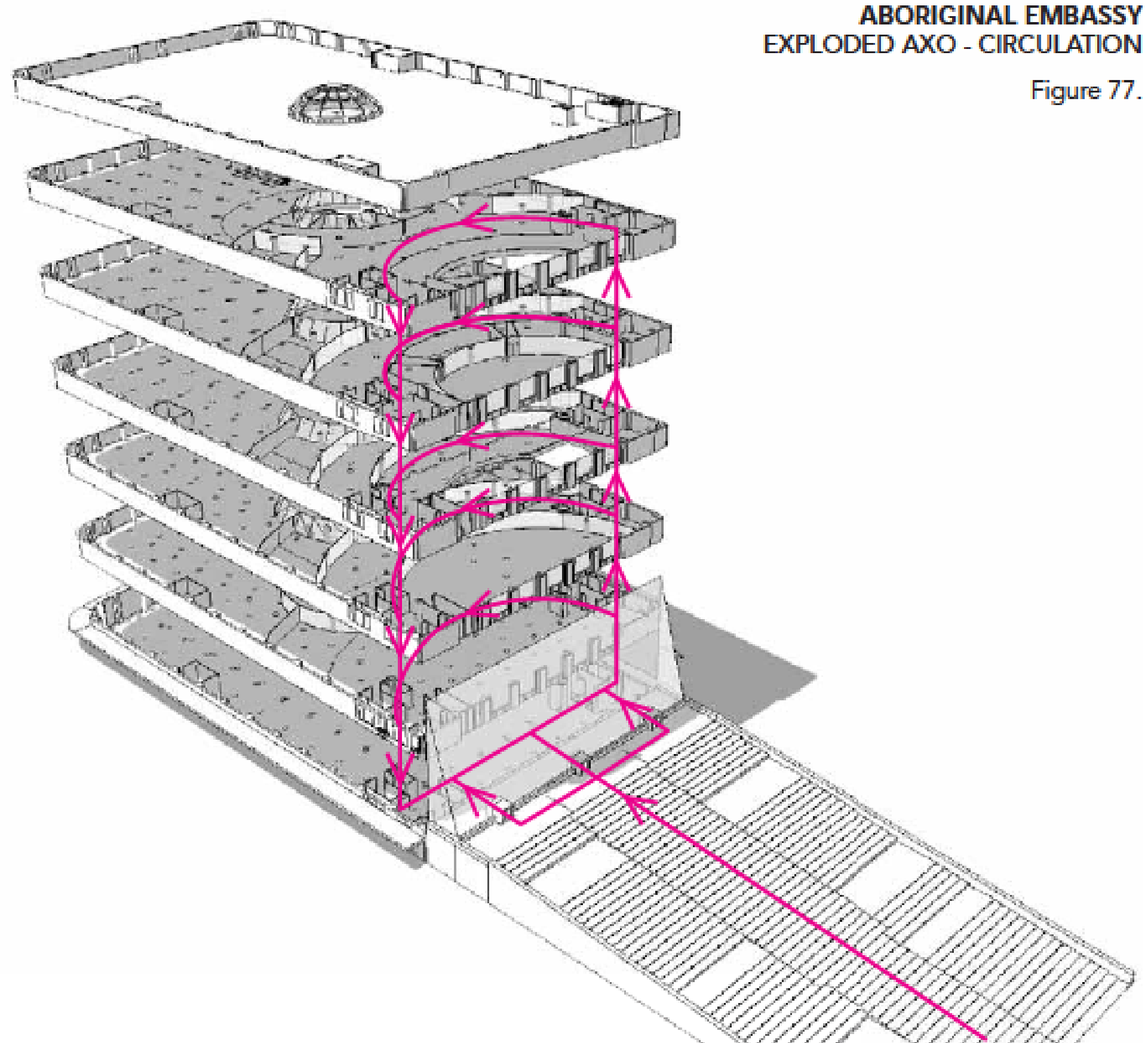


3rd Level

Navigating to the third floor (from the main floor), both public and official visitors are able to gain access to the Embassy's twostorey open auditorium. The circular auditorium of the Embassy refers to ancient Greek theatres with their simple circular design, and ability to accommodate a large audience. "Mathematics played a large role in the construction of these theatres, as their designers had to be able to create acoustics in them such that the actors' voices could be heard throughout the theatre, including the very top row of seats." 9 The ability for the speaker to be heard within the auditorium is of course importantce on its own, but it also lends itself to the emblematic re-establishment of the Aboriginal Voice that was once silenced. The semi-circle design of the auditorium also allows for the symbolic inclusion of the Canadian Government (represented by the Manitoba Legislative Building) in all of its discussions, affairs, and events carried out within the auditorium. Embassy offices are situated around the north side of the circulation corridor, with the auditorium to its south side; the atrium's diameter is 108 feet at this level. 4th Level

The Fourth floor is nearly an exact copy of the Third floor, with the exception of the atrium's diameter, which is reduced to 94 feet (as previously mentioned), and at the south side of the circulation corridor, the second level of the auditorium can be accessed. Again, embassy offices are situated along the north side of the circulation corridor. 
ABORIGINAL EMBASSY

FLOOR PLAN - THIRD LEVEL

scale $1 / 32^{\prime \prime}=1^{\prime}-0^{\circ}$

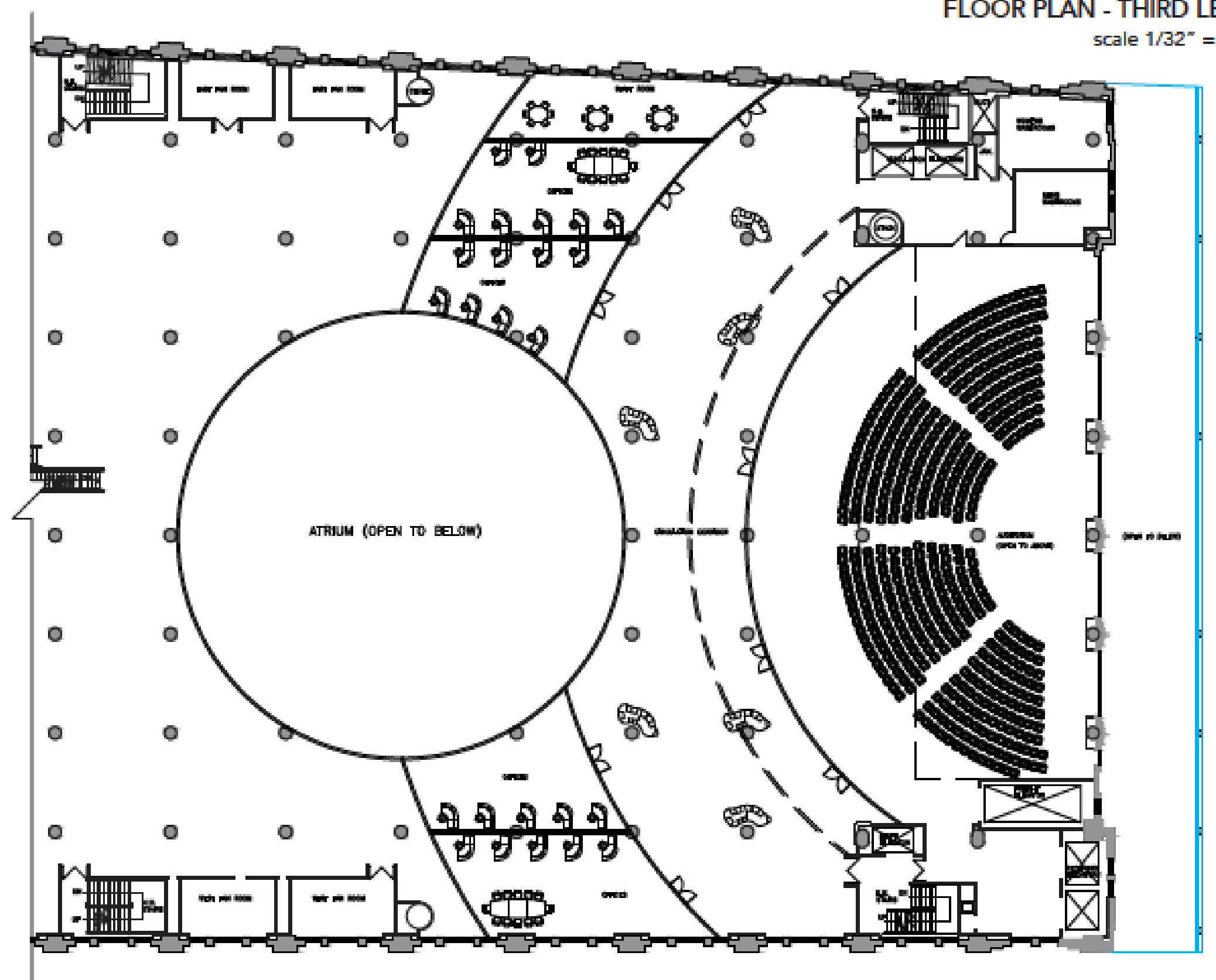


ABORIGINAL EMBASSY

FLOOR PLAN - FOURTH LEVEL

scale $1 / 32^{*}=1^{\prime}-0^{\prime \prime}$

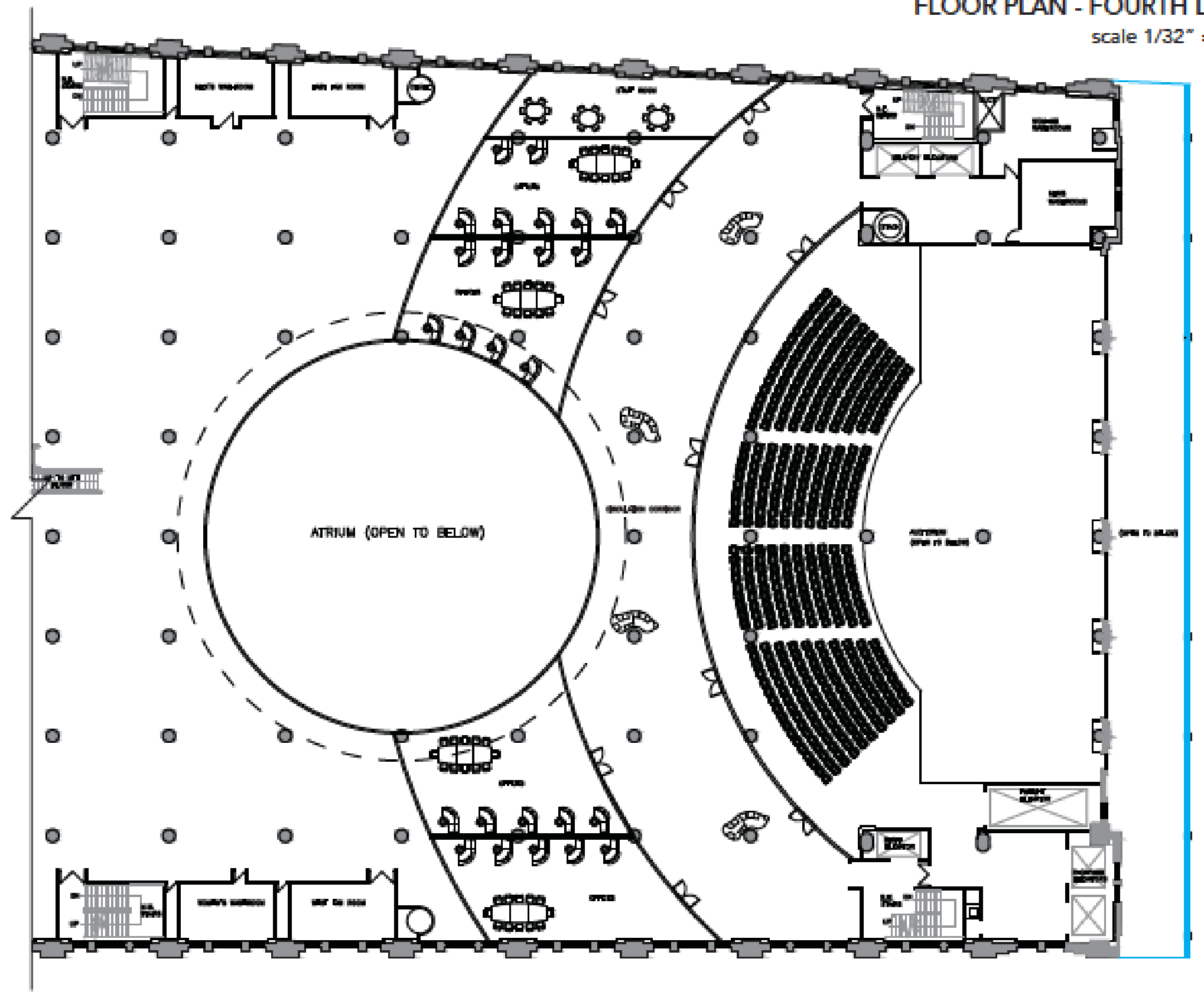


5th Level

Moving up to the Fifth level, public access is very limited, and is mainly reserved for official government bodies, related invited guests, and members of the press. The floor plan is similar again to the Third and Fourth floors, a circulation corridor separates embassy offices to its north, and entrances to the High Commission's Assembly Room is situated at its south. The atrium's diameter here is 80 feet.

The High Commission's
Assembly Room is a two-storey
conference room, primarily used
as the main negotiation space for
governing bodies - the space is

used on scheduled high-occasions, compared to the rest of the building offices which are used daily. Its large open spaces, large horseshoeshaped negotiation table, and large unobstructed views of the Manitoba Legislative Building some 1500 meters south characterize the room overall and prominent design features.

There are two entrances to the High Commission's Assembly Room, each featuring a set of large Aboriginal engraved wooden double doors. Entering these doors, a darker narrow corridor (the Vomitoria) imposes itself on the individual as they navigate their way to its end.
This dim corridor acts as a space for high officials to clear their thoughts and minds before emerging out onto its lighter other side. These main two entrances are reserved only for high official governing bodies, who are also the only persons permitted within the walls of the High Commission's Assembly Room; press, and other media visitors are only permitted within the external press room that overlooks negotiations taking place within.

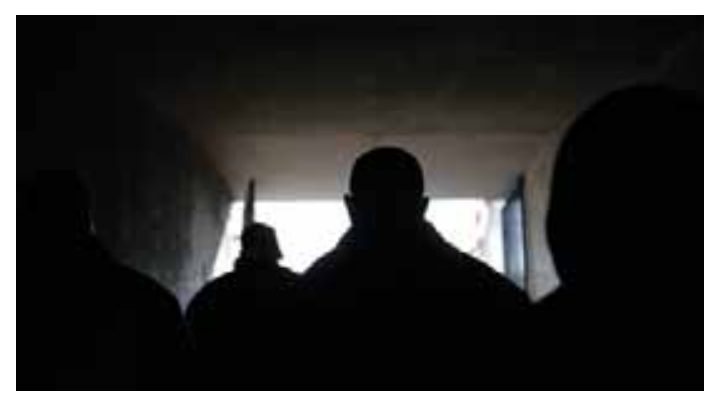


6th Level

The Aboriginal Embassy's

Sixth floor is strictly reserved and accessible by government bodies and officials who are conducting business at the Aboriginal Embassy. The floor also serves as temporary living quarters for officials travelling from outside Winnipeg. Six Living quarters encircle the 68 foot atrium space, giving its occupants a spectacular view down to the second level main floor, but also to the open skylight atrium above. Ample natural light is allowed to enter. Seven additional living suites overlook the High Commission's Assembly Room down below at the Fifth level, making a total of thirteen living spaces; for each of the ten provinces and three territories represented. A Dining Gallery, and Lounge Area are reserved for delegate officials and their invited guests. The circulation corridor serves as a congregation and relaxation space for guests.

\section{$\underline{\text { Rooftop }}$}

A green-rooftop garden is also accessible by official visitors of the Aboriginal Embassy; this may hold various functions and events that are closed to the general public. Here, observers can readily view the abstracted glass form-like teepee structure. 
ABORIGINAL EMBASSY

FLOOR PLAN - FIFTH LEVEL

scale $1 / 32^{\prime \prime}=1^{\prime}-0^{\circ}$

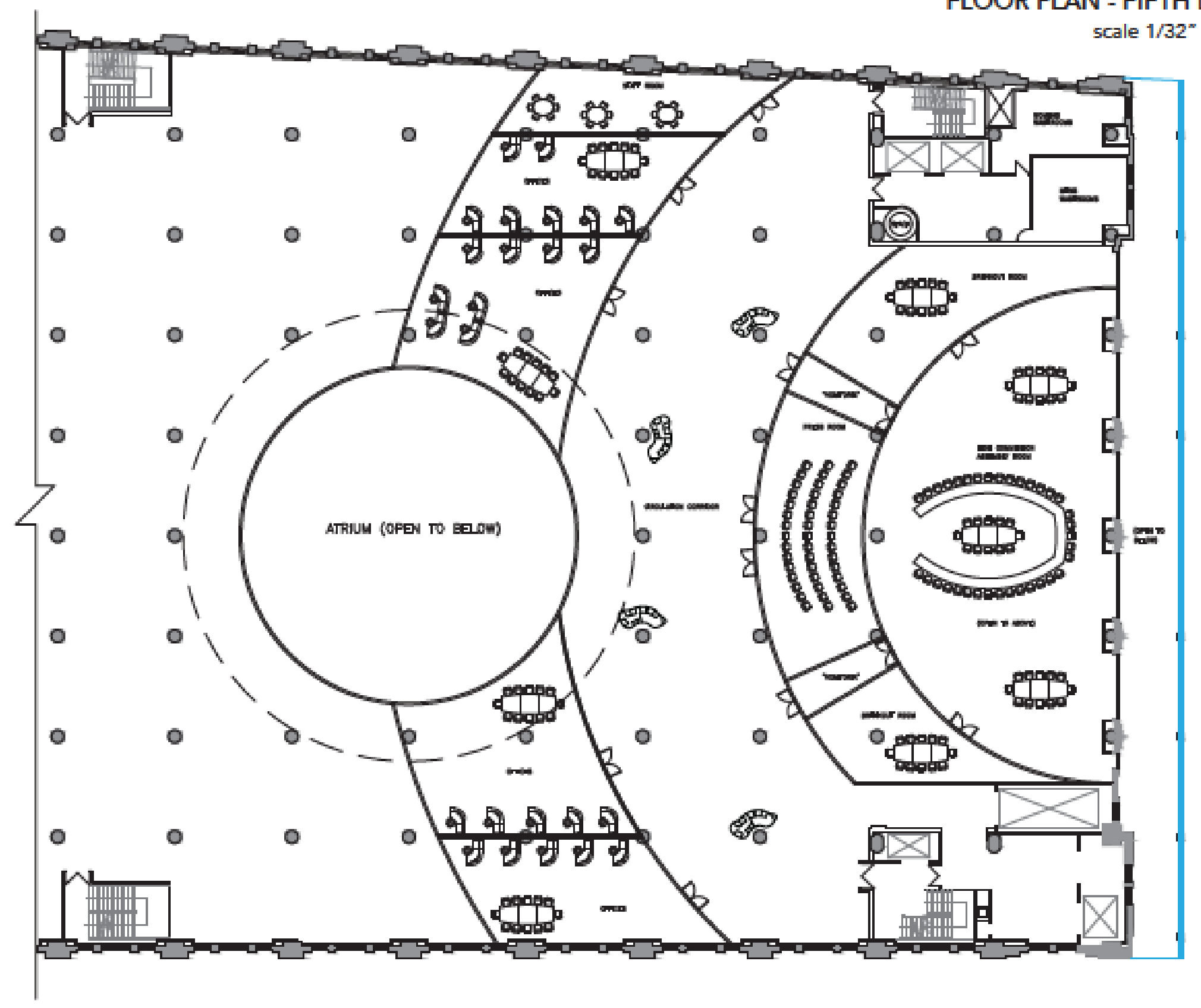


ABORIGINAL EMBASSY

FLOOR PLAN - SIXTH LEVEL

scale $1 / 32^{\prime \prime}=1^{\prime}-0^{\prime \prime}$

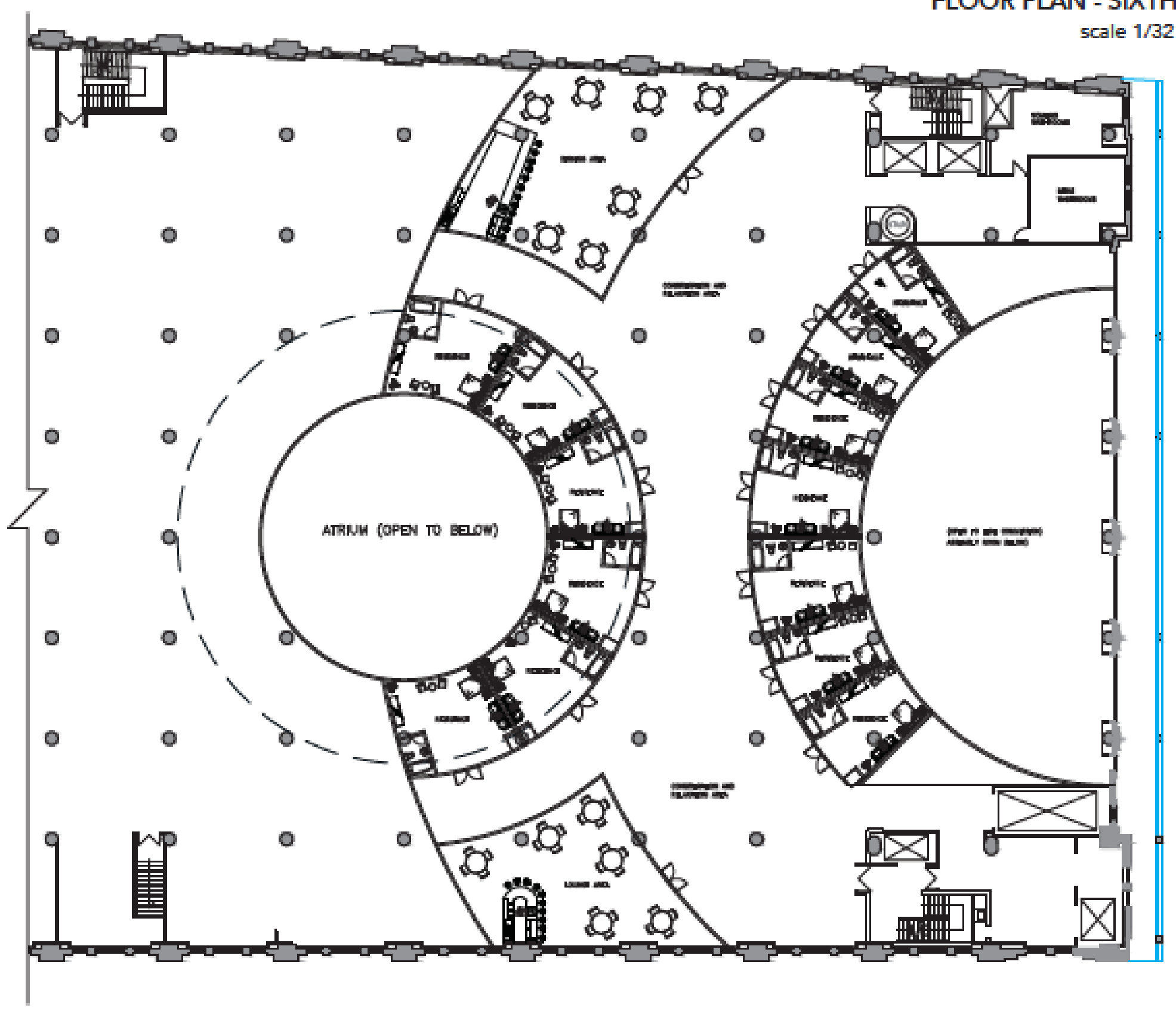




\section{Other Features and Materiality}

The Aboriginal Embassy parkade is located directly below the Memorial Garden. Admitance to the parkade is limited to official use only, and is accessed via Memorial Boulevard, or Vaughan Street. As with any governmental buildings and embassies worldwide, there is a certain level of security that is associated with them. The parkade's concealed location also allows for high profile officials to go directly from vehicle to the Embassy's secure fifth and sixth floors, via underground, avoiding the public or media when needed.

As mentioned earlier, symbolisms are to be kept within a minimalistic palette whenever possible; this includes materiality and colour schemes used throughout the Embassy with the exception of the tiled Aboriginal circular motif located on the ground floor of the atrium. The reduction in colour use will create a sense of openness and lightness.

Materials will be sourced locally whenever possible, to reflect the Canadian Prairie; including Tyndall stone, Birch and Pinewood cladding throughout corridors and offices. Glass is used for the introduction of natural sunlight, which in most instances up to now, many parts of the building have never seen. For the most part, white, cream-coloured Tyndall stone, light coloured-concrete, and wood colours adorn the Embassy - which in turn help reflect any natural light within, helping to reduce the need for artificial light.

There is however the singularity use of red on the building. This is readily evident when observing the building's exterior as the top sixth floor of the department store is highlighted with a red band, encompasses the entire sixth's floor exterior. The use of red serves as a indicator that the building is also being occupied by the Aboriginal Embassy; which may not be apparent 
from the department store's south elevation along Portage Avenue.

As an audacious move, red also serves as reminder of what transpired throughout Aboriginal's contact, partnerships, and colonization between them and Europeans. An Aboriginal individual within the Manitoba Justice System had recounted to me several years ago that in his community, when an individual commits a crime against the community that is of a

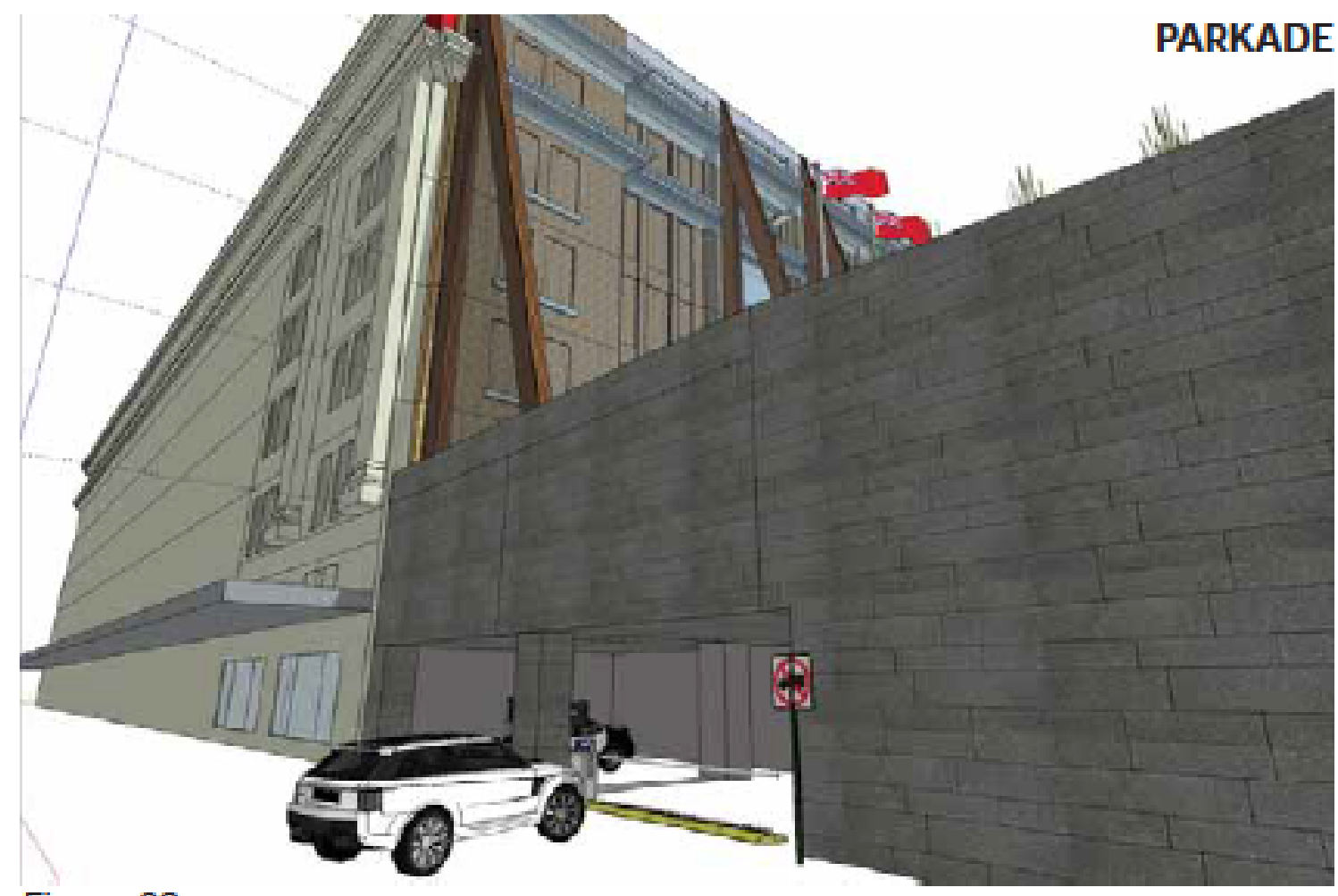
Figure 82. heinous and reprehensible in nature, the community used to mark the individual by skinning a portion of their nose - *Lest we forget. 


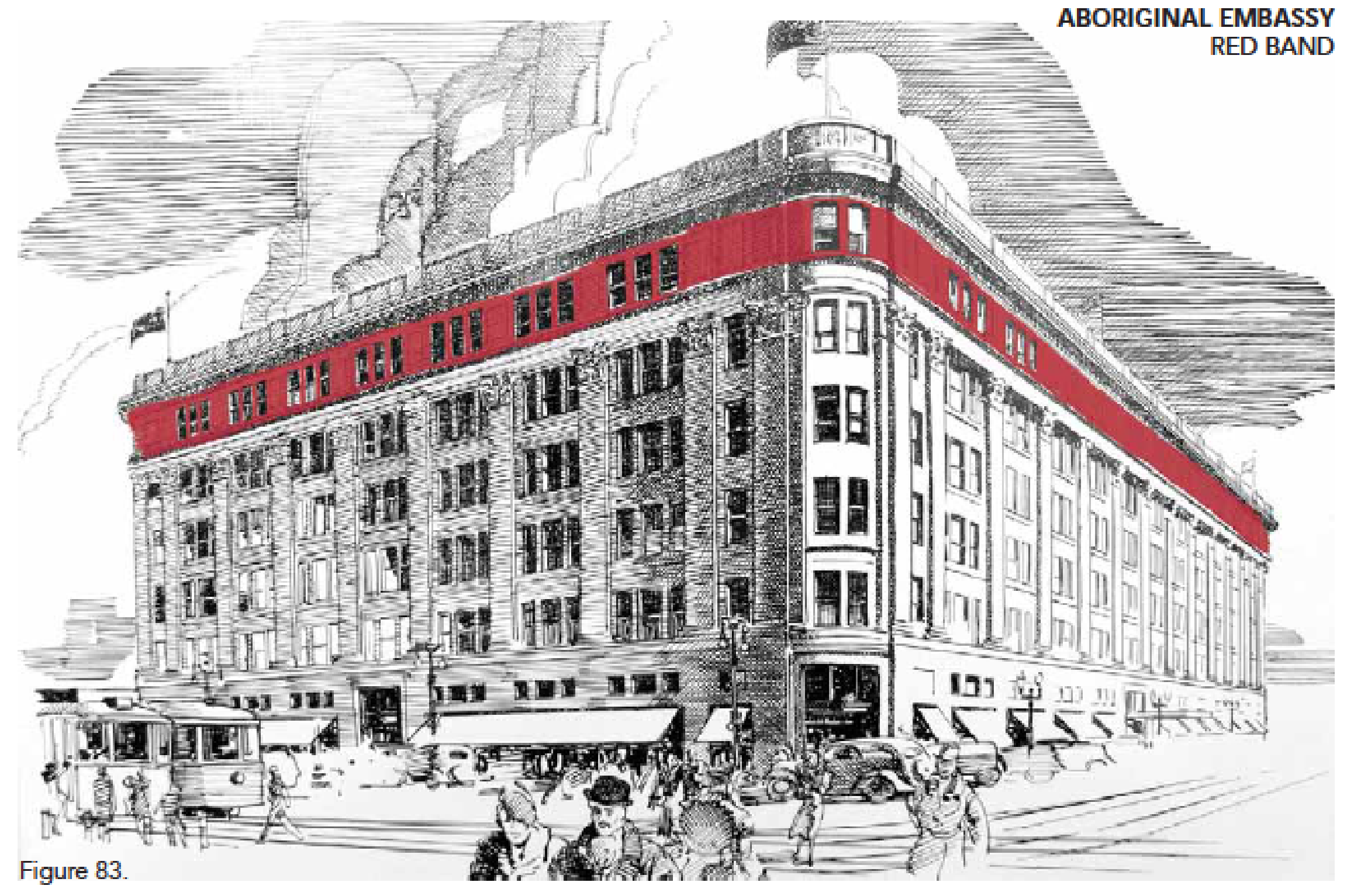




\section{Something Authentic}

Surprisingly, but not pitiful to say, Winnipeg's cultural knowledge of its Aboriginal community is somewhat of a non-priority, even a disinterest for some. Entities like IKEA or Starbucks have had a larger cultural impact on both Winnipegers and Canadians in the last two decades of their arrival, than either the1980 or 1995 Quebec Referendums and their significance on how many of our own French community view our Canadian nation, or the anguish many Aboriginals have had to endure and succumb since The $\mathrm{HBC}$ relinquished its role and responsibilities some 165 -years ago as their employer (now taken up by
The Crown of Canada).

After all, with nearly 1,400 Starbucks ${ }^{15}$ coffee-marts, and $3.5 \%$ of the total IKEA's glorified-warehouses located in Canada (12 of its $361^{16}$ world-wide stores), and millions of satisfied consumers, how could we possibly be wrong?

We are not talking here about branding the Aboriginal people and their culture, like IKEA or Starbucks has done, but something entirely authentic; more than just fulfilling our empathetic wants, but a genuine willingness to learn about another culture, a culture of our own. Architecture in this way can help restore and reinforce an Aboriginal voice, community, and identity; an authentic Canadian identity, making it indeed, A Nation + Store Worth Saving. $\infty$ 
* Lest We Forget: Ode of Rememberance poem.

"The poem honoured the World War I British war dead of that time, and in particular the British Expeditionary Force, which by then already had high casualty rates on the developing Western Front. The poem was published when the Battle of the Marne was foremost in people's minds."

Wikipedia. Ode of Remberance. Accessed Feb. 27, 2015. http://en.wikipedia.org/wiki/

Ode_of_Remembrance

\section{Endnotes.}

01. Posadzki, Alexandra. Winnipeg Free Press. Saks Stores coming to Canada. July 30, 2013. Accessed March 07, 2015 http://www.winnipegfreepress.com/business/saks-stores coming-to-canada-217546621.html

2. National Research Council. The Embassy of the Future: Recommendations for the Design of Future U.S. Embassy Buildings. Washington, DC: National Academy Press. 1986. p.27 03. Gourluck, Russ. Going Downtown: A History of Winnipeg's Portage Avenue. Winnipeg, MB: Great Plains Publications. 2009. p.236

04. National Research Council. The Embassy of the Future: Recommendations for the Design of Future U.S. Embassy Buildings. Washington, DC: National Academy Press. 1986. p.29 05. National Research Council. The Embassy of the Future Recommendations for the Design of Future U.S. Embassy Buildings. Washington, DC: National Academy Press. 1986 p.3106. Turner, Randy. Winnipeg Free Press. Website. City Beautiful: How Architecture Shaped Winnipeg's DNA. Part 1: Great Expectations. Accessed Jan 11, 2015. http://www. winnipegfreepress.com/city-beautiful/City-Beautiful---Part-1. Great-Expectations-273837201.html.

07. Wikipedia Website. Tyndall Stone. Accessed March 03, 2015. http://en.wikipedia.org/wiki/Tyndall_stone

08. Wikipedia Website. Tall Grass Prairie. Accessed March 03 2015. http://en.wikipedia.org/wiki/Tallgrass_prairie

09. Wikipedia Website. Theatre of Ancient Greece. Accessed

March 11, 2015. http://en.wikipedia.org/wiki/Theatre_of ancient_Greece

10. Ray, Arthur, J. Jim Miller. Frank Tough. Bounty and Benevolence: A History of Saskatchewan Treaties. Montreal, OC: McGill-Queen's University Press. 2000 p.4

11. Ibid. p.58

12. University of Manitba. Aboriginal Student Centre. Migizi Agamik (Bald Eagle Lodge). Aboriginal House: Join the Circle. PDF Electronic Brochure. p. 7. Accessed Feb. 24, 2015. http:// umanitoba.ca/student/asc/aboriginal_house.html

13. Tourism Winnipeg. Weather in Winnipeg. Accessed Mar. 01 2015. http://www.tourismwinnipeg.com/visitors/weather

14. Quinlan, Mark. CBC News. Sunrise Ceremony Marks National Aboriginal Day: Aboriginal Sunrise Ceremony is One of the Oldest Traditions of First Nations Culture. Accessed Feb.
26, 2015. http://www.cbc.ca/news/canada/sunrise-ceremony marks-national-aboriginal-day-1.1245747

15. Babad, Michael. The Globe and Mail. website. How Starbucks Has Conquered Canada. May 27, 2014. Access Feb. 21, 2015. http://www.theglobeandmail.com/report-onbusiness/top-business-stories/how-starbucks-has-conqueredcanada/article $18865907 /$

16. IKEA website. IKEA Retailing Facts and Figures: For Business Year 2014. Accessed Feb. 21, 2015. http://franchisor.inter-ikea. com/Whoweare/Pages/IKEA-retailing-facts-and-figures.aspx 

APPENDIX 174

POST-SCRIPT 205

BIBLIOGRAPHY 210 
APPENDIX 1 Interview with Manitoba Treaty Commissioner James Wilson

Conversations with the

Commissioner:

Complete Transcript

Part 1
- along with Office Researcher Darren Courchene

Thursday December 18, 2014. 1340hrs.

Length: 00:12:05 (hh/mm/ss)

Treaty Relations Commission of Manitoba Office 400 - 175 Hargrave Avenue. Winnipeg, MB.

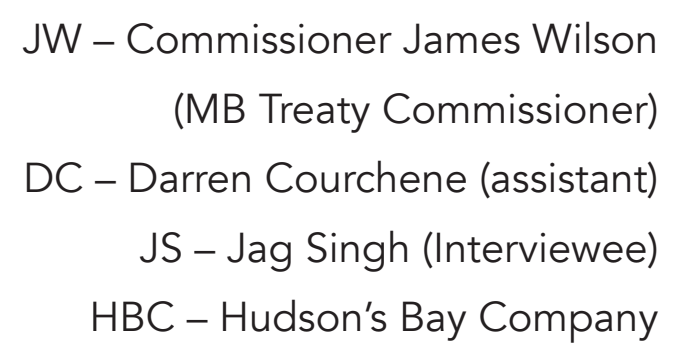

JW: I asked Darren to be here. Darren is a researcher with our office. Really really strong background in both the written record on treaty and in oral history on treaties. So whenever I have questions, problems, I'm always texting Darren.

DC: Usually takes me about half hour to respond to one main question.

JS: That's pretty convenient to have actually. I wish I had that resource. It's like having Google.

DC: He calls me Wiki.

JW: Wiki on Treaties.

JS: So I'll ask some of the questions and we'll go from there. So I guess, what is your affiliation or relation with the Aboriginal community?

JW: Well, our organize... I am Aboriginal I guess that is the first 
part from Opaskwayak Cree Nation in Northern Manitoba. My mother, my mom is Scottish, my dad is Cree, so I think I grew up on the reserve, I shouldn't say I think I grew up both on the reserve, I grew up both on the reserve and in the states. Kind of in mainstream both, mainstream on the reserve. Our organization's role and my role today is basically as a facilitator or mediator in the treaty relationships. So, working with First Nations and the Federal Government, Provincial Government, businesses to try to rebuild the relationship. Rebuild the treaty relationship.

JS: So what do you feel the primary concerns of Aboriginal today both Winnipeg, and Canada? In relations to treaties do you think it's a lack of knowing what the treaties are?

\section{2:10}

JW: I think its Equity. I think as people understand the treaties more, they understand what the relationships should look like, and they understand that there's huge opportunities to work together, and that it was about a partnership. (quote used ch.7)

JS: Yeah, cause I think a lot of times people, for me anyways the public often see the treaties as a one sided thing. A lot has to do with the media, what you are shown on TV.

JW: yeah.

JS: Before I did any of this research,
I was very I guess biased, as many people, afraid to say are. Very biased on what the treaties were. It was a one-sided affair that Aboriginals were trying to gain something, or, it wasn't supposed to be like a dialogue l'd like to say, right, if I can say that? A treaty is suppose to be a dialogue, of how they can work together, the building of a relationship.

\section{3:10}

JW: Right. So I think people see what the relationship should of looked like, and they see what could be, and they see how things are today. And they see huge inequity today in education, health, economically, so people want, they want to change things. They want things to be different than they 
are now. For some people that means cash, employment, for some people that means having a voice, they feel voiceless, powerless. But I think it has to do with this equity issue.

JS: What do you think Aboriginal peoples views on the Hudson's Bay Company today? Or is there an opinion they have?

JW: I think it's mixed. Like up north, in my community there's a lot of people who have a strong understanding of the history.

JS: Sorry what community is that?

JW: Opaskwayak Cree Nation. And the Trappers knew that they were the players, they were the business brokers, the HBC relied on them, not the other way around.

JS: What I read is often the reverse, that Aboriginals relied on them [HBC].

\section{$04: 45$}

JW: Yeah. No. it's a perspective, having First Nations people having agency. That were not just sitting around hungry, homeless, and then the fur trader shows up gives us trinkets, "oh yay".

JS: That's often what you read, its obviously from the source you're reading it from. I was reading a book by the HBC, from the HBC. That's exactly how its portrayed.
JW: So I think it's a bit mixed. Trappers would view the relationship differently, think academics would view, or some academics would view HBC as this colonial oppressive regime, big business, big corporation.

What do you think of that? [directed to Darren Courchene]

DC: The only example I can think of back home, when we did have HBC forts for a while, then eventually store. People would always go to it, and they would sell their furs. People who were still trappers they would sell their furs there, they would make a modest living during the winter. During the summer, they would go hunting, or helping other farmers, or their own farms. They would see it as 
a supplemental income, not as their sole income. They would see it as place where they could do what they do.

JS: That's today?

DC: With the store, they would go, and they would have credit, they would utilize it, it was a good relationship. But when they store went away, they would think "now we have to go to the city".

JS: So do you think the relationships that's today so you think are positive ones, negative, or neutral ones?

$06: 40$

JW: My impression is that as people understand our history better, they understand our agency better, and our history. And we are not just pawns of history any more. We're, we shaped the history of this country. I don't view it as a negative history, I'm sure there's some power imbalances and stuff like that, we were, and continue to be major players in Canada. Perhaps, it's a bit of a political spin, maybe a bit of revision of history, but that's how I view it. First Nations have always had agency, always been in the driver's seat. Lot of really strong businessmen in dealing with the $\mathrm{HBC}$, so we helped create what it is. I don't know if HBC would recognize that, maybe some of their archivists would, or some of their historians would.
DC: You have to look at where they are right now. The store will be closing and become Saks Fifth Avenue in Winnipeg.

JS: Is that what they think will happen to the store?

DC: No, it is what going to happen in 2016.

JW: The whole thing, or just parts of it?

DC: The main floor, the second floor, and the basement will be Saks, and the rest of it will just be office building. They're loosing their foothold.

JS: I heard rumours that they wanted 
to unload the building to the government as a tax break, and just lease it back type of thing.

JW: They tried to sell it to the $U$ of W [University of Winnipeg] for \$1, but they couldn't come up with a good plan of the space.

So, HBC owns Saks?

JS: Yeah. They recently acquired them this last year. I think that they've gone away from the lower end like Zellers, got rid of Zellers, and have going for the higher end to become a global retailer empire now.

JW: I had the opportunity when I first started my job to go to York Factory, which is one the first $\mathrm{HBC}$ trading posts. And Richard Baker flew up there in a helicopter, president and governor or something like that,

DC: He still holds that legal title?

JW: Yeah, and he was the first governor of the HBC to be at York Factory since like 1905 or something crazy like that. We went and toured around the building with him, it was pretty cool. It was neat to be with him, cause he had just acquired the company probably the year before, was quit recent, probably around summer 2010, or 2011. Not sure when they bought HBC, he's American.

JS: There head office is in the states, well in Toronto, but they're an
American company now.

JW: They had a scale there, in the big building [the factory]. I guess scales were really, really rare, so people would go weigh themselves, and write their name and weight. There's one window-sill there that would have "Mr. and Mrs. Simpson" with their weight on there. All these historic people that went in, so he [Richard Baker] went and did it, and they let him write on there.

JS: There must be a big gap between early 20th century, to now?

JW: [laughs] Yeah. He's a pretty interesting guy, they bought, like you were saying, Zellers was part of it, so 
they bought, I can't remember how much they paid for everything and turned around and sold Zellers to Target for the price that they paid for the whole deal basically.

DC: Sounds like a pretty smart businessman.

JW: They had a reception here at the Museum [Manitoba Museum] at the Nonsuch, and they went through, cause they have all the archives and stuff. They got the old governor's chair, so he sat down there, got pictures take.

DC: Have you [Jag Singh] gone to the $\mathrm{HBC}$ Archives here?

JS: I have. I actually came back in
September, and spent a week there just going though photos, and blueprints. There's like 900 drawings, and drawings, maps, and what not that they have. Originals on vellum, animal skin, really interesting. I don't know if you have seen it. If you have the chance, make an appointment, and see some of the stuff. Some of the stuff in the vault, that doesn't ever come out on display.

DC: Did you actually see the original Charter?

JS: Uhmm. I saw one, not sure which one you're referring to.

DC: There's one that you actually have to go into the vault, it's all framed and it's glass, it's like "wow", you can't even touch it. You see the actual Charter.

JS: Oh, the Charter. I think they've actually moved it. When did you see this?

DC: This was way back. 
APPENDIX 2 Interview with Manitoba Treaty Commissioner James Wilson

Conversations with the

Commissioner:

Complete Transcript

Part 2
- along with Office Researcher Darren Courchene

Thursday December 18, 2014. 1340hrs.

Length: 00:20:00 (hh/mm/ss)

Treaty Relations Commission of Manitoba Office 400 - 175 Hargrave Avenue. Winnipeg, MB.

$$
\begin{array}{r}
\text { JW - Commissioner James Wilson } \\
\text { (MB Treaty Commissioner) } \\
\text { DC - Darren Courchene (assistant) } \\
\text { JS - Jag Singh (Interviewee) } \\
\text { HBC - Hudson's Bay Company }
\end{array}
$$

DC: ... they open the lid, you can just smell how old that thing was. It's a really strong smell.

JS: It [Charter] must be in a fireproof glass.

DC: You can tell the lettering was beginning to fade.

JW: So to go back to your question, I think that there's a shift in thinking, amongst academics, elders from this, thinking that, used to be, used to view us historically being ripped off in relationships. Either through the Treaties, or through other relationships.

JS: It would always portray them as victims - victimized, not as...

JW: Now that shifting to an interpretation of the treaties, interpretation of business relationships, like HBC, as one where 
we're equals at the table. We have the savvy to be there, we had the education to be there. It may not have been western education, but we had strong negotiating skills, we were there as equals. And these partnerships we had, whether they were negotiated through treaties or through business, were strongly negotiated as equals, right? And that's a quit modern shift in the last 10 years, or so.

DC: But, even in the stories that elders would share with us, they would have big trading ceremonies, they were the ones that would actually set the protocol in the treaty process, the HBC would. You had to follow the $\mathrm{HBC}$ protocol in order to enter into treaty with people.

JW: And there was a point when First Nations asked HBC people to be at the treaty negotiations. Because they said, these guys know how to do business with us, so we want them here to show you the Crown, how to work with us. Because, you were saying, Jean Friesen always talks about this, it wasn't just, here's our pelts, here's your trinkets, and we trade. It was gift exchange, pipe ceremony, medicine chest given over. Sometimes protocol lasting days before they would actually get into trading.

\section{JS: That's interesting.}

JW: That's informed treating negotiations.

DC: HBC also issued a bunch of calendars where they actually showed the relationships. And one of them actually shows the trading ceremony and the European holding the pipe. The story behind that is, the First Nation people commissioned the pipe to be made in order to formalize that relationship and trading partnership. The Europeans, and HBC had to take care of that pipe, and only when they got back together was that pipe ever pulled out, displayed, utilized to reformalize that partnership. So they had to take, be in Rome, "When in Rome, do as Romans do", so they had to follow traditional protocol when 
entering into relationships here.

JW: You better get him [Darren Courchene] to fill out a form [Ethics Consent form], (laughter), cause now you're doing a focus group.

JS: I will definitely have to add your name to this.

What is your professional and personal views of Aboriginal Oral Culture and its traditions and I guess its role it plays?

JW: Significant. Very Significant. Because in culture where there's a strong oral history, it wasn't just done, oral histories weren't done nonchalantly. I'll give you and example would be like my grandfather Cree, he was a storyteller. It was an informal title, but it was a kind of a title almost.

And he had these legends he would tell - and I never really knew this stuff as a kid, he would just always tell stories - and he had some stories he would tell, and they were quit long, but there would be big chunks missing, right.

One was of this guy named Wameesusus, he rode in a canoe, he could bang on his canoe, and it would drive itself, he was kind of like a supernatural sort of dude. He tells this story, then there's this huge gap in the story, and it goes onto something else. And I remember going, "why is there this big gap in the story, why can't you just fill it in, or something?" And it was my dad who explained to me, that he could only tell that story exactly how he heard it. So, verbatim, he could only tell that story exactly how he heard it. So that story, my dad figures that story is probably thousands of years old. So over time, somebody along the line forgot a chunk, or left a chunk out. And you can't put that back in. It's that story now.

JS: It's really interesting actually. It's keeping it authentic, right?

JW: So even though it has that huge gap that doesn't make sense, that's the only way he can tell it, because that's exactly how he heard it, and that's how his dad heard it, or whatever. 
JS: Cause if you were to fill that in, how would you be able to determine the authentic, original from, what you've put in there. It's not like a building, where you have a historic building, that's a big thing in heritage, where you want to be able to differentiate the old and the new. You don't want to replicate the past, you want to differentiate, so that way there's an honesty there. This is the past, this is what's there, even if you want to fill in that gap, you should be doing it with new materials, new techniques, to show that

DC: Instead of pretending that,

JS: Exactly, pretending that this has always been there, but in fact it was removed for whatever reasons, for war, or what not. Big thing in heritage restoration is that the honesty, the authenticness.

DC: You also have to remember, think of oral history of like a jigsaw puzzle. Jamie has one piece, I have one piece, you have one piece. And were trying to fill out this one corner. I'm not going to have all the same history as Jamie, and Jamie isn't going to have the same history as you. So all of us come together, sit down, and remind each other what that history is. Like that story of the canoe, I think I know part of that story, my great uncle would tell that story of one individual, and that one canoe was alive, and he eventually uses that canoe to take his grandmother back up to the stars, and that the end of the story, when he leaves with his grandmother. There's pieces and chunks.

JS: There's a dialogue, right? Feeding off one another.

JW: ... But really disciplined. And that's one of the mainstream criticisms of Oral histories is that you could say anything, to justify whatever, there's such discipline involved. We have a series of books, oral history books, there's an elder he shares a story of his grandmother gathering her grandkids around, and she told them a story every night, every night for forty-nights, it was in the winter, and on the fortieth night she gathered 
them around and didn't say anything, the kids were telling her to continue the story, she said "No. What did I tell you on day one?" They said they I don't remember, it was a long time ago. She said "I'm not continuing the story until you tell me everything from day 1 , day 2 , day 3 , day 4 . There's a real strong discipline involved. And those guys that | told the "canoe story", they carried that, I don't know what that proper term was, my dad called it "Regalness" they carried that, they just had something about them that you knew these guys knew a lot, and didn't make shit up.

DC: Going back to that, one of the things that he taught me when I interviewed him for my thesis, he says "You have no right to change anything, that's the Golden Rule amongst when you are doing Oral history." You cannot change anything, doesn't matter how vicious and ugly it is, you have to let that truth stand on its own.

JS: Right. It's no different, it should be no different than if you write it. If you're writing something, you want to write it as it is, or as it was. Just as if you were dictating it or saying it.

*10:07

How does the Oral tradition play into Treaties, what are the roles?

JW: So now the Supreme Court, for years it didn't play a role, in the mainstreams it didn't play a role. For
First Nations it always played a role, Oral Histories were paramount. There are stories always in the communities of what was talked about, what the promises were. Sometimes they had little to do with what was on paper, it was kind of the mainstream dialogue, but now the Supreme Court has told us, informed us I guess, that Oral Histories are to be given equal weight as the written text.

JS: That's just recently right? 96?

JW: That now, both the Government opens a can of worms, they've always said, the written dialogue is paramount.

JS: Which is a European type of, of 
how Europeans record their history through paper.

JW: And for First Nations, we've always told you that this has been important. Now you have this clash of cultures, and clash worldviews happening. There's a dialogue happening now with the Federal Court justices are now having a dialogue with Elders across Canada, about basically trying to figure out how to bring oral histories and testimonies into an adversarial courtroom. Elders that are held in esteem, about certain protocols about interrupting, how do you bring that into a courtroom where their job is to cross-examine you and ask challenging questions, be confrontational. How do you meld those two? Cause the Supreme Court is saying that we have to, Elders are saying, "We want to have a voice" at the same time they just get attacked. It's a real, it's difficult for Elders. The legal system is trying to figure it out.

JS: Re-appropriating itself.

JW: Yeah, and the real practicalities.

DC: Yeah. You have to remember that all cultures started off as oral cultures, they forgotten it, its quit the amnesia, but they weren't always writers. Even the Europeans didn't have writing until it was introduced by the Chinese.

JS: Right. Cause the printing press wasn't always there.
DC: The first one to develop writing and record their history was the Chinese, it wasn't until they started doing that exchange. And with respect how oral history fits into treaties. Only example I can give is that at the time of Treaty number 1, the negotiators, the First Nation negotiators said "Okay, we got to record this in our histories", and they selected 7 children to listen to the negotiations. And every year those 7 children would get back together and recount the story of treaties. And that way they could remind each other of any gap they forgot. That carried down to this one Elder in Rosa River, his name is Oliver Nelson, and he is one of the carriers of that knowledge now He shared that with 
a group of us when I was working at the Treaty 1 Protection Office, this is the story of Treaty. There was a lot more discussed and negotiated than the written record and that has actually made it into the text. Oral history has a lot more detail that the written record.

JS: I can imagine. A poor example is when you are texting, than when you are doing a phone conversation. How much is lost in translation there when you are just writing things out, as opposed to having a dialogue faceto-face, or over the phone.

JW: It's a good analogy, I like that.

JS: How much information is just given, just through that one minute. One minute of texting versus one minute of conversation, there is just way more to be said.

DW: Well have you ever gotten into an argument with your partner? "What do you mean?" It's a long drawn out, five-hour, the inflection of your tone, is taken totally out of context.

JW: And if you try to be sarcastic, it doesn't work. (laughs)

DC: You also have to point out that Indigenous people weren't just strictly oral people too, we had our own literature.

JW: It wasn't Roman lithography.
DC: It wasn't like letters on a page, what we would do is draw symbols, it would be almost be like Egyptian Hieroglyphs. Another form of literature was the stars as well, the constellations. We have a name for every constellation, and there's a story attached to it relates to how you are as a people. There's also the painted Tomahawks, everyone thinks they were used for war, but no. The story started with a "zombie", it's the only way I could think of it in a modern day context, and how he killed his brothers, cause he wanted their wives. And the only way to get back was to do something good for the people, he provided them with how to write something on, their histories on, their transgressions on 
something.

*16:20

JS: Is the Oral Culture the most strongest one in forms of communication for?... I guess not to put hierarchy on things.

JW: I think so, there's a Huron academic named George Seewee, have you ever read his book (towards Darrell Courchene) name American Huron History? His thesis is that oral cultures have a higher level of, he would say thinking, that they are more advanced.

DC: There is a higher order of things. There are four layers to our language, whereas European languages it is all about commerce, and Indigenous language, specifically Ojibiway, you have everyday common language, you have prayer language, ceremony language, and you have spirit language, and all four of those interact, develop complexity.

JS: Different layers.

DC: He also explained that about stories too. There are multiple layers in stories. There stories you give to children, there are stories you give to adolescents, stories you give to adults, stories you give to Elders. At the Elder level, you should know all those other three levels, you should understand. It becomes more philosophical at that, and then it makes story entertainment.

JS: I will have to look more into that.

DC: I wrote an entire thesis on Oral history. Did we cover too much of your subject? (laughter)

\section{*18:15}

JS: No. There's never too much. It's great. I guess one of the questions I had here was "How does the loss of language contribute to loss of Identity?"

JW: I think it does. I think that's why there's such a strong push now to start immersion programs. So I'm 46, I would say that 50 years-old 
and younger, in my reserve, very few people speak Cree. 50 and older, they all speak Cree, especially as you get older, more and more people speak Cree. There's not anyone who just speaks Cree, everyone 50 and up speaks English and Cree. And there's a few people 70s and 80s that speak, what my dad would call a "higher Cree". 50 and younger don't speak Cree, but now there's kids going through the school system that are starting to speak Cree, so probably up to grade 6 . Kindergarten to grade 6.

JS: They teach that here in Winnipeg?

JW: They're trying to. They're trying to.
JS: Because I went to French Immersion growing up as a kid over in Transcona.

DC: Well the French language is protected under the constitution, so they have to provide that.

JS: That's another thing that I wondered was how come there was no, there's English and there's French as National languages, how come there is not an Aboriginal one like Cree or Ojibiway?

JW: Good question.

JS: Why isn't that part of it? You have your... Cree?
DC: But if you go to the north like Nunavut, they have Innukatuk as one of their official languages, and its spoken... 
APPENDIX 3 Interview with Manitoba Treaty Commissioner James Wilson

Conversations with the

Commissioner:

Complete Transcript

Part 3
- along with Office Researcher Darren Courchene

Thursday December 18, 2014. 1340hrs.

Length: 00:19:03 (hh/mm/ss)

Treaty Relations Commission of Manitoba Office 400 - 175 Hargrave Avenue. Winnipeg, MB.

DC: ... and they're the only ones in Canada that do that, and they provide funding, equal funding, for each.

JS: Really?

DC: Everyone else in the provinces is like "No, don't".

\section{$0: 15$}

JW: So, I think that its recognized that culture is attached to language... And there is people trying to revive the language. How successful it is, is a different question I think.

DC: When you lose language, or language is taken away, or it's left at the wayside, you don't remember the understanding of who you are. Like, for Anishinaabe people, it's a contraction. Anishinaabe, originally it was, "(something in Anishinaabemowin)" meaning, "A human was lowered on to the earth". And so what you're saying is that the creator put you in 
a very certain place. And it tells you that identity. But then you also have a sub identity of Ojibwe meaning, "(something in Anishinaabemowin or an Ojibwe dialect)" or something like that, and it means, "We survived the flood by going into the mountains." So it talks about the great flood that every culture has in their stories. And how we survived the flood was by going through the mountains. So we call Anishinaabe-Ojibwe the human being that was lowered onto the earth but survived the flood by going through the mountains. So without that history or that understanding of the language, you forget that.

JW: You're just Ojibwe. Or whatever.
DC: You're just an Indian. And you feel like the Cree and (some word), meaning that you come from the four elements, and Elder Darcy (didn't catch this), he comes from the four directions, you go to the plains they say those four directions meant there was four elements that were brought together in order to (word) life. So there's that understanding that you will forget if you don't utilize the language.

JS: Yeah, I was looking at some quick stats - the stats are kind of old, they're from 2006 but just under 10\% of people, aboriginals living in Winnipeg actually know their language. Very low numbers considering you know, look at the Filipino community, right...
JW: How many people speak Tagalong here? It's the second behind French.

DC: Yep.

JS: Exactly. You have English, French, and then Tagalong. It's become really prevalent.

DC: It's because of their diaspora. Having to come to a different place meant it's their cultural imperative now to keep that language because they no longer have that connection to the Philippines. Whereas here...

JS: It was forcibly removed. 
DC: If it's gone, it's gone for good.

Except for the Ojibwe where we have a big huge colony of Germans who speak Ojibwe and they speak more (didn't catch it) they have fifty thousand acres over there.

JS: Really?

JW: Where's that? Cree Cree (didn't catch it)

[laughter]

JS: That's interesting.

DC: [laughs] No, we have that thing going on between us. Cree and Ojibwe.
JS: My next question you answered, is how Aboriginals today are able to relearn their forgotten language and you said through immersion...

JW: I think through immersion, yeah. I think one of Brian Bowman's election promises was to have an immersion program in Winnipeg.

\section{JS: Oh yeah?}

JW: ...wasn't it?

DC: Yeah.

JS: He's the new mayor?

JW: Yeah.
DC: Yeah. And just other ways; I know back, like, me and my cousins, there's like five of us and that can understand and readily speak Ojibwe. We're not fluent. My granny called us lazy speakers.

[laughter]

DC: And the ones from my parents' generation, they all speak and understand, but my nieces and nephews, not a word. So it's up to us, it's that imperative, your own personal responsibility to keep that language alive.

JS: Right. Not always relying on someone else. Taking that initiative I guess as well, right. 
JW: I think the only way it's going to happen is with a school system. It's like French.

DC: Not decolonize but recolonize ourselves in an either Cree or Anishinaabe way.

JW: Otherwise I think it's too English, it's too prevalent, it's too easy for kids. Every cartoon you watch or every game...

JS: Yeah. That's true.

DC: Although the (didn't catch it) are trying to make strides, they have that one Cree cartoon. I sit and listened to it and was like, oh my god, they're just

borrowing the big words.

[laughter]

JS: I come from two different backgrounds, Filipino and Punjabi. I know Punjabi really rudimentary, only because my grandparents don't speak English. I was not forced, but had to learn if I ever wanted to have that relationship with them. I'm afraid that my children, unless I marry an Indian woman, that it'll eventually be lost. Because if I know very little of it, it's just kind of a cascading type of thing, right? It's going to almost dilute itself. It has to be really saturated to begin with. And that saturation has to be continued.
JW: Right.

DC: $M m m ~ h m m$.

05:20

JS: How are aboriginal people educated on their rights and responsibilities regarding the treaties? Even the relationships with, let's say, The Hudson's Bay as a colonizer? I remember when I went to high school, we were taught some Canadian history, but it's the polished version you often read. It's not the ones that offer both narratives.

JW: Historically, it hasn't happened. But now we have an initiative called The Treaty Education Initiative. And we'll get you handouts. 
JS: Is it this thing right here?

JW: Yeah. We're basically, we started

in grades five and six, and we're creating resources for kindergarten to grade twelve, for teachers to integrate treaty education with social studies. So we're right now in over four hundred schools where they're using it, trained over a thousand teachers, and our long-term goal is to get every school fully integrated in Manitoba. So that every student leaving grade twelve can demonstrate an understanding of treaty and the treaty relationship.

JS: All right. Is that only prevalent in Manitoba or are other provinces taking part in being proactive?
JW: Saskatchewan.

DC: Saskatchewan.

JS: That's it, eh? Not BC?

DC: No.

JW: No.

DC: BC's a little different because they have only the Vancouver Island treaties, and they're just doing modern day treaties right now, except for maybe the Northern Eastern corner of $\mathrm{BC}$ which is treaty eight. So they really didn't have... a need for this. Where they do now, the BC treaty commission, they should start educating their province about the treaties that are there.

JW: And they're just starting talking about starting a commission in Alberta.

JS: You had a comment before...

07:15

DC: Yeah. I remember in high school and grade eleven history, the fur trade was done in one class only. It was just one class. And we went through twelve pages of a little handout, like ok, this is everything you need to know about the fur trade.

JS: Yeah, that's exactly it. I graduated in '96 and I just remember it being very brief, and it was over the course 
of a week that we learned about the interactions between Europeans and Aboriginals.

DC: I wonder if we still have those books. I remember there was a similar book, it was called 'Pre-History'. And that's where you learned about indigenous people. The very first class was the very first day is history. And after that, the fur trade. Second day, and after that, you jumped to... everything else.

JS: They really gloss over everything.

DC: So it was two days anything doing with indigenous people everything and everything else is just gone.
08:00

JS: It's really unfortunate. Where do mediation talks right now between the Crown and Aboriginal people take place? Is there a formal setting or is it only in Ottawa, let's say.

JW: Mediation talks? Is there any such thing?

JS: Yeah. Is there such thing?

DC: Well, the tribunal was supposed to be that, but again, it changed...

JS: Tribunal? What is that?

DC: It used to be called the Indian Claims Commission and is Indian Claims Tribunal now. It was just supposed to be specific claims and negotiating those treaty shortfalls.

\section{JS: Right.}

DC: And now it's just pushing out land claims. That's all it does now.

JW: And AFM does negotiate on behalf of First Nations but they're... They've been reined in even from doing that so they're not even really negotiating now. They're saying, "Here's a voice." But there's no actual mediation or anything going on that I know of. It's all happening in courts.

JS: I'm just trying to think, besides the legality of it, where do people come to speak? Is there an area where they 
can converge? Aboriginals and those related to the treaty can converge and talk about... I guess learn....

JW: Well, through our office is one venue but other than that...

JS: This office is.... It's not really a public kind of venue, right?

JW: Yeah

DC: Well, we have dialogues. They're usually invite.

JS: By invite?

DC: Through the parties who created us.
JS: Is it something that happens fairly often? I'm just trying to figure out how Aboriginal people learn about the treaties besides the school system. Is that the only kind of formal setting? Is there an informal setting?

JW: Facebook.

[laughter]

JS: Exactly. An informal setting where people can just come and talk?

DC: I think we're trying to create that space through our office.

JS: Because sometimes a formal setting can be intimidating at times. Are there alternatives to it? Everything being so formal and on the legal side.

\section{$11: 20$}

DC: I was saying, I really don't like the "Idle No More Movement". They would have treaty teachings at campuses or anywhere, like Polo Park. But before then, you would just have to learn from your own interest. Growing up in the community, I would hear other people talk about treaties and stuff like that and I was like, "What are you guys talking about?" And I would sit and listen.

JS: Mm hm. That's exactly what I'm talking about.

DC: So you're just really listening to what they would say. It's up to you. 
That's what it was before. It's up to you to go find out.

JS: I believe that if there's a discussion, it creates awareness. If it creates awareness, it creates more curiosity and you're going to look at it a bit more both on a public level and personal. I'm just trying to see if there's any informal place where people could come and talk about this or... secret place.

\section{$12: 02$}

DC: Well, what our office tries to do is we have what is called, "Brown Bag Lunch Series". We get people to come and talk about treaty issues, and people can come register and listen, or, if you're a speaker (words?), where if you have an interest, and you want a speaker, or a panel of speakers, we'll send them out to you. So we try our hardest to make sure that we get as many people, not just in schools, but outside schools.

JW: You only got about 5 more minutes.

\section{$12: 32$}

JS: Alright. I guess I'll ask another question then. How do you think architecture can play a role in being almost a vessel, or a voice for Aboriginal people? Using the Hudson's Bay, there was an example that was given by my advisor where in Detroit, a lot of the big house that were owned by whites, a lot of black people won't live in them. They won't live in a white person's house, right?

DC: Right, right. [laughter]

JS: That's the example he gave me. Even though these houses were dirt cheap, they just refuse to now. He was making the analogy to the Hudson's Bay Company; that you don't want to live in the house of the colonizer.

JW: Right.

JS: I'm just wondering how, if the building can be something of a positive for the Aboriginal community? 
JW: First Nations have taken over different residential schools. Some have refused to. And some have taken over residential schools, and have turned it around and said ok, we're gonna own this.

JS: Do you have an example off the top of your head?

JW: Umm... What's the community? Mont Plain?

DC: There's a residential school in Portage. They bought it and made it into a museum and office space.

JS: Really.
JW: Yeah.

JS: This is in Portage LaPrairie? I'll have to go down there.

14:00

DC: And they actually made a land claim down there, and they established a gaming centre, office space...

JW: Yeah, it's right off the highway.

JS: Is it? That's not far.

DC: Yeah, you can actually go in and take a look. They have monuments there to treaty, they have monuments there to residential school, traditional culture... So it's now kind of turning into an interpretive centre.

JW: There's one in BC that's quite famous, I can't remember the name of the reserve but, they did the same thing - offices complexes, a school, and they're doing quite well, this reserve, economically. I can't remember the name of it.

DC: Was that (some words)?

JW: No, there was a woman, and a Chief.

$14: 50$

DC: There's also that mentality too, that we have to sort of move away from as indigenous people. Do you remember that, where there was... 
by the fort Indians?

JS: By the?

DC: ... by the fort Indians.

JW: ...hanging around the fort.

JS: Oh, I've never heard that.

DC: It's kind of like where they're more dependant. It's a dependency model, whereas the other First Nation people were out hunting, fishing, trapping, gathering. We have some work to do in house as well.

JW: I think architecture can play a role. I'm not a big fan of the kind of the over-doer, like, symbols, and....

JS: Yeah. I found that talking to a lot of people, it's often over-embellished or something.

JW: Yeah, I'll give you an example. My community built a school in 1991. I've seen this happen all over reserves. The government will say, "We're funding you ten million dollars, twenty million dollars per school. $13 \%$ of your budget has to go to architecture." It's a significant amount of the total budget. The architects come in, they meet with the community, oh the four directions, the four colours, and they build these buildings... Where's some scrap paper... I'll show you our school.
The school at our reserve ended up built like this, right? So the doorway to the East, the South, the West, the North, gym is in the centre... You know it looks pretty cool. The four directions, each wing is a different colour... So it looks good?

JS: It's almost a cliché?

JW: Well, not only that but it's impossible practically wise. It absolutely sucks because if you got - so these are the hallways, this is the playground - it surrounds the school, if you want to supervise students, how many staff do you need?

JS: Right. 
DC: [laughter]

JW: So you need a person here, a person here, a person here, a person here... If you're outside you have a teacher here, kids hiding here, a teacher here, kids hiding here...

JS: It's just impractical.

JW: Totally impractical. Whereas you know, you had this old, ugly brick building, and it was only one floor, (missed word) you built schools over one floor. Here's the playground. You have one teacher's assistant that can stand right there and see the whole playground. Can see everything that's going on. You got hallways like this, you got one teacher that can see everything that's happening in the hallways. You've got all these schools that are designed now with curved hallways so you walk five feet and you can't see around the corner. And it may look cool, costs way more to build, and it's totally impractical. You got all these schools now, I was joking and saying that they're shaped like porcupines and crazy stuff, but they're totally impractical. But if you asked the architects, the architects feel good. 'Cause sometimes they'll win awards, right?

JS: It's that cultural reference, right?

JW: Mm hmm. It's like they're winning awards for useless buildings.
JS: So they're giving up a smart building for something that's cultural. They're not finding that balance.

JW: I wouldn't even say it's cultural. Sometimes it's force. It's too forced.

JS: Yeah, that's exactly it. I think force is the right word.

JW: When we did our school, they had the colours wrong.

[laughter]

JW: So they finished... 
APPENDIX Interview with Manitoba Treaty Commissioner James Wilson

Conversations with the

Commissioner:

Complete Transcript

Part 4
- along with Office Researcher Darren Courchene

Thursday December 18, 2014. 1340hrs.

Length: 00:05:13 (hh/mm/ss)

Treaty Relations Commission of Manitoba Office 400 - 175 Hargrave Avenue. Winnipeg, MB.

JW: ...so why is there black? They

Cree language, there's only blue!

used the Ojibwa colours?

00:05

JW: Why is there black? We don't use

black in our ceremonies. So they had to repaint the whole school. And then there's even within our communities, there's different, $y^{\prime}$ know, oh, that should be aqua blue, not this blue, but...

DC: Like, just make it blue! In the

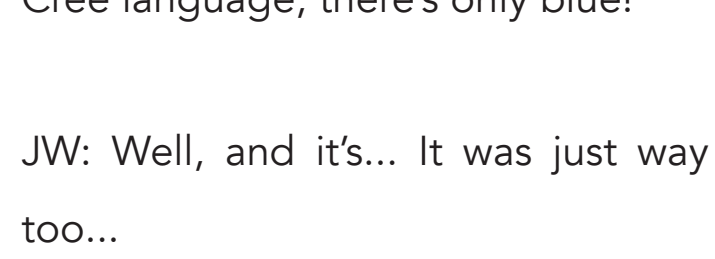
you look from on top, it looks like the 
shape of an eagle.

JW: It's a condor.

[laughter]

DC: That's what we joke about. It really doesn't look like an eagle!

[laughter]

DC: But that's how it was supposed to be designed. So now there's two hallways. They tried to make it as linear as they could because the others were like, same thing-a-majig, oh how many staff are you gonna have to make this circle building; to look at the kids, to watch over the kids. No, well make sure there's two hallways so you can have staff on both sides. And then you look at the circle of the thunderbird house here, they have that little motif that's supposed to look like a thunderbird coming out of a nest.

JS: Is that one on Main and Higgins?

DC: Yeah. And there's also the UBC building where the First Nations House, a longhouse, and I was like, a longhouse in BC? Like, couldn't you go with something a little more....

JS: More subtle?

[laughter]

DC: Yeah!

JW: Yeah. They have longhouses though...

DC: Yeah, but more towards highdubai. Not down south.

JW: Oh really? I didn't know that.

DC: Yeah. And then, who's running it the whole other thing...

02:05

JS:Itjustreminds me ofthatprecedent, that Expo '67, they used a pavilion. They were given some percentage of it to go towards architecture, they consulted aboriginal people, and what came out of it was just a giant tepee. Really, I don't want to say, tacky, but you know, people coming from around the world... It was almost 
like a gift shop or something.

JW: Yeah.
DC: Yeah.

JS: Just reading about that, I really like the precedence of how that they were almost slipping their narrative in there without... Like the Queen visited and it was short lived because of all the stores they had to put up. Basically saying, "This is what happened to our people; you stripped us of our voice." And one of the things it said on the wall was, "When you grow up aboriginal, the first thing you learn is English." It was their way of saying, "Hey, we want a voice. The architecture is a vessel." But the way they went about the architecture was very wrong.

JW: I don't know... I kinda haven't had a good impression of architects when we're working with First Nations, especially when we're building schools because the amount of waste I see.

\section{3:20}

DC: If they had elements that reflect how nature would be, I'm good with. Don't go, like, digging the whole four direction thing, or doing modelling after a longhouse, or like what they did with the Treaty Four Governance Centre, with a big tepee, and then all of a sudden there's a building jutting out on the side. I'm like, that doesn't look good either.
JW: Oh, FSIN?

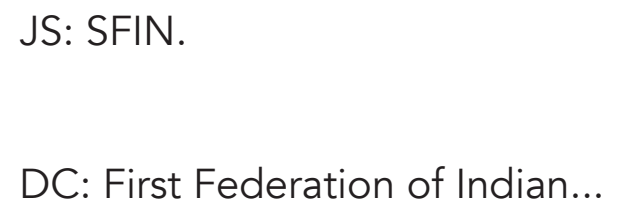

JW: Oh. I haven't seen that.

DC: It's in Fort Qu'Appelle.

JW: But FNUC has the same building, right? It's a tepee.

DC: We're Indian Affairs; we're looking for it now. But not everyone 
used the tepee.

JW: Yeah, you never see Inuit building a big igloo.

[laughter]

JW: They would say, "Why would we build a big, structural igloo?"

[laughter]

JS: That's totally true.

[laughter]

JS: Great! Thank you very much for your time, I really appreciate this.

JW: Yep!

DC: Yep! Take a look at the Museum of Indian History down south.
JS: Sorry?

DC: The Museum of Indian History, go take a look at it.

JW: The one in Washington.

JS: Is that the one designed by Douglas Cardinal?

DC: $M m h m m$.

JS: They have their firm in Ottawa.

DC: Take a look at it. Now that is architecture.

JS: I heard it was really good. Umm, I guess I'll get you to just add on to here.
DC: Is this the recording?

JS: Yeah.

DC: I give oral consent to.... What's your name again?

JS: Jag Singh

DC: ...to Jag Singh to utilize my voice in his interview.

JW: You're not gonna write it? Make it a political statement? Are we gonna be like that?

DC: Oh my god, ok ok...

[laughter] $\infty$ 

POST-SCRIPT

What this Thesis has Taught Me:

Final Thoughts and Responses
"Why is the conservation of The Hudson's Bay Company department store of importance to the city of Winnipeg, but more importantly for Canadians?" It was soon realized that it was not just about saving a building, but architecture serving a social role - a voice for a community.

Before architecture played had come to be, or in the very least a role in my life - some time ago - I had the opportunity to work as a Correctional Officer at the Winnipeg Remand Centre where the Aboriginal inmate population fluctuates between 70 to 80 percent at any given time. Consequently, my interactions and views regarding Aboriginals for the most part had been extremely judgmental, if not negative. I failed to see the problem regarding Aboriginals and how things acknowledge them. For me, it had become more of a nuisance.

Commencing these thesis investigations, the subject in question was: "Why is the conservation of The Hudson's Bay Company department store of importance to the city of Winnipeg, but more importantly for Canadians?" I soon realized that it was not just about saving a building, but architecture serving a social role a voice for a community. 
My initial research on the subject had already confirmed what I thought I knew about the subject: if The HBC had not contributed so much to the nation's development, we would not be where we are today. This is true, except I was in actuality only realizing but one fragment of this skewed narrative.

Furthering my investigations, I was dumbfounded on how biased my views were concerning Aboriginals, their narrative, and their plights. How one-sided the educational system had been in the past; including how pop-media portrays the Aboriginal community.
From this, other questions and themes emerged, one of which was how much people either knew about Aboriginal's and their narrative, or how they did not; and the distance between either ends of this spectrum, not only encompassing the majority of Canadians, but the size of this gap that became important.

This gap, for me, deeply translated into how Canadians view or relate themselves as having some sort of Aboriginal values and beliefs; Canadians often tend to think their views are mainly shaped by either the English or French for the greater part. Learning what it means to be a Canadian can only be done by carefully by accepting Aboriginals as an influential pillar of our nation, including their narrative, struggles and values. As an English-French bilingual myself, and having lived the larger part of my life in Winnipeg, I am very reluctant to say that I have not taken advantage of, or the initiative to learn about this third pillar of Canada. I believe many Canadians do still have a hard time identifying themselves and what it means to be Canadian, mainly because we do not spend enough time fully learning where we as a Nation have come from. Knowing who you are, starts with knowing where you came from. 
Following the introduction of the idea of an Aboriginal Embassy,

it consequently opened up many more discussions and questions, ranging from the conservation of the actual HBC edifice, what benefits does the HBC might gain from the implementation of an Embassy, the multitude of political precedents, and a range of other possibilities on how the architectural intervention may have been executed. As noted by Nathen Jensen in Constructed Histories: Storytelling and the Practices of Architectural Conservation: "A building can be conserved only through the understanding and employment of its own heterogeneous story, one that endures in and through its plurality of meanings, and transcends any particular moment in its own accumulated history."1 Basically, Jensen is stating that the conservation of buildings is not mandated by the singularity of one or even two forces, but should be primarily driven by its core.

Though the notion of an AboriginalEmbassy can beconsidered somewhat of a recent development, there have been similar notions put forth in the past by similar groups and communities wanting to push their agendas to gain recognition for their distinct cultural uniqueness.
Extremist parties such as the Front de Libération du Quebec (FLQ), which have been known for violent acts in the early 1960s in Canada to bring recognition to their political agenda; the Quebec referendums throughout the 1980s and 90s; as well as Quebec's own political embassies dispersed across the globe have all been strategies in which Canada's own French community have used to highlight their distinct cultural significance within a predominant British colony. It is no surprise then that the Aboriginal community then does not have their own distinction. The audacious and provocative move of introducing a red band along the 
exterior of the top 6th floor of The HBC

store was well received by critiques.

Its subtle yet powerful gesture is anticipated to resonate stronger that some of the more obvious ones; a theme that may well be implemented throughout the entire Aboriginal Embassy. Regardless of various iterations that may or could have been introduced, the point is clear: the Aboriginal narrative needs to be heard, and architecture must serve as a catalyst if it is to serve any purpose at all beyond the basics of providing protection against the elements. That is, in this thesis, architecture as a vessel and a voice for a silenced community. $\infty$

Endnotes.

01. Jensen, Nathen. Constructed Histories: Storytelling and the Practices of Architectural Conservation. Abstract. Master of Architecture Thesis. Carleton University. 2009. Print. p. ii. 



\section{BIBLIOGRAPHY}

Artibise, Alan F.J. Historica Canada. Website. Cities and Populated Places: Winnipeg. http:// www.thecanadianencyclopedia.ca/en/article/ winnipeg/

Auld, Abigail. WPGxHBC. Website. www. wpgxhbc.com

Babad, Michael. The Globe and Mail. website. How Starbucks Has Conquered Canada. May 27 2014. http://www.theglobeandmail.com/reporton-business/top-business-stories/how-starbuckshas-conquered-canada/article18865907/

Carter, Graydon. The Hudson's Bay Company. New York. U.S.: Assouline Publishing. 2011. Print.

The City of Winnipeg. Our Winnipeg: It's Our City, It's Our Plan, It's Our Time. Winnipeg, MB. 2011. Print.

The City of Winnipeg. Website. http:// www.winnipeg.ca/services/CityLife/ HistoryOfWinnipeg/HistoricalProfile.stm

Dafoe, Christopher. Winnipeg: Heart of the Continent. Winnipeg, MB: Great Plains Publications, Ltd. 1998. Print.

Daschuk, James. Clearing the Plains: Disease, Politics of Starvation, and the Loss of Aborigina Life. Regina, SK: University of Regina Press. 2013.

The Exchange District. Website. Historic Exchange. http://www.exchangedistrict.org/ tours-attractions/historic-exchange/
The Forks. Website. The Forks 6000 Years Ago. http://www.theforks.com/about/history

Gourluck, Russ. Going Downtown: A History of Winnipeg's Portage Avenue. Winnipeg, CA: Great Plains Publications. 2006. Print.

Government of Northwest Territories. Aboriginal People and the Crown: A Changing Relationship. Introduction. PDF document. http://www.gov. nt.ca/publications/asg/pdfs/abor.pdf

HBC Archives. Website. www.gov.mb.ca/chc/ archives/hbca/about/hbca_holdings.html

The Hudson's Bay Company Heritage. Website. http://www.hbcheritage.ca/

Jensen, Nathen. Constructed Histories: Storytelling and the Practices of Architectural Conservation. Master of Architecture Thesis. Carleton University. 2009. Print.

Manitoba Hydro. Website. Building Facts. http:// www.hydro.mb.ca/corporate/mhplace/quick facts_building.shtml

Monteyne, David P. The Construction of Building + Histories: Hudson's Bay Company Department Stores, 1912-1926. MArch thesis History/Theory Program UBC, 1995. Print.

MTS Centre. Website. Quick Facts. http://www. $\mathrm{mtscentre.ca/mts-centre-information/quick-facts}$ 
Macdonald, Nancy. Welcome to Winnipeg: Where Canada's Racism Problem is at its Worst. Maclean's Magazine. February 02, 2015. Toronto, ON: Rogers Publishing Ltd. 2015. Print

Manitoba Provincial Archives. HBCA Holdings. Website. www.gov.mb.ca/chc/archives/hbca/ holdings/special_media.html\#cartographic

Newman, Peter C. Empire of the Bay: An Illustrated History of the Hudson's Bay Company. Toronto, ON: Madison Press Books. 1989. Print.

The National Film Board of Canada. The Other Side of the Ledger: An Indian View of the Hudson's Bay Company. Film. 42 mins 22 secs. 1972. https:// www.nfb.ca/film/other_side_of_the_ledger

The National Research Council. The Embassy of the Future: Recommendations for the Design of Future U.S. Embassy Buildings. Washington, DC: National Academy Press. 1986. Print.

PBS. Website. Empire of the Bay: Introduction Retrace the Steps of the Hudson's Bay Company's History. www.pbs.org/empireofthebay/timeline/ intro.html

Ray, Arthur J., Jim Miller, And Frank Tough. Bounty and Benevolence: A History of Saskatchewan Treaties. Montreal, QC: Mc Gill-Queen University Press. 2000. Print.

Saul, John Ralston. A Fair Country: Telling Truths About Canada. Toronto, CA: Penguin Canada. 2008. Print.
Searle, Ronald and Kildare Dobbs. The Great Fur Opera: Animals of The Hudson's Bay Company 1670-1970. Toronto, ON: Mc Clelland and Stewart Limited. 1970. Print.

Shilliday, Gregg. A History of Manitoba: Volume One - Rupert's Land to Riel. Winnipeg, MB: Great Plains Publications, Ltd. 1993. Print.

Shilliday, Gregory. A History of Manitoba: Volume Three - Decades of Diversity. Winnipeg, MB Great Plains Publications, Ltd. 1995. Print.

Statistics Canada. 2012. Winnipeg, Manitoba (Code 4611040) and Division No. 11, Manitoba (Code 4611) (table). Census Profile. 2011 Census. Statistics Canada Catalogue no. 98-316-XWE. Ottawa. Released October 24, 2012. http:// www12.statcan.gc.ca/census-recensement/2011/ $\mathrm{dp}-\mathrm{pd} / \mathrm{prof} /$ index.cfm?Lang $=\mathrm{E}$

Turner, Randy. Winnipeg Free Press. Website. City Beautiful: How Architecture Shaped Winnipeg's DNA. Part 1: Great Expectations. http://www.winnipegfreepress.com/citybeautiful/City-Beautiful---Part-1-GreatExpectations-273837201.html 
